GÖTTINGER ZENTRUM

FÜR BIODIVERSITÄTSFORSCHUNG UND ÖKOLOGIE

- Göttingen Centre for Biodiversity ANd ECology -

\title{
LATE QUATERNARY VEGETATION HISTORY AND CLIMATE CHANGE IN THE GOBI DESERT, SOUTH MONGOLIA
}

\author{
Dissertation zur Erlangung des Doktorgrades der \\ Mathematisch-Naturwissenschaftlichen Fakultäten der \\ Georg-August-Universität Göttingen
}

vorgelegt von

Waheed Murad

(M.Phil.)

aus

Dargai, Pakistan

Göttingen, June, 2011 


\title{
LATE QUATERNARY VEGETATION HISTORY AND CLIMATE CHANGE IN THE GOBI DESERT, SOUTH MONGOLIA
}

\author{
By
}

Waheed Murad

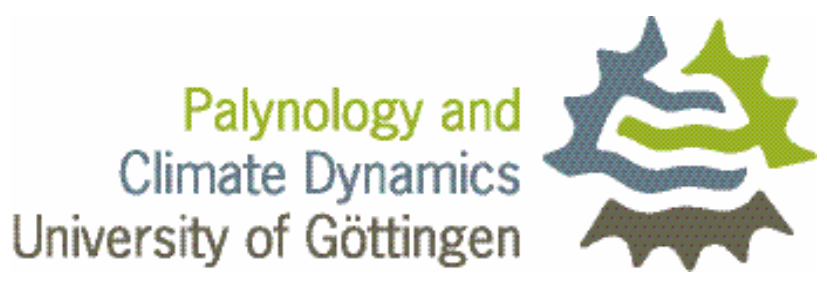

The Dissertation is submitted to Albrecht-von-Haller-Institute for Plant Sciences, Department of Palynology and Climate Dynamics in partial fulfillment of the requirements for the degree of DOCTOR OF PHILOSOPHY

In BIOLOGICAL DIVERSITY AND ECOLOGY
Albrecht-von-Haller-Institute for Plant Sciences, Department of Palynology and Climate Dynamics, Göttingen Centre for Biodiversity and Ecology (GCBE), University of Göttingen, Germany 


\title{
Supervisory Committee:
}

Supervisor: $\quad$ Prof. Hermann Behling

Albrecht-von-Haller-Institute for Plant Sciences

Department of Palynology and Climate Dynamics

University of Göttingen,

Untere Karspüle 2

37073 Göttingen, Germany

\section{Co-supervisor 1： Prof. Markus Hauck}

\author{
Albrecht-von-Haller-Institute for Plant Sciences \\ Department of Ecology and Ecosystem Research \\ University of Göttingen, \\ Untere Karspüle 2 \\ 37073 Göttingen, Germany
}

\section{Co-supervisor 2: Dr. Frank Schlütz}
Albrecht-von-Haller-Institute for Plant Sciences
Department of Palynology and Climate Dynamics
University of Göttingen,
Untere Karspüle 2
37073 Göttingen, Germany 


\section{Dedication}

\section{I dedicate my research work to}

\section{- My parents}

I can't repay the lessons that you taught when I was small

Or give you gift for gift the daily treasures I recall

I can't return encouragement and loving words of praise In quite the way you did for me through all my childhood days But there is one gift that I can give., it's all the love you've earned For love is what you always taught. And love is what I learned.

\section{- My uncles and my cousins}

Abdul Rauf, Said Bacha, Nowsherawan, Muhammad zahir and Arshad iqbal who are no more alive to see me prosperous. I shall say for them; everything that has a beginning has an ending. ALLAH keeps their souls in peace and hope that all will be well at their eternal lives

$\begin{array}{lcccccr}\text { You } & \text { never } & \text { said } & \text { we } & \text { are } & & \text { leaving } \\ \text { you } & \text { never } & \text { said } & \text { good } & \text { bye } & \\ \text { you } & \text { were } & \text { gone } & \text { before } & \text { I } & \text { knew } & \text { it } \\ \text { and } & \text { only } & \text { ALLAH } & \text { knew } & \text { why }\end{array}$




\section{Table of Contents:}

Title

Page No

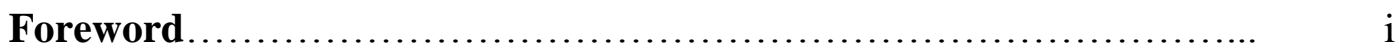

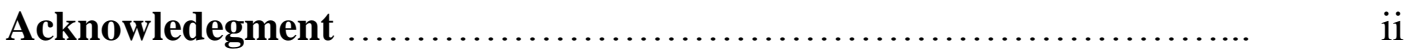

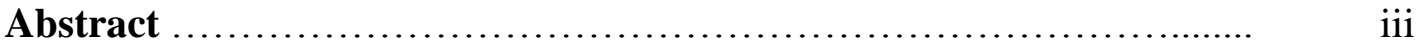

\section{Chapter 1 - General Introduction}

1.1. Palaeo-climate research background ..................................... 1

1.2. Research goals and study outline ............................................ 2

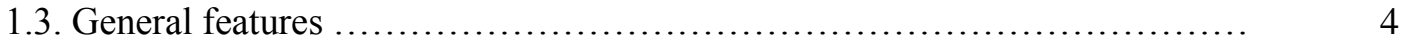

1.3.1. Location........................................................ 4

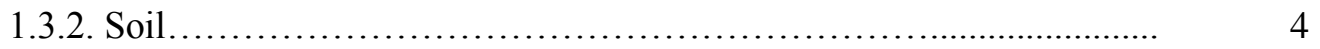

1.3.3. Water resources.................................................. 4

1.3.4. Climate ..............................................................

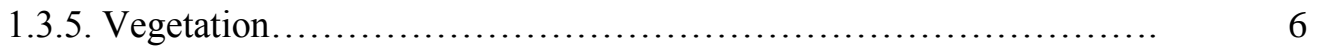

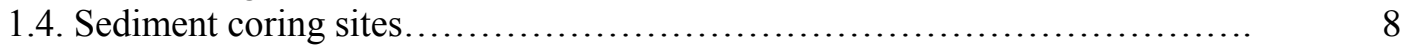

1.5. Materials and methods ….......................................................

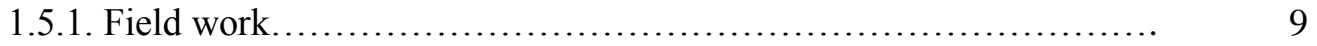

1.5.2. Laboratory work ...................................................

1.5.3. Radiocarbon dating..............................................

1.5.4. Identification of pollen and spores................................... 10

1.5.5. Data presentation....................................................

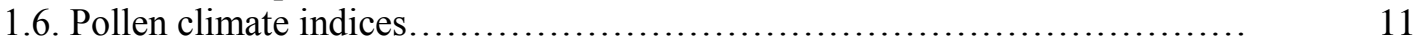

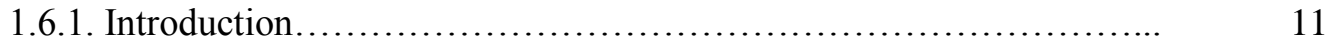

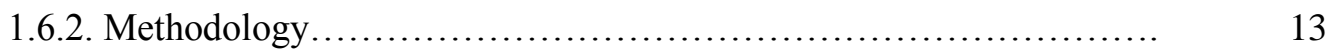

1.6.3. General interpretation............................................

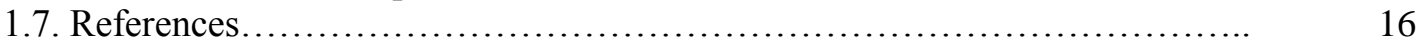

Chapter 2 - First high resolution palynological record of climate history in the late Quaternary from the high continental Gobi desert of Mongolia (Manuscript 1) ................................................................ 21

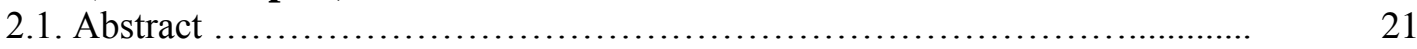

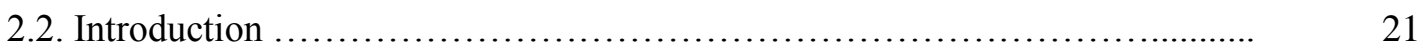

2.3. Modern climate and vegetation ........................................... 23

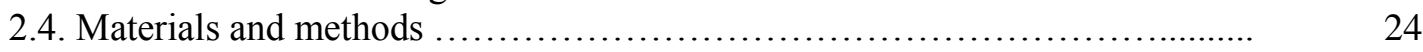

2.5. Stratigraphy and chronology ............................................. 25

2.6. Results and interpretation................................................... 26

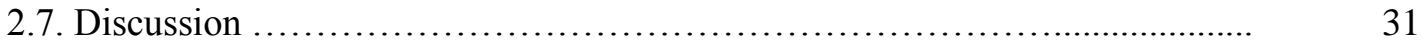

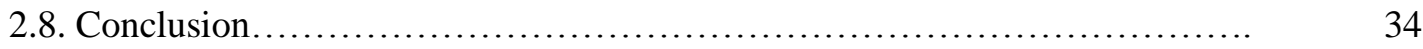

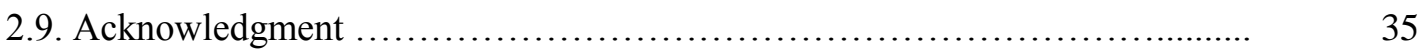

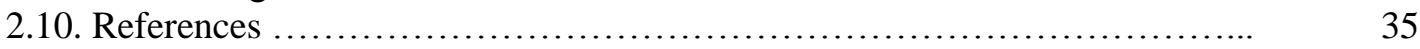

Chapter 3 - Late Quaternary climate and landscape evolution in arid Central Asia: A multiproxy study of lake archive Bayan Tohomiin Nuur, Gobi desert, southern Mongolia (Manuscript 2) 


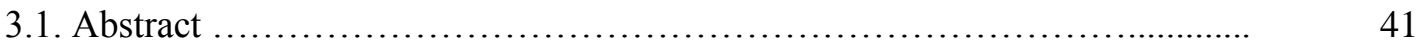

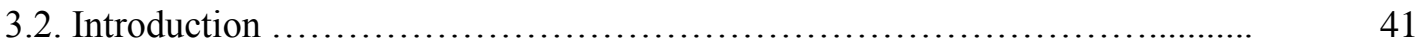

3.3. Regional setting ................................................. 42

3.4. Materials and methods .............................................. 44

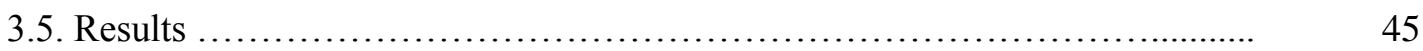

3.5.1. Chronology .............................................. 45

3.5.2. Sediment analysis ........................................ 47

3.5.3. Palynological and ostracod analysis .......................... 50

3.6. Discussion ........................................................ 51

3.6.1. Core interpretation ...................................... 55

3.6.2. Paleoclimatic implications .................................. 56

3.7. Conclusion ...................................................... 59

3.8. Acknowledgment .................................................... 59

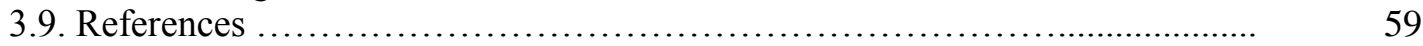

Chapter 4 - High resolution pollen record from lake Orog Nuur, southwestern Mongolia: An evidence for climate change based on

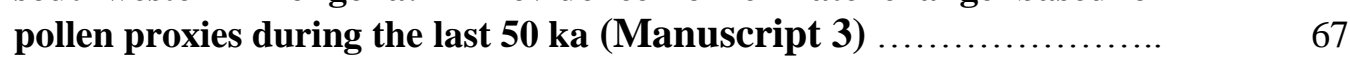

4.1. Abstract............................................................ 67

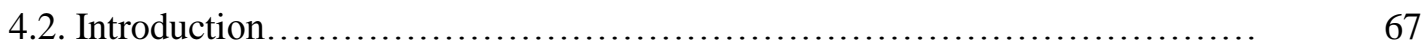

4.3. Regional setting................................................... 68

4.4. Materials and methods................................................ $\quad 72$

4.5. Chronology ..................................................... 73

4.6. Results and interpretation........................................ 73

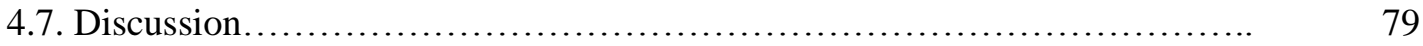

4.8. Conclusion ..................................................... 81

4.9. Acknowledgment.................................................... $\quad 82$

4.10. References....................................................... 82

Chapter 5 - Supplementary studies: Olgoy Nuur (unpublished)

Vegetation and climate history of Olgoy Nuur, Central Mongolia during late

Glacial to Holocene based on pollen records................................

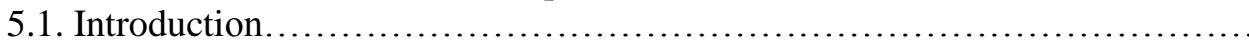

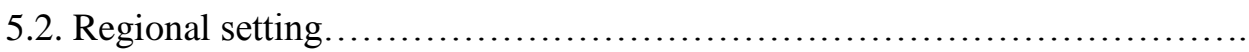

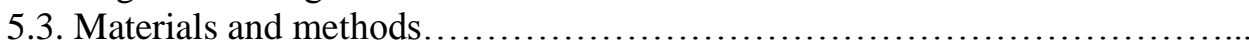

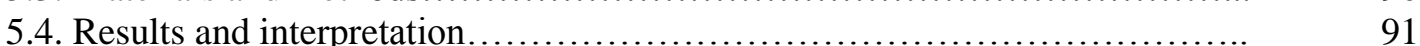

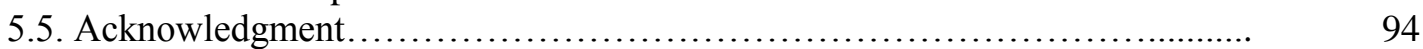

5.6. References......................................................... 94

\section{Chapter 6 - Supplementary studies: Pollen Key (unpublished)}

Master key for pollen grain identified from Bayan Tohomiin Nuur, Orog Nuur and Olgoy Nuur, South Mongolia.

Chapter 7 - Synthesis................................................... 103

Appendix I: List of identified pollen, fungal spores, fern spores, algae and zoological remains......................................... 107

Appendix II: Complete list of pollen and spores diagrams.................... 119 
Fig. 1.1A: $\quad$ Picture showing Chenopodiaceae desert in the surrounding of BTN 7

Fig. 1.1B: $\quad$ A common plant member of Chenopodiaceae in the study area $\quad 7$

Fig. 1.2A: $\quad$ Collection of sediment samples from BTN 9

Fig. 1.2B: $\quad$ Collection of sediment samples from ONW 9

Fig.1.3: $\quad$ Grouped pollen percentages of the six pollen groups (S1-S6) from BTN

$\begin{array}{ll}\text { core used in the calculation of pollen-climate indices } & 14\end{array}$

Fig.1.4: $\quad$ Grouped pollen percentages of the six pollen groups (S1-S6) from

ONW sediment samples used in the calculation of pollen-climate indices $\quad 14$

Fig.1.5: $\quad$ Temperature and moisture indices based on BTN sediment samples $\quad 15$

Fig. 2.1: $\quad$ Map of Mongolia with investigation site and sites mentioned in the text 22

Fig. 2.2: $\quad$ Age-depth model of the Bayan Tohomiin Nuur site based on a

$\begin{array}{ll}\text { polynomial graph } & 27\end{array}$

Fig. 2. 3: $\quad$ Pollen and non pollen palynomorphs percentage diagram of BTN 28

Fig. 3.1: $\quad$ Location of the Bayan Tohomiin Nuur 43

Fig. 3.2: $\quad$ Age-depth model of the core Bayan Tohomiin Nuur based on a

$\begin{array}{ll}\text { polynomial graph } & 47\end{array}$

$\begin{array}{lll}\text { Fig. 3. 3: } & \text { Results of the grain size analysis } & 48\end{array}$

Fig. 3.4: $\quad$ Sedimentological proxies of the Bayan Tohomiin Nuur core 49

Fig. 3.5: $\quad$ Palynological proxies in percentages, ratio, concentration and

$\begin{array}{ll}\text { absolute ostracod abundances } & 50\end{array}$

Fig. 4. 1: Map of Mongolia with investigation sites mentioned in the text 69

Fig. 4. 2: $\quad$ Map of Mongolia showing the investigation site of our study 71

$\begin{array}{lll}\text { Fig. 4. 3: } & \text { Age-depth model of lake Orog Nuur } & 74\end{array}$ 
Fig. 4. 4: $\quad$ Pollen and non pollen palynomorphs percentage diagram of Orog Nuur

Fig. 5.1: $\quad$ Pollen and non pollen palynomorphs percentage diagram from Olgoy Nuur

\section{List of tables}

\section{Page No}

Tab. 1.1: $\quad$ Results of the AMS ${ }^{14} \mathrm{C}$-datings of BTN and ONW and their calendric age-conversion (calibration) with $1 \sigma$ standard deviation (SD)

Table 1.2: $\quad$ Selected pollen taxa in the pollen groups (S1-S6) used in the calculation of the pollen ratios which were ultimately used for the calculation of temperature index (T) and moisture index (M)

$\begin{array}{ll}\text { Tab. 2.1: } \quad \text { Results of the AMS }{ }^{14} \text { C-datings } & 25\end{array}$

Tab. 2.2: $\quad$ Synopsis of vegetation, landscape and climate evolution at the BTN

Tab. 3.1: $\quad$ Results of the AMS ${ }^{14} \mathrm{C}$-datings

Tab. 3.2: $\quad$ Summary of the reconstructed climatic and environmental changes in

BTN area

Tab. 4.1: $\quad$ Results of the AMS ${ }^{14}$ C-datings $\quad 73$

Tab. 4. 2: $\quad$ Synopsis of vegetation and climate evolution at Orog Nuur 80

Plate 1-6: $\quad$ Showing pollen, fungal spores, fern spores, algae, zoological remains and unknown taxa 


\section{Foreword}

The compilation of this thesis represents my $\mathrm{PhD}$ studies at the Albrecht-von-Haller-Institute for Plant Sciences, Georg-August University of Göttingen, Germany. The research work was carried out at the Department of Palynology and Climate Dynamics for the award of PhD degree in Biological diversity and Ecology for consecutive three years since June, 2008 to May, 2011. The project was completed under the supervision of Dr. Frank Schlütz, Prof. Hermann Behling and Prof. Markus Hauck.

The research work is a collaborative part to the project "Late Pleistocene, Holocene and ongoing Geomorpho-dynamics in the Gobi Desert., South Mongolia" under the supervision of Prof. Frank Lehmkuhl, RWTH Aachen (LE 730/16-1). The project was mainly funded by German Research Foundation (Deutsche Forschungsgemeinschaft, DFG). The Higher Education Commission (HEC) of Pakistan and Kohat University of Science and Technology, Kohat (KUST), Pakistan funded my three years scholarship including the AMS radiocarbon dating and palynological analysis of the project. The Mongolian Academy of Sciences (Prof. D. Dorjgotov, A. Tschimegsaichan) extended help during the field work to the visiting team (Prof. Frank Lehmkuhl, Dr. Frank Schlütz and Dr. Thomas Felauer).

The compilation of this dissertation is based on the present synthesis and the following three manuscripts.

1. Murad, W., Schlütz, F., Felauer, T., Mischke, S., Lehmkuhl, F. (submitted). First high resolution palynological record of climate history in the late Quaternary from the high continental Gobi desert of Mongolia.

2. Felauer, T., Schlütz, F., Murad, W., Mischke, S., Lehmkuhl, F. (2012). Late Quaternary climate and landscape evolution in arid Central Asia: A multiproxy study of lake archives Bayan Tohomiin Nuur, Gobi desert, southern Mongolia. Journal of Asian Earth Sciences.

3. Murad, W., Schlütz, F., Felauer, T., Mischke, S., Lehmkuhl, F. (in preparation). High resolution palynological record from lake Orog Nuur, southwestern Mongolia: An evidence of climate history during the last $50 \mathrm{ka}$.

All the results of the research work are presented in the above three manuscripts which are supported by the relevant tables and figures.

I hereby certify that I, as a co-author of the manuscript 2 carried out the pollen laboratory work, microscopic study, pollen data analyses, interpretation and discussion. I also produced the figures and the tables for the manuscript where necessary. 


\section{Acknowledegment}

First and foremost all praises to Almighty, All Gracious, All Compassionate "ALLAH" who blessed me to complete this project. I owe my sincere thanks to my supervisor Prof. Hermann Behling, Department of Palynology and Climate Dynamics, Göttingen for his friendly attitude and constant guidance throughout the duration of my research task.

I would like to express my deep and sincere gratitude to Dr. Frank Schlütz, Department of Palynology and Climate Dynamics, Göttingen whose constant encouragement, guidance, support and fruitful discussions from the initial to the final level enabled me for the successful completion of the project.

I also offer my regards to Prof. Markus Hauck, Department of Ecology and Ecosystem Research, Göttingen for his assistance as co-advisor.

I am grateful to Thomas Felauer, Department of Geography, RWTH Aachen University, Germany for his continuous assistance in writing the manuscripts regarding the section of geochemical analysis.

I wish to express my thanks to Prof. Steffen Mischke, Institute of Earth and Environmental Science, University of Potsdam, Germany for his contribution in Ostracod data and fruitful comments for the improvement of the manuscripts.

Special thanks to all my graduate colleagues especially Dr. Jörg Christiansen, Dr. Vivian Jeske-Pieruschka, Isabelle Matthias, Lyudmila Shumilovskikh and Barbara Hermanowski for sharing their computer knowledge and invaluable assistance to achieve this goal. Despite their hectic schedule, they have always been a constant source of encouragement during my doctoral study. I especially admire the persistent and meticulous attitude of Dr. Jörg Christiansen.

I wish to express my warm and sincere thanks to Ulla Grothmann and Uta Nüsse-Hahne for providing support during the laboratory work.

I also offer my best regards to Prof. Lutfullah Kakakhel, Vice chancellor, Kohat University of Science and Technology, Kohat (KUST), Pakistan. Without his assistance and support, my ambition to study abroad can hardly be realized. He gave me encouragement during my difficult moments. His sincere advice and friendly help enabled me to have the document in the present shape.

The author would like to convey thanks to the Higher Education Commission (HEC) and Kohat University of Science and Technology, Kohat (KUST), Pakistan for the grant of scholarship.

It is an honor for me to express my love and gratitude to my parents, brothers, sisters and all beloved family members; for their moral support and endless love throughout the duration of my studies. I have no suitable words to express my feelings and can fully describe everlasting love of my parents to me. I pay salute to my parents and pray that I may extend every possible help which they need throughout the rest of my life.

I owe my loving thanks to my wife and my son Sayed Muhammad Aayan. They suffered a lot due to my research abroad. It would have been impossible for me to finish this study without the encouragement and mutual understanding of my wife.

Lastly, I owe my deepest gratitude to all of those who supported me in any respect during my doctoral study. 


\begin{abstract}
Southern Mongolia is a part of the arid to semiarid region of Central Asia and represents a transitional zone between the circulation systems of westerlies and associated North Atlantic Oscillation (NAO), the Asian summer monsoon and the Mongolian High Pressure System (MHPS). The sedimentary records from this geographically important region are a central key to understand past vegetation and climate changes, owing to variations in the intensity of the interacting climate systems. It is imperative to understand the palaeoclimate dynamics and landscape development of arid Central Asia based on past vegetation history and to get a notion about the future environmental conditions under the ongoing Global change.

The available palaeo-vegetation and palaeo-climate data from arid Central Asia are mainly conducted in Northwestern Mongolia and Northwestern China. The present research work focus on palaeo-ecological analyses of two lake archives of southern Mongolia (Bayan Tohomiin Nuur and Orog Nuur). The multidisciplinary analyses of these two sediment cores were carried out to reconstruct lake level changes, palaeo-vegetation and palaeo-climate dynamics and to expose the associated influencing biotic or abiotic factors during the last 50 kilo calibrated years before present (50 ka cal BP). Palynological and geochemical analyses of the Bayan Tohomiin Nuur revealed a detailed history of vegetation and landscape dynamics in continental Central Asia from 15 to $4 \mathrm{ka}$ cal BP. The reconstructed arid climate phases between 12.3- 11.1 and 8.6- 7.6 ka cal BP can be correlated to the Younger Dryas and the 8.2 ka event respectively. Stable and relatively moist conditions occurred in the mid-Holocene from 6.3 to $4.9 \mathrm{ka}$ cal BP. A mid-Holocene climate moisture maximum is attributed to the strengthening of the westerlies. However, the combined influence of the westerlies and summer monsoon caused a quite humid phase just before the Holocene climate optimum, while bordering areas in north and south of the investigation area were dry. The aridity in southern Mongolia increased after $3.8 \mathrm{ka}$ cal BP as inferred from the geochemical record of the lake archive. The palynological study from the sediments of Orog Nuur show reconstructed vegetation and climate history during the last $50 \mathrm{ka}$. Generally semi humid conditions prevailed between 49.5 and $44.7 \mathrm{ka} \mathrm{cal} \mathrm{BP}$, correlating to Marine Oxygen Isotope stage 3 (MIS 3). It is followed by relatively a dry and cool climate from 44.7 to $23.2 \mathrm{ka}$ cal BP corresponding to Marine Oxygen Isotope stage 2 (MIS 2). The increase in the concentration of green algae Pediastrum and Botryococcus indicate increase in semi arid conditions between 23.2 and $22.7 \mathrm{ka}$ cal BP. The aridity of the climate increases since $18.9 \mathrm{ka}$ cal BP till the onset of early Holocene. Our findings indicate continuous climate oscillations during the documented period of about $50 \mathrm{ka}$. Generally desert or desert steppe vegetation is prevailing as indicated by Artemisia, Chenopodiaceae and Ephedra.

Our findings show a general consistence to the palaeoclimate data with the surrounding regions of Central Asia. However, further multidisciplinary studies of palaeo-vegetation and palaeo-climate archives from the continental southern Mongolia are emphasized to gain a deeper understanding of the past environmental changes and to decode the complex spatial pattern of climate history of arid Central Asia during the late Quaternary. Such multidisciplinary approach will provide a base to understand the predictions for future environmental changes and will contribute information for nature conservation.
\end{abstract}




\section{Chapter 1 \\ General Introduction}

\subsection{Palaeo-climate research background}

Mongolia is presenting a wide variety of terrestrial and aquatic habitats. It retains a substantial amount of its natural biodiversity. Two of the world's most biologically outstanding eco-regions, the Daurian steppes and the Altai-Sayan Mountains, lie partly within Mongolia (Bedunah et al., 2006). The country boasts centuries old tradition of nature conservation using protected areas (Johnstad and Reading, 2003). Mongolia is vulnerable to climatic extremes and variability with severe droughts. Climate change is observed at a pronounced pace in some regions of the globe (Chase et al., 2000) where as Gobi desert is climatologically very sensitive to future global change (Batima and Dagvadorj, 1998). Global change studies from the area observed a particularly high increase of temperature during the late $20^{\text {th }}$ century and predict a further high increase of temperature in the $21^{\text {st }}$ century (Dulamsuren et al., 2010). Summer temperature is projected to increase by $2{ }^{\circ} \mathrm{C}$ and winter temperature by $1{ }^{\circ} \mathrm{C}$ within the next 80 years (Sato and Kimura, 2006). Mongolia's mean annual temperature is increased by $1.8{ }^{\circ} \mathrm{C}$ over the last 40 years. This is more than twice the global average increase of $0.7{ }^{\circ} \mathrm{C}$ during the past 100 years (Batima, 2006; Trenberth et al., 2007). The late $20^{\text {th }}$ century warming in Mongolia has already resulted the melting of glaciers (Kadota and Davaa, 2005). The rising temperature and uncertainties in precipitation intensity as well as duration associated with a changing climate are likely to increase the impact of climate variability and extremes (Nandintsetseg et al., 2007).

Relatively little is known about the long-term vegetation and climate history of the area or the relative impact of changes in land use, vegetation and climate in the region (Shinneman et al., 2010). The available palaeo-vegetation and palaeo-climate records from Mongolia are reported very recently (Jacoby et al., 2003; Nandintsetseg et al., 2007). These studies have revealed substantial differences in the availability of past moisture. The palaeo-climate records from arid Central Asia show substantial, temporal and spatial variability in the correlation between temperature and moisture availability. The climate models are inconsistent in predicting for future climate warming (Shinneman et al., 2010). Understanding regional vegetation and climate variability on spatial and temporal scales is important both for human and economic development. A better assessment of regional climate variability in Mongolia can reveal the range of climatic conditions experienced during Holocene. Such data can aid in resource management as well as contribute to a greater scientific understanding of such a climatologically unique area. This thesis contributes new proxy records of past ecological and climatic characteristics of the Gobi Altai and Gobi desert during the late Quaternary period. This improved multidisciplinary effort will lead to a better understanding of Central Asian vegetation and climate variability of the past and the underlying forcing mechanisms for vegetation and climate change. The current synthesis will also help to detect the future global changes and conservation managements. 


\subsection{Research goals and study outline}

Mongolian plateau is very important for palaeo-vegetation and palaeo-climate data due to variations in the intensity of the Mongolian High Pressure System (MHPS) which has a strong control on the regional climate of Central Asia. The MHPS drives strong westerly wind system especially in Gobi desert and have reported to occur throughout Quaternary times (Owen et al., 1997). The region has very diverse and extreme continental vegetational and climatic conditions with steppe, dry steppe and desert regions and well forested Khangai, Khentein and Khuvsgul mountainous areas. The mean annual precipitation values are about 300-400 mm (occasionally exceeding 600). The mid-latitude westerlies affect the northwestern part of Central Asia and bring moisture to the western mountain ranges of southern Mongolia (Lehmkuhl and Haselein, 2000).

Interdisciplinary data collection on vegetation and climate change during the late Pleistocene and Holocene has been a focus of attention to understand the regional climatic variability. Although abrupt vegetation and climate changes during the late Quaternary period have been documented in northern Mongolia and northwestern China (An et al., 2000; Li et al., 2004; Qin et al., 2005; Chen et al., 2006; Wang et al., 2005, 2007; Sun et al., 2010) yet their reconstructed approach for vegetation and climate change remain controversial. The Mongolian plateau has relatively few extended records of palaeovegetation and palaeo-climatic data. Earlier studies (Fowell et al., 2003; Prokopenko et al., 2007; Rudaya et al., 2008; Schlütz et al., 2008; Wang et al., 2004, 2009) represent short time interval and restricted mainly to Holocene climatic records from lake sediments. These Holocene records were mostly carried out in northwestern and central Mongolia. Additionally, these multi-proxy studies brought up contradictory ideas about vegetation, climate and the associated environmental history. The Gobi desert (southern Mongolia) is of interest for palaeo-vegetation and palaeo-climate studies because it is situated in the triangle of SE Asian monsoon, Indian monsoon and the westerlies. It is a region of strong climatic change (Herzschuh, 2006) and fragile ecosystems. It is, therefore, an archive being very sensitive to any vegetation and climate change and the lake sediments of the region will provide a record of the palaeo-vegetation history and palaeo-climate development.

In general, the major goal of this thesis research is to investigate late Quaternary vegetation history and climate variability of southern Mongolia using the sediments of lakes Bayan Tohomiin Nuur, Orog Nuur and Olgoy Nuur. The main purpose of the research study is highlighted with the help of the following main research headings.

A. The first scientific objective of our study is to investigate late Quaternary vegetation, climate and landscape history in arid Central Asia with the help of a multidisciplinary research of lake archive Bayan Tohomiin Nuur, Gobi desert, southern Mongolia.

The detail description of the subject above is narrated in chapter 2 and 3 as manuscript 1 and manuscript 2. The geochemical and granulometric analyses of a sediment core from Bayan Tohomiin Nuur have been carried out by Dr. Thomas Felauer; Department of Geography, RWTH Aachen University, Aachen. Waheed Murad; Department of Palynology and Climate Dynamics, Albrecht-von- 
Haller Institute for Plant Sciences, University of Göttingen., analyzed palynological record where as ostracod analyses was conducted by Prof. Steffen Mischke., Freie Universität, Institute of Geological Sciences, Berlin. The multiproxy results contribute to investigate the complicated pattern of climate history of Central Asia based on vegetation history under the shifting control of westerlies and the monsoon system. The research task helps to improve the understanding of palaeo-climate development in southern Mongolia during the last ca.15 ka cal BP and reflects different climatic and associated environmental stages. Our high resolution multidisciplinary record from a climatically sensitive shallow lake seems to highlight a detailed history of vegetation and landscape dynamics in high continental Asia from about 15.3 to $3.8 \mathrm{ka}$ cal BP. The reconstructed climatic phases can be correlated the Younger Dryas and the $8.2 \mathrm{ka}$ event respectively. A mid-Holocene climate moisture optimum is attributed to a strengthening of the westerlies. Nevetheless, a combined influence of westerlies and the summer monsoon caused a quite humid phase just before the Holocene optimum, while bordering areas in the North and South were dry. However, further investigations in southern Mongolia are needed to verify such a peculiar climate phenomena for high continental Mongolia to contribute to a secret activity of the complex spatial patterns of climate history in Central Asia (Herzschuh, 2006).

B. The second main objective is to reconstruct late Quaternary vegetation, climate and landscape development in arid Central Asia: A multidisciplinary research of lake archives Orog Nuur, Gobi desert, southern Mongolia.

Detail description of palynological record is given in chapter 4 as manuscript 3 whereas the manuscript regarding the multiproxy study of geochemical, palynological and ostracod analyses is in the process of preparation. The research site has not been investigated so far for palaeo-vegetation studies. Our high resolution geochemical, granulometric, palynological and ostracod analyses of a $1333 \mathrm{~cm}$ long sediment core from Orog Nuur represents the first detailed history of vegetation and climate change during the last ca. $50 \mathrm{ka}$ cal BP. The multidisciplinary research study will be providing a base line for further palaeo-vegetation and palaeo-climate research from a climatically sensitive region of continental Central Asia.

More specific objectives of the whole project are:

i) To carry out the interdisciplinary pollen, non-pollen palynomorphs, geochemical and ostracod studies from Bayan Tohomiin Nuur (BTN) between 15.3 -3.8 ka cal BP (chapters 2 and 3).

ii) To present the first high resolution palynological, geochemical and ostracod record from Orog Nuur (ONW-II) during the last ca. $50 \mathrm{ka} \mathrm{cal} \mathrm{BP} \mathrm{(chapter} 4$ for palynological analyses).

iii) To present the pollen record from Olgoy Nuur (OLG), central Mongolia (chapter 5).

iv) The multidisciplinary study is also used to test different qualitative approaches suggested for the vegetation and climate reconstruction in the arid Central Asia and to apply the reconstruction methods to the detailed and adequately dated pollen record from Bayan Tohomiin Nuur and Orog Nuur. 
v) To investigate past pollen and fungal diversity of southern Mongolia.

vi) To reconstruct climate, vegetation and land scape history based on pollen, fungal, geochemical and ostracod records.

vii) To prepare a master key for pollen grain identified from Bayan Tohomiin Nuur, Orog Nuur and Olgoy Nuur, southern Mongolia (chapter 6).

\subsection{General features}

The general features about location, soil, water resources, vegetation and climate of the study region with a general overview of the core sites are described as under.

\subsubsection{Location}

Mongolia is located between $87^{\circ} 41^{\prime \prime}$ and $119^{\circ} 56^{\prime \prime}$ East longitude and $41^{\circ} 35^{\prime \prime}$ and $52^{\circ} 09^{\prime \prime}$ North latitude in the central region of North-East Asia. It stretches $1259 \mathrm{~km}$ from North to South and 2392 $\mathrm{km}$ from East to West. Mongolia is a vast country with about $1,560,000 \mathrm{~km}^{2}$ area and sparsely populated central Asian nation of about 2.7 million people (Rudaya et al., 2008). In general, Mongolia mountains lie at elevations >1500 m whereas Mongolian plains having elevations between 800 to 1500 $\mathrm{m}$. Mongolia has numerous mountain ranges throughout the country including the Great Sayan, Buteel, and Hentei Mountains in the north., Great Hingan highlands in the east., Mongolian Altai and Gobi Altai ranges in the southeast and south and Han-hohii and Hangai Mountains in the west. Mountain peaks $>4000 \mathrm{~m}$ are concentrated in the Mongolian Altai (Mt. Huiten-Uul at $4374 \mathrm{~m}$ ) and Hangai Mountains (Mt. Otgon-Tenger at $4031 \mathrm{~m}$ ). The Gobi desert traverses the country along its southern border with China (Gunin et al., 1999; Jigjidsuren et al., 2003; Johnson et al., 2006; Ariunsuren et al., 2009).

\subsubsection{Soil}

The principal soil type is dry-steppe chestnut soil that covers some $40 \%$ of Mongolia. Other major soil types are brown desert-steppe and grey brown desert soils. Arable soils are generally dark chestnut and chestnut soils which are typically light, fine silty, around 20-30 cm deep with an organic matter content of 3-4\% and pH of 6-7 (Batjargal et al., 1997).

\subsubsection{Water resources}

Mongolia is situated between the basins of the Arctic and Pacific Ocean and the closed depressions of Central Asia (Gunin et al., 1999). The water resources such as lakes, streams and rivers are very common in the northern part of the country. Rivers originating from the northern mountain ranges of Altai, Hangai, Hentei, and Hovsgul flow into the Pacific Ocean. There are about 3811 streams and rivers flowing in Mongolia, covering more than 67,000 km area in length across Mongolia. The Selenge is the largest river with a total length of $600 \mathrm{~km}$. The Haraa and Eroo rivers converge with the Tuul river which originates on the southern slopes of the Hentei Mountains. The longest river draining into the Pacific Ocean is the Herlen river of which $1090 \mathrm{~km}$ flows through 
Mongolia. The deepest rivers draining into the Pacific Ocean are the Onon and Ulz rivers. Tes, Hovd, Zavhan, Baidrag, Tuin, Ongi and Bulgan rivers are without any access to the sea (Johnson et al., 2006).

Mongolia has more than 3000 lakes and ponds of which $80 \%$ are saline. The largest lake is Huvsgul lake which is $134 \mathrm{~km}$ long and $35 \mathrm{~km}$ wide. Almost 65\% of Mongolia has no open water sources, so livestock production in these areas critically depends on wells for watering livestock. About $35 \%$ of exploitable underground water sources are found in the Dornod plain, $25 \%$ in the Hangai-Hentei Mountains, 32\% in the Gobi desert, and $8 \%$ in the Altai Mountains. This means that $70 \%$ of underground water resources in Mongolia occur in the Gobi desert and steppe zones. During the past several decades, water use for irrigation, mining and other human activities has increased. Deforestation and climate change have purportedly resulted in substantial reductions in river flows, flow regimes and water levels or in some cases complete drying of lakes and the lowering of groundwater tables (Batjargal et al., 1997; Maygmarjav and Davaa, 1999; Johnson et al., 2006).

\subsubsection{Climate}

The climate of Mongolia is highly continental. It is characterized by very long and cold winters with low precipitation, hot summers and high temperature fluctuations. Snow may fall in the North mountainous regions. It contributes less than $20 \%$ to total annual precipitation owing to long periods of clear skies in winter due to the high anticyclone. Soils are completely frozen due to low cover of snow. The annual average air temperature for Mongolia is $0.7{ }^{\circ} \mathrm{C}$. It is $8.5^{\circ} \mathrm{C}$ in the warmest regions of the Gobi and south Altai deserts and $-7.8^{\circ} \mathrm{C}$ in the coldest region of the Darkhad depression. The lowest monthly average temperatures of $-15{ }^{\circ} \mathrm{C}$ to $-35{ }^{\circ} \mathrm{C}$ are recorded in January. It is -30 to $-34{ }^{\circ} \mathrm{C}$ in the valleys of the Altai, Khangai, Khuvsgul and Khentii mountains., -25 to $-30{ }^{\circ} \mathrm{C}$ in the high mountainous area., -20 to $-25{ }^{\circ} \mathrm{C}$ in the steppe and -15 to $-20^{\circ} \mathrm{C}$ in the Gobi desert. July is the warmest month. The average air temperature in July is $12{ }^{\circ} \mathrm{C}$ in the Altai, Khangai, Khuvsgul and Khentii Mountainous. 15$20{ }^{\circ} \mathrm{C}$ in the valleys of Mountains and $20-25{ }^{\circ} \mathrm{C}$ in southern part of the eastern steppe and the Gobi desert (Nandintsetseg et al., 2007).

The mean annual precipitation decreases steadily from north-west to south-east which is a key factor in the distribution of vegetation formations. The highest mean annual precipitation values of $300-400 \mathrm{~mm}$ (occasionally exceeding $600 \mathrm{~mm}$ ) may occur in the Khangai, Khentein and Khuvsgul mountainous region, $150-250 \mathrm{~mm}$ in the steppe and 100-150 $\mathrm{mm}$ in the steppe-desert. The Gobi desert has the lowest values of 50-100 mm and has periods without precipitation lasting several years. About $85 \%$ of total precipitation falls in summer. Although annual precipitation is low, its intensity is high. For example, an intense rainstorm of 40-65 mm may fall in a single hour (Batjargal et al., 1997; Batima et al., 2005; Ma et al., 2008). 


\subsubsection{Vegetation}

Biogeographically, Mongolia is a transitional zone from Siberian taiga to dry steppe, steppe-desert and desert in Central Asia. The major portion of its territory lies in the steppe and forest-steppe zones (Ma et al., 2008).

The Daurian steppes and the Altai-Sayan Mountains are considered the world's most biologically outstanding eco regions which lie partly within Mongolia and the Mongolian steppe represents one of the largest contiguous unaltered grasslands in the world. The general zonation of the vegetation of Mongolia, based on floristic composition and physiognomy, is given by Walter (1974) in German language. Johnson et al. (2006) recognized six major vegetation zones of Mongolia on the basis of difference in altitude, temperature, rainfall distribution and soils. These vegetation zones and the percentages of land area occupied by each are: alpine tundra (3\%), mountain taiga (4.1\%), mountain steppe and forest steppe (25.1\%), grass steppe (26.1\%), desert steppe (27.2\%) and desert (14.5\%). About $10 \%$ of the land scape of Mongolia is covered by various types of forests. Larix (73.6\%), Cedrus (13\%), Pinus (8\%), Betula (5\%) and other species (Abies, Populus) dominating the northern part of the country. The Haloxylon ammodendron forests spread in the arid and semi-arid regions, accounting for $28 \%$ of the forest cover (Batjargal et al., 1997). A detailed knowledge of current vegetation in Mongolia is carried out by Hilbig (1995). He classified the vegetation of Mongolia along a south-north transect in correlation with precipitation and reported five vegetation zones of desert, desert-steppe, steppe, forest-steppe and mountain taiga vegetation as given below

\section{Desert vegetation}

Desert vegetation is found in East Gobi where a mean annual temperature is usually about $4-6{ }^{\circ} \mathrm{C}$. Annual precipitation is usually less than $100 \mathrm{~mm}$, almost exclusively in summer. Winters are cold and

sunny. Common vegetation includes low shrubs and semi-shrubs, most of them belonging to the families Chenopodiaceae (Anabasis, Haloxylon, Kalidium, Kochia, Iljinia, Salsola, Sympegma, Nanophyton), Asteraceae (Ajania, Artemisia, Asterothamnus, Brachanthemum), Polygonaceae (Atraphaxis, Calligonum), Zygophyllaceae (Nitraria, Zygophyllum), Tamarucaceae (Reaumuria, Tamarix), Fabaceae (Caragana, Oxytropis), Rosaceae (Potaninia) and Convolvulaceae (Convolvulus). Anabasis and Haloxylon have a high degree of succulence (Fig. 1.1A and B).

\section{Desert-steppe vegetation}

Desert-steppe community is widespread in the northern parts of the East Gobi where the mean annual temperature is $3-4{ }^{\circ} \mathrm{C}$ and the mean annual precipitation is $100-200 \mathrm{~mm}$. The vegetation is dominated by Artemisia species such as A. xerophytica, A. caespition, A. frigida mixed with Stipa species like Stipa krylovii, S. gobica, representing Artemisia-Stipa desert-steppe community. The other common species include Agropyrum sibiricum, Allium mongolium, Caragana pyhmaea, $C$. leucophloea, Convolvulus ammannii, Heteropappuss hispidus, Scorzonera divaricata, Anabasis brevifolia, Salsola passerine, Kochia prostrata, Eurotia cerataide Reaumuria soongorica, Oxytropis 
aciphylla, Peganum nigellastrum, Potaninia mongolica, and Tanacetum sibiricum, T. achillaeoides, and T. trifidum, Zygophyllum xanthoxylon.
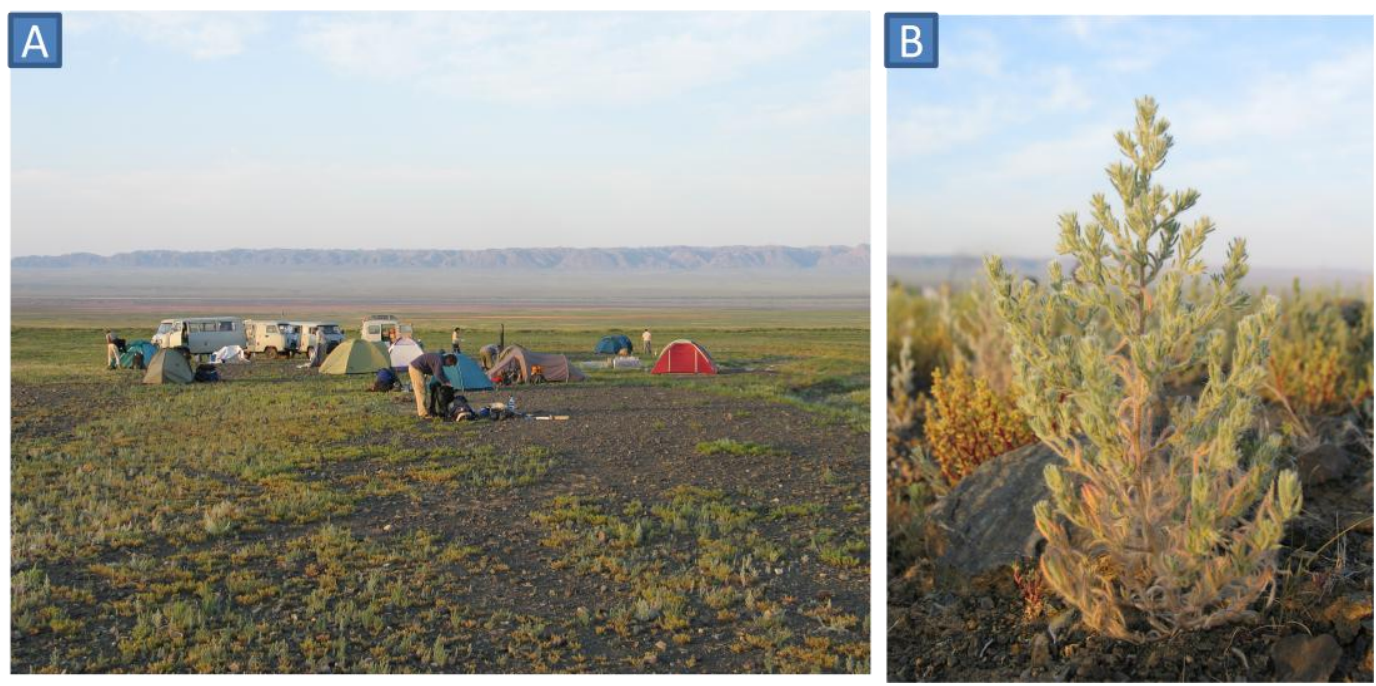

Fig. 1.1A: Picture showing Chenopodiaceae desert in the surrounding of BTN (source Frank Schlütz)

Fig. 1.1B: A common plant member of Chenopodiaceae in the study area (source Frank Schlütz)

\section{Steppe vegetation}

Steppe vegetation includes Artemisia-Stipa grass steppe and Stipa-Leymus steppe communities. They occupy the central and eastern Mongolia, at elevations between 950 and $1400 \mathrm{~m}$. The trees do not survive anymore and grasses dominate the vegetation. The mean annual temperature in this region ranges from $3-2{ }^{\circ} \mathrm{C}$ and the annual precipitation in varies from 200-300 mm. Dominant species are Stipa capillata, Cleistogenes squarrosa and Artemisia frigida. Some other common species are Agropyrum cristatum, Elymus chinensis, Carex durinscula, Artemisia adamsii, A. scoparia, A. plusfria, A. peatinata, Achnatherum splendens, Cymbaria dahurica, Leymus chinensis, Goniolimion speciosum, Kochina prostrate, Saussurea salicifolia and Peganum harmile, Caragana pygmaes.

\section{Forest-steppe vegetation}

The forest-steppe vegetation is distributed in the North and North-east of the Hangai and to the north-west, west and south of the Hentiy. The mean annual precipitation is usually $300-400 \mathrm{~mm}$. The mean annual temperature is 0 to $-2{ }^{\circ} \mathrm{C}$. This vegetation type separates the mountain taiga zone in the north from the steppe and desert-steppe zones in the south. The forest-steppe vegetation is consisting of a mosaic of patches of forest and grassland. Due to differences in topography there is a differentiation of the vegetation in forest on the north-facing slopes and higher parts and steppes on the south-slopes and in valleys (Hilbig, 1995). The plants such as Stipa krylovii, Poa attenuata and Artemisia species are the main species growing in forest steppe vegetation. With increase the forests steppe are built by Larix sibirica partly mixed with Betula and Pinus sylvestris. Other common herbaceous species include Aster alpinus, Saussurea salicifalre, Thalictrum foetidum, Astragalus 
brevifolius, Oxytropis pumila, Pulsatilla, Thymus serpyllum, Allium bidentatum, Arenaria capillaris, Bupleurum bicaule, Hedysarum pumilum, Iris potaninii, Pedicularis flava, Ptilotrichum canescens, Potentilla sericea, P. acaulis, Stellaria petraea, Stellaria chamaejasme and Sibbaldianthe adpressa. Overgrazed spots of higher mountain steppe are dominated by Carex duriuscula with Artemisia frigida.

\section{Mountain taiga vegetation}

The mountain taiga vegetation is occupying the Hovsgol Nuur area. The mean annual precipitation is more than $400 \mathrm{~mm}$. The characteristic plant species of mountain taiga include Larix sibirica (72\% of total forest area), Pinus sibirica (12\%), Pinus sylvestris (7\%) and Picea obovata (0.25\%) with shrub layer of Rosa acicularis and Betula rotundifolia. Spiraea alpina, Lonicera altaica, Juniperus sibirica and Rhododendron species prefer high altitude.

\subsection{Sediment coring sites}

The research was carried out on three sediment cores taken at Bayan Tohomiin Nuur (BTN), Orog Nuur (ONW) and Olgoy Nuur (OLG) during two field excursions scheduled on August, 2007 and August, 2008. All these three core sites are situated at the transition zone between the Gobi desert and steppe of arid southern Mongolia, representing archives very sensitive to past vegetation, climatic changes and landscape development. The first high resolution multi-proxy analysis of the $700 \mathrm{~cm}$ long core taken from Bayan Tohomiin Nuur and $1335 \mathrm{~cm}$ long core from Orog Nuur included the investigation of geochemical, granulometric, palynological and ostracod analyses. The multi-proxy data was used to reconstruct the geomorphologic, climatic and sedimentary processes at the catchment area of both lakes during the last $\sim 15 \mathrm{ka}$ and $\sim 50 \mathrm{ka}$ BP. respectively. The sediment samples, collected from different profiles of Olgoy Nuur, were also investigated for pollen analyses to reconstruct the vegetational and climatic change during late Pleistocene and Holocene. The detail of the pollen record sites is below.

The Bayan Tohomiin Nuur, a dry lake, is located in Gobi desert region. The Gobi desert includes the semi arid and arid southern portion of Mongolia. This region has elevations ranging between 700 and $1400 \mathrm{~m}$. Mean annual temperature of $0.0^{\circ} \mathrm{C}$ to $>2.5^{\circ} \mathrm{C}$ with the coldest temperature in January ($20^{\circ} \mathrm{C}$ ) and warmest temperature $\left(23^{\circ} \mathrm{C}\right)$ in July. Mean annual precipitation is about $100 \mathrm{~mm}$. Lack of snow as a water source is a major factor limiting livestock production in the Gobi desert region. Wind speed averages 2 to $8 \mathrm{~m} / \mathrm{sec}$. (Johnson et al., 2006).

Orog Nuur is located at $100^{\circ} 34^{\prime} \mathrm{E}$ longitude, $45^{\circ} 11^{\prime} \mathrm{N}$ latitude with about $1280 \mathrm{~m}$ elevation. It is situated in the valley of Gobi lakes, desert steppe sub region of Northwestern Mongolia (Yang et al., 2004) and is fed by the Tüin Gol from the Hangai Mountains, in addition to smaller drainages from the Ikh Bogd range of the Gobi Altai (Komatsu et al., 2001). The desert steppe region includes a broad treeless region in central and eastern Mongolia which is characterized by low knolls, hills and high plains. This region has elevations ranging from $900-2000 \mathrm{~m}$. temperature drops to $-20{ }^{\circ} \mathrm{C}$ in January 
and may rise up to $22{ }^{\circ} \mathrm{C}$ in July. Mean annual precipitation of $150-250 \mathrm{~mm}$. Snow depth ranges between 5-10 mm (Johnson et al., 2006).

The Olgoy Nuur lies at the southern side of the Hangai Mountains in the valley of Gobi lakes. The climate of the valley is extremely continental. The summers are very hot and arid where as winters are cold and dry. The mean annual temperature is $2{ }^{0} \mathrm{C}$ to $-6{ }^{0} \mathrm{C}$ but can vary from $-16{ }^{0} \mathrm{C}$ in January to 20 ${ }^{0} \mathrm{C}$ in July. The mean annual precipitation is about $250 \mathrm{~mm}$ (Tuvdendorzh and Myagmarzhav, 1985; Finch, 1996).

\subsection{Materials and methods}

\subsubsection{Field work}

Consecutive two field trips were arranged by Frank Schlütz., Department of Palynology and Climate Dynamics, University of Göttingen, Germany and Thomas Felauer., Department of Geography, RWTH Aachen University, Germany, in August, 2007 and August, 2008. During these two field excursions lake sediment cores were taken from Bayan Tohomiin Nuur (KEO-I), Orog Nuur (ONW-II) and Olgoy Nuur (OLG) in order to reconstruct vegetation, environmental and climatic history in the basins of the Gobi desert and Gobi Altai (Fig.1.2A and B). The OLG pollen analysis was carried out as a supplementary study (chapter 5.1).
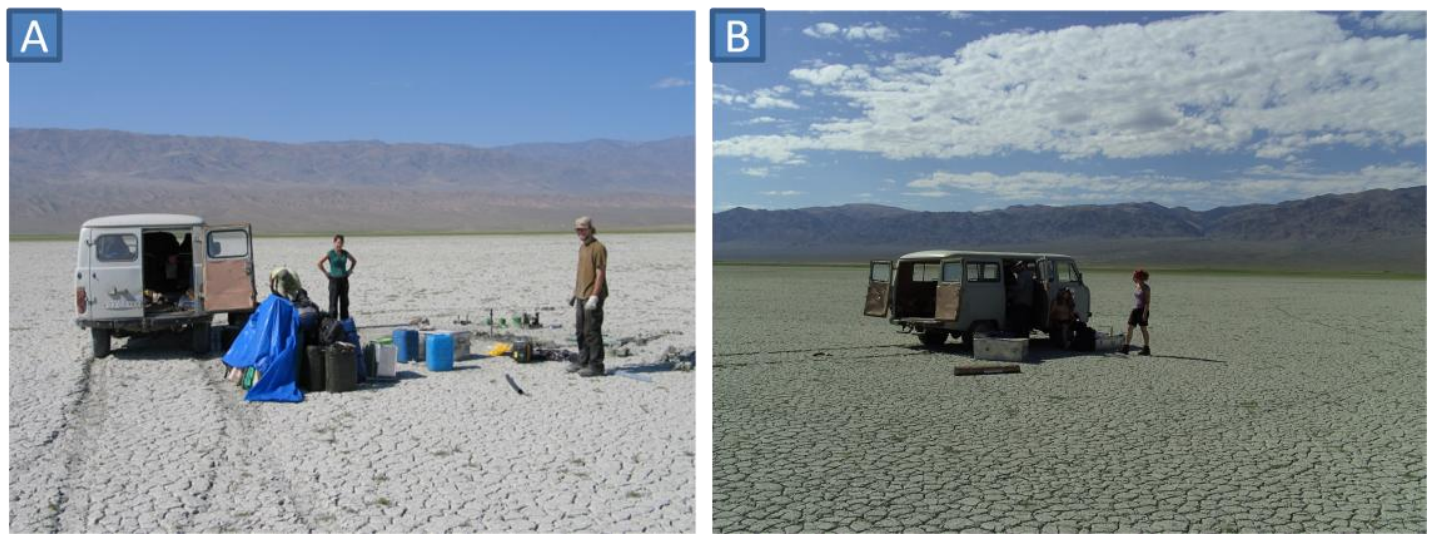

Fig. 1.2A: Collection of sediment samples from BTN (source Frank Schlütz)

Fig. 1.2B: Collection of sediment samples from ONW (source Thomas Felauer)

A $7 \mathrm{~m}$ core (KEO-I) was taken from lake Bayan Tohomiin Nuur with a percussion corer (Nordmeyer $\mathrm{GmbH}$ and Co. KG, Germany) at the northern margin of the basin $\left(43^{\circ} 34^{`} \mathrm{~N}, 103^{\circ} 11^{\prime} \mathrm{E}, 1420 \mathrm{~m}\right.$ elevation. Similarly a $1335 \mathrm{~cm}$ long sediment core (ONW-II) was also drilled at Orog Nuur, $\left(100^{\circ} 34^{\prime}\right.$ E longitude, $45^{0} 11^{\prime} \mathrm{N}$ latitude, 1280 elevation), south Mongolia. In case of KEO-I the unconsolidated upper $200 \mathrm{~cm}$ (ten samples, $10 \mathrm{~cm}$ thickness each) were taken at the coring site for geochemical analysis. This upper part was not suitable for pollen analysis. The samples of KEO-I and OLG were preserved and transported in plastic tubes to Georg-August University, Göttingen where they were opened with an oscillating saw, cleaned and visually described. The extraction of samples of KEO-I 
(700-200 cm) was done for palynological analyses. Steffen Mischke carried out the ostracod analysis at Department of Earth Sciences, Institute of Geographical Sciences, Freie Universität, Berlin where as $\mathrm{XRF}$, grain size, $\mathrm{CaCO} 3, \mathrm{CNS}$ and total organic carbon (TOC) were analyzed by Thomas Felauer at RWTH Aachen University, Aachen. The samples of OLG were analyzed for only pollen studies. The core fragments of ONW-II $(1333 \mathrm{~cm})$ were also preserved and transported in plastic tubes to Alfred Wegener Institute for polar and marine research (AWI), Bremerhaven where they were opened with an oscillating saw, cleaned and visually described. The extraction of samples for XRF, grain size, CaCO3, CNS and total organic carbon (TOC) were analyzed by Thomas Felauer. The palynological study was conducted at the Georg-August University Göttingen where as the ostracod analysis was done at Department of Earth Sciences, Institute of Geographical Sciences, Freie Universität, Berlin by Steffen Mischke.

\subsubsection{Laboratory work}

A total of 211 sampling units were investigated from the sediment core of BTN (KEO-I, 56 samples), Orog Nuur (ONW-II, 123 samples) and Olgoy Nuur (OLG, 32 samples). Sediment samples of $0.5-2 \mathrm{~cm}^{3}$ were collected at every $5-10 \mathrm{~cm}$ interval depending upon the pollen concentration. All the samples were treated for pollen analysis with standard methods using $\mathrm{KOH}, \mathrm{HCl}, \mathrm{HF}$ and acetolysis (Erdtman, 1960; Moore et al., 1999). Lycopodium spores were added to each sample in order to calculate concentration (pollen grains $/ \mathrm{cm}^{3}$ ), influx of pollen (pollen grains $/ \mathrm{cm}^{2} / \mathrm{yr}$ ) and charcoal. The suspensions were sieved in an ultrasonic bath through a $1.5 \mathrm{um}$ mesh and stored in glycerin.

\subsubsection{Radiocarbon dating}

In total, 17 bulk samples were taken from core KEO-I and ONW-II for Accelerator Mass Spectrometer (AMS) radiocarbon dating (Table 1.1). The bulk samples for AMS radiocarbon dates were processed at the University of Erlangen/Nürnberg, Germany and Poznań Radiocarbon laboratory, Poland for the determination of cores chronology. Radiocarbon ages have been calibrated with the online version of the program CalPal: http://www.calpal-online.de/CalPal2007-HULU (Weninger and Jöris, 2008) in order to construct age-depth models. The age depth models for the lake archives of BTN and Orog Nuur (ONW) were reconstructed using polynomial function (chapter 2 and 3) and linear interpolation (chapter 4).

\subsubsection{Identification of pollen and spores}

In arid environments the number of identified pollen taxa is limited (Herzschuh et al., 2004); therefore, a maximum number of about 400 pollen grains were counted in each sample. Pollen concentration in a few samples of both cores was very low. A total of about 140 different palynological taxa have been distinguished in the fossil pollen spectra of all the three sediment cores (Apendix I) of which almost 50 were pollen types, about 40 were identified as fungal spores. Other taxa include Pediastrum, Botryococcus, Volvocaceae, Chironomids, monolete and trilete spores, Foraminifera, Filinia longesta and eggs of Trichuris. About 40 fungal spores and algal types remained unknown. 
Both pollen and spore taxa have been identified with the help of reference collection of Frank Schlütz and available literature (Vanky, 1994; Moore et al., 1999; van Geel et al., 2003; Beug, 2004).

\begin{tabular}{|l|l|l|l|l|l|l|}
\hline $\begin{array}{l}\text { Core } \\
\text { name }\end{array}$ & $\begin{array}{l}\text { Depth } \\
{[\mathrm{cm}]}\end{array}$ & Lab. No & $\begin{array}{l}14 \mathrm{C} \text { age and } \\
\text { error [yr. BP] }\end{array}$ & $\delta^{13} \mathrm{C}[\%$ ] & $\begin{array}{l}\text { Calibrated age } \\
\text { and SD [cal. } \\
\text { yr. BP] }\end{array}$ & material \\
\hline BTN & 247 & Poz-37868 & $5495 \pm 35$ & -21.3 & $6299 \pm 24$ & bulk sample \\
\hline BTN & 253 & Erl-13181 & $5880 \pm 46$ & -20.5 & $6709 \pm 45$ & bulk sample \\
\hline BTN & 353 & Erl-12109 & $8697 \pm 56$ & -22.7 & $9674 \pm 85$ & bulk sample \\
\hline BTN & 367 & Poz-37949 & $9270 \pm 50$ & -25.1 & $10441 \pm 88$ & bulk sample \\
\hline BTN & 367 & Poz-37869 & $9320 \pm 60$ & -24.6 & $10523 \pm 90$ & bulk sample \\
\hline BTN & 526 & Erl-13182 & $6037 \pm 47$ & -21.6 & $6884 \pm 64$ & bulk sample \\
\hline BTN & 536 & Poz-37870 & $6920 \pm 40$ & -26.8 & $7222 \pm 36$ & bulk sample \\
\hline BTN & 674 & Erl-12110 & $10661 \pm 56$ & -23.3 & $12661 \pm 65$ & bulk sample \\
\hline BTN & 665 & Poz-37871 & $11170 \pm 70$ & -27.4 & $13073 \pm 125$ & bulk sample \\
\hline ONW & 94 & ERL-15622 & $12581 \pm 103$ & -25.4 & $12973 \pm 323$ & bulk sample \\
\hline ONW & 199 & ERL-15623 & $13242 \pm 85$ & -24.2 & $14223 \pm 413$ & bulk sample \\
\hline ONW & 271 & ERL-15624 & $17733 \pm 149$ & -25.4 & $19215 \pm 354$ & bulk sample \\
\hline ONW & 392 & ERL-15625 & $17713 \pm 180$ & -24.5 & $19192 \pm 379$ & bulk sample \\
\hline ONW & 571 & ERL-15626 & $19738 \pm 179$ & -23.8 & $21670 \pm 348$ & bulk sample \\
\hline ONW & 778 & ERL-15627 & $21501 \pm 217$ & -24.2 & $23714 \pm 444$ & bulk sample \\
\hline ONW & 1192 & ERL-15628 & $46103 \pm 2281$ & -25.4 & $48072 \pm 3111$ & bulk sample \\
\hline ONW & 1272 & ERL-15629 & $40429 \pm 1340$ & -25.92 & $42241 \pm 1147$ & bulk sample \\
\hline
\end{tabular}

Tab. 1.1: Results of the AMS ${ }^{14} \mathrm{C}$-datings of BTN and ONW and their calendric age-conversion (calibration) with $1 \sigma$ standard deviation (SD) using "CalPal-online" (Weninger and Jöris 2008)

\subsubsection{Data presentation}

The calculation of pollen and spore percentages is based on the pollen sum of about 400 pollen grains per sample containing all arboreal pollen (AP) and non-arboreal pollen (NAP) except Cyperaceae and aquatic plants. The palynological data are presented in the pollen diagram as percentages of the pollen sum. The software $\mathrm{C} 2$ version 1.5.1 was used to plot the pollen and spore data as stratigraphic diagram (Juggins, 2007). In diagram, all the palynological taxa are arranged according to their ecology and chronological order.

\subsection{Pollen-climate indices}

\subsubsection{Introduction}

The traditional interpretation of the individual pollen percentages and concentrations in sediment samples of arid and semi arid regions of Central Asia seem difficult to reconstruct past vegetation and climate history effectively because of poor pollen identification and the lack of good indicator taxa. The ratios of various pollen types have been applied as environmental indicators in arid regions in order to infer vegetation and climate change. The Artemisia/Chenopodiaceae $(\mathrm{A} / \mathrm{C})$ ratio has been introduced for the first time as a moisture indicator in the Middle East (El-Moslimany, 1990). This approach has also been used in Central Asia (Demske and Mischke, 2003; Herzschuh et al., 2004). 
Herzschuh et al. (2006) introduced that the Artemisia/Cyperaceae (A/Cy) ratio can serve as a semiquantitative measure for summer temperature changes on the central and eastern Tibetan Plateau. Herzschuh et al. (2004) also suggested Ephedra fragilis-type/ Ephedra distachyia-type (Ef/Ed) ratio and interpreted dry conditions based on high values of Ephedra fragilis-type in Ef/Ed ratio. Yu et al. (1998) and Cour et al. (1999) reported that Chinese desert areas yield A/C values below 0.5. Fowell et al. (2003) calculated a semi-quantitative 'aridity pollen index' expressed as a ratio of Artemisia + Chenopodiaceae by dividing the percentage of Poaceae to distinguish dry steppe from moist meadow steppe and forest-steppe vegetation in North-central Mongolia. The higher values of the index (>5) interpret arid conditions that favor desert-steppe where as low values $(<5)$ are indicative of high moisture availability to support meadow steppe and forest-steppe vegetation. Similarly, several quantitative methods such as the response surface analysis and transfer function have been applied to modern pollen and vegetation for the reconstruction of climate variables. However, these methods cannot be effectively applied to the continental Mongolia due to the low availability of modern climatic data (Ma et al., 2008).

Poaceae pollen in extreme arid conditions are more abundant locally in the azonal vegetation communities, except in some areas that are disturbed by overgrazing. Owing to the possible distortion of Poaceae pollen abundance by human activities in these arid and semi-arid environments, the 'aridity pollen index' expressed as a ratio of desert-steppe (Artemisia + Chenopodiaceae) to steppe (Poaceae) taxa may not be an appropriate indicator to use for palaeoclimatic reconstruction (Herzschuh et al., 2004; Ma et al., 2008).

In our study, two new pollen-climate indices, a moisture index (M) and a temperature index (T), are introduced for Mongolia (Table 1.2). Both climate indices are calculated based on the ratios between groups of pollen taxa that represent different moisture or temperature conditions in the climate-sensitive study region.

The main pollen taxa were distinguished into six pollen groups based on their relationships to six major vegetation communities proposed by Ma et al., (2008). Group S1, containing Chenopodiaceae, Nitraria and Zygophyllaceae (Tribulus terristris), is a representative of xeromorphic desert. Group S2 includes Convolvulus, Anthemis-type (Matricaria-type), Ephedra and Liliaceae (Allium) which occurs commonly in desert-steppe. Group S3 (Artemisia) represents meso-xeromorphic steppe. Groups S4 represent the birch forest/shrub land (Betula, Rosaceae, Taraxacum-type (Liguliflorae). Cold-moist needle-leaved forest (Picea, Larix, Pinus Haploxylon-type, Pinus Diploxylon-type, Ranunculaceae and Caryophyllaceae) is represented by Group S5 where as Group S6 is including Cyperaceae, Polygonaceae, is indicative of moderate hydro period steppe vegetation types. A total of 19 pollen taxa are considered to derive $\mathrm{M}$ and $\mathrm{T}$ climate indices. Poaceae is excluded from all six groups because its abundance could be distorted by human disturbance as discussed above. 
The temperature index (T) and moisture index (M) is calculated as follows:

$$
\begin{aligned}
& \mathrm{T}=(\mathrm{PS} 1+\mathrm{PS} 2+\mathrm{PS} 3) /(\mathrm{PS} 4+\mathrm{PS} 5+\mathrm{PS} 6) \\
& \mathrm{M}=(\mathrm{PS} 5+\mathrm{PS} 6) /(\mathrm{PS} 1+\mathrm{PS} 2+\mathrm{PS} 3+\mathrm{PS} 4)
\end{aligned}
$$

\begin{tabular}{|c|c|c|}
\hline Group & Vegetation type & Main pollen taxa \\
\hline $\mathrm{S} 1$ & Xeromorphic desert & $\begin{array}{l}\text { Chenopodiaceae, Nitraria, Zygophyllaceae, } \\
\text { (Tribulus terristris) }\end{array}$ \\
\hline $\mathrm{S} 2$ & Desert steppe & $\begin{array}{l}\text { Anthemis-type (Matricaria-type), Liliaceae, Ephedra, } \\
\text { Convolvulus }\end{array}$ \\
\hline S3 & Meso-xeromorphic steppe & Artemisia \\
\hline $\mathrm{S} 4$ & Birch forest/shrubs & Betula, Rosaceae, Taraxacum-type (Liguliflorae) \\
\hline S5 & Cold-moist needled forest & $\begin{array}{l}\text { Picea, Larix, Ranunculaceae, Caryophyllaceae } \\
\text { Pinus Diploxylon-type, Pinus Haploxylon-type }\end{array}$ \\
\hline \multirow[t]{3}{*}{ S6 } & $\begin{array}{l}\text { Moderate hydro period } \\
\text { steppe }\end{array}$ & Cyperaceae, Polygonaceae \\
\hline & & Calculation \\
\hline & Pollen-climate indices & \\
\hline $\mathrm{T}$ & Temperature index & $\mathrm{T}=(\mathrm{PS} 1+\mathrm{PS} 2+\mathrm{PS} 3) /(\mathrm{PS} 4+\mathrm{PS} 5+\mathrm{PS} 6)$ \\
\hline M & Moisture index & $\mathrm{M}=(\mathrm{PS} 5+\mathrm{PS} 6) /(\mathrm{PS} 1+\mathrm{PS} 2+\mathrm{PS} 3+\mathrm{PS} 4)$ \\
\hline
\end{tabular}

Table 1.2: Selected pollen taxa in the pollen groups (S1-S6) used in the calculation of the pollen ratios which were ultimately used for the calculation of temperature index $(\mathrm{T})$ and moisture index $(\mathrm{M})$.

\subsubsection{Methodology}

Several semi quantitative methods have been tested to use the ratios of various pollen types as a tool for palaeo-environmental characteristics. Temperature $(T)$ and moisture $(M)$ indices were derived using the six pollen groups (S1-S6) for the calculation of the pollen ratios which represent different moisture or temperature conditions in the studied site. The pollen percentage of each pollen group (S1 S6) for each surface sample is calculated and plotted these values for all the samples along the curves for the moisture index as well as the temperature index to examine their spatial variation. We also plotted the $\mathrm{A} / \mathrm{C}, \mathrm{A} / \mathrm{A}+\mathrm{Ch}, \mathrm{A}+\mathrm{Ch} / \mathrm{Poa}, \mathrm{Poa} / \mathrm{A}+\mathrm{Ch}, \mathrm{A}+\mathrm{Ch} / \mathrm{Poa}+\mathrm{Th}+\mathrm{Cy}, \mathrm{Poa}+\mathrm{Th}+\mathrm{Cy} / \mathrm{A}+\mathrm{Ch}$ and Ephedra+Glomus pollen ratios along the transect, in order to test the validity of temperature and moisture indices curves with different ratios of various pollen types (Fig. 1.3 and Fig. 1.4 for BTN and Fig. 1.5 for ONW core). 


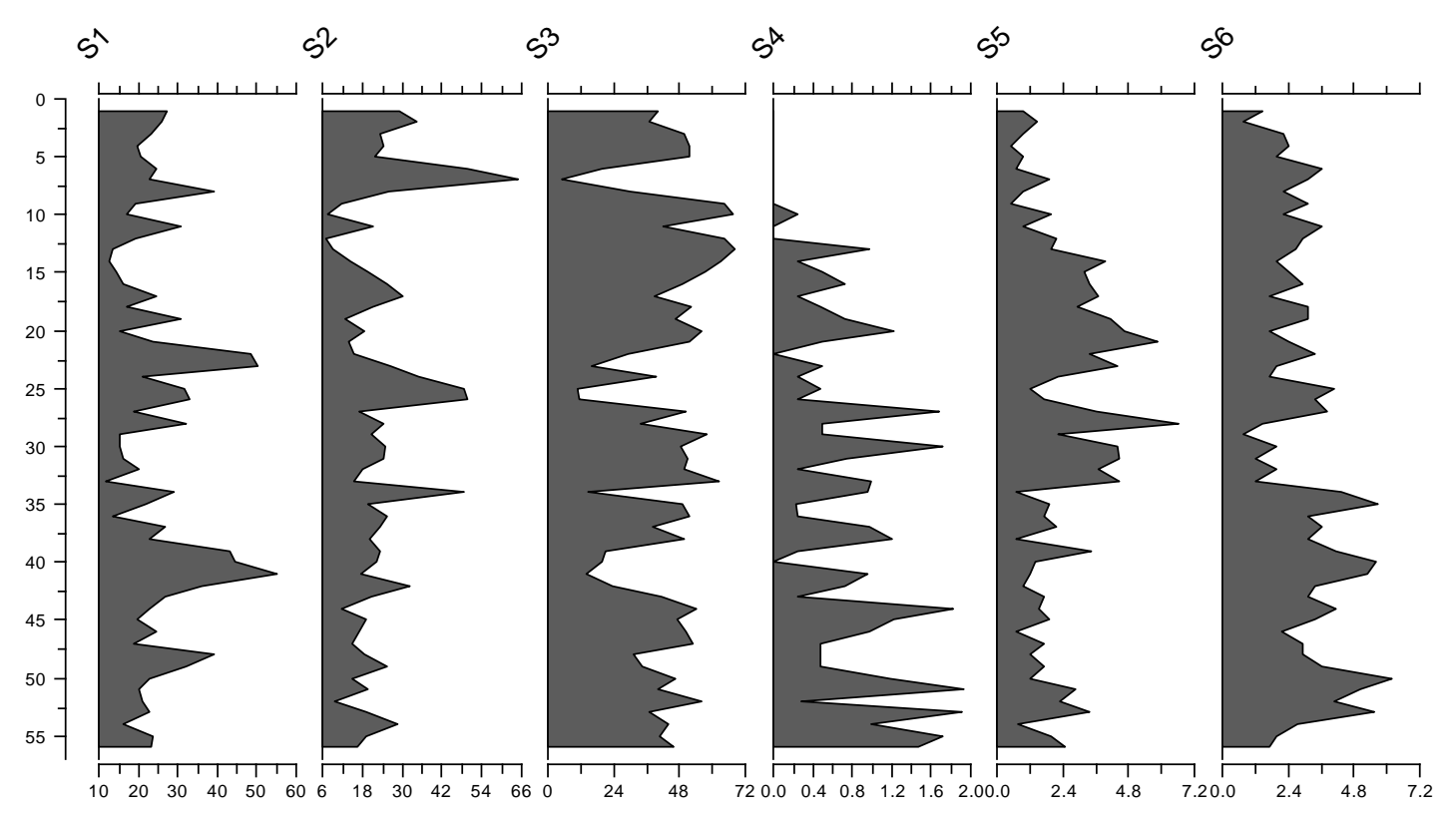

Fig.1.3: Grouped pollen percentages of the six pollen groups (S1-S6) from BTN core used in the calculation of pollen-climate indices

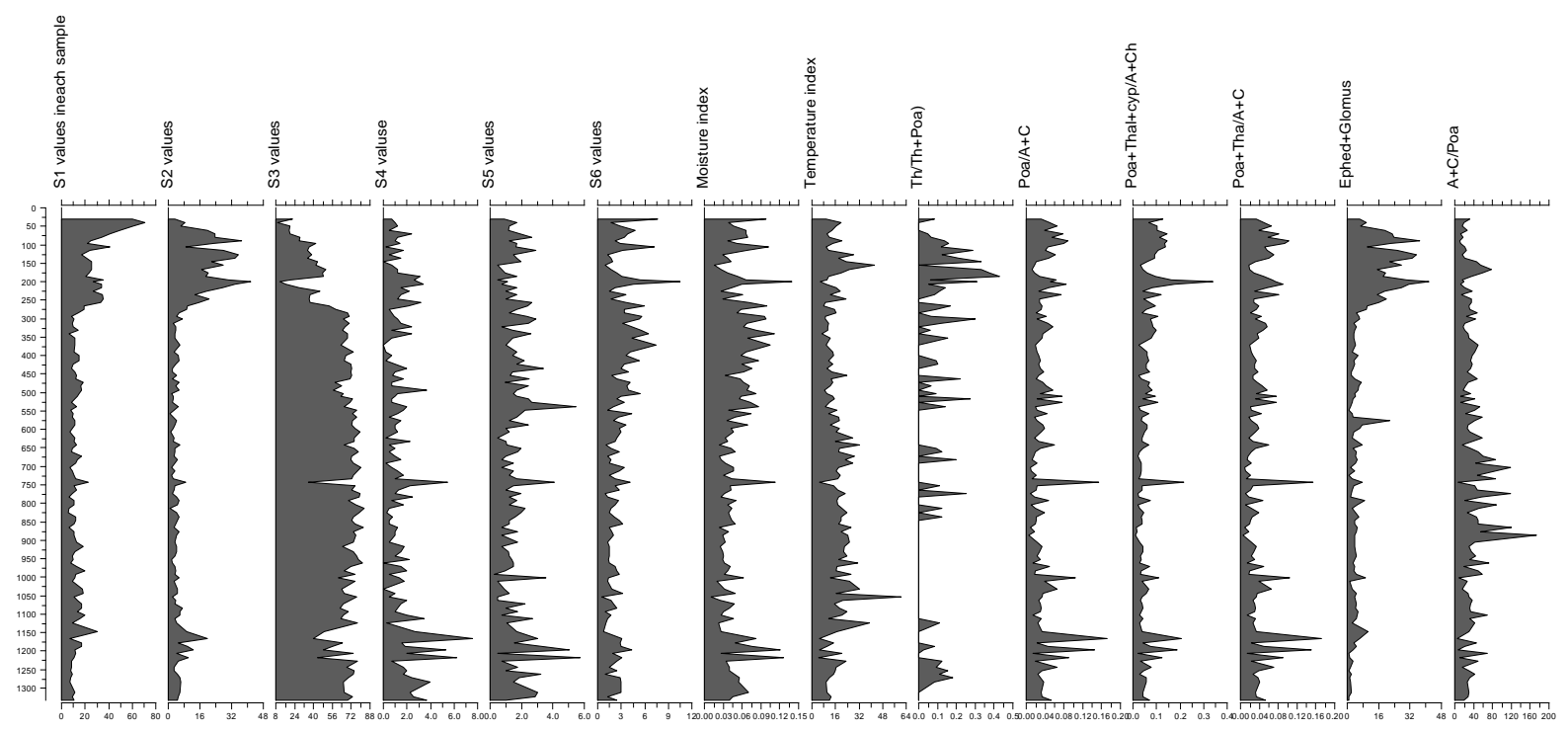

Fig.1.4: Grouped pollen percentages of the six pollen groups (S1-S6) from ONW sediment samples used in the calculation of pollen-climate indices 


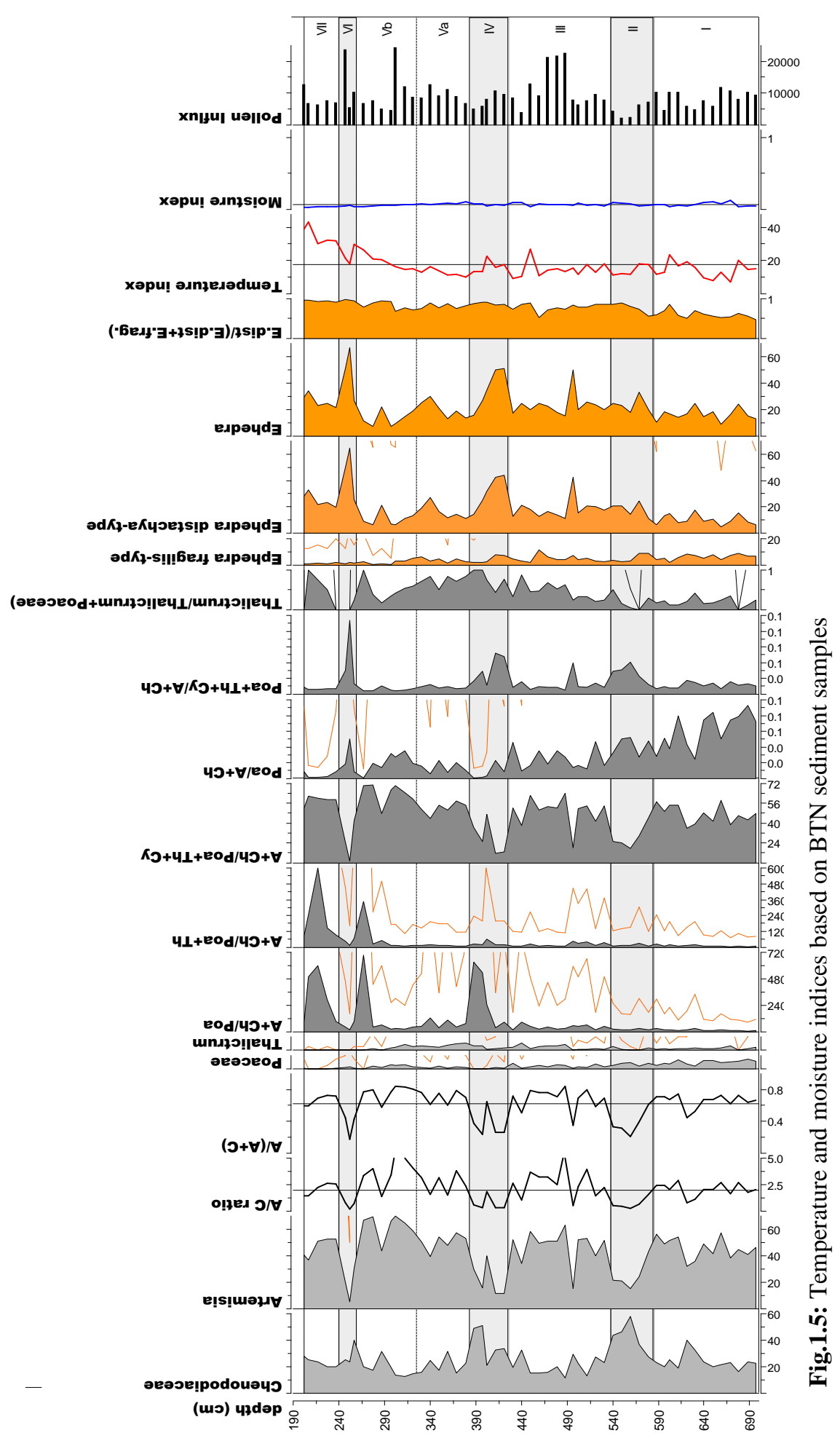




\subsubsection{General interpretation}

We did not graph "(Artemisia + Chenopodiaceae) / Poaceae" but the reciprocal Poaceae/ (Artemisia + Chenopodiaceae) curve because Poaceae pollen in extreme arid conditions are more abundant locally in the azonal vegetation communities, except in some areas that are disturbed by overgrazing. Owing to the possible distortion of Poaceae pollen abundance by human activities in these arid and semi-arid environments, the 'aridity pollen index' expressed as a ratio of desert-steppe (Artemisia + Chenopodiaceae) to steppe (Poaceae) taxa may not be an appropriate indicator to use for palaeoclimatic reconstruction (Herzschuh et al., 2004, Ma et al., 2008). Poaceae + Thalictrum + Cyperaceae represent forest steppe forb, alpine steppe, meadow steppe forb and moist/ wet conditions in contrast to Artemisia + Chenopodiaceae in the Poa+Th+Cy/A $+\mathrm{Ch}$ index. High Ephedra + Glomus values are showing very dry and cold climate causing severe erosion due to low vegetation cover Ephedra + Glomus curve does not fit to the temperature and the moisture indices because Ephedra is a typical desert species., however, low values of Ephedra pollen may not be a good vegetation indicator because it produces large amounts of pollen that are transported long distances. For example, Ephedra pollen has been documented in Midwestern North America, even though its parent plants are thousands of kilometers away in the deserts of the southwestern USA (Maher, 1964). Li et al. (2005) reported that in the eastern Alashan Plateau, eastern Qaidam Basin and part of Gansu Corridor, Ephedra pollen appears in most surface samples, even though no Ephedra plants are recorded in the surrounding communities. Therefore, Ephedra pollen in low abundance has limited climate information (Zhao et al., 2007).

The Poa+Th+Cy/A+Ch index curve is fitting best to the Ephedra + Glomus curve. The increasing trend is representing dry cold while increasing trend indicates moist warm conditions.

\subsection{References}

An, Z., Porter, S., Kutzbach, J., Wu, X., Wang, S., Liu, X., Li, X., Zhou, W., 2000. Asynchronous Holocene optimum of the East Asian monsoon. Quaternary Science Reviews 19, 743-762.

Ariunsuren, P., Damiran, D., Stevens, P., 2009. Results of assessment of the current status of degree of disturbance of the desert-steppe range lands of western Mongolia. In: Proc. Soils and Crops conference. Saskatoon, SK., Canada.

Batima, P., Dagvadorj, D., 1998. Climate change and its impacts in Mongolia. JEMR Publisher, Ulaanbaatar, Mongolia.

Batima, P., Natsagdorj, L., Gombluudev, P., Erdenetsetseg, B., 2005. Observed climate change in Mongolia. AIACC Working Paper No.12.

Batima, P., 2006. Climate change vulnerability and adaptation in the livestock sector of Mongolia: A final report submitted to assessments of impacts and adaptations to climate change (AIACC), Project No. AS 06. The International START Secretariat. 
Batjargal, Z., 1997. Desertification in Mongolia. Proceedings of an international workshop on range land desertification. RALA Report No. 200. Agricultural Research Institute.

Bedunah, D.J., McArthur, E.D., Fernandez, G., Maria, C., 2006. Rangelands of Central Asia: Proceedings of the conference on transformations, issues and future challenges. Salt lake city, UT. Proceeding RMRS-P-39. Fort collins, CO: U.S. Department of Agriculture, Forest Service, Rocky Mountain Research Station.

Beug, H.J., 2004. Leitfaden der Pollenbestimmung für Mitteleuropa und angrenzende Gebiete, Pfeil Verlag, München.

Chase, T.N., Pielke, R.A., Knaff, J., Kittel, T., Eastman, J., 2000. A comparison of regional trends in 1979-1997 depth-averaged troposphere temperatures. International Journal of Climatology 20, $503-518$.

Chen, F.H., Chen, B., Zhao, Y., Zhu, Y., Madsen, D.B., 2006. Holocene environmental change inferred from a high-resolution pollen record, lake Zhuyeze, arid China. The Holocene 16, $675-684$.

Cour, P., Zheng, Z., Duzer, D., Calleja, M., Yao, Z., 1999. Vegetational and climatic significance of modern pollen rain in Northwestern Tibet. Review of Palaeobotany and Palynology 104, 183204.

Demske, D., Mischke, S., 2003. Palynological investigation of a Holocene profile section from the Palaeo-Gaxun-Nur-Basin, Chinese Science Bulletin 48, 1418 - 1422.

Dulamsuren, C., Hauck, M., Leuschner, C., 2010. Recent drought stress leads to growth reductions in Larix sibirica in the western Khentey, Mongolia. Global Change Biology 16, 3024 - 3035.

El-Moslimany, A.P., 1990. Ecological significance of common non arboreal pollen: Examples from dry lands of the Middle East. Review of Palaeobotany and Palynology 64, 343-350.

Erdtman, G., 1960. The acetolysis method. Svensk Botanisk Tidskrift. 54, 561-564.

Finch, C., 1996. Mongolia's wild heritage. Mongolian Ministry for Nature and the Environment. Hong Kong: Avery Press.

Fowell, S., Hansen, B. Peck, J.A., Khosbayar, P., Ganbold, E., 2003. Mid to late Holocene climate evolution of the lake Telmen Basin, North Central Mongolia based on palynological data. Quaternary Research 59, 353-363.

Gunin, P.D., Vostokova, E.A.,Dorofeyuk, N.I., Tarasov, P.E., Black, C.C., 1999. Vegetation Dynamics of Mongolia. Geobotany 26, 233-238. Kluwer Academic, Boston, M A.

Herzschuh, U., Tarasov, P., Wunnemann, B., Hartmann, K., 2004. Holocene vegetation and climate of the Alashan Plateau, NW China, reconstructed from pollen data. Palaeogeography, Palaeoclimatology, Palaeoecology 211, 1-17.

Herzschuh,U., Winter, K., Wunnemann, B., Li, S., 2006. A general cooling trend on the Central Tibetan plateau throughout the Holocene recorded by the lake Zigetang pollen spectra. Quaternary International 154-155, 113-121. 
Herzschuh, U., 2006. Palaeo-moisture evolution in monsoonal central Asia during the last 50,000 years. Quaternary Science Reviews 25, 163-178.

Hilbig, W.,1995. The vegetation of Mongolia. SPB Academic Publishing, Amsterdam.

Jigjidsuren, S., Johnson, D.A., 2003. Forage plants in Mongolia. Ulaanbaatar: Admon Press.

Jacoby, G., Pederson, N., D’Arrigo, R., 2003. Temperature and precipitation in Mongolia based on dendro climatic investigations. Chinese Science Bulletin, 48, 1474-1479.

Johnstad, M.D., Reading, R.P., 2003. Mongolia's protected areas system. Biodiversity Briefings from Northern Eurasia 2, 8-11.

Johnson, D., Sheehy, D., Miller, D., Damiran, D., 2006. Mongolian range lands in transition. Sécheresse 17, 133-141.

Juggins, S., 2007. C2 version 1.5 User Guide. Soft ware for ecological and palaeoecological data analysis and visualization. University of New castle upon Tyne, Uk.

Kadota T., Davaa G. 2005. Recent glacier variations in Mongolia. Proceedings of the Third International Workshop on Terrestrial Change in Mongolia, 20-22.

Komatsu, G., Brantingham, P., Olsen, J., Baker, V., 2001. Paleoshore line geomorphology of Bo“o”n Tsagaan Nuur, Tsagaan Nuur and Orog Nuur: the Valley of Lakes, Mongolia. Geomorphology 39, 83-98.

Lehmkuhl, F., Haselein, F., 2000. Quaternary palaeo-environmental change on the Tibetan Plateau and adjacent areas (Western China and Western Mongolia). Quaternary International 65-66, 121145.

Li, X., Jie, Z., Ji, S., Chengyu, W., Hongli, Z., Qianli, S., 2004. Vegetation history and climatic variations during the last ka BP inferred from a pollen record at Daihai Lake,north-central China. Review of Palaeobotany and Palynology 132,195- 205.

Li, Y.C., Xu, Q.H., Zhao, Y.K., Yang, X.L., Xiao, J.L., Chen, H., Lu, X. M., 2005. Pollen indication to source plants in the eastern desert of China. Chinese Science Bulletin 50, 1632-1641.

Ma,Y., Liu, K., Feng, Z., Sang, Y., Wang, W., Sun, A., 2008. A survey of modern pollen and vegetation along a south-north transect in Mongolia. Biogeography 35, 1512-1532.

Maher, L.J., 1964. Ephedra pollen in sediments of the great lakes region. Ecology 45, 391-395.

Maygmarjav, B., Davaa, G., 1999. Surface water of Mongolia. Ulaanbaatar: Inter press Publishing.

Moore, P.D., Webb, J.A., Collinson, M. E., 1999. Pollen analysis. Blackwell, Oxford, 2nd. ed.

Nandintsetseg, B., Greene, J, S., Goulden, C.E., 2007. Trends in extreme daily precipitation and temperature near Lake Hovsgol, Mongolia. International Journal of Climatology 27, 34-347.

Owen, L.A., Windley, B.F., Cunningham, W.D., Badamgarav, J., Dorjnamjaa, D., 1997. Quaternary alluvial fans in the Gobi of southern Mongolia: evidence for neo tectonics and climate change. Journal of Quaternary Science 12, 239-252.

Prokopenko, A.A., Khursevich, G.K., Bezrukova, E.V., Kuzmin, M.I., Boes, X., Williams, D.F., Fedenyn, S.A., Kulagina, N.V., Letunova, P., Abzaeva, N., 2007. Paleoenvironmental proxy 
records from lake Hovsgol, Mongolia and a synthesis of Holocene climate change in the lake Baikal watershed . Quaternary research 68, 12-17.

Qin, J.M., Yuan, D.X., Cheng, H., 2005. The Y. D. and climate abrupt events in the early and middle Holocene: Stalagmiter oxygen isotope record from Maolan, Guizhou, China. Science China Series D-Earth Sciences 48, 530-537.

Rudaya, N.A., Tarasov, P.E., Dorofeyuk, N.I., Kalugin, I.A, Andreev, A.A., Diekmann, B., Daryin, A.V., 2008. Environmental changes in the Mongolian Altai during the Holocene. Archaeology, Ethnology and Anthropology of Eurasia 36, 2-14.

Sato, T., Kimura, F. 2006. Regional climate simulations to diagnose environmental changes in Mongolia. Bulletin of the Terrestrial Environment Research Center, University of Tsukuba 7, 59-69.

Schlütz, F., Dulamsuren, C., Wieckowska, M., Mühlenberg, M., Hauck, M., 2008. Late Holocene vegetation history suggests natural origin of steppes in the northern Mongolian mountain taiga. Palaeogeography, Palaeoclimatology, Palaeoecology 261, 203-217.

Shinneman, A., Umbanhowar, C., Edlund, M., Soninkhishig, N., 2010. Late Holocene moisture balance inferred from diatom and lake sediment records in western Mongolia. The Holocene 20, 123-138.

Sun, A., Feng, Z., Ma. Y.Z., 2010. Vegetational and environmental changes in western Chinese Loess Plateau since 13.0 ka BP. Journal of Geographical Sciences 20, 177-192.

Trenberth, K.E., Jones, P.D., Ambenje, P., 2007. Observations: surface and atmospheric climate change. In: Climate Change: The Physcial Science Basis, Cambridge University Press, Cambridge. pp235-336.

Tuvdendorzh, D., Myagmarzhav, B. (eds)., 1985. Atlas of the climate and ground water resources in the Mongolian people's republic. GUGMS, Ulaan Bator.

Van Geel, B., Buurman, J., Brinkkemper, O., Schelvis, J., Aptroot, A., van Reenen, G., Hakbijl, T., 2003. Environmental reconstruction of a roman Period settlement site in Uitgeest (Netherlands), with special reference to coprophilous fungi. Journal of Archaeological Science 30, 873-883.

Vanky, K., 1994. European smut fungi.Gustav Fischer Verlag,Stuttgart. New York.

Walter, H., 1974. Die Vegetation Osteuropas, Nord- und Zentralasiens. Fischer, Stuttgart, Germany.

Wang, W., Feng, Z., Lee, X., Zhang, H., Ma, Y., An, C., Guo, L. 2004. Holocene abrupt climate shifts recorded in Gun Nuur lake core, northern Mongolia. Chinese Science Bulletin 49, 520-526.

Wang, Y., Cheng, H., Edwards, R.L., He, Y., Kong, X., An, Z., Wu, J., Kelly, M.J., Dykoski, C.A., Li, X., 2005. The Holocene Asian Monsoon: Links to Solar Changes and North Atlantic Climate. Science 308, 854-857. 
Wang, S.Y., Lu, H.Y., Liu, J.Q., Jorg, F.W., 2007. The early Holocene optimum inferred from a high resolution pollen record of Huguangyan Maar Lake in southern China. Chinese Science Bulletin 52, 2829- 2836.

Wang, W., Ma, Y.Z., Feng, Z.D., Meng., H.W., Sang, Y.L., Zhai, X., 2009. Vegetation and climate changes during the last 8660 cal. a BP in central Mongolia based on a high-resolution pollen record from lake Ugii Nuur. Chinese Science Bulletin 54, 1579-1589.

Weninger, B., Jöris, O., 2008. A ${ }^{14} \mathrm{C}$ age calibration curve for the last $60 \mathrm{ka}$ : the Greenland-Hulu U/Th timescale and its impact on understanding the Middle to Upper Paleolithic transition in Western Eurasia. Journal of Human Evolution 55, 772-781.

Yang, X., Rost, K.T., Lehmkuhl, F., Zhenda, Z., Dodson, J., 2004. The evolution of dry lands in Northern China and in the Republic of Mongolia since the Last Glacial Maximum, Quaternary International, 118-119, 69-85.

Yu, G., Prentice, I.C., Harrison, S.P., Sun, X., 1998. Pollen-based biome reconstruction for China at 0 and 6000 years. Journal of Biogeography 25, 1055-1069.

Zhao, Y., Yu, Z., Chen F., Ito, E., Zhao, C., 2007. Holocene vegetation and climate history at Hurleg Lake in the Qaidam Basin, North West China. Review of Palaeobotany and Palynology 145, 275-288. 


\title{
Chapter 2
}

\section{First high resolution palynological record of climate history in the late Quaternary from the high continental Gobi desert of Mongolia}

\author{
Waheed Murad, Frank Schlütz, Thomas Felauer, Steffen Mischke and Frank Lehmkuhl
}

Vegetation History and Archaeobotany (under review)

\begin{abstract}
A $5 \mathrm{~m}$ long high resolution pollen and non-pollen palynomorphs (NPP) of the Bayan Tohomiin Nuur (BTN), an almost dry lake in the Gobi desert of Mongolia, reveals a detailed history of the significant continental vegetation, environmental and climate change from about 15.3 to $3.8 \mathrm{ka}$ cal B.P. Located in a semi-arid desert-steppe adjoining the desert today, pollen of Artemisia, Chenopodiaceae but also of the Ephedra distachya-type are abundant in the recovered sediments. Four semi-arid phases (Artemisia values $40-60 \%$ ) of about 2.5 to $3 \mathrm{ka}$ cal B.P. length were interrupted by arid spells (Chenopodiaceae $40-50 \%, \mathrm{~A} / \mathrm{C}$ ratio $<2$ ) of 0.4 to $1.2 \mathrm{ka}$ cal B.P. duration. During the arid phases high values of the Glomus-type (10 - 20\%) indicates a stronger terrigenous input into the lake by erosion, reaching down into the rhizosphere of sparse catchment vegetation. A contemporaneous spreading of Ephedra shrubs is related to barren grounds. The first arid phase (12.3 -11.1 ka cal B.P.) correlates most probably with the Younger Dryas and the second one (8.6 - 7.6 cal B.P.) with the $8.2 \mathrm{ka}$ event. An early short and slight climatic deterioration possibly reflects the Oldest Dryas. The most stable and relatively moist conditions (Artemisia steppe) occurred in the middle Holocene from 6.3 to 4.9 ka cal B.P. These inferences point to a climatic synchronicity with the Younger Dryas and $8.2 \mathrm{ka}$ event of northern hemisphere and most posibly a stronger moisture input by the westerlies which probably caused the mid-Holocene climate optimum.

Pollen of trees, shrubs, grazing weeds, and spores of coprophilous and plant infecting fungi are present only in low quantities. Fossil eggs of the intestinal parasite Trichuris are reported for the first time from Mongolia.

Our results demonstrate the potential of pollen analysis on well selected small catchment archives to improve the current state of knowledge with respect to the climate history of Mongolia.
\end{abstract}

Key words: Mongolia, Gobi desert, Holocene, pollen, non-pollen palynomorphs

\section{Introduction}

Mongolia is situated in the heart of continental Asia and is in need of special attention from palaeoecologists and palynologists as reconstructions of the late Quaternary vegetation and environment are still sparse and regionally restricted. Studies have been carried out mostly in the 
northwest of Mongolia (Gunin et al. 1999). The older publications summarized in Gunin et al. (1999) are originally published in Russian. Most of the more recent palaeoecological studies are also restricted to northern Mongolia, while the desert and steppe regions in the south are sparsely investigated (Fig. 2.1). Tarasov et al. (2000a) and Rudaya et al. (2009) reconstructed the Holocene environmental changes around the Hoton Nuur (Nuur meaning lake) in the Mongolian Altai in the northwest of Mongolia.

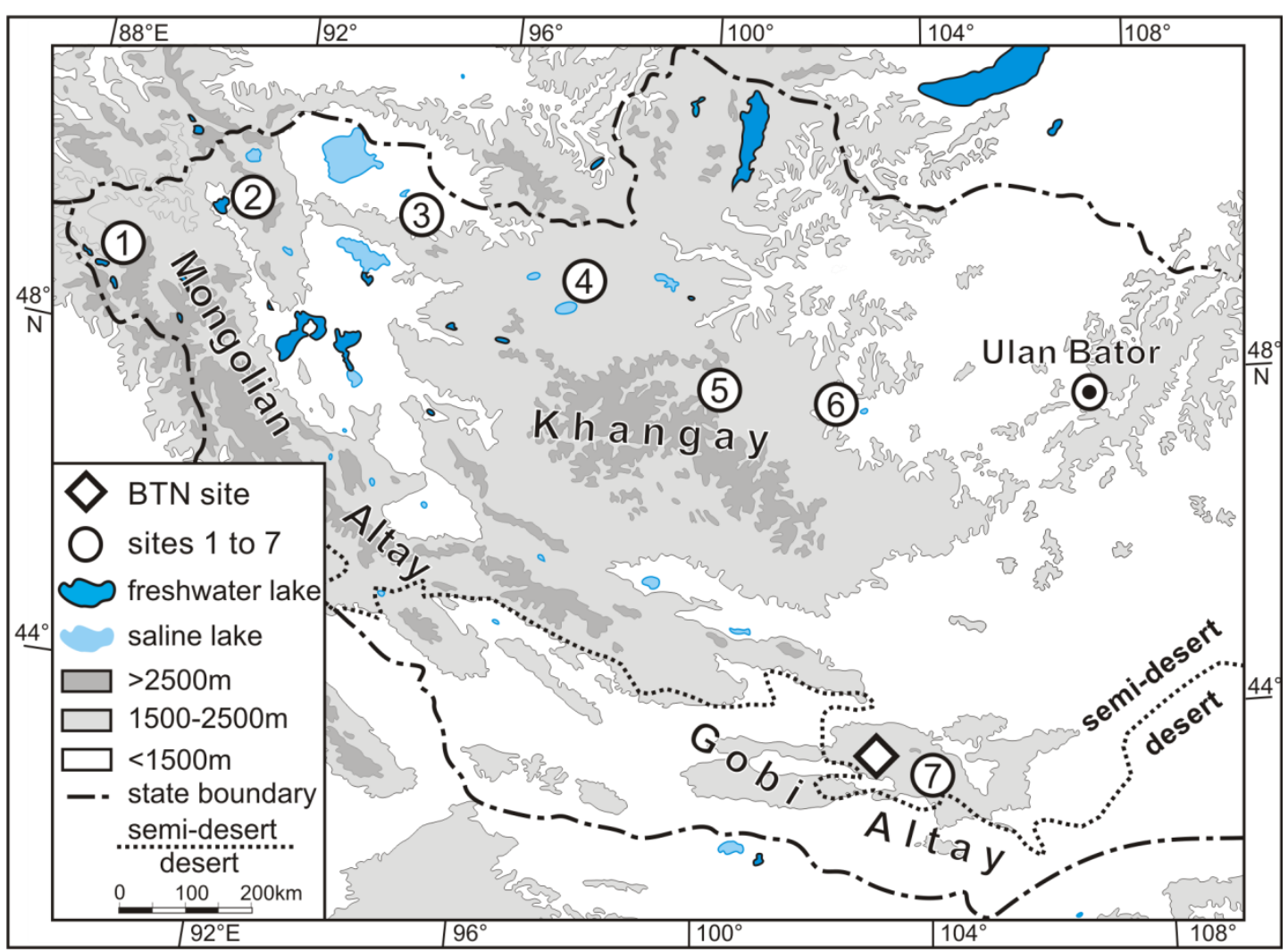

Fig. 2.1: Map of Mongolia with investigation site, sites mentioned in the text and the transition line from desert to semi-desert (Artemisia steppe). Sites mentioned in the text include: 1. Hoton Nuur (Tarasov et al., 2000 / Rudaya et al., 2009) 2. Archit Nuur (Gunin et al., (eds.) 1999) 3. Bayan Nuur (Grunert et al., 2000) 4. Telmen Nuur (Fowell et al., 2003 / Peck et al., 2002) 5. Daba Nuur (Gunin et al., (eds.) 1999) 6. Ugii Nuur (Wang et al., 2009, 2011 / Schwanghart et al., 2008, 2009) 7. Yolin Am (Miehe et al., 2007)

Fowell et al. (2003) and Peck et al. (2002) worked on mid to late Holocene climate evolution at the Telmen Nuur in north-central Mongolia. Wang et al. $(2009,2011)$ investigated a Holocene vegetation and climate history record from the Ugii Nuur in central Mongolia. The same archive was studied by Schwanghart et al. (2008, 2009). The Last Glacial Maximum (LGM), mid Holocene and modern biomes have been reconstructed by Tarasov et al. (1999a, 1999b, 2000b) for the territory of the former Soviet Union and Mongolia based on pollen and plant macrofossils. Until now some of the local 
results seem to contradict each other (Herzschuh, 2006), which may be due to a complex interplay of climatic influences changing over time from westerlies and summer monsoon as well as difficult geological and geomorphological features of the mainly vast catchment areas of the hitherto studied archives.

The lack of palaeoecological knowledge is most severe in the very dry southern part of Mongolia with missing up-to-date analyses. The Bayan Tohomiin Nuur (BTN) studied here occupies a small catchment area of only $1750 \mathrm{~km}^{2}$ in the desert-steppe zone of southern Mongolia close to the Gobi desert. Due to its unique geographical location and small catchment area its sediments are a sensitive archive for vegetation and climate change. Here we present pollen and NPP records indicating several climatic fluctuations in the late Quaternary (15.3 to $3.8 \mathrm{ka}$ cal B.P.). A detailed discussion of the sedimentological data is already published (Felauer et al. 2012). The closest palynological study was carried out on a terrestrial profile from the Gobi Altai (2390 m asl.) less than $100 \mathrm{~km}$ away comprising about the last $5 \mathrm{ka}$ cal B.P. (Miehe et al. 2007).

\section{Modern climate and vegetation}

It is a general belief that Central Asia is slowly drying out (Wesche et al. 2005) but recent dendroclimatological studies suggest unchanged or even increasing annual precipitation for Mongolia in the $20^{\text {th }}$ century (Jacoby et al. 2000). Because of the distance to the oceans, the climate is strongly continental with high yearly temperature amplitudes and relatively low precipitation.

Mountain barriers in the west and north-west intercept atmospheric flows bringing moisture from the west, while the moisture carrying East Asian summer monsoons fade rapidly in the very south-east of Mongolia. In the south the country is open to dry desert winds from Central Asia (Gunin et al. 1999). The present climate of the study area is semi-arid and extremely continental. The short growing season is limited in spring by low precipitation and by frost from September to May. Typical for desert regions, the precipitation varies strongly between years (Wesche et al. 2005). The winters are controlled by the Siberian-Mongolian high pressure cell, causing pronounced dryness with about only $10 \%$ of the mean annual precipitation. In spring time moisture is brought with strong winds from westerly directions. The altering influence of westerlies and the East Asian summer monsoon causes higher rates of rainfall (Feng et al. 2005). The mean annual precipitation is below $150 \mathrm{~mm}$. The climate stations nearest the BTN (1420 m asl.) Dalandzadgad (1470 m asl.) and Bayandalay (1570 m asl.) recorded annual precipitations of $131 \mathrm{~mm} / \mathrm{a}$ and $110 \mathrm{~mm} / \mathrm{a}$ respectively. The mean temperatures are estimated for January at around $-15^{\circ} \mathrm{C}$ and for July at $>20^{\circ} \mathrm{C}$ (Geographic Atlas of Mongolia 2004; Wesche et al. 2005).

Mongolia is a transitional zone between the Siberian taiga and the deserts of Central Asia. The majority of its territory is covered by steppes and desert-steppes. Five main vegetation zones mostly running from west to east are recognized along a south-north transect (Hilbig 1995; Hilbig and Opp

2003; Ma et al. 2008; Wesche et al. 2005, von Wehrden et al. 2006). Desert vegetation occupies the 
Gobi in the south between 750 to $1200 \mathrm{~m}$ asl. including low shrubs and semi shrubs of the Chenopodiaceae (Anabasis, Haloxylon, Kalidium, Kochia, Nanophyton, Salsola), Artemisia, Calligonum, Nitraria, Ephedra and Convolvulus. The zone to the north with a mean annual precipitation between 100 to $150 \mathrm{~mm}$ is mostly covered by an Artemisia-Stipa desert-steppe with Poaceae (Stipa krylovii, S. gobi, Cleistogenes soongrica) and subshrubs of several species of Artemisia and Tanacetum. Steppe vegetation is found in the majority of central and eastern Mongolia where the annual precipitation reaches 150 to $300 \mathrm{~mm}$ and is mainly dominated by grasses like Stipa capillata and Cleistogenes squarrosa and partly Artemisia (A. frigida). A forest steppe zone is distributed in altitudes above the grass steppe at about $1000-1600 \mathrm{~m}$ asl. where the effective moisture is higher. This zone is a patchwork of forests in mostly northern expositions of Larix sibirica with some Betula and Pinus sylvestris in a grass steppe (Stipa krylovii, Poa attenuate). A zone of mountain taiga with Larix sibirica and Pinus sibirica reaches up to over 2000 m elevation. Alpine vegetation occurs only in relatively restricted areas. Any zone of deciduous forests between conifer forests and steppe such as is found in most of Eurasia is not developed in Mongolia (Hilbig 1995; Walter 1975).

\section{Materials and methods}

A sediment core was obtained from the nearly dried-out BTN in the easternmost part of the Gobi Altai, southern Mongolia, at 43 $34^{\prime} 23.8^{\prime \prime} \mathrm{N}$ and $103^{\circ} 11^{\prime} 38.2^{\prime \prime} \mathrm{E}$ ( $1420 \mathrm{~m}$ asl.). An extended lake existed here in a wide flat intramontane basin, which shrank during the later Holocene. The endorhehic catchment area covers about $1750 \mathrm{~km}^{2}$ with ephemeral streams. The former extent of the lake is marked by a belt of small sand dunes fixed by Achnatherum splendens and a sandbar at about $9 \mathrm{~m}$ above the recent lake level (Grunert et al. 2009). A salt-meadow evolved on the gray silty lake sediments, covering the area at the core site.

A core of $5 \mathrm{~m}$ length was drilled from 2 to $7 \mathrm{~m}$ depth below surface. The upper $2 \mathrm{~m}$ of the core was unconsolidated and was not suitable for pollen analyses. In total 56 palynological samples of 0.5 or 1 $\mathrm{cm}^{3}$ were taken in 5 to $10 \mathrm{~cm}$ intervals. Sample preparation was carried out with standard methods (Erdtman 1960; Moore et al. 1999) including treatment with $\mathrm{HCl}, \mathrm{KOH}$, $\mathrm{HF}$ and acetolysis. Lycopodium spores were added as exotic marker to calculate the concentration (pollen grains $/ \mathrm{cm}^{3}$ ) and influx of pollen (pollen grains $/ \mathrm{cm}^{2} / \mathrm{yr}$ ) and carbonized particles as well. The suspensions were sieved in an ultrasonic bath through a $1.5 \mu \mathrm{m}$ mesh and stored in glycerin.

More than 400 pollen grains plus NPPs were counted for each sample and all percentages were calculated based on the sum of terrestrial pollen. Three samples $(388,550,659 \mathrm{~cm})$ contained less pollen grain (pollen sums 313, 269, 337). Pollen and spore types were identified with the reference collections of the Department of Palynology and Climate Dynamics at the University of Göttingen and relevant publications (Beug 2004; Moore et al. 1999; Van Geel et al. 2003; Van Geel and Aptroot 2006; Vanky 1994). Pollen clumps, denoting immature pollen grains sticking together, were recorded as an additional palaeoecological proxy (Schlütz and Lehmkuhl 2007). 
The software $\mathrm{C} 2$ version 1.5.1 was used to present the selected palynological data as diagrams (Juggins, 2007). All observed palynological taxa occurring at least three times or with values of more than $0.5 \%$ are presented. The taxa are arranged according to their ecology and chronological appearance.

\section{Stratigraphy and chronology}

The core sediment consists of lacustrine fine silt $(60-70 \%)$ and clay $(25-35 \%)$, partly mixed with layers of coarse silt and fine sand. The sand fraction remains almost low $(<5 \%)$. At the base $(700-326$ $\mathrm{cm})$ the sediments are black and show faint lamination while the top $(326-200 \mathrm{~cm})$ is gray consisting of homogenous units with weak horizontal bedding.

Nine Accelerator mass spectrometry (AMS) ${ }^{14} \mathrm{C}$ measurements were completed on the TOC of bulk samples, as remains of terrestrial plants were very scarce or absent (Tab. 2.1). A first set consisting of two subsets of 2 samples each processed at the AMS-Laboratory of Erlangen University (Erl.) revealed

\begin{tabular}{|c|c|c|c|c|c|}
\hline Depth [cm] & Lab. No & $\begin{array}{c}{ }^{14} \mathrm{C} \text { age and } \\
\text { error [yr. BP] }\end{array}$ & $\delta^{13} \mathrm{C}[\%$ ] & $\begin{array}{c}\text { calibrated } \\
\text { age and SD } \\
{[\text { cal. yr. BP] }}\end{array}$ & material \\
\hline 247 & Poz-37868 & $5495 \pm 35$ & $-21,3$ & $6299 \pm 24$ & bulk sample \\
\hline 253 & Erl-13181 & $5880 \pm 46$ & -20.5 & $6709 \pm 45$ & bulk sample \\
\hline 353 & Erl-12109 & $8697 \pm 56$ & -22.7 & $9674 \pm 85$ & bulk sample \\
\hline 367 & Poz-37949 & $9270 \pm 50$ & $-25,1$ & $10441 \pm 88$ & bulk sample \\
\hline 367 & Poz-37869 & $9320 \pm 60$ & $-24,6$ & $10523 \pm 90$ & bulk sample \\
\hline 526 & Erl-13182 & $6037 \pm 47$ & -21.6 & $6884 \pm 64$ & bulk sample \\
\hline 536 & Poz-37870 & $6920 \pm 40$ & $-26,8$ & $7222 \pm 36$ & bulk sample \\
\hline 674 & Erl-12110 & $10661 \pm 56$ & -23.3 & $12661 \pm 65$ & bulk sample \\
\hline 665 & Poz-37871 & $11170 \pm 70$ & $-27,4$ & $13073 \pm 125$ & bulk sample \\
\hline
\end{tabular}

Tab. 2.1: Results of the AMS ${ }^{14} \mathrm{C}$-datings and their calendric age-conversion (calibration) with $1 \sigma$ standard deviation (SD) using "CalPal-online" (Weninger and Jöris 2008)

Source: Felauer et al., 2012

a time inversion at $353 \mathrm{~cm}$. A control set of 4 samples from about the same depths analyzed in the Poznan Radiocarbon Laboratory (Poz.) confirmed the previous results, with the doubtful sample (here $367 \mathrm{~cm}$ ) being measured twice. All dates were calibrated with the online version of the program CalPal (Weninger and Jöris 2008).

To frame a sound age-depth model several possible influences on the measured ages should be assessed. One possible factor obscuring the real age of a given sample is the reservoir effect caused by old carbon incorporated by photosynthetic active water plants. As reported from Central Asia this can lead to an age overestimation of a few hundred to about 2000 years or more (Feng et al. 2005; Jiang et 
al. 2006; Rickettsa et al. 2001). In the catchment area of the BTN carbonate rocks as a source of old carbon are unknown. Moreover, the BTN was probably always a large and flat lake with $\delta^{13} \mathrm{C}$ of dissolved inorganic carbon in equilibrium with the atmosphere due to intense $\mathrm{CO}_{2}$ exchange. Therefore, the results of AMS dating are probably not affected by the lake reservoir effect. Furthermore the low $\delta 13 \mathrm{C}$ values point to carbon of terrestrial origin, as large proportions of water plants would lead to high $\delta 13 \mathrm{C}$ values (Herzschuh et al. 2005, Stuiver and Polach 1977). For this reason a remarkable reservoir effect may be rejected.

A source of old carbon could be land snails whose shells occurred at about $360 \mathrm{~cm}$ depth but not within the range of the other samples for radiocarbon dating. The deepest datings could be influenced by carbon of redeposit fossils like foraminifera whose liners occurred between 640 and $690 \mathrm{~cm}$. As a source of old carbon redeposited "charcoals" (Fig. 4: burnt plant fragments) should be taken in to account. Neglecting the doubtful ages of about $10 \mathrm{ka} \mathrm{cal} \mathrm{B.P.} \mathrm{around} 360 \mathrm{~cm}$ depth would result in an unrealistically high sedimentation rate (300 $\mathrm{cm}$ in less than 1000 years), that is lacking evidence in the sediment parameters (see Felauer et al. 2011 for detail) including the suitable high pollen concentration. Possibly the upper-most sample was influenced by modern carbon from the roots of the salt meadows leading to an age underestimation.

As clear conclusions are masked by the described, and possibly other, reasons, we used the radiocarbon dates without a reservoir or other corrections to establish a rather conservative age-depth model. Assuming a relatively young retreat of the flat lake, the surface level was included with its recent age. Because the time inversion prevents linear interpolation, a polynomial graph (Fig. 2.2) best fitting to the latest data set (Poz. 37868 - Poz. 37871) was chosen. The corresponding time frames of the BTN zones show convincing correlations to known events of climate history. This is for instance true for the length and timing of BTN $2(12.3$ - 11.1 ka cal B.P.), representing a dry period quite possibly equivalent to the Younger Dryas event as well as for the dry spell of BTN 4 (8.6 - $7.55 \mathrm{ka} \mathrm{cal}$ B.P.) that seems to represent the $8.2 \mathrm{ka}$ event (this will handled in more detail in the discussion). Apparantly the contradicting influences of different sources of error seem to balance each other more or less.

\section{Results and interpretation}

About 80 different types of pollen and NPP (spores, algae, eggs) have been identified. Artemisia, Chenopodiaceae and Ephedra distachya-type are the most abundant with marked oscillations of amounts throughout the sediment core. Together they constitute more than $70 \%$ of the total pollen sum of each sample. The diagrams (Fig. 2.3) are divided into seven local zones (BTN 1 - 7) mainly based on changes in the Artemisia/Chenopodiaceae (A/C) ratio. The borders between zones are drawn 


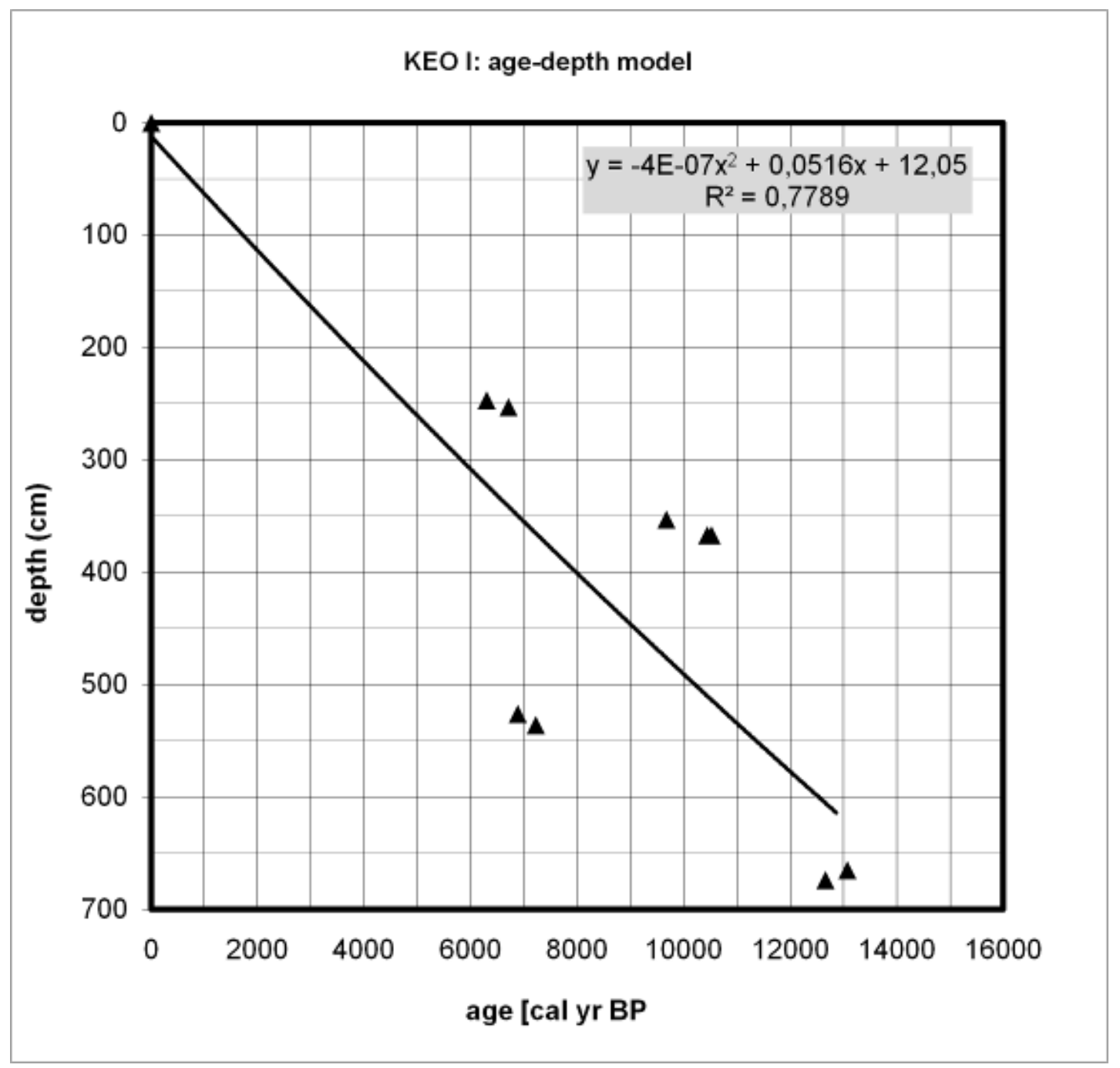

Fig. 2.2: Age-depth model of the Bayan Tohomiin Nuur site based on a polynomial graph best fitting to the calibrated latest data set (Poz. 37868 - Poz. 37871). Source: Felauer et al., 2012

where the $\mathrm{A} / \mathrm{C}$ ratio exceeds values of about 2 . The zones BTN 1, 3, 5 and 7 are characterized by high Artemisia values and consequently high A/C ratios. Zones BTN 2, 4 and 6 show high Chenopodiaceae values and $\mathrm{A} / \mathrm{C}$ ratios below 1 coinciding with a prominent amount of the Glomus-type spores. In BTN 4 and 6 the Ephedra distachya-type rises up to $40 \%$ and $65 \%$ respectively. Pollen of trees and shrubs is very rare, with single taxa reaching 1\% (Hippophae, Salix, Betula, Ulmus, Pinus Haploxylon- and Pinus Diploxylon-type). 


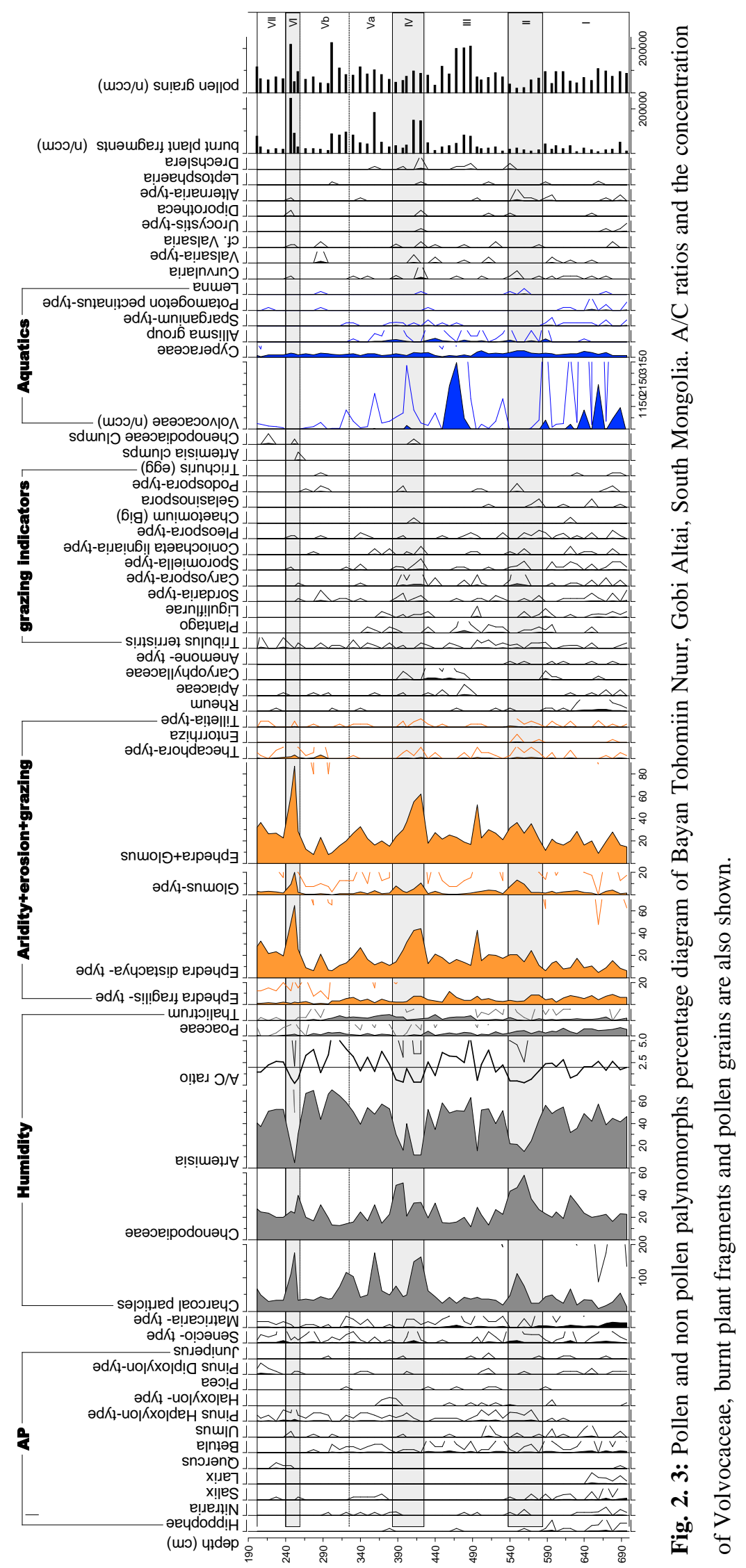




\section{BTN 1, 700 - 585 cm, 15.3 - 12.3 ka cal B.P.: Relatively dry Artemisia desert-steppe}

Artemisia (45\%), Chenopodiaceae (24\%), the Ephedra distachya- (10\%) and the Ephedra fragilis-type $(6 \%)$ are the dominant pollen taxa. This and intermediate $\mathrm{A} / \mathrm{C}$ ratios around 2 point most probably to an open Artemisia desert-steppe rich in Ephedra shrubs with Chenopodiaceae deserts nearby. The relatively high Ephedra distachya-/Ephedra fragilis-type ratios (Ef/Ed ratios) point to Ephedra species growing under dry conditions (Herzschuh 2007, Schlütz and Lehmkuhl 2007, Tarasov et al. 1996). With Poaceae values around 5\%, Stipa and other grasses must have been of very low regional abundance. The Glomus-type spore, representing spores of mycorrhiza fungi, indicate that soils were eroded down into the rhizosphere (Miehe et al. 2009). Around $13.5 \mathrm{ka}$ cal. B.P. a fall of the A/C ratios to values around 1 indicating a short expansion of desert.

Nitraria shrubs spread near the lake on sandy sites with brackish ground water and a few small trees and shrubs of Hippophae and Salix along the temporal rivers as well (Grubov 2001; Hilbig 1995). The BTN investigation site is situated at the western limit of the recent area of Ulmus pumila and a few trees with contact to the groundwater may have grown along the river beds in the region already 15,000 years ago (Wesche et al. 2011). Pollen of others trees and shrubs are more probably of long distance transport origin.

Beside the climate also grazing animals and fires (burnt plant fragments) affect the plant diversity. Low values of pollen from grazing weeds (Tribulus terrestris, Liguliflorae, Plantago), spores of corpophilous ascomycetes (Sordaria-, Sporormiella- and Podospora-type) and eggs of the intestinal parasite Trichuris reflect the presence of herbivores around the lake (Van Geel and Aptroot 2006, Miehe et al. 2007, 2009). Their diet, herbaceous plants and grasses, were affected by several species of smut fungi (Thecaphora-, Tilletia-, Urocystis-type) (Miehe et al. 2009; Vanky 1994).

The high peaks of Volvocaceae probably indicates phases of mesotophic to eutrophic lake conditions with high organic productivity due to stronger nutrient input (Chen et al. 2003; Jin et al. 2006; Kramer et al. 2010; Feleauer et al. 2012). Pollen of aquatic plants (Potamogeton pectinatus-, Sparganium-type, Allisma group) and Poaceae point to submerged plants of shallow water and reed beds as found recently at the shore of the Orog Nuur, about $250 \mathrm{~km}$ to the north-west (Hilbig 1995).

\section{BTN 2, 585 - 538 cm, 12.3 - 11.1 ka cal B.P.: Arid Chenopodiaceae desert}

Highest Chenopodiaceae values of the record (58\%), decreasing Artemisia percentages $(<25 \%)$ and consequently low A/C ratios (0.5) indicate arid conditions. The increase in Ephedra distachya-type (>10\%) points to colder conditions and possible barren rocks with Ephedra shrubs growing in their crevices (Herzschuh 2007, Schlütz and Lehmkuhl 2007). Soil erosion due to the sparse vegetation is indicated by higher values of the Glomus-type (up to 13\%) and the occurrence of spores of Entorrhiza, a smut fungi genus with species infecting the roots of Cyperaceae and Juncaceae. As indicated by the lowering of the Ef/Ed ratio the erosion increased under somewhat cooler climatic conditions. 
Ascomycetes (Coniochaeta ligniaria-type) were probably involved in the subaerial decay of woody material, and water ascomycetes of the genus Caryospora or relatives (Caryospora-type) probably enhanced decay within the lake after subaqueous deposition. . The absence of Potamogeton pectinatustype points to a shrunken or more salty lake with a decreased productivity indicated by lower values of TOC and $\mathrm{CaCO}_{3}$ (see Feleauer et al. 2012 for detail).

\section{BTN 3, 538 - $430 \mathrm{~cm}, 11.1$ - 8.6 ka cal B.P.: Semi-arid Artemisia steppe}

A steep rise of Artemisia ( $>50 \%$ ) and a strong reduction of Chenopodiaceae (A/C $\sim 4)$, indicate a semiarid Artemisia desert steppe again. A rise of Thalictrum may hint to the development of meadowsteppe-like vegetation types under more humid conditions in higher altitudes (Grubov 2001). Reduced amounts of $\mathrm{Fe}$, Ti, Glomus-type and $\mathrm{Rb} / \mathrm{Sr}$ and $\mathrm{K} / \mathrm{Ca}$ ratios are evidence for a quite dense vegetation cover (see Feleauer et al. 2012 for detail). Few reversals of these erosion and detrital influx-indicators coincident with high amounts of Volvocaceae, TOC and N. High N values combined with a low persistence of Glomus-type point to the in wash of nutrient rich litter and/or topsoil.

\section{BTN 4, 430 - $383 \mathrm{~cm}, 8.6$ - 7.6 ka cal B.P.: Chenopodiaceae desert with Ephedra shrubs}

The climatic conditions became arid again (low A/C ratios). A first phase characterized by exceptionally high values of the Ephedra distachya-type (>40\%) represents the time of a very open vegetation cover with areas of barren ground dominated by Ephedra shrubs. A deep reaching soil erosion is demonstrated by the Glomus-type. In a second phase, shrubs of Ephedra were partly replaced by Chenopodiaceae, but erosion remained high. Intermediate cooler conditions indicated by almost disappearing Thalictrum values (meadow-steppes at higher elevations) in the second part of the BTN 4 could have caused the Ephedra shrub phase. Nevertheless, Ephedra distachya-type percentages of more than (10-) 20\% are hard to interpret as they have no recent analogs in Mongolia (Ma et al. 2008), Inner Mongolia (Liu et al. 2006; Wang et al. 1996) as well as in other parts of Central Asia (Herzschuh 2007; Tarasov et al. 1998; Yu et al. 2001). Thus further research on surface samples is needed for a more sound palaeoecological understanding.

\section{Zone BTN 5, 383 - $260 \mathrm{~cm}, 7.6$ - 4.9 ka cal B.P.: Most wet with Artemisia desert-steppe to steppe}

A sharp rise in the Artemisia percentages demonstrates again a rapid change from arid to semi-arid conditions. The zone can be divided into two sub zones. In the beginning (BTN 5a) the landscape status resembles very much that of BTN 3 (Artemisia desert-steppe). At around $6.3 \mathrm{ka} \mathrm{cal} \mathrm{B.P.} \mathrm{(325}$ $\mathrm{cm}$ ) the start of the rise of the Artemisia curve to over 70\% (A/C >4) marks the onset of the most stable and humid conditions for the entire sediment core, possibly representing a semi-humid Artemisia steppe in BTN 5b. Very low values of erosion indicator (Glomus-type) suggest a dense vegetation cover. The soil stabilization during this climatic amelioration was in contrast to the other relatively less arid periods of BTN 3 and BTN 5a. Nevertheless, synchronously occurring slightly higher values of 
Chenopodiaceae and Ephedra distachya-type (one sample) and a reduced carbonate precipitation (two samples) may point to a short lived cold event without notable long-term consequences for erosion.

The dense vegetation offered a substantial food supply for the existing herbivores (Tribulus terrestris, Podospora-type, Trichuris) lowering the relative grazing pressure. This and/or a change in composition or density of the herbivore fauna may have led to the lasting reduction of typical grazing weeds such as Liguliflorae and Plantago.

\section{BTN 6, 260 - $240 \mathrm{~cm}, 4.9$ - 4.5 ka cal B.P.: Cool and arid Ephedra shrub vegetation}

Highest values of Ephedra distachya- (65\%) and Glomus-type (20\%) for the entire record show that the loss of soil by erosion and the portion of barren ground reached probably their greatest extents. High concentrations of burnt plant particles point to frequent fires under dry climatic conditions (A/C ratio 0.2). The same is true for BTN 4. Such fires may have significantly supported the abundance of

Ephedra shrubs. However, concurrent extremely high concentrations of burnt plant particles and pollen grains could be the result of an unobstructed surface runoff (Hartmann and Wünnemann 2009). Also the occurrence of pollen clumps in the sediment may be a result of water transport. Overall, the ecological conditions resembled those in the first phase of BTN 4, with BTN 6 being probably too short for a subsequent succession to a Chenopodiaceae desert.

\section{BTN 7, 240 - $200 \mathrm{~cm}, 4.5$ - 3.8 ka cal. B.P.: Relatively dry Artemisia desert-steppe}

$\mathrm{A} / \mathrm{C}$ ratios around 2 and high Artemisia abundance imply a relatively dry Artemisia desert-steppe as in BTN 1, which was slightly richer in Ephedra shrubs. Parallel to the increase of the Ephedra distachya-type, the (aeolian) clastic input grew ( $\mathrm{Ti}, \mathrm{Fe}$ ) once more. Very low values of grazing indicators possibly result from a strongly reduced animal population. As spores of coprophilous fungi are dispersed only over very short distances, higher values may denote to water transport, thus lower values may point to the drying out of the lake.

\section{Discussion}

Regarding the given age-depth model, the recorded alteration of arid, semi-arid and semi-humid climatic conditions correlate well to the traits of supraregional climatic patterns (Tab. 2.2). 


\begin{tabular}{|c|c|c|c|c|}
\hline $\begin{array}{c}\text { BTN } \\
\text { zone } \\
\text { S }\end{array}$ & $\begin{array}{l}\text { Time period } \\
\text { (Ka cal. B.P.) }\end{array}$ & Vegetation and sedimentological derivations & Climate & $\begin{array}{l}\text { Duration } \\
\quad(\mathrm{ka})\end{array}$ \\
\hline 7 & $4.5-3.8$ & $\begin{array}{l}\text { Artemisia desert-steppe with Ephedra shrubs, } \\
\text { erosion low, lake shrinking }\end{array}$ & semi-arid & 0.7 \\
\hline 6 & $4.9-4.5$ & $\begin{array}{l}\text { Ephedra shrub dominated Chenopodiaceae } \\
\text { desert, Glomus-type, erosion very high }\end{array}$ & (cold-)arid & 0.4 \\
\hline $\begin{array}{l}5 \mathbf{b} \\
\mathbf{5 a}\end{array}$ & $\begin{array}{l}6.3-4.9 \\
7.6-6.3\end{array}$ & $\begin{array}{l}\text { dense Artemisia steppe, erosion lowest } \\
\text { Artemisia desert-steppe with Ephedra shrubs, } \\
\text { erosion relative low }\end{array}$ & $\begin{array}{l}\text { semi-humid } \\
\text { semi-arid }\end{array}$ & $\begin{array}{l}1.4 \\
1.3\end{array}$ \\
\hline 4 & $8.6-7.6$ & $\begin{array}{l}\text { succession from a Ephedra shrub land to a } \\
\text { Chenopodiaceae desert, Glomus-type, erosion high }\end{array}$ & $\begin{array}{l}\text { warm-arid } \\
\text { cold-arid }\end{array}$ & 1.0 \\
\hline 3 & $11.1-8.6$ & Artemisia desert-steppe, erosion low & semi-arid & 2.5 \\
\hline 2 & $12.3-11.1$ & $\begin{array}{l}\text { Chenopodiaceae desert with Ephedra shrubs, } \\
\text { Glomus-type, erosion high }\end{array}$ & (cold)-arid & 1.2 \\
\hline 1 & $15.3-12.3$ & $\begin{array}{l}\text { Artemisia desert-steppe with few Ephedra shrubs, } \\
\text { low erosion }\end{array}$ & semi-arid & 3.0 \\
\hline
\end{tabular}

Tab. 2.2: Synopsis of vegetation, landscape and climate evolution at the Bayan Tohomiin Nuur site, Gobi Altai, South Mongolia

\section{Late Glacial}

The record starts at about $15.3 \mathrm{ka}$ cal. B.P. with the pollen-based reconstruction of a relatively dry Artemisia desert-steppe near to Chenopodiaceae deserts lasting until about $12.3 \mathrm{ka}$ cal. B.P. (BTN 1). This period was followed by a pronounced climatic deterioration (BTN 2), suggesting that the BTN 1 may be the high continental equivalent of the late glacial stadials Meiendorf, Bölling and Alleröd known from northern Europe and north-east China as phases of forest reestablishment and increased $\delta^{18} \mathrm{O}$ values in ice cores from Greenland (Litt and Stebich 1999, Stebich et al. 2009). This lateglacial warm period lasted in NE-China until $12.5 \mathrm{ka}$ cal. B.P. (Schettler et al. 2006).

With 1200 years of arid conditions the BTN 2 (12.3 - $11.1 \mathrm{ka}$ cal. B.P.) apparently corresponds to the Younger Dryas period which is represented by a dry phase in most parts of Central Asia lasting from about 12.8 to $11.5 \mathrm{ka}$ cal. B.P. (Herzschuh 2006) and marked by a forest decline in north-east China dated by warved sediments to 12.7 to $11.65 \mathrm{ka}$ cal. B.P. (Stebich et al. 2009). The relative delay of the BTN 2 of about 400-500 years can be ascribed to uncertainties in the age-depth model. A short return to dry conditions in the BTN 1 at around $13.5 \mathrm{ka}$ cal. B.P. possibly correlate to the colder and/or dryer Oldest Dryas (13.9 - 13.8 ka cal B.P.) occurring in north-east China, where an Older Dryas equivalent (ca. 13.5 ka cal. B.P.) was not recorded so far (Stebich et al. 2009). 


\section{Holocene}

The Holocene is mostly represented by relatively humid conditions interrupted by dryer oscillations (Tab. 2.2). The early Holocene starts at about $11.1 \mathrm{ka}$ cal. B.P. with a climatic amelioration lasting almost 2500 years (BTN 3). These more humid conditions coincide with the onset of higher effective moisture in continental Asia at around $11.5 \mathrm{ka}$ cal. B.P. due to an abrupt intensification of the summer monsoon system driven by a steep rise in air temperature as documented in Greenland ice cores (Herzschuh 2006). A strengthening of the North Atlantic Oscillation enhanced the westerlies drawing more moisture from the sea to the interior of Eurasia. Thus the effective moisture in Central Asia increased due to strong westerlies and an enhanced summer monsoon as well (Morrill et al. 2003; Qin and Yu, 1998; Tarasov and Harrison 1998; Wang et al. 2004).

Wang et al. (2007) also discussed an enhanced summer monsoon at about $11 \mathrm{ka}$ cal B.P. in India, western Asia, western Africa and the Sahara, placing the moisture-driven climatic optimum into the early Holocene. In contrast to monsoon-controlled areas, the early Holocene in the Gobi Altai was not the period of maximum moisture availability. However, the temperatures increased in all mentioned areas as well as in northern Eurasia (Andreev and Tarasov, 2007) and the precipitation must have been notably higher in the early Holocene compared to the cooler conditions of the BTN 1 to result in relatively high effective moisture.

The semi-arid conditions during the early Holocene were followed by an abrupt climatic deterioration from 8.6 to $7.6 \mathrm{ka}$ cal. B.P. (BTN 4). The vegetation succession from Ephedra shrubs to a Chenopodiaceae desert points to a climatic shift from more cold and dry to warm and dry conditions. This succession can be Probably related to some extent to the 8.2 ka event known from the Greenland ice cores as a strong climatic reversal lasting about 150 years (Kobashi et al. 2007; Thomas et al. 2007). The $8.2 \mathrm{ka}$ event was the middle part of a longer climate deterioration of 400 to 600 years (Jin et al. 2007; Lal et al. 2007; Prasad et al. 2006; Rohling et al. 2005; Wang et al. 2005). Despite the dating uncertainties, the relatively long period of 1000 years and the climatic evolution reflected at the BTN site may be peculiarities under a high continental climate.

The abrupt change to moister conditions marks the onset of a mid-Holocene climatic amelioration lasting from 7.6 to $4.9 \mathrm{ka}$ cal. B.P. (BTN 5). Following the review of Feng et al. (2006), the western part of southern Mongolia experienced a generally wet climate from 7.5 to $4.0 \mathrm{ka}$ cal B.P. (Chinese province Xinjiang). To the east of Mongolia in the Chinese province Inner Mongolia a dry early Holocene was followed by a wet middle Holocene from 7.4 to $4.5 \mathrm{ka}$ cal. B.P. as well. In contrast, in the south of Mongolia this period was dry (Feng et al. 2006; Chen et al. 2003). In northern Mongolia, a drought took place between 6.5 to $4.8 \mathrm{ka}$ cal B.P. (An et al. 2008) and in NE-China the summer monsoonal rainfall reached a minimum at around $6.4 \mathrm{ka}$ cal B.P. (Schettler et al. 2006). Extreme spatial climate differences in Central Asia during the Holocene were already pointed out earlier (i.e. An et al. 2008, Herzschuh 2006). With the help of the new information from the BTN area a supraregional pattern characterized by a relatively wet belt stretching west-east over more than $30^{\circ}$ of 
latitude and a few hundred kilometers south-north bordered by dry regions in the north and south may be derived. Possibly the confluence of westerly and monsoonal air masses led to atmospheric and resulting precipitation while in the south and north the sole marginal influence of each of these two climate systems was relatively weak (Feng et al. 2005). Thus the asynchronous climate developments in the region were the result of a complex and combined influence of the westerlies and the monsoon (Jiang et al. 2007; Schettler et al. 2006).

The most humid phase inferred from our record lasted from 6.3 to $4.9 \mathrm{ka} \mathrm{cal}$. B.P. (BTN 5b) and was characterized by a well proliferated Artemisia steppe which represents the Holocene climate optimum in the Gobi Altay. This is in accordance with the rising lake level of the Telmen Nuur between 6.3 and 4.4 ka cal. B.P. (Peck et al. 2002) and the maximum of tree pollen at the Bayanchagan lake in Inner Mongolia some $1000 \mathrm{~km}$ east of the BTN (Jiang et al. 2006). As the monsoonal influence in Asia decreased since at least $7 \mathrm{ka}$ cal. B.P. the moisture optimum in the Gobi Altai must have been steered by northern hemispheric processes (An et al. 2000; Herzschuh et al. 2006; Jiang et al. 2006; Li et al. 2004). The climatic optimum was suddenly terminated by a short climatic reversal to arid and possibly colder conditions from 4.9 to $4.5 \mathrm{ka} \mathrm{cal}$. B.P. (BTN 6). A minimum in the summer monsoon rainfall in NE-China at around $4.9 \mathrm{ka}$ cal. B.P. (Schettler et al. 2006) and a hiatus in the sediments of the Bayanchagan lake (Jiang et al. 2006) point to an temporal regional moisture deficit during this time. At least the subsequent 700 years (BTN 7) were semi-arid again.

Some of the climatic changes can be correlated to the climate of the northern hemisphere pointing to teleconnections with the North Atlantic (Chen et al. 2010, Vandenberghe et al. 2006). For instance, the increase in moisture from the westerlies depends on an increase in evaporation over the north Atlantic driven by a higher summer insolation (Feng et al. 2006). As the summer monsoon is also controlled by orbital forcing, coeval changes took place. Thus not all observed changes in the BTN record can be attributed to one or the other climate system, as also links between the North Atlantic and the summer monsoon regions exist (Gupta et al. 2003, Wang et al. 2005).

\section{Conclusions}

The palynological record of the Bayan Tohomiin Nuur of southern Mongolia Gobi desert revealed a detailed history of vegetation and landscape dynamics in high continental Asia from about 15.3 to 3.8 ka cal BP. The reconstructed climatic phases can be correlated within dating errors to typical features of the Northern Europe climate patterns such as the Younger Dryas and the 8.2 ka event. A midHolocene timing of the moisture optimum is attributed to a strengthening of the westerlies. Nevertheless the combined influence of westerlies and the summer monsoon caused a relatively humid phase just before the Holocene optimum, while bordering areas in the south and north were dry.

The overall high correlation with supraregional climate dynamics seems to be a peculiarity of the BTN record, while most of the Mongolian archives stress small-scale differences obscuring outreaching commonalities to some extent. We can conclude that the small catchment area of the BTN, its location 
at the transition from desert to semi-desert and the shallow character of the lake led the sediments of the BTN to become a highly sensitive and representative archive for climate and landscape change. Our results emphasize the need for further detailed interdisciplinary studies of well selected archives of Mongolia to contribute to a decryption of the complex spatial patterns of climate history in central Asia

\section{Acknowledgments}

The present work is a contribution to the project "Late Pleistocene, Holocene and ongoing geomorphodynamics in the Gobi Desert; South Mongolia" (LE 730/16-1) funded by the German Research Foundation (Deutsche Forschungsgemeinschaft, DFG). The authors acknowledge the Higher Education commission (HEC), Pakistan and Kohat University of Science and Technology, Kohat (KUST), Pakistan for financial support for radiocarbon dating and palynological analysis. We wish to thank the Mongolian Academy of Sciences (Prof. D. Dorjgotov, A. Tschimegsaichan and Serd-Yanjiv Narangerel) for support during the field work. We sincerely thank Dr. Jean Nicolas Haas for kind help in identification of Volvocaceae.

\section{References}

ADMINISTRATION OF LAND AFFAIRS, G.A.C (2004) Geographic Atlas of Mongolia.Ulaanbaatar.

An C, Chen F, Barton L (2008) Holocene environmental changes in Mongolia: A review. Global and Planetary Change 63: 283-289

Andreev AA, Tarasov PE (2007) Post glacial pollen records of Northern Asia. Encyclopedia of Quaternary Science. Elsevier, pp 2721-2730

Beug HJ (2004) Leitfaden der Pollenbestimmung für Mitteleuropa und angrenzende Gebiete, Pfeil Verlag, München

Chen H, Song S, Lee T, Löwemark L, Chi Z, Wang Y (2010) A multiproxy lake record from Inner Mongolia displays a late Holocene teleconnection between central Asian and north Atlantic climate. Quaternary International, doi number:10.1016/j.quaint.2010.03.005.

Chen F, Wu W, Holmes J, Madsen D, Zhu Y, Jin M, Oviatt C (2003) A mid-Holocene drought interval as evidenced by lake desiccation in the Alashan Plateau Inner Mongolia China. Chinese Science Bulletin 48 (14): 1401-1410

Erdtman G (1960) The acetolysis method. Svensk Botanisk Tidskrift 54: 561-564

Feng Z, Wang WG, Guo LL, Khosbayar P, Narantsetseg T, Jull AJT, An CB, Li XQ, Zhang HC, Ma YZ (2005) Lacustrine and eolian records of Holocene climate changes in the Mongolian Plateau: Preliminary results. Quaternary International 136: 25-32

Feng Z, An C, Wang H (2006) Holocene climatic and environmental changes in the arid and semi-arid areas of China: A review. The Holocene 16: 119-130 
Felauer T, Schlütz F, Murad W, Mischke S, Lehmkuhl F (2012) Late Quaternary climate and landscape evolution in central Asia: A multiproxy study of lake archive Bayan Tohomiin Nuur, Gobi desert,southern Mongolia. Journal of Asian Earth Sciences 48:125-135

Fowell S, Hansen B, Peck JA, Khosbayar P, Ganbold E (2003) Mid to late Holocene climate evolution of the lake Telmen Basin North Central Mongolia based on palynological data. Quaternary Research 59: 353-363

Grubov V (2001) Key to the Vascular plants of Mongolia. Vol. 1+2. Science publication Enfield

Grunert J, Stolz C, Hempelmann N, Hilgers A, Hülle D, Lehmkuhl F, Felauer T, Dasch D (2009) The evolution of small lake basins in the Gobi desert in Mongolia. Quaternary Sciences, Beijing. (Submitted)

Gunin PD, Vostokova EA, Dorofeyuk NI, Tarasov PE, Black CC (1999) Vegetation dynamics of Mongolia. Geobotany 26, pp. 233-238. Kluwer Academic Boston MA

Gupta AK, Anderson DM, Overpeck JT (2003) Abrupt changes in the Asian southwest monsoon during the Holocene and their links to the North Atlantic Ocean. Nature 421: 354-357

Hartmann K, Wünnemann B (2009) Hydrological changes and Holocene climate variations in NW China inferred from lake sediments of Juyanze palaeolake by Factor analysis. Quaternary International 194: 28-44

Herzschuh U, Zhang C, Mischke S, Herzschuh R, Mohammadi F, Mingram B, Kürschner H, Riedel F (2005) A late Quaternary lake record from the Quilian Mountains (NW China): Evolution of the primary production and the water depth reconstructed from macrofossil pollen biomarker and isotope data. Global and Planetary Change 46: 361-379

Herzschuh U (2007) Reliability of pollen ratios for environmental reconstructions on the Tibetan Plateau. Journal of Biography 34: 1265-1273

Herzschuh U (2006) Palaeo-moisture evolution in monsoonal Central Asia during the last 50,000 years. Quaternary Science Reviews 25: 163-178

Herzschuh U, Kürschner H, Mischke S (2006) Temperature variability and vertical belt shifts during the last $\sim 50000 \mathrm{yr}$ in the Qilian Mountains (NE margin of the Tibetan Plateau), China. Quaternary Research 66: 133-146

Hilbig W (1995) The vegetation of Mongolia. SPB Academic Publishing Amsterdam

Hilbig W, Opp C (2003) Verbreitungsregeln von Böden und Pflanzengesellschaften im nördlichen Zentralasien unter besonderer Berücksichtigung des Uvs-Nuur-Beckens. Petermanns Geographische Mitteilungen 147:16-23

Jacoby GC, D'Arrigo RD, Pederson N, Buckley BM, Dugarjav C, Mijiddorj R (2000) Temperature and precipitation in Mongolia based on dendro-climatic investigations. IAWA Journal 20 (3): 339-350 
Jiang W, Guo Z, Sun X, Wu H, Chu G, Yuan B, Hatte C, Guiot J (2006) Reconstruction of climate and vegetation changes of lake Bayanchagan (Inner Mongolia): Holocene variability of the east Asian monsoon. Quaternary Research 65: 411-420

Jiang Q, Shen J, Liu X, Zhang E, Xiao X (2007) A high-resolution climatic change since Holocene inferred from multi-proxy of lake sediment in westerly area of China. Chinese Science Bulletin 52: 1970-1979

Jin Z, Li F, Cao J, Wang S, Yu J (2006) Geochemistry of Daihai Lake sediments Inner Mongolia north China: Implications for provenance sedimentary sorting and catchment's weathering. Geomorphology 80: 147-163

Jin Z, Yu J, Chen H, Wu Y, Wang S, Chen S (2007) The influence and chronological uncertainties of the $8.2 \mathrm{ka}$ cooling event on continental climate records in China. The Holocene 17: 10411050

Juggins S (2007) C2 version 1.5 User Guide software for ecological and palaeoecological data analysis and visualization .University of New castle upon Tyne UK

Kobashi T, Severinghaus Jeffrey P, Brook Jeffrey P, Brook EJ, Barnola Jean- Marc, Grachev JeanMarc, Grachev AM (2007) Precise timing and characterization of abrupt climate change 8200 years ago from air trapped in polar ice. Quaternary Science Reviews 26: 1212-1222

Kramer A, Herzschuh U, Mischke S, Zhang C (2010) Late Quaternary environmental history of the south-eastern Tibetan plateau inferred from the lake Naleng non-pollen palynomorphs record. Vegetation History and Archaeobotany 19: 453-468

Lal D, Large WG, Walker SG (2007) Climatic forcing before, during and after the $8.2 \mathrm{Ka}$ yr BP global cooling event. Journal of Earth System Science 116: 171-177

Li X, Jie Z, Ji S, Chengyu W, Hongli Z, Qianli S (2004) Vegetation history and climatic variations during the last 14 ka BP inferred from a pollen record at Daihai Lake north-central China. Review of Palaeobotany and Palynology 132: 195-205

Liu H, Wang Y, Tian Y, Zhu J, Wang H (2006) Climatic and anthropogenic control of surface pollen assemblages in East Asian steppes. Review of Palaeobotany and Palynology 138: 281 - 289

Litt T, Stebich M (1999) Bio- and chronostratigraphy of the late Glacial in the Eifel region, Germany.

Quaternary International 61: 5-16

Ma Y, Liu K, Feng Z, Sang Y, Wang W, Sun A (2008) A survey of modern pollen and vegetation along a south-north transect in Mongolia. Biogeography 35:1512-1532

Miehe G, Schlütz F, Miehe S, Opgenoorth L, Cermak J, Samiya E, Jager EJ, Wesche K (2007) Mountain forest islands and Holocene environmental changes in Central Asia: A case study from the Southern Gobi Altay Mongolia. Palaeogeography, Palaeoclimatology, Palaeoecology 250: $150-166$ 
Miehe G, Miehe S, Kaiser K, Reudenbach C, Behrendes L, La Duo, Schlütz F (2009) How old is Pastoralism in Tibet? An Ecological approach to the making of a Tibetan landscape. Palaeogeography, Palaeoclimatology, Palaeoecology 276: 130-147

Mischke S, Demske D, Schudack E (2003) Hydrologic and climatic implications of a multidisciplinary study of the mid to late Holocene Lake Eastern Juyanze. Chinese Science Bulletin 48: 1411-1417

Morrill C, Overpeck JP, Cole JE (2003) A synthesis of abrupt changes in the Asian summer monsoon since the last deglaciation. The Holocene 13 (4): 465-476

Moore PD, Webb JA, Collinson ME (1999) Pollen analysis. Blackwell Oxford 2nd. Ed.

Peck JA, Khosbayar P, Fowell SJ, Pearce RB, Ariunbileg S, Hansen BCS, Soninkhishig N (2002) Mid to late Holocene climate change in north central Mongolia as recorded in the sediments of lake Telmen. Palaeogeography, Palaeoclimatology, Palaeoecology 183: 135-153

Prasad S, Brauer A, Rein B, Negendank JFW (2006) Rapid climate change during the early Holocene in Western Europe and Greenland. The Holocene 16: 153-158

Qin B, Yu G (1998) Implications of lake level variations at 6 and $18 \mathrm{ka}$ in mainland Asia. Global and Planetary Change 18: 59-72

Rohling EJ, Palike H (2005) Centennial-scale climate cooling with a sudden cold event around 8200 years ago. Nature 434: 975-979

Rickettsa RD; Johnsona TC; Brown ET; Rasmussen KA; Romanovsky VV (2001) The Holocene paleolimnology of lake Issyk-Kul, Kyrgyzstan: Trace element and stable isotope composition of ostracodes. Palaeogeography, Palaeoclimatology, Palaeoecology 176: 207-227

Rudaya N, Tarasov P, Dorofeyuk N, Solovieva N, Kalugin I, Andreev A, Diekmann B, Riedel B, Tserendash N, Wanger M (2009) Holocene environments and climate in the Mongolian Altai reconstructed from the Hoton-Nuur pollen and diatom records: A step towards better understanding climate dynamics in Central Asia. Quaternary Science Reviews 28 (5-6): 540554

Schettler G, Liu Q, Mingram J, Stebich M, Dulski P (2006) East-Asian monsoon variability between 15000 and $2000 \mathrm{cal}$ yr BP recorded in varied sediments of lake Sihailongwan (Northeastern China Long Gang volcanic field). The Holocene16: 1043-1057

Schwanghart W, Schütt B, Walther M (2008) Holocene Climate Evolution of the Ugii Nuur Basin, Mongolia. Advances in Atmospheric Sciences 25: 986-998

Schlütz F, Lehmkuhl F (2007) Climatic change in the Russian Altai southern Siberia based on palynological and geomorphological results with implications for climatic teleconnections and human history since the middle Holocene. Vegetation History and Archaeobotany 16: 101118 
Stebich M, Mingram J, Han J, Liu J (2009) Late Pleistocene spread of (cool-) temperate forests in Northeast China and climate changes synchronous with the North Atlantic region. Global and Planetary Change 65: 56-70

Stuiver M, Polach H A (1977) Discussion reporting 14C data. Radiocarbon 19:355-363

Tarasov PE, Pushenko M, Harrison SP, Saarse L, Andreev AA, Aleshinskaya ZV, Davydova NN, Dorofeyuk NI, Efremov YV, Elina GA, Elovicheva YK, Filimonova LV, Gunova VS, Khomutova VI, Kvavadze EV, Neustreuva IYu, Pisareva VV, Sevastyanov DV, Shelekhova TS, Subetto DA, Uspenskaya ON, Zernitskaya VP (1996) Lake status records from the former Soviet Union and Mongolia: Documentation of the Second Version of the Database. NOAA Palaeoclimatology Publications Series Report Boulder CO vol. 5 pp 224

Tarasov PE, Harrison SP (1998) Lake status records from the former Soviet Union and Mongolia. Documentation of the Second Version of the Database. World Data Center-A for Palaeoclimatology, Boulder, Colorado

Tarasov PE, Cheddadi R, Guiot J, Bottema S, Peyron O, Belmonte J, Ruiz-Sanchez V, Saadi FA, Brewer, S (1998) A method to determine warm and cool steppe biomes from pollen data; application to the Mediterranean and Kazakhstan Regions. Journal of Quaternary Science 13 (4): $335-344$

Tarasov PE, Peyron O, Guiot J, Brewer S, Volkova VS, Bezusko LG, Dorofeyuk NI, Kvavadze EV, Osipova IM, Panova NK (1999a) Last Glacial Maximum climate of the former Soviet Union and Mongolia reconstructed from pollen and plant macrofossil data. Climate Dynamics 14: 227-240

Tarasov PE, Guiot J, Cheddadi R, Andreev AA, Bezusko LG, Blyakharchuk TA, Dorofeyuk NI, Filimonova LV, Volkova VS, Zernitskaya VP (1999b) Climate in Northern Eurasia 6000 years ago reconstructed from pollen data. Earth and Planetary Science Letters 171: 635645.

Tarasov P, Dorofeyuk N, Metel'tseva E (2000a) Holocene vegetation and climate changes in HotonNuur basin North West Mongolia. Boreas 29: 117-126

Tarasov PE, Volkova S, Webb T, Guiot J, Andreev AA, Bezusko LG, Bezusko TV, Bykova GV, Dorofeyuk NI, Kvavadze EV, Osipova IM, Panova NK, Sevastyanov DV (2000b) Last Glacial maximum biomes reconstructed from pollen and plant macrofossil data from Northern Eurasia. Journal of Biogeography 27: 609-620

Thomas ER, Wolff Eric W, Mulvaney R, Steffensen Jorgen P, Johnsen SJ, Arrowsmith Carol, White JWC, Vaughn B, Popp T (2007) The 8.2 ka event from Greenland ice cores. Quaternary Science Reviews 26: 70-81 
Van Geel B, Buurman J, Brinkkemper O, Schelvis J, Aptroot A, van Reenen G, Hakbijl T (2003) Environmental reconstruction of a roman period settlement site in Uitgeest (Netherlands ) with special reference to coprophilous fungi. Journal of Archaeological Science 30: 873-883

Van Geel B, Aptroot A (2006) Fossil ascomycetes in Quaternary deposits. Nova Hedwigia 82:313-329

Vandenberghe J, Renssen H, van Huissteden K, Nugteren G, Konert M, Lu H, Dodonov A, Buylaert J (2006) Penetration of Atlantic westerly winds into Central and East Asia. Quaternary Science Reviews 25: 2380-2389

Vanky K (1994) European smut fungi. Fischer Verlag Stuttgart, New York

Von Wehrden H, Hilbig W, Wesche K (2006) Plant communities of the Mongolian Transaltay Gobi. Feddes Repertorium 117: 526-570

Walter H (1974) Die Vegetation Osteuropas, Nord- und Zentralasiens. Fischer, Stuttgart

Wang FY, Song CQ, Sun XJ (1996) Study on surface pollen in middle Inner Mongolia, China. Acta Botanica Sinica 38: 902-909

Wang W, Feng Z, Lee X, Zhang H, Ma Y, An C, Guo L (2004) Holocene abrupt climate shifts recorded in Gun Nuur lake core northern Mongolia. Chinese Science Bulletin 49: 520-526

Wang Y, Cheng H, Edwards RL, He Y, Kong X, An Z, Wu J, Kelly MJ, Dykoski CA, Li X (2005) The Holocene Asian Monsoon: Links to Solar Changes and North Atlantic Climate. Science 308 : 854-857

Wang SY, Lu HY, Liu JQ, Jorg FW (2007) The early Holocene optimum inferred from a high resolution pollen record of Huguangyan Maar lake in southern China. Chinese Science Bulletin 52: 2829-2836

Wang W, Ma YZ, Feng ZD, Meng HW, Sang YL, Zhai XW (2009) Vegetation and climate changes during the last $8660 \mathrm{cal}$ a BP in central Mongolia based on a high-resolution pollen record from lake Ugii Nuur. Chinese Science Bulletin 54: 1579-1589

Wang W, Ma YZ, Feng ZD, Narantsetseg T, Liu KB, Zhai X (2011) A prolonged dry mid-Holocene climate revealed by pollen and diatom records from Lake Ugii Nuur central Mongolia. Quaternary International 229: 74-83

Weninger B, Jöris O (2008) A ${ }^{14} \mathrm{C}$ age calibration curve for the last $60 \mathrm{ka}$ : The Green land-Hulu U/Th time scale and its impact on understanding the middle to upper Paleolithic transition in Western Eurasia. Journal of Human Evolution 5: 772-781

Wesche K, Miehe S, Miehe G (2005) Plant communities of the Gobi Gurvan Sayhan National Park (South Gobi Aymak Mongolia) Candollea 60: 149-205

Wesche K, Walther D, von Wehrden H, Hensen I (2010) Trees in the desert: Reproduction and genetic structure of fragmented Ulmus pumila forests in Mongolian drylands. Flora 206: 91-99

Yu G, Tang L, Yang X, Ke X, Harrison S (2001) Modern pollen samples from alpine vegetation on the Tibetan Plateau. Global Ecology and Biogeography 10: 503-519 


\title{
Chapter 3
}

\section{Late Quaternary climate and landscape evolution in arid Central Asia: A multiproxy study of lake archive Bayan Tohomin Nuur, Gobi desert, southern Mongolia}

\author{
Thomas Felauer $^{\mathrm{a}, *}$, Frank Schlütz ${ }^{\mathrm{b}, \mathrm{c}}$, Waheed Murad $^{\mathrm{b}, \mathrm{d}}$, Steffen Mischke $^{\mathrm{e}}$, Frank Lehmkuhl ${ }^{\mathrm{a}}$ \\ Journal of Asian Earth Sciences 48 (2012) 125-135
}

\begin{abstract}
A $7 \mathrm{~m}$ sediment core from the Bayan Tohomin Nuur dry lake located in southern Mongolia was investigated by a multidisciplinary study to reconstruct the history of climate and palaeoenvironmental conditions during the late Quaternary. The geochemical, granulometric, palynological and ostracod results show a graduation of at least nine climatic units during the last $15 \mathrm{ka}$ cal. BP. The climate during the late Glacial changed from wet towards more dry conditions, representing the beginning of the Younger Dryas period. At $11 \mathrm{ka}$ cal. BP a rise in temperature and precipitation could be reconstructed, marking the onset of the Holocene. The humid period of the Holocene lasted until about $4 \mathrm{ka} \mathrm{cal}$. BP, interrupted by shorter dry/cold reversals at $8.5-7.5 \mathrm{ka}$ cal. BP and $5-4.5 \mathrm{ka}$ cal. BP. The aridity in southern Mongolia increased afterwards accompanied by the strengthening of aeolian processes, dune remobilization and lake desiccation.
\end{abstract}

Keywords: paleoclimate, sedimentology, palynology, late Pleistocene, Holocene

\section{Introduction}

In paleoclimate research lake sediments have proved to serve as good archives for reconstruction of climatic changes during the Pleistocene and Holocene. Due to the low disturbance and the evident stratification of many lacustrine sediments paleoenvironmental conditions may be reconstructed using continuously accumulated lake sediment archives.

On two expeditions in the years 2007 and 2008, lacustrine sediment cores were taken at three different sites (Bayan Tohomiin Nuur, Khongoryn Els, Orog Nuur) in order to reconstruct environmental and climatic processes in the basins of the northern Gobi. In this paper we present our findings concerning the sedimentary and geochemical evolution of the Bayan Tohomiin Nuur area during the transition from Pleistocene to Holocene. The Bayan Tohomiin Nuur dry lake is located in continental Central Asia (Mongolia) in the present transition zone between the Gobi desert and desert-steppe, therefore representing a very valuable archive sensitive to past climatic changes. The multiproxy analysis of the $7 \mathrm{~m}$ core included the investigation of geochemical, granulometric, palynological and ostracod analyses used to reconstruct the geomorphologic, climatic and sedimentary processes within the small 
local catchment of the lake during the last $13 \mathrm{ka}$. Detailed palynological analyses of the core are in preparation. Therefore only selected palynological results are presented here.

Investigations of the late Pleistocene climatic development focused mainly on the northern parts of Mongolia, analyzing changes in lake levels, deposition of glacial sediments, phases of aeolian activity and the spreading of vegetation (Lehmkuhl 1997, Lehmkuhl, 1998, Naumann 1999, Walther 1999, Grunert et al. 2000, Schlütz 2000, Tarasov 2000, Peck et al. 2002, Fowell et al. 2003, Walther et al. 2003, Grunert and Lehmkuhl 2004, Wang et al. 2004, Prokopenko et al. 2007, Gilespie et al. 2008). These surveys concluded that a moist and relatively cold climate prevailed between about 45-30 ka. During that time many lakes in northern Mongolia maintained high lake levels (Walther 1999, Grunert and Dasch 2000, Grunert et al. 2000, Lehmkuhl and Lang 2001). Between 25 ka and 13 ka arid-cold conditions prevailed in most parts of Central Asia as reconstructed from low lake levels, vegetation changes, dust deposition, dune formation and glacier advances (Owen et al. 1997, Owen et al. 1998, Walther 1999, Fedotov et al. 2000, Grunert et al. 2000).

Holocene climate reconstructions show regional variations and uncertainties and the differentiation between local signals and regional climatic patterns is difficult (Fowell et al. 2003, Chen et al. 2008). At the Uvs Nuur basin two Holocene phases of high lake levels were reconstructed for the periods from 11.2-9.6 ka and 7.3-3.2 ka (Walther 1999, Grunert and Dasch 2000, Grunert et al. 2000). Peck et al. (2002) and Fowell et al. (2003) inferred a general rise in lake level at Telmen Nuur during the Holocene. At lake Ugii Nuur humid conditions were reconstructed from sedimentological analyses for 7.9-4.2 ka and $2.8 \mathrm{ka}$ (Schwanghardt et al. 2008), whereas Wang et al. 2009 reconstructed based on pollen analyses a dry and warm climate between 8-3.2 ka and 1.6-0 ka for Central Mongolia interrupted by wet and cold conditions. Investigations on paleosoils in loess sections (northern Mongolia) indicate humid and warm conditions at around 6 ka and $3 \mathrm{ka}$ (Feng et al. 2005, Lehmkuhl unpubl. data).

Paleoclimatic research in southern Mongolia has only rarely been conducted. Investigations of beach bars of Orog Nuur and Adgiyn Tsagaan Nuur show low lake levels between 25-15 ka (Komatsu et al. 2001). High lake levels were reconstructed between 10-6 ka and 1.5-1.4 ka (Komatsu et al. 2001, Lehmkuhl and Lang 2001, Yang et al. 2004). Degradation of permafrost during the Holocene was analyzed in alluvial fan sediments of the Gobi Altai by Owen et al. (1998). The formation of alluvial fans in the Gobi was discussed by Owen et al. (1997), Lehmkuhl (2000) and Vassallo et al. (2005). The sediment core at the Bayan Tohomiin Nuur therefore provides further data to improve the understanding of paleoclimate development in southern Mongolia during the Holocene.

\section{Regional setting}

Bayan Tohomiin Nuur dry lake $\left(43^{\circ} 34^{\top} \mathrm{N}, 103^{\circ} 11^{\prime} \mathrm{E}, 1410 \mathrm{~m}\right.$ a.s.l.) is situated in the northwestern Gobi desert within a small NW-SE striking basin (area $\sim 300 \mathrm{~km}^{2}$ ) at the eastern termination of the Khongoryn Els dune field (Fig. 3.1). The basin is framed by NW-SE striking mountain ranges, which 
are part of the Gurvan Saihan island arc terrane. These ranges are composed of Silurian and Devonian metasedimentary rocks, being elevated during Cenozoic faulting as part of the Bogd-Fault system. They consist of left lateral strike-slip and thrust faults (Mineral Resources Authory of Mongolia 1998).

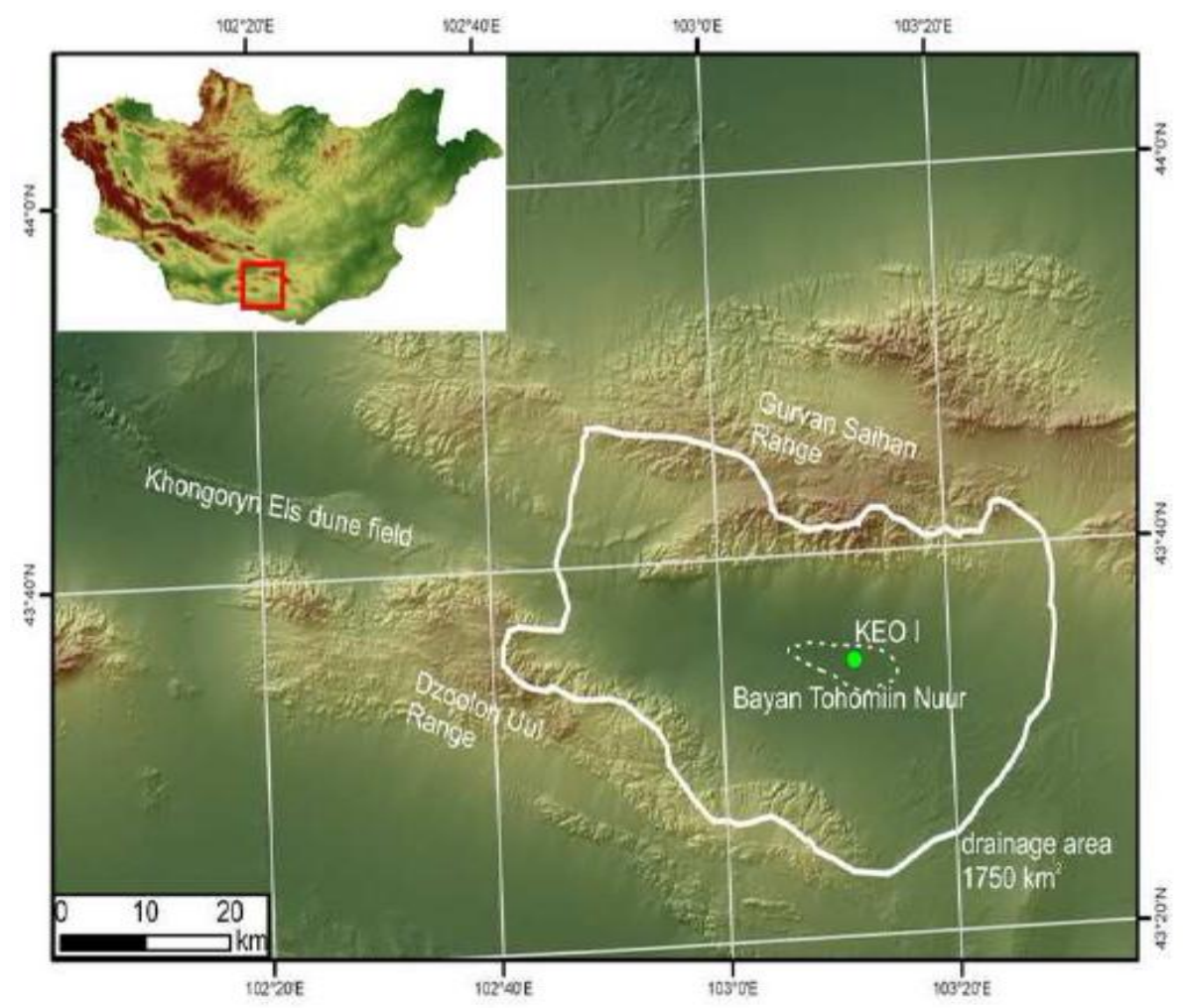

Fig. 3.1: Location of the Bayan Tohomiin Nuur core; the dashed line illustrates the lake area and the bordered line shows the drainage area of the lake

Surrounding mountains reach altitudes of $2600 \mathrm{~m}$ a.s.l. at the northern Gurvan Saihan Range and 2400 $\mathrm{m}$ a.s.l. at the southern Dzoolon Uul Range. The mountain front is covered by several relief generations of alluvial fans and fanglomerates (20-30 km length) building the transition to the endorheic basin, filled with Quaternary sediments. The basin sediments are composed of lacustrine silt and clay, alternating with fluvial slope deposits and aeolian sediments. The Khongoryn Els dune field originates from a large basin located $150 \mathrm{~km}$ to the north-west and covers the bottom of a graben with an area of approximately $1000 \mathrm{~km}^{2}$ and an extent of $180 \mathrm{~km}$. The Khongoryn Els is characterized by several generations of complex dunes reaching up to $100 \mathrm{~m}$ height (Baasan 2004). At the eastern expiration of the Khongoryn Els, the dunes decrease and pass into the lacustrine sediments of Bayan Tohomiin Nuur.

The catchment of the Bayan Tohomiin Nuur occupies an area of $1750 \mathrm{~km}^{2}$, consisting of ephemeral streams prograding from the ranges and alluvial fans into the basin. Due to the low amount of precipitation and the high evaporation the basin is mostly dried up, leaving a salt meadows area at the center mostly fed by groundwater from the alluvial fans. The dried lake area is surrounded by a belt of 
small dunes $(<2 \mathrm{~m}$ ) fixed by Achnatherum splendens (Poaceae). A beach bar at $9 \mathrm{~m}$ above the present surface marks a former expansion of the lake area (Grunert et al. 2009).

Present climate is extremely continental with a high amplitude of mean temperatures ranging from - 15 ${ }^{\circ} \mathrm{C}$ in January to $21{ }^{\circ} \mathrm{C}$ in July. Rainfall is highly variable with mean annual precipitation rates of 127 $\mathrm{mm}$ (National Statistical Office of Mongolia 2004). During the winter months the climate is influenced by the Siberian-Mongolian high pressure cell, which causes low temperatures and dryness (only 10\% of the mean annual rainfall). The alternating occurrence of the East-Asian summer monsoon and westerlies during the summer months causes high temperatures and higher rates of precipitation (Feng et al. 2005).

The vegetation within the catchment area is characterized by desert steppe species of Artemisia and Chenopodiaceae, thus indicating the transition to the desert in the southern part of Mongolia (Barthel 1988, Administration of Land Affairs 2004).

\section{Materials and methods}

A $7 \mathrm{~m}$ core (KEO I) was taken with a percussion corer (Nordmeyer GmbH \& Co. KG, Germany) within the northern margin of the former lake basin $\left(43^{\circ} 34 \mathrm{~N}, 103^{\circ} 11 \mathrm{E}, 1410 \mathrm{~m}\right.$ a.s.l.) during an expedition in August 2007. From the unconsolidated upper $200 \mathrm{~cm}$ ten samples (10 cm thickness) were taken at the coring site. The lower drilled sediments $(700-201 \mathrm{~cm})$ were transported in plastic tubes to RWTH Aachen University where they were opened with an oscillating saw, cleaned and visually described. The drilling was stopped due to technical reasons and deeper lake sediments have to be expected. XRF, grain size, $\mathrm{CaCO}_{3}, \mathrm{CNS}$ and total organic carbon (TOC) were analyzed at RWTH Aachen University on one half of the core. Palynological analyses and extraction of samples for ostracod analysis was done on the second half of the core at the Georg-August University Göttingen.

Element concentrations of $\mathrm{Ti}, \mathrm{Mn}, \mathrm{Fe}, \mathrm{V}, \mathrm{Rb}, \mathrm{Ca}, \mathrm{Sr}$ and $\mathrm{K}$ were measured on the core with a mobile $\mathrm{X}$-ray fluorescence scanner (Analyticon, Xlt 700) at $2 \mathrm{~cm}$ intervals and the element ratios of $\mathrm{K} / \mathrm{Ca}$ and $\mathrm{Rb} / \mathrm{Sr}$ were calculated. Grain size, $\mathrm{CaCO}_{3}$, CNS and total organic carbon (TOC) were analyzed at sediment samples of $2 \mathrm{~cm}$, taken at $5 \mathrm{~cm}$ intervals.

For grain size analysis the samples were air-dried. To remove the organic matter the samples were treated with $0.3 \mathrm{ml} 30 \% \mathrm{H}_{2} \mathrm{O}_{2}$ at $70{ }^{\circ} \mathrm{C}$ for 24 hours. The carbonates were not removed in order to provide the possibility of also measuring agglomerated aeolian particles, which are cemented by carbonate (Kilibarda et al. 2008). For keeping the particles in dispersion the samples were treated with $0.25 \mathrm{ml} \mathrm{Na}{ }_{4} \mathrm{P}_{2} 0_{7}$ for 12 hours. The grain size measurement was done with a Laser Diffraction Particle Size Analyzer (Beckman Coulter LS 13 320) calculating the mean diameters of the particles within a size range of $0.04-2000 \mu \mathrm{m}$ and an error of $2 \%$. Each sample was measured nine times in order to exclude a deviation of the results. The grain size distribution (GSD), mean grain size and volume percentage of clay, silt and sand were calculated with the Beckman Coulter LS Software. The contents of carbon, nitrogen and sulphur were measured with a CNS analyzer (Eurovector EA3000) after air- 
drying and grinding of the samples. $\mathrm{CaCO}_{3}$ was determined volumetrically whereas the TOC was calculated as $\left(\mathrm{C}-\left(\mathrm{CaCO}_{3} * 0,12\right)\right) * 1.72$ (Scheffer and Schachtschabel 2002).

For palynological studies 56 sediment samples of $0.51 \mathrm{~cm}^{3}$ were taken from 700 to $200 \mathrm{~cm}$ at 5 to 10 $\mathrm{cm}$ intervals. The samples were treated with standard methods using $\mathrm{HCl}, \mathrm{KOH}, \mathrm{HF}$ and acetolysis (Erdtman 1960, Moore et al. 1999). The suspensions were sieved in an ultrasonic bath on a $1.5 \mu \mathrm{m}$ mesh and stored in glycerin. Lycopodium spores were added before $\mathrm{HCl}$ treatment as exotic markers to calculate the concentration and influx of pollen grains and burnt plant fragments (,charcoals“). Identification and nomenclature of pollen and spore types was relied on the reference collections of the department of Palynology and Climate Dynamics in Göttingen and relevant literature (Vánky 1994, Moore et al. 1999, van Geel et al. 2003, Beug 2004). In all except three samples the counted pollen sum was about 400 pollen grains excluding Cyperaceae and water plants. All values of pollen and spore taxa are related to this sum. The software $\mathrm{C} 2$ version 1.5.1 was used to illustrate the results (Juggins 2007). Around a quarter of the nearly 100 recorded pollen and spore taxa are presented in Fig.5. Small values are displayed by an additional exaggeration line (10x). The taxa are arranged according to their ecology and chronological appearance. Sub-samples for ostracod analysis were collected at $4 \mathrm{~cm}$ intervals, treated with $3 \% \mathrm{H}_{2} \mathrm{O}_{2}$ for 48 hours and washed through 0.25 and $0.1 \mathrm{~mm}$ meshes at the Institute of Geological Sciences at the Freie Universität Berlin. All ostracod shells were picked from the dried sieve residues and identified.

AMS radiocarbon dating was performed on eight samples which were measured by the AMS ${ }^{14} \mathrm{C}$ laboratory in Erlangen (Germany) and the Poznań Radiocarbon Laboratory (Poland). The calendric age-conversion of the resulting radiocarbon ages was performed with the online version of the program CalPal using the calibration curve CalPal2007-HULU (Weninger and Jöris 2008).

\section{Results}

\subsection{Chronology}

Eight AMS ${ }^{14} \mathrm{C}$ datings were performed on bulk material due to missing terrestrial plant remains. A first set of four samples processed at the AMS-Laboratory of Erlangen University (Erl.) revealed a time inversion in $353 \mathrm{~cm}$ (Tab.3.1). A control set of another four samples adjacent to the samples measured in Erlangen was analyzed in the Poznan Radiocarbon Laboratory (Poz.) which confirmed the previous results. The sample at a depth of $367 \mathrm{~cm}$ was measured twice in order to verify the results (Tab. 3.1).

In order to frame an acceptable age-depth model several possible influences on the measured ages are to assess. One factor obscuring the real age of a given sample is the reservoir effect caused by old carbon being incorporated by photosynthetic active water plants. As reported from central Asia this can lead to an age overestimation of a few hundred to about 2000 years (Rickettsa et al. 2001, Feng et al. 2005, Guo et al. 2007). In the catchment area of the Bayan Tohomiin Nuur carbonate rocks as 


\begin{tabular}{|c|c|c|c|c|c|}
\hline Depth [cm] & Lab. No & $\begin{array}{c}{ }^{14} \mathrm{C} \text { age and } \\
\text { error [yr. BP] }\end{array}$ & $\delta^{13} \mathrm{C}[\%$ ] $]$ & $\begin{array}{c}\text { calibrated } \\
\text { age and SD } \\
\text { [cal. yr. BP] }\end{array}$ & material \\
\hline 247 & Poz-37868 & $5495 \pm 35$ & $-21,3$ & $6299 \pm 24$ & bulk sample \\
\hline 253 & Erl-13181 & $5880 \pm 46$ & -20.5 & $6709 \pm 45$ & bulk sample \\
\hline 353 & Erl-12109 & $8697 \pm 56$ & -22.7 & $9674 \pm 85$ & bulk sample \\
\hline 367 & Poz-37949 & $9270 \pm 50$ & $-25,1$ & $10441 \pm 88$ & bulk sample \\
\hline 367 & Poz-37869 & $9320 \pm 60$ & $-24,6$ & $10523 \pm 90$ & bulk sample \\
\hline 526 & Erl-13182 & $6037 \pm 47$ & -21.6 & $6884 \pm 64$ & bulk sample \\
\hline 536 & Poz-37870 & $6920 \pm 40$ & $-26,8$ & $7222 \pm 36$ & bulk sample \\
\hline 674 & Erl-12110 & $10661 \pm 56$ & -23.3 & $12661 \pm 65$ & bulk sample \\
\hline 665 & Poz-37871 & $11170 \pm 70$ & $-27,4$ & $13073 \pm 125$ & bulk sample \\
\hline
\end{tabular}

Tab. 3.1: Results of the AMS ${ }^{14} \mathrm{C}$-datings and the calendric age-conversion (calibration) with $1 \sigma$ standard deviation (SD) using "CalPal-online" with calibration curve CalPal2007-HULU (Weninger and Jöris 2008).

source of old carbon are unknown. Moreover the Bayan Tohomiin Nuur as a flat and temporary desiccating lake should be in an isotopic equilibrium with the atmosphere by intense $\mathrm{CO}_{2}$ interchange. Therefore the age data should not be affected in this way. The low amounts of $\delta^{13} \mathrm{C}$ point to a predominantly terrestrial origin of the dated carbon, as remarkable contributions of water plants to the dated material could be identified by higher $\delta^{13} \mathrm{C}$ values (Stuiver and Polach 1977, Herzschuh et al. 2005). For that reasons all dating results seem to be more or less free of the reservoir effect.

A source of old carbon causing the observed age inversion could have been land snails, which occurred at about $360 \mathrm{~cm}$ depth. Redeposit 'charcoals' (Fig. 5 burnt plant fragments) can also be considered as a source of old carbon. Neglecting the ages of about $10 \mathrm{ka} \mathrm{cal} \mathrm{B.P.} \mathrm{around} 360 \mathrm{~cm}$ depth for any reasons, would result in a very high sedimentation rate of nearly $300 \mathrm{~cm}$ in less than 1000 years. That high sedimentation rate is missing any evidence in the sediment parameters including the suitable high pollen concentration.

As clear decisions are masked by the depicted and possibly other reasons, we considered to use the given dates without reservoir or other correction to build a tentative age-depth model. Assuming a relatively young retreat of the flat lake the surface was included with its recent age into the model. Because the time inversion expels a linear interpolation the age-depth model (Fig. 3.2) is based on a polynomial graph best fitting to the calibrated latest data set (Poz. 37868 - Poz. 37871). This age-depth model dates the profile base to around $15 \mathrm{ka}$ cal B.P. 


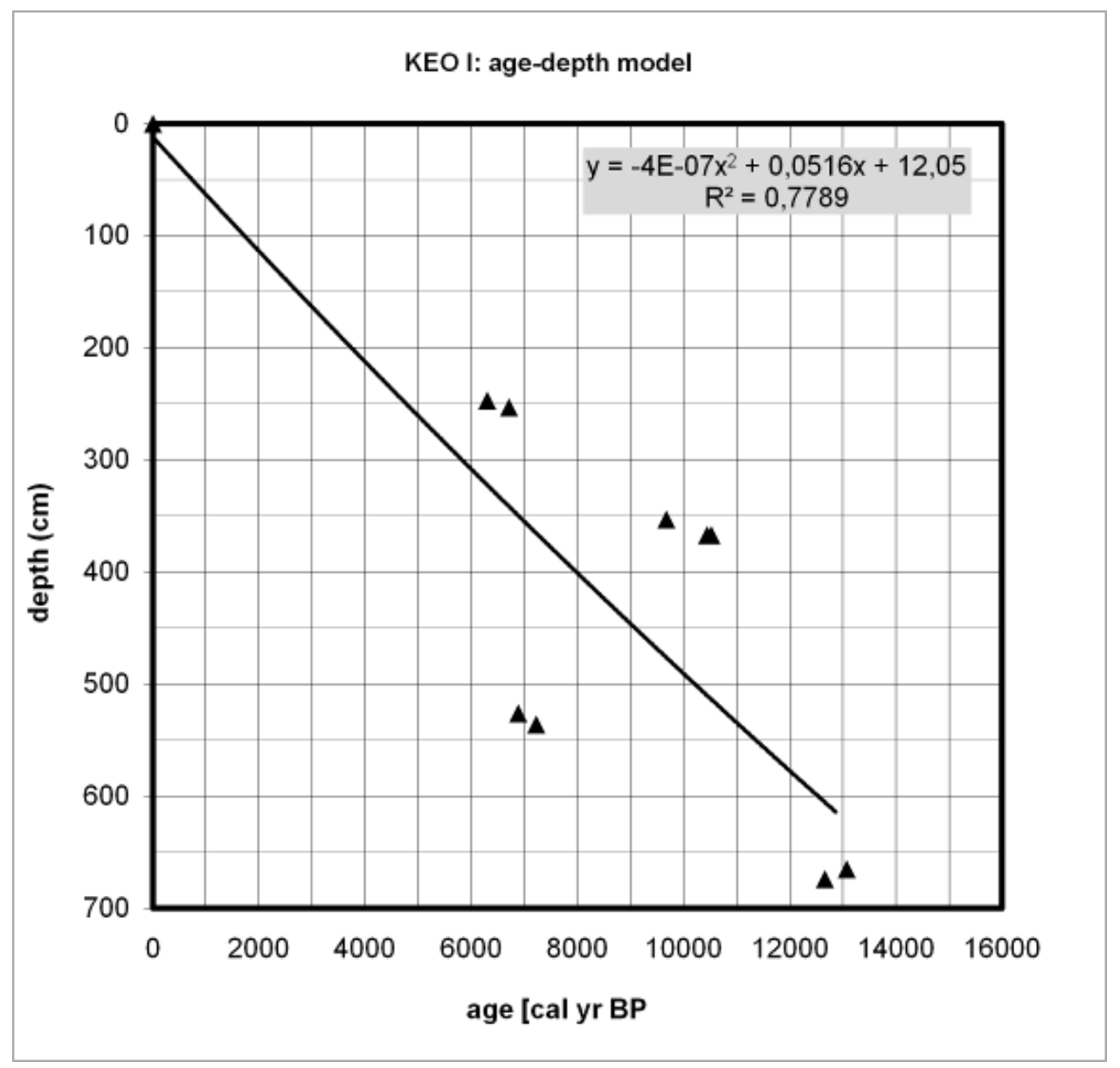

Fig. 3.2: Age-depth model of the core Bayan Tohomiin Nuur based on a polynomial graph best fitting to the calibrated latest data set (Poz. 37868 - Poz. 37871)

\subsection{Sediment analysis}

The sediment core is composed of lacustrine fine silt and clay, partly interbedded with layers of aeolian fine sand and coarse silt. Based on variations of the palynological and sedimentological data nine stratigraphic units from bottom to top were identified (I - IX) (Fig. 3.3). The sediments of units I IV (below $383 \mathrm{~cm}$ ) are black-coloured and show a faint lamination, whereas those of units V - IX (above $383 \mathrm{~cm}$ ) are grey-coloured and consist of homogeneous units with a weak horizontal bedding.

The grain size analysis of the sediment core yielded two different types of deposits. Most of the samples (75\%) feature means grain sizes between 6 and $14 \mu \mathrm{m}$. The grain size distribution (GSD) of these sediments shows a unimodal distribution (GSD1) with a peak at the fine sediment fraction (2-10 $\mu \mathrm{m}$ ) and a low sand content (Fig. 3.3). The second type of sediment occurs as peak value of the mean grain size $(>15 \mu \mathrm{m})$, caused by an increasing sand content. Grain size analyses of these sediments show the appearance of two peaks, one at the clay and silt fraction $(2-10 \mu \mathrm{m})$ and one at the sand fraction $(63-200 \mu \mathrm{m})$, resulting in a bimodal distribution (GSD2). 


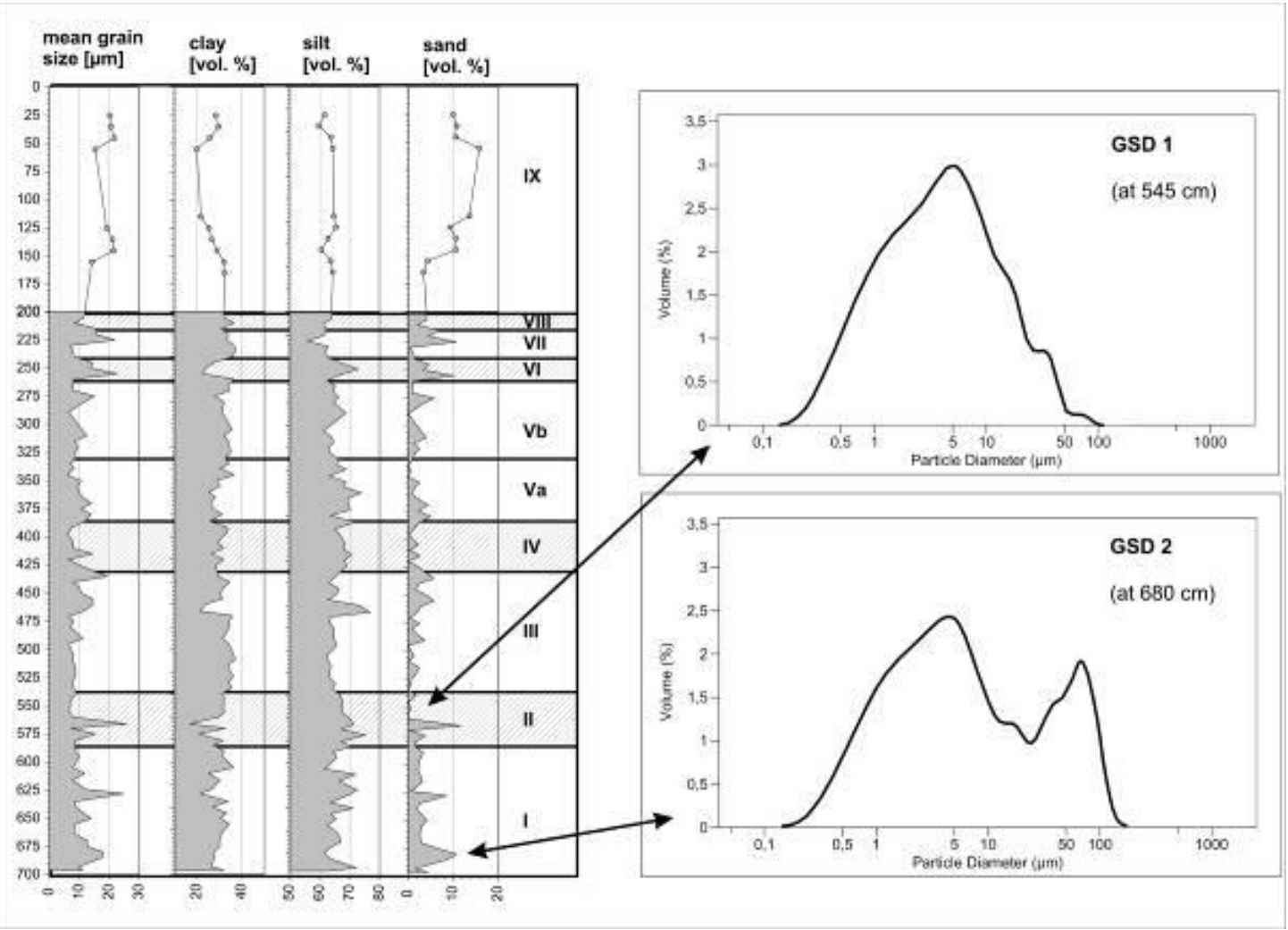

Fig. 3. 3: Results of the grain size analysis: The volume percent of the clay, silt and sand-sized fraction is displayed with the mean grain size. GSD 1 shows a representative grain size distribution with a peak at clay and silt sized particles (unimodal distribution). GSD 2 is composed of two peaks (bimodal distribution), one occurring at the clay and silt fraction the second at the sand fraction.

The element concentrations of $\mathrm{Ti}, \mathrm{Fe}, \mathrm{Mn}, \mathrm{K}$ and $\mathrm{Rb}$ show consistent trends with low values at units $\mathrm{I}$, III, Vb, VII (Ti: 2000-3000 ppm; Fe: 18000-20000 ppm) and increased values at units II, IV, Va and VI (Ti: 3000-4000 ppm; Fe: >20000 ppm) (Fig.4). This corresponds to $\mathrm{K} / \mathrm{Ca}$ and $\mathrm{Rb} / \mathrm{Sr}$ ratios which also show low values at units I, III, Vb, VII and high values at units II, IV, VI. $\mathrm{Sr}$, $\mathrm{Ca}$ and $\mathrm{CaCO}_{3}$ show an increasing trend from bottom to top $\left(\mathrm{CaCO}_{3}\right.$ unit I: $16 \%$, unit IX 20-40 \%) with higher values at units I, III and Vb and lower concentrations at II, IV and VI. Variations of $\mathrm{C}_{\text {total }}$, TOC, N and TOC/N are consistent to changes of $\mathrm{Sr}, \mathrm{Ca}$ and $\mathrm{CaCO}_{3}$, yielding lower amounts at unit II, IV and VI and higher concentrations at units I, III and $\mathrm{Vb}$ (Fig. 3.4). The concentration of sulphur shows high values from unit I to $\mathrm{V}$, being interrupted by lowered values at the beginning of unit III and the unit Va. The S content in the upper parts of the core (Units VI - IX) remains low. 


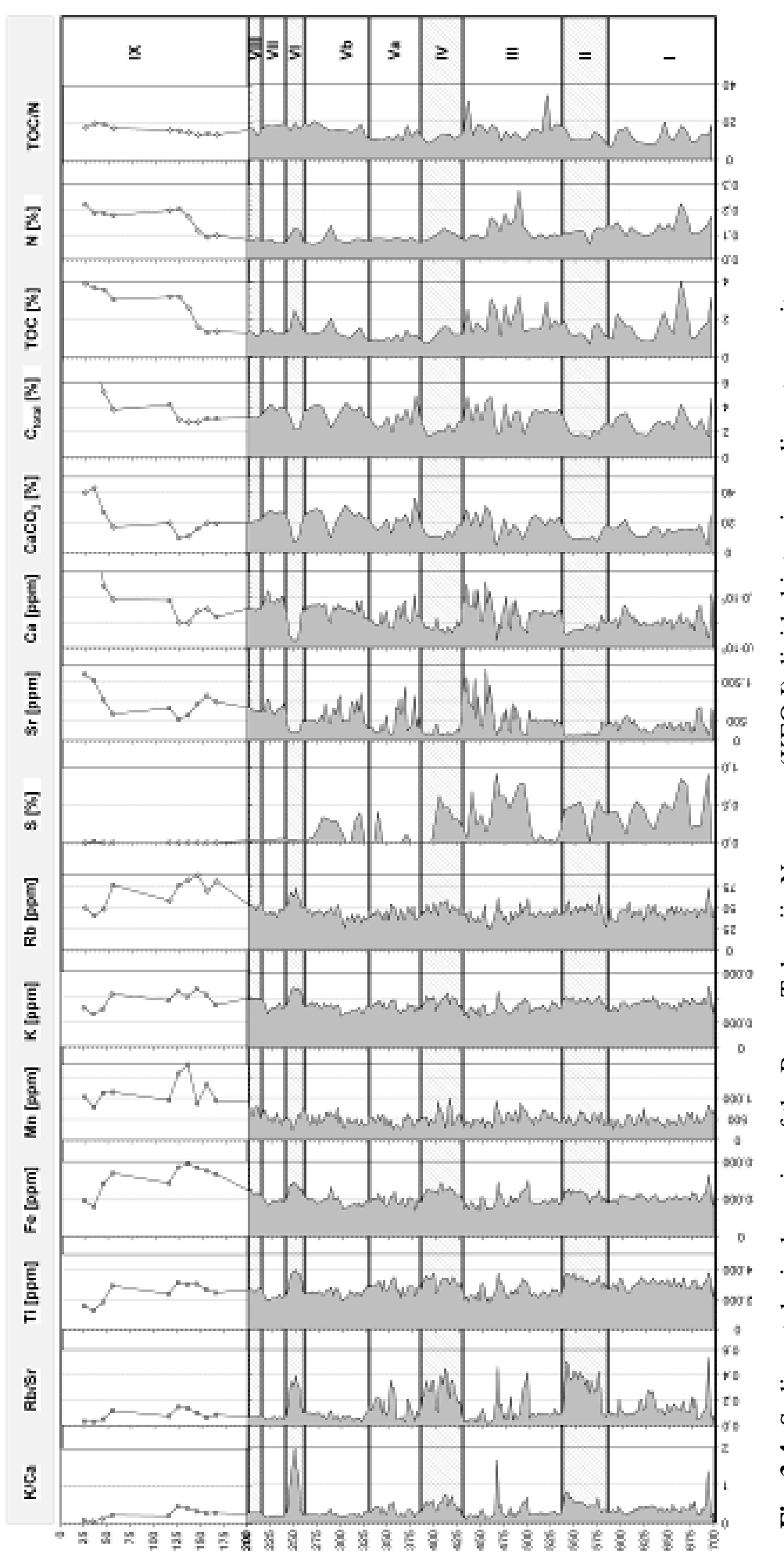

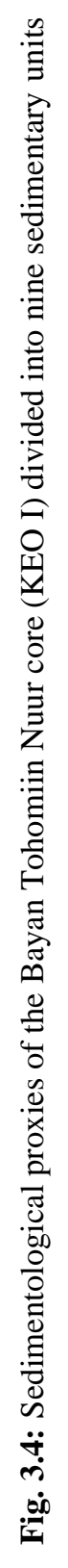




\subsection{Palynological and ostracod analysis}

Palynological analyses were restricted to the well preserved material of units 1 to VIII $(200-700 \mathrm{~cm})$. The pollen taxa Artemisia and Chenopodiaceae along with Ephedra are dominating throughout the whole diagram (Fig. 3.5). Artemisia and Chenopodiaceae exhibit opposite alternating low and high values of up to $70 \%$ and $58 \%$. Consequently, the Artemisia/Chenopodiaceae (A/C) ratio ranges from 0.2 to 5.5 , being low in the units II, IV, VI, VIII. Generally, phases with higher values of Chenopodiaceae (mean values: unit II/42\%, unit IV/38\%, unit VI/30\%, unit VIII/26\%) are accompanied by an increasing abundance of Ephedra (II/24\%, IV/36\%, VI/48\%, VIII/32 \%) and spores of Glomus (II/7\%, IV/6\%, VI/10\%, VIII/3\%). The aforementioned pollen and spore values of 0$0.75 \%$ in units VII and VIII are low. The ostracod data yield low concentrations of shells throughout the taxa show low abundances in the odd-numbered units I, III, V and VII, while mean values of Artemisia are high (I/45\%, III/48\%, V/57\%, VII/52\%). The mean values of Chenopodiaceae (I/24\%, $\mathrm{III} / 20 \%, \mathrm{~V} / 20 \%, \mathrm{VII} / 21 \%)$ and Ephedra (I/16\%, III/24\%, V/16\%, VII/23\%) are low and Glomus occurs with about $2 \%$ in those units. The Poaceae show a slight and gradual decrease from bottom to top with a maximum of $7.25 \%$ in unit I and core, although two sections with higher shell frequencies can be identified (Fig. 5).

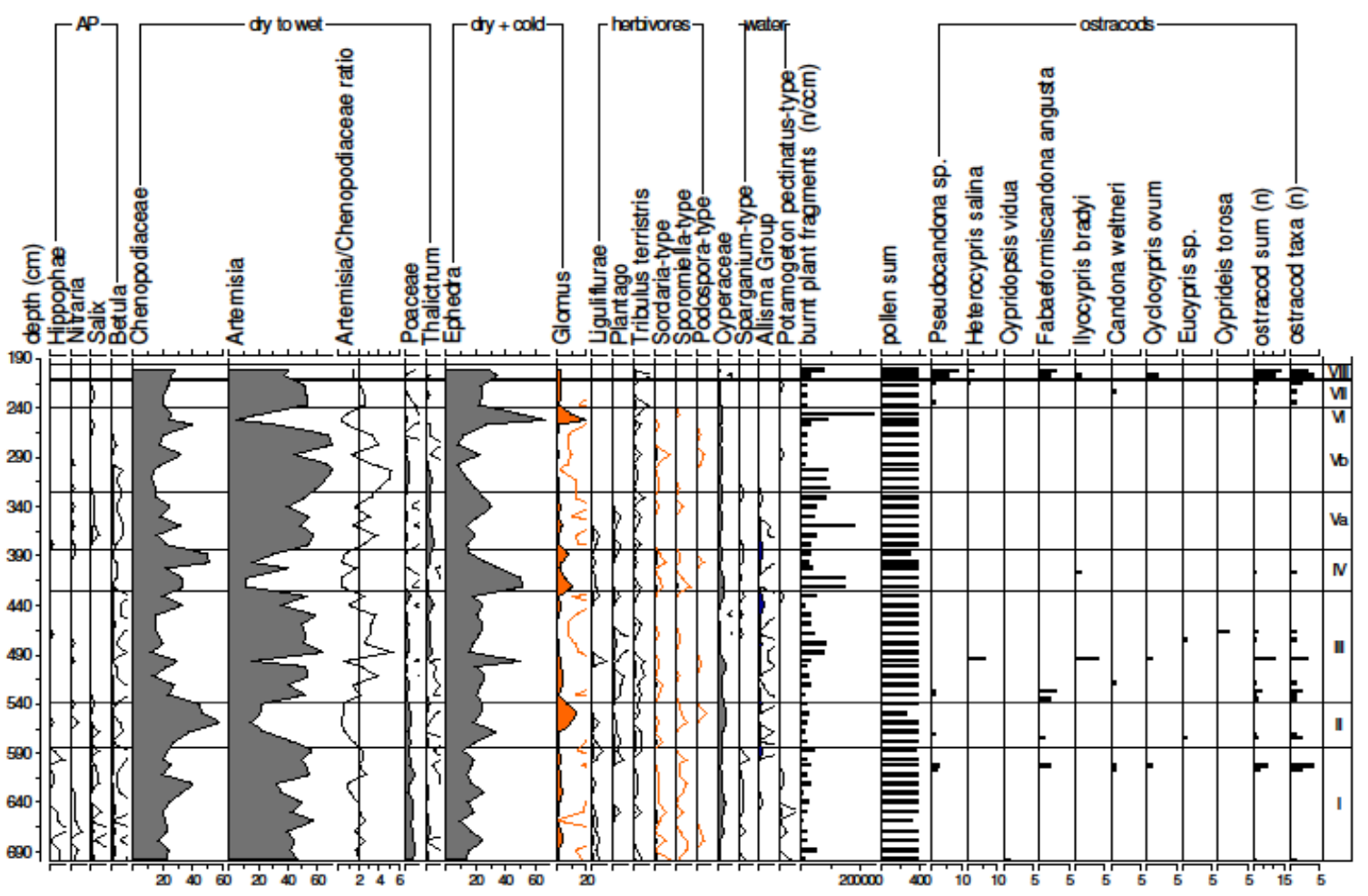

Fig. 3.5: Palynological proxies in percentages, ratio, concentration and absolute ostracod abundances. AP: arboreal pollen (shrubs and trees) 
Between 607 and $495 \mathrm{~cm}$ (upper unit I to lower unit III) shells of Candona weltneri, Fabaeformiscandona angusta, Cyclocypris ovum and Cyprideis torosa occur. The second section with a higher frequency of ostracod shells is found at 215-203 cm (unit VIII) and is characterized by shells of Heterocypris salina, Cyclocypris ovum, Fabaeformiscandona angusta, Ilyocypris bradyi and Candona weltneri.

\section{Discussion}

\subsection{Core interpretation}

The distinction between different mechanisms of sedimentation is helpful to receive information about past environmental and climatic conditions. Therefore, the multi-proxy analysis may provide information about vegetation changes, weathering and sedimentation processes, transport distance and source area. Due to the alteration between dry lake, shore vegetation and shallow lake the Bayan Tohomiin Nuur represents a sensitive archive for different sedimentation processes triggered by changing climatic conditions. The given ages are based on the age-depth model (chapter 4.1) in order to get an impression of the timing of the different processes although we were not able to establish a precise chronologyas we do not know if there is a possible reservoir effect.

\section{Late Glacial}

Unit I (700-585 cm; 15-12 ka cal BP): relatively wet and cold climate, Artemisia steppe

The lowermost unit consists of well stratified, black coloured sediments deposited in anoxic conditions. This is in consistence with a high concentration of $\mathrm{S}$, also pointing towards an anoxic milieu (Peck et al. 2002, Banks et al. 2004, Tomkins et al. 2005, Melles et al. 2007). Grain size analyses show the dominance of clay and silt-sized particles. The occurrence of largely unimodal GSD of the sediments $(675-630 \mathrm{~cm}, 620-585 \mathrm{~cm})$ is indicative of shallow lake sediments and fluvial sediments being deposited in distal environments (Prins et al. 2000). At 690-685 cm and 628-624 cm an increase of sand and coarse silt could be observed. GSD of these sediments show the appearance of a second peak at the 36-200 $\mu \mathrm{m}$ fraction, thus indicating a further transport and deposition process being responsible for the bimodal distribution. A fluvial origin of the second peak is thought to be unlikely because in this case the particle size distribution would show a unimodal and gradual trend (Prins et al. 2000). Therefore the coarse silt - fine sand peaks may represent aeolian input connected to the Khongory Els dune field, indicating short phases of dune activity (Hempelmann 2011). Low K/Ca and $\mathrm{Rb} / \mathrm{Sr}$ ratios and low values of $\mathrm{Ti}, \mathrm{Fe}, \mathrm{Mn}, \mathrm{K}$ and $\mathrm{Rb}$ in unit $\mathrm{I}$ are attributed to the lithogenous sediment fraction, indicating a marginal input of clastic sediments (Wünnemann et al. 1998, Fedotov et al. 2000, Mischke et al. 2003, Mischke et al. 2005, Jin et al. 2006, Schwanghardt et al. 2008). This points to towards stable and dry climatic conditions without significant slope wash, which is consistent with increasing values of $\mathrm{C}_{\text {total }}, \mathrm{N}$ and TOC (2-3\%) (Fig.4), indicating an increased productivity of the 
lake and a dense vegetation cover within the catchment area (Chen et al. 2003, Jin et al. 2006). TOC/N values around 15-20 show the dominance of autochthonous organic matter with only few input from the catchment of the lake (Horiuchi et al. 2000, Chen et al. 2003, Wang et al. 2004, Herzschuh et al. 2005, Jin et al. 2006, Guo et al. 2007). The occurrence of shells of Candona weltneri, Fabaeformiscandona angusta and Cyclocypris ovum points to freshwater or oligohaline conditions. The relatively low contents of $\mathrm{CaCO}_{3}(16-20 \%), \mathrm{Sr}$ and $\mathrm{Ca}$ are used as indicators of temperature and moisture (Guo et al. 2007). Accordingly, low contents of $\mathrm{CaCO}_{3}, \mathrm{Sr}$ and $\mathrm{Ca}$ point to a low rate of carbonate precipitation, caused either by a low water temperature or by large discharge to the lake and an extension of the lake volume. Therefore a low temperature and a less dry climate conditions can be assumed. At a depth of $695 \mathrm{~cm}$ a short period of enhanced slope wash is recorded by peaks of K/Ca, $\mathrm{Rb} / \mathrm{Sr}$, Ti, Fe, Mn, $\mathrm{K}$ and $\mathrm{Rb}$. Consistent low values of $\mathrm{C}_{\text {total }}$ and TOC (1.8\%) indicate a reduction of lake productivity and vegetation cover.

During unit I Artemisia occurs with about $45 \%$ and Chenopodiaceae with around 24\%. Accordingly, the Artemisia/Chenopodiaceae ratio (A/C ratio) yields moderate values around 2, indicating neither very dry nor very moist growing conditions in the area (Fig. 5). The landscape was probably covered by an Artemisia steppe with shrubs of Ephedra, growing on a rocky or gravelly surface. Shrubs or small trees of Hippophä̈ may have grown along the streams and Nitraria shrubs at sandy sites with efflorescent salts. Beside climate and soil properties, the vegetation biodiversity was also affected by grazing animals and fires as indicated by burnt plant fragments. The herbivores are indicated by pollen of grazing weeds (Liguliflorae, Tribulus terrestris and Plantago) as well as by spores of coprophilous ascomycetes (Sordaria-, Sporormiella- and Podospora-type) living on their dung. Pollen grains of Potamogeton pectinatus-type, Sparganium-type and relative high Poaceae values denote to a vegetation zonation at the lake shore with submersed plants in shallow waters and reed beds similar to Lake Orog Nuur at present (Hilbig 1995).

\section{Unit II (585-538 cm; 12-11 ka cal BP): dry and cold climate, Chenopodiaceae desert}

The dominance of black laminated lacustrine clay and high contents of S suggest a continuing anoxic lake-bottom environment. The sediments largely consist of clay and silt (approx. 95\%), therefore indicating lacustrine or distal fluvial deposition as the main process (Prins et al. 2000). At $565 \mathrm{~cm}$ a short phase of aeolian deposition can be derived from an increasing sand content (> 12\%) and a bimodal GSD pattern. An increased input of clastic sediments is inferred from high $\mathrm{Rb} / \mathrm{Sr}$ and $\mathrm{K} / \mathrm{Ca}$ ratios and increased contents of $\mathrm{Ti}, \mathrm{Fe}, \mathrm{Mn}, \mathrm{K}$ and $\mathrm{Rb}$. Furthermore, reduced values of TOC (1.0$1.5 \%), \mathrm{N}$ and $\mathrm{C}_{\text {total }}$ indicate a declining lake productivity and a reduction of soil and vegetation cover within the catchment area (Fig.4). Low TOC/N values also indicate a lower input of allochthonous organic matter. While low $\mathrm{Ca}, \mathrm{Sr}$ and $\mathrm{CaCO}_{3}$ (7-10\%) contents indicate the prevalence of cold conditions, increased sediment input and reduced lake productivity as well as the occurrence of aeolian sand probably result from an increased aridity. 
The low A/C ratio and high Ephedra values point to a Chenopodiaceae desert under very dry conditions with extensive barren ground, dotted with Ephedra shrubs growing in rock cleavages caused by physical weathering (Schlütz and Lehmkuhl 2007). Due to the low vegetation cover probably accompanied by uneven casual torrential rain falls, the soil erosion and input of minerogenic material into the lake increased consequently, which is indicated by the high values of spores of the mycorrhizal fungi (Glomus-type). The absence of water-plant pollen (Potamogeton pectinatus-, Sparganium-type) points to a shrunken or even temporarily desiccated lake.

\section{Late Pleistocene to Holocene}

\section{Unit III (538-430 cm; 11-8.5 ka cal BP): more wet and instable climate, Artemisia steppe}

Sediments of unit III show prevailing anoxic lake-bottom conditions (black colour, lamination, high S content). The deposits of the lower part $(538-460 \mathrm{~cm})$ consist of lacustrine clay and silt, whereas a rising amount of sand (up to $8 \%$ ) occurs between $460 \mathrm{~cm}$ and $435 \mathrm{~cm}$ (Fig.3). This points towards a further period of aeolian sediment input. Rising amounts of TOC (2-3\%), N and $\mathrm{C}_{\text {total }}$ indicate an increased vegetation cover and probably soil formation within the lake catchment. The contribution of allochthoneous organic matter in this period is indicated by a raised TOC/N ratio (30-40). Low $\mathrm{Rb} / \mathrm{Sr}$ and $\mathrm{K} / \mathrm{Ca}$ ratios and low $\mathrm{Ti}, \mathrm{Fe}, \mathrm{Mn}, \mathrm{K}$ and $\mathrm{Rb}$ values result from a reduced input of clastic sediments. Therefore a more humid environment with increased vegetation cover and a reduced fluvial sediment transport can be assumed. The rising aeolian sedimentation indicates a strengthening of wind speed during this period. Increased contents of $\mathrm{CaCO}_{3}$ (16-28\%), $\mathrm{Ca}$ and $\mathrm{Sr}$ point to a higher rate of carbonate precipitation probably in conjunction with a higher temperature (Guo et al. 2007). The occurrence of Fabaeformiscandona angusta, Ilyocypris bradyi and Candona weltneri points towards freshwater or oligohaline conditions of the lake whilst the low shell number and sporadic pattern reflects the predominance of anoxic conditions at the lake bottom. The record of Cyprideis torosa shells at $467 \mathrm{~cm}$ core depth indicates more saline conditions of a permanent lake. Variations of the vegetation and clastic sediment proxies between $500 \mathrm{~cm}$ and $460 \mathrm{~cm}$ hint to unstable conditions and short-term fluctuations towards a dryer environment.

The sharp reversal to Artemisia dominated pollen spectra and A/C ratios higher than 2 document significantly wetter climatic conditions during unit III. The increases in Thalictrum pollen may indicate even the establishment of some meadow-steppe like vegetation and underline the higher effective moisture (Hilbig 1995, Grubov 2001).

\section{Unit IV (430-383 cm; 8.5-7.5 ka cal BP): dry and cold climate, Chenopodiaceae desert}

Black coloured and laminated lacustrine clay indicates prevailing anoxic bottom conditions of the lake. Thus decreasing concentrations of S point towards a rising oxygen content which is also an indicator of a lower lake level (Peck et al. 2002, Melles et al. 2007). The grain size data shows the dominance of clay and silt sized particles, while the amount of sand remains low (2-3\%) (Fig. 3), thus indicating a 
reduced aeolian input. High $\mathrm{Rb} / \mathrm{Sr}$ and $\mathrm{K} / \mathrm{Ca}$ ratios and high amounts of $\mathrm{Ti}, \mathrm{Fe}, \mathrm{Mn}, \mathrm{K}$ and $\mathrm{Rb}$ point towards an increased input of clastic sediments which refers to dry conditions. Low values of $\mathrm{C}_{\text {total }}$, TOC (0.8-1.5\%) and $\mathrm{N}$ indicate a reduction of lake productivity and vegetation cover. Low TOC/N values around 10 document a mainly autochthonous source of TOC, which is consistent with a reduced vegetation cover of the catchment. Low contents of $\mathrm{CaCO}_{3}(10-12 \%), \mathrm{Ca}$ and $\mathrm{Sr}$ hint towards a reduced carbonate precipitation, probably indicating a decline of the water temperature.

Low A/C ratios indicate the dominance of dry climatic conditions during unit IV, while raised Ephedra values are indicative of a cold environment. The occurrence of burnt plant fragments and a high content of Glomus-type spores points to an increased input of eroded soil material.

\section{Unit V (383-260 cm; 7.5-5 ka cal BP): most wet and warm climate, Artemisia steppe}

Due to gradual changes in geochemistry and palynology unit $\mathrm{V}$ is divided into two subunits $\mathrm{Va}$ and $\mathrm{Vb}$. The lower subunit $\mathrm{Va}$ is characterized by black coloured and laminated lacustrine sediments composed of clay and silt. A change of sediment structure and colour towards grey weakly stratified clay occurs at $325 \mathrm{~cm}$ (subunit $\mathrm{Vb}$ ) and was probably caused by a decline of the lake level, thus facilitating processes of oxidation and turbation (Peck et al. 2002). The GSD of the samples show unimodal distributions with high contents of clay (30-40\%) and silt (60-70\%), while the amount of sand remains low (<5\%) (Fig.3). This refers to a dominance of lacustrine sedimentation processes during unit $\mathrm{V}$, while the aeolian contribution is low. In subunit Va low concentrations of $\mathrm{C}_{\text {total }}, \mathrm{TOC}$ (1 $\%)$ and $\mathrm{N}$ indicate a low lake productivity. A change towards higher amounts of $\mathrm{C}_{\text {total }}$, TOC (1-2\%) and $\mathrm{N}$ in subunit $\mathrm{Vb}$ (Fig. 4) can be connected to an increasing productivity of the lake and an increase of the vegetation cover. The elements $\mathrm{Ti}, \mathrm{Fe}, \mathrm{Mn}, \mathrm{K}$ and $\mathrm{Rb}$ yield low concentrations in subunits $\mathrm{Va}$ and $\mathrm{Vb}$, while $\mathrm{Rb} / \mathrm{Sr}$ and $\mathrm{K} / \mathrm{Ca}$ show a decreasing trend from $\mathrm{Va}$ to $\mathrm{Vb}$ (Fig.4). This supports the assumption of an increasing lake productivity and vegetation cover, thus reducing the surface runoff and the input of clastic sediments (Wünnemann et al. 1998, Fedotov et al. 2000, Mischke et al. 2003, Mischke et al. 2005, Jin et al. 2006, Schwanghardt et al. 2008). The content of $\mathrm{CaCO}_{3}$ shows variable concentrations in subunit Va ranging between $10 \%$ and $25 \%$. Concentrations of $\mathrm{Ca}$ and $\mathrm{Sr}$ are similarly variable. This indicates changes in carbonate precipitation. At $\mathrm{Vb}$ high concentrations of $\mathrm{CaCO}_{3}(20-30$ $\%), \mathrm{Ca}$ and Sr probably imply a higher water temperature.

During subunit Va (383-325 cm; 7.5-6.5 ka cal BP) the precipitation increased (high Artemisia values) and relatively high Thalictrum values indicate the establishment of meadow-steppes () with Ephedra values suggesting relatively cool conditions. In subunit $\mathrm{Vb}(325-260 \mathrm{~cm}$; $6.5-5 \mathrm{ka}$ cal $\mathrm{BP})$ the increase of moisture continued, leading to $\mathrm{A} / \mathrm{C}$ ratios of more than 5 and to the highest Artemisia values of the whole pollen record (up to 70\%). Additionally low values of Ephedra and Glomus indicate a closed vegetation cover inhibiting erosion. Thus unit $\mathrm{V}$ represents a climatic moisture optimum that probably reflects the increase of the summer monsoon as reported by Schettler et al. (2006). 


\section{Unit VI (260-240 cm; 5-4.5 ka cal BP): dry and cold climate, Chenopodiaceae desert}

A strong oscillation of most proxies during this unit indicates a significant change of the environmental conditions which lasted only for a short period. A peak of $\mathrm{K} / \mathrm{Ca}, \mathrm{Rb} / \mathrm{Sr}, \mathrm{Ti}, \mathrm{Fe}, \mathrm{Mn}, \mathrm{K}$ and $\mathrm{Rb}$ indicates an increase of clastic sediment input connected to surface processes. This is corresponding to the deposition of dark brown coloured sediments with increased TOC (>2\%) and N contents, indicating a period of soil erosion during dry climatic conditions. Low contents of $\mathrm{C}_{\text {total }}, \mathrm{CaCO}_{3}(10 \%), \mathrm{Ca}$ and $\mathrm{Sr}$ probably suggest a low water temperature and a low lake productivity. The occurrence of aeolian sand and silt (silt: $75 \%$, sand: $10 \%$ ) at $255 \mathrm{~cm}$ points towards another activation phase of the nearby dune field.

The Artemisia curve reaches its minimum level in unit VI while values of Ephedra and Glomus and the abundance of burnt plant fragments are the highest of the whole diagram, reflecting an extremely dry and cold climatic reversal. The growing conditions were apparently even harsher than at the end of the late Glacial (unit II). Under the dry climate the sparse vegetation was effected by fires. The extreme high influx of burnt plant fragments and the high concentration of pollen grains may be seen as the result of an undammed surface runoff (Hartmann and Wünnemann 2009).

\section{Unit VII (240-212 cm; 4.5-4 ka cal BP): wet and warm conditions, Artemisia steppe}

The core sediments between 240 and $212 \mathrm{~cm}$ consist of grey, weakly stratified clay, deposited in a shallow lake environment. Increasing contents of $\mathrm{C}_{\text {total }}$, TOC (1-1.5\%), N, $\mathrm{CaCO}_{3}(20-30 \%)$, and $\mathrm{Ca}$ and $\mathrm{Sr}$ are similar to unit $\mathrm{V}$ probably indicating a higher water temperature, a higher lake productivity and a relatively dense vegetation cover within the catchment. This is consistent with high TOC/N ratios indicating a larger incorporation of allochthonous material into lake sediments. Low values of $\mathrm{K} / \mathrm{Ca}, \mathrm{Rb} / \mathrm{Sr}, \mathrm{Ti}, \mathrm{Fe}, \mathrm{Mn}, \mathrm{K}$ and $\mathrm{Rb}$ indicate wetter conditions with a reduced accumulation of clastic sediments. At $225 \mathrm{~cm}$ increased amounts of sand (> 10\%) hint to a further spell of dune activity.

During unit VII the A/C ratio rises to values slightly above 2 with Ephedra having moderate values, indicating wetter conditions. The absence of spores of coprophilous ascomycetes (Sordaria-, Sporormiella-and Podospora-type) may point to decreased influx of grazing herbivores.

\section{Unit VIII (212-195 cm; 4-3.5 ka cal BP): dry and cold conditions, Chenopodiaceae desert}

The sediments of this unit consist of grey, weakly stratified clay and silt. The occurrence of shells of Heterocypris salina and Cyclocypris ovum also hint towards a shallow lake environment, whereas Fabaeformiscandona angusta, Ilyocypris bradyi and Candona weltneri indicate more or less freshwater conditions. Therefore, the existence of a permanent shallow lake during this period is inferred. The sand content is low (2-3\%) and the unimodal GSD pattern is prevailing (Fig. 3), representing a low aeolian input. Increased concentrations of $\mathrm{Ti}, \mathrm{Fe}, \mathrm{Mn}, \mathrm{K}$ and $\mathrm{Rb}$ indicate a strengthening of surface runoff caused by a reduced vegetation cover. This is consistent with lower amounts of $\mathrm{C}_{\text {total }}$, TOC and N, suggesting dry climatic conditions. Reduced contents of $\mathrm{CaCO}_{3}(20 \%)$, 
and $\mathrm{Ca}$ and $\mathrm{Sr}$ are related to a lower carbonate precipitation, probably indicating a lower water temperature (Fig.4).

At the turn to unit VIII the $\mathrm{A} / \mathrm{C}$ ratio declines below 2 while Ephedra and burnt plant fragments become more frequent, indicating the beginning change to a dryer and colder climate again.

Unit IX (200-0 cm; 3.5-0 ka cal BP): dry and warm climate, desiccation of the lake, increasing dune activity

The upper $200 \mathrm{~cm}$ of the core cannot be divided into units because of the fragmentary sediment recovery and missing palynological data. However, some general features can be discussed. Grey, weakly stratified clay with a high amount of sand and silt can be observed throughout. GSD of the sediments show bimodal distributions, indicating an increasing accumulation of aeolian material. This points towards a desiccation of the lake, accompanied by the formation of the dune belt which persisted until present. Between $160 \mathrm{~cm}$ and $110 \mathrm{~cm}$ a change towards dry conditions can be inferred from increasing $\mathrm{K} / \mathrm{Ca}, \mathrm{Rb} / \mathrm{Sr}, \mathrm{Ti}, \mathrm{Fe}, \mathrm{Mn}, \mathrm{K}$ and $\mathrm{Rb}$ values, indicating an enhanced input of clastic sediments. A simultaneous decrease of $\mathrm{CaCO}_{3}(10-20 \%)$, and $\mathrm{Ca}$ and $\mathrm{Sr}$ indicates a reduction of the lake productivity, which can be caused by a shrinking of the lake. Peak values of TOC (3.7\%), N and $\mathrm{C}$ in this part of the core $(130-20 \mathrm{~cm})$ are probably caused by soil formation and vegetation cover within the transition zone between salt meadows and dune belt. This is also reflected by high TOC/N values. High amounts of $\mathrm{CaCO}_{3}(42 \%)$, and $\mathrm{Ca}$ and $\mathrm{Sr}$ at the top of the core indicate the formation of evaporites near the dune belt. This hints towards dry climatic conditions which were similar to the present situation. Low amounts of $\mathrm{K} / \mathrm{Ca}, \mathrm{Rb} / \mathrm{Sr}, \mathrm{Ti}, \mathrm{Fe}, \mathrm{Mn}, \mathrm{K}$ and $\mathrm{Rb}$ indicate a low clastic sediment input, which is not consistent with the dry environment. We assume that the clastic sediment input during this dry period is blocked by the dune belt.

\subsection{Paleoclimatic implications}

The geochemical, palynological and granulometric properties of the sediments from Bayan Tohomiin Nuur revealed several short-term changes during the transition from late Glacial to middle Holocene. These changes in sedimentation processes, input of pollen and accumulation of aeolian material reflect different climatic and environmental stages (Tab. 3.2).

For the first documented part of late Glacial cool and wet conditions could be affiliated within the catchment area (unit I: 15 - $12 \mathrm{ka}$ cal BP). This is consistent with high lake levels of Uvs Nuur (Walther 1999) and other lakes in northern Mongolia (Komatsu et al. 2001) as well as increased vegetation productivity at Bayan Nuur (Krengel 2000). In northern Mongolia higher lake levels are coupled to a retreat of the glaciers and an increase of the river discharge connected to the high mountain areas. An input of melt water can be excluded here as the catchment of the Bayan Tohoomin Nuur lacks any significantly elevated areas. We therefore assume that the lake level could be influenced by permafrost, thus reducing the infiltration within the basin and providing a supply of 
water from the slopes. The decreasing $\mathrm{S}$ content within the core reflects the change from anoxic towards oxic conditions, which can be connected to a degradation of the permafrost (increased exchange of oxygen witin the sediments after melting of the ice). This degradation of permafrost at the transition from Pleistocene to Holocene was also reconstructed for this region by Owen et al. (1998). Sediment unit II is characterized by a short phase of dry and cold conditions, lasting from $12-11 \mathrm{ka}$ cal BP. This change from more wet conditions between $15-12 \mathrm{ka}$ cal BP towards a dryer environment may represent the high continental equivalent to the change from the late glacial interstadials towards the Younger Dryas (Litt and Stebich 1999, Herzschuh 2006, Stebich et al. 2009).

The transition from unit II to unit III around $11 \mathrm{ka}$ cal BP is characterized by a rise of temperature and humidity, reflecting the climatic amelioration at the turn from the Pleistocene to the Holocene. This is in agreement with high lake levels and humid conditions at Uvs Nuur during the onset of the Holocene (Grunert et al. 2000). In northwestern China an increase of temperature and moisture was also reported by Pachur et al. (1995), Wang et al. (2004), Mischke et al. (2005) and Chen et al. (2006). This points to a strengthening of the Summer Monsoon and the westerlies as well leading to higher effective moisture in most parts of northern Asia (Komatsu et al. 2001, Morrill et al. 2003, Walther et al. 2003, Herzschuh 2006, Andreev and Tarasov 2007).

A change from wet/cool to dry/cold conditions at around $8.5 \mathrm{ka}$ cal BP (unit III/IV) marks a short climatic reversal in the early Holocene belonging to a sequence of alternating long and wet and short and dry phases appearing until $3.5 \mathrm{ka}$ cal BP. Several lake records from NW China and Mongolia indicate moist and warm conditions between about 7 - 5 ka cal BP (Walther et al. 2003, Wünnemann et al. 2003, Jiang et al. 2007). The dry/cold conditions during unit VI (5 - $4.5 \mathrm{ka}$ cal BP) are in agreement with the single mid-Holocene regression of lake Boston $\mathrm{Hu}$ (NW-China) dated to $5.5 \mathrm{ka}$ cal BP indicating a weakening of the westerlies (Wünnemann et al. 2003). The palaeoclimatic records from northern China and Mongolia show large inconsistencies in the timing of moisture supply and the change of temperatures. This can be interpreted as strong spatial climatic variability in this area due to the combined influence of the west wind system and the Asian monsoon (Mischke et al. 2005, Schettler et al. 2006, Jiang et al. 2007). Additionally the records are controlled by different further factors like rivers and glaciers, thus creating complicated mixed signals. The fractional data of the upper sediment sequence (unit IX), comprising the middle and late Holocene (since $3.5 \mathrm{cal} \mathrm{ka} \mathrm{BP}$ ), indicate a clear trend towards lake desiccation and a strengthening of the aeolian activity. This trend is corresponding to the aridization of southern Mongolia and adjacent areas of China during the late Holocene (Chen et al. 2003, Jiang et al. 2003, Walther et al. 2003, Wünnemann et al. 2003, Peng et al. 2005). Due to an increasing influence of pastoralism in Central Asia since the middle Holocene also a human impact on dune (re-)activation and landscape degradation has to be considered (Lehmkuhl et al. 2000, Schlütz 2000, Schlütz and Lehmkuhl 2009). 


\begin{tabular}{|c|c|c|c|c|c|c|c|c|c|c|}
\hline$\frac{5}{5}$ & $\underline{x}$ & $\overline{\bar{\Sigma}}$ & $\bar{\Sigma}$ & 5 & $>$ & $>$ & $\geq$ & $\equiv$ & $=$ & - \\
\hline 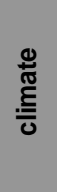 & 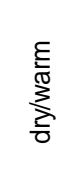 & 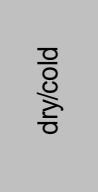 & $\begin{array}{l}\overline{0} \\
\overline{0} \\
\overline{0} \\
3\end{array}$ & 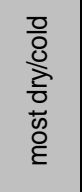 & 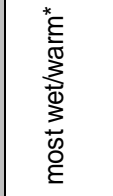 & 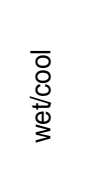 & 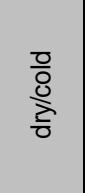 & 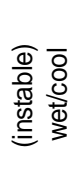 & $\begin{array}{l}\text { 응 } \\
\text { 중 } \\
\text { 잉 }\end{array}$ & $\begin{array}{l}\overline{0} \\
\overline{0} \\
\overline{0} \\
3\end{array}$ \\
\hline 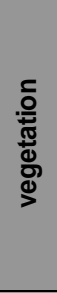 & 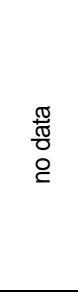 & 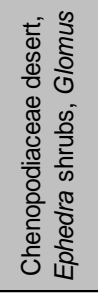 & 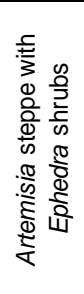 & 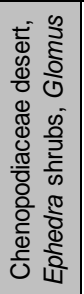 & 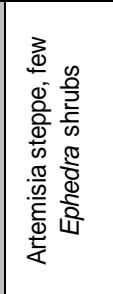 & 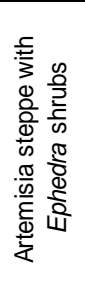 & 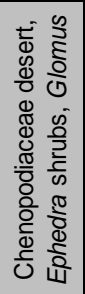 & 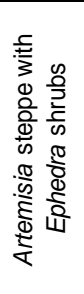 & 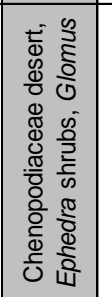 & 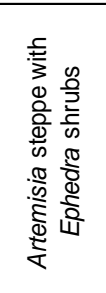 \\
\hline 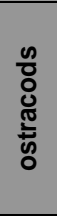 & $\begin{array}{l}\frac{\sqrt{5}}{\frac{\pi}{0}} \\
\text { O }\end{array}$ & 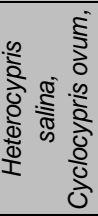 & $\begin{array}{l}\frac{\pi}{\pi} \\
\frac{\pi}{00} \\
\frac{0}{9}\end{array}$ & $\begin{array}{l}\frac{\pi}{\pi} \\
\frac{\pi}{00} \\
0\end{array}$ & $\begin{array}{l}\frac{\pi}{5} \\
\frac{\pi}{0} \\
0\end{array}$ & & $\begin{array}{l}\frac{\pi}{\frac{\pi}{50}} \\
\text { ㅇ }\end{array}$ & $\begin{array}{l}\frac{\pi}{\pi} \\
\frac{\pi}{50} \\
\text { O }\end{array}$ & 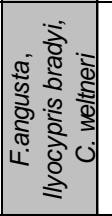 & 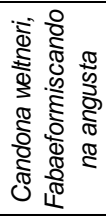 \\
\hline 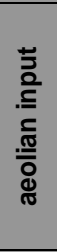 & 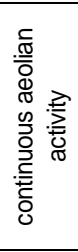 & 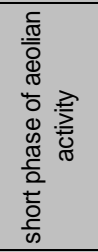 & 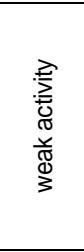 & 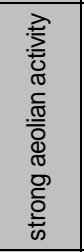 & 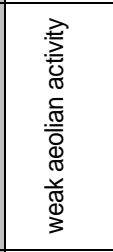 & 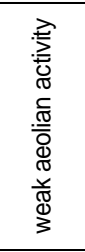 & 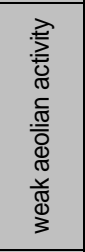 & 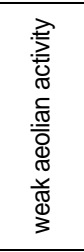 & 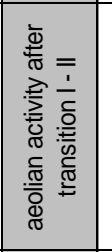 & 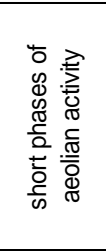 \\
\hline 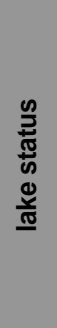 & 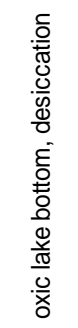 & 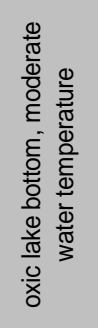 & 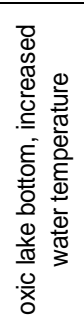 & 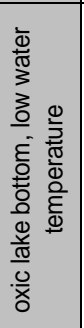 & 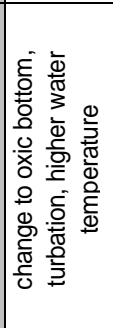 & 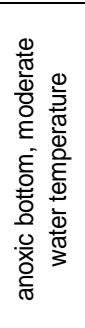 & 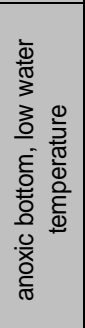 & 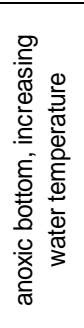 & 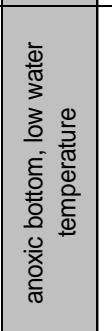 & 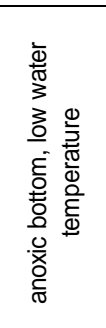 \\
\hline 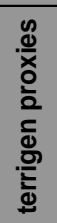 & 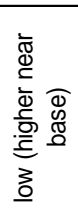 & 들 & $\underline{\underline{z}}$ & 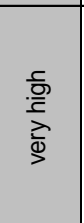 & $\underline{z}$ & $\begin{array}{l}\frac{\Phi}{\frac{\pi}{\pi}} \\
\frac{\pi}{0} \\
\frac{0}{\varepsilon}\end{array}$ & 들 & $\underline{z}$ & 들 & $\underline{\underline{z}}$ \\
\hline 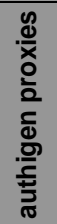 & 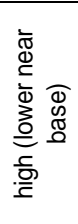 & zo & 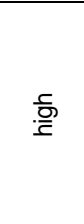 & $\frac{3}{\frac{3}{2}}$ & 들 & $\underline{\underline{z}}$ & zo & ․్ㅀ & zo & 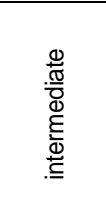 \\
\hline 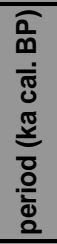 & 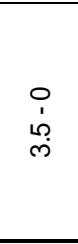 & 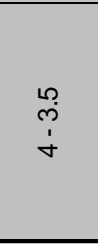 & 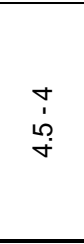 & $\begin{array}{l}\text { مُ } \\
\text { í }\end{array}$ & 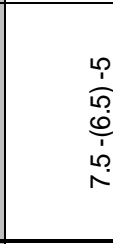 & & 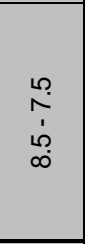 & $\begin{array}{l}\llcorner \\
\infty \\
1 \\
1 \\
\leftarrow\end{array}$ & $\begin{array}{l}\bar{\perp} \\
\stackrel{\check{N}}{\simeq}\end{array}$ & $\begin{array}{l}\frac{N}{1} \\
\stackrel{b}{n}\end{array}$ \\
\hline 奇 & $\underline{x}$ & $\overline{\bar{\Sigma}}$ & $\overline{\bar{\Sigma}}$ & 5 & $>$ & $\sum^{\pi}$ & $\geq$ & $\equiv$ & $=$ & - \\
\hline
\end{tabular}




\section{Conclusion}

The multiproxy study of the Bayan Tohomiin Nuur, comprising sedimentological, palynological and ostracod parameters, represents the first high resolution lake archive from southern Mongolia, revealing a high consistence of the different palaeoclimatic data. Our trans-disciplinary approach elucidated nine phases of landscape development and climate dynamics during the late Glacial and the Holocene. A change from wet/cool to dry/cold conditions for the late Glacial probably represents the Younger Dryas period. From the beginning of the Holocene at around $11 \mathrm{ka}$ cal BP wet conditions prevailed until about $3.5 \mathrm{ka}$ cal BP, interrupted by three dry /cold reversals. Since $3.5 \mathrm{ka}$ cal BP aridity increased, leading to a higher dune activity and lake desiccation. The results of this investigation show a general consistence with palaeoclimatic data from surrounding regions of central Asia. Due to a different initiation and characteristic of climatic events as well as different regional influences within central Asia a comparison to short term climatic changes in northern Mongolia, Russia and China is not always possible. Our study underlines the need of further detailed studies of well selected lake archives of small catchment areas to reconstruct the complex spatial climatic pattern of central Asia being concurrently controlled by the westerlies and the monsoon system. Therefore, and to understand the role of climate phenomena known from oceanic regions, further studies are required especially in continental Mongolia.

\section{Acknowledgements}

We thank the German Research Foundation (Deutsche Forschungsgemeinschaft, DFG) for funding of the project "Late Pleistocene, Holocene and ongoing geomorphodynamics in the Gobi Desert; South Mongolia" (LE 730/16-1). Field work was supported by the Mongolian Academy of Sciences (Prof. D. Dorjgotov, A. Tschimegsaichan). Palynological analyses and datings were financed by a scholar ship from the Kohat University of Science and Technology, Pakistan, to Waheed Murad. We especially thank Serd-Yanjiv Narangerel for help during field work. The AMS analyses were carried out by the AMS ${ }^{14} \mathrm{C}$ Laboratory of the University Erlangen.

\section{References}

Administration of Land Affairs, G. a. C. 2004. Geographic Atlas of Mongolia. Ulaanbaatar.

Andreev, A. A., Tarasov, P. E. 2007. Postglacial Pollen Records of Northern Asia. Encyclopedia of Quaternary Science. 2721-2730. Elsevier.

Baasan, T. 2004. Aeolian sands of Mongolia. Munkhiin useg Co.,Ltd., Ulaanbaatar.

Banks, D., Parnachev, V. P., Frengstad, B., Holden, W., Karnachuk, O. V., Vedernikov, A. A. 2004. The evolution of alkaline, saline ground- and surface waters in the southern Siberian steppes. Applied Geochemistry 19: 1905-1926.

Barthel, H. 1988. Mongolei - Land zwischen Taiga und Wüste. VEB Hermann Haack, Gotha. 
Beug, H. - J., 2004. Leitfaden der Pollenbestimmung für Mitteleuropa und angrenzender Gebiete. Pfeil, München.

Chen, C. A., Lan, H., Lou, J., Chen, Y. 2003. The Dry Holocene Megathermal in Inner Mongolia. Palaeogeography, Palaeoclimatology, Palaeoecology 193: 181-200.

Chen, F., Wu, W., Holmes, J., Madsen, D., Zhu, Y., Jin, M., Oviatt, C. 2003. A mid-Holocene drought interval as evidenced by lake desiccation in the Alashan Plateau, Inner Mongolia China. Chinese Science Bulletin 48: 1401-1410.

Chen, F., Cheng, B., Zhao, Y., Zhu, Y., Madsen, D. B. 2006. Holocene environmental change inferred from a high-resolution pollen record, Lake Zhuyeze, arid China. The Holocene 16: 675684.

Chen, F., Yu, Z., Yang, M., Ito, E., Wang, S., Madsen, D. B., Huang, X., Zhao, Y., Sato, T., B., J., Birks, H., Boomer, I., Chen, J., An, C., Wünnemann, B. 2008. Holocene moisture evolution in arid central Asia and its out-of-phase relationship with Asian monsoon history. Quaternary Science Reviews 27: 351-364.

Erdtman, G., 1960. The acetolysis method. Svensk Botanisk Tidskrift 54, 561-564.

Fedotov, A., Bezrukova, E., Chebykin, E., Khlystov, O., Krapivina, S., Levina, O., Mazepova, G., Mizandrontsev, I., Semenov, A., Vorobyova, S., Zheleznyakova, T., Grachev, M. 2000. Potential value of bottom sediments of Lake Khuvsgul (Mongolia) for paleoclimate reconstructions. Berliner geowissenschaftliche Abhandlungen A: 107-112.

Feng, Z., Wang, W. G., Guo, L. L., Khosbayar, P., Narantsetseg, T., Jull, A. J. T., An, C. B., Li, X. Q., Zhang, H. C., Ma, Y. Z. 2005. Lacustrine and eolian records of Holocene climate changes in the Mongolian Plateau: preliminary results. Quaternary International 136: 25-32.

Fowell, S., Hansen, B., Peck, J., Khosbayar, P., Ganbold, E. 2003. Mid to late Holocene climate evolution of the Lake Telmen Basin, North Central Mongolia, based on palynological data. Quaternary Research 59: 353-363.

Gillespie, A. R., Burke, R. M., Komatsu, G., Bayasgalan, A. 2008. Late Pleistocene glaciers in Darhad Basin, northern Mongolia. Quaternary Research 69: 169-187.

Grubov, V. I., 2001. Key to the vascular plants of Mongolia. Vol. $1+2$. Science Publ., Enfield.

Grunert, J., Dasch, D. 2000. Paleoclimatic implications of dunes in the Uvs Nuur-Basin, Western Mongolia. Berliner geowissenschaftliche Abhandlungen A: 2-8.

Grunert, J., Lehmkuhl, F., Walther, M. 2000. Paleoclimatic evolution of the Uvs Nuur basin and adjacent areas (Western Mongolia). Quaternary International 65-66: 171-192.

Grunert, J., Lehmkuhl, F. 2004. Aeolian sedimentation in arid and semi-arid environments of Western Mongolia. Paleoecology of Quaternary Drylands: - Lecture Notes in Earth Sciences 102: 195-218. 
Grunert, J. Stolz, C., Hempelmann, N., Hilgers, A., Hülle, D., Lehmkuhl, F., Felauer, T., Dasch, D. 2009. The evolution of small lake basins in the Gobi desert in Mongolia. Quaternary Sciences, Beijing. Submitted for publication.

Guo, L., Feng, Z., Li, X., Liu, L., Wang, L. 2007. Holocene climatic and environmental changes recorded in Baahar Nuur Lake core in the Ordos Plateau, Inner Mongolia of China. Chinese Science Bulletin 52: 959-966.

Hartmann, K., Wünnemann, B., 2009. Hydrological changes and Holocene climate variations in NW China, inferred from lake sediments of Juyanze palaeolake by factor analyses. Quaternary International 194: 28-44.

Hempelmann, N. 2011. Aeolian geomorphodynamics in endorheic basins of the Mongolian Gobi Desert. Mainz.

Herzschuh, U. 2006. Palaeo-moisture evolution in monsoonal Central Asia during the last 50,000 years. Quaternary Science Reviews 25: 163-178.

Herzschuh, U., Zhang, C., Mischke, S., Herzschuh, R., Mohammadi, F., Mingram, B., Kürschner, H., Riedel, F. 2005. A late Quaternary lake record from the Quilian Mountains (NW China): evolution of the primary production and the water depth reconstructed from macrofossil, pollen, biomarker, and isotope data. Global and Planetary Change 46: 361-379.

Hilbig, W., 1995. The vegetation of Mongolia. SPB Academic Publishing, Amsterdam.

Horiuchi, K., Minoura, K., Hoshino, K., Oda, T., Nakamura, T., Kawai, T. 2000. Paleoenvironmental history of Lake Baikal during the last 23000 years. Paleogeography, Paleoclimatology, Paleoecology 157: 95-108.

Jiang, Q., Shen, J., Liu, X., Zhang, E., Xiao, X. 2007. A high-resolution climatic change since Holocene inferred from multi-proxy of lake sediment in westerly area of China. Chinese Science Bulletin 52: 1970-1979.

Jin, Z., Li, F., Cao, J., Wang, S., Yu, J. 2006. Geochemistry of Daihai Lake sediments, Inner Mongolia, north China: Implications for provenance, sedimentary sorting, and catchment weathering. Geomorphology 80: 147-163.

Juggins, S., 2007. C2 Version 1.5 User guide. Software for ecological and palaeoecological data analysis and visualisation. University of Newcastle, Newcastle upon Tyne, UK.

Kilibarda, Z., Argyilan, E., and Blockland, J. 2008. Wind deposition of mud aggregates and their role in development of lamellae in the Fair Oaks Dunes, Indiana. CATENA 72, 235 - 247.

Komatsu, G., Brantingham, P. J., Olsen, J. W., Baker, V. R. 2001. Paleoshoreline geomorphology of Boon Tsagaan Nuur, Tsagaan Nuur and Orog Nuur: the Valley of Lakes, Mongolia. Geomorphology 39: 83-98.

Krengel, M. 2000. Discourse on history of vegetation and climate in Mongolia - palynological report of sediment core Bayan Nuur I (NW-Mongolia). Berliner geowissenschaftliche Abhandlungen A: 80-84. 
Lehmkuhl, F. 1997. The spatial distribution of loess and loess-like sediments in the mountain areas of Central and High Asia. Zeitschrift für Geomorphologie Suppl. Band 111: 97-116.

Lehmkuhl, F. 1998. Quaternary glaciations in Central and Western Mongolia. Quaternary Proceedings 6: $153-167$.

Lehmkuhl, F. 2000. Alluvial fans and pediments in Western Mongolia and their implications for neotectonic events and climate change. Berliner geowissenschaftliche Abhandlungen A: $14-21$.

Lehmkuhl, F., Klinge, M., Rees-Jones, J., and Rhodes, E. J. 2000. Late Quaternary aeolian sedimentation in central and south-eastern Tibet. Quaternary International 68-71: 117-132.

Lehmkuhl, F., Lang, A. 2001. Geomorphological investigations and luminescence dating in the southern part of the Khangay and the Valley of the Gobi Lakes (Central Mongolia). Journal of Quaternary Science 16: 69-87.

Litt, T., Stebich, M. 1999: Bio- and chronostratigraphy of the lateglacial in the Eifel region, Germany. Quaternary International 61: 5-16.

Melles, M., Brigham-Grette, J., Glushkova, O. Y., Minyuk, P., Nowaczyk, N., and Hubberten, H. 2007. Sedimentary geochemistry of core PG1351 from Lake El'gygytgyn - a sensitive revord of climate variability in the East Siberian Arctic during the past three glacialinterglacial cycles. Journal of Paleolimnology 37: 89-104.

Mineral Resources Authory of Mongolia; Mongolian Academy of Sciences 1998. Geological map of Mongolia. Ulaanbaatar.

Mischke, S., Demske, D., Schudack, E. 2003. Hydrologic and climatic implications of a multidisciplinary study of the mid to late Holocene Lake Eastern Juyanze. Chinese Science Bulletin 48: 1411-1417.

Mischke, S., Herzschuh, U., Zhang, C., Bloemendal, J., Riedel, F. 2005. A Late Quaternary lake record from the Qilian Mountains (NW China): lake level and salinity changes inferred from sediment properties and ostracod assemblages. Global and Planetary Change 46: 337-359.

Moore, P. D., Webb, J. A., Collinson, M. E., 1999. Pollen analysis. Blackwell Science, Oxford.

Morrill, C., Overpeck, J. T., Cole, J. E., 2003. A synthesis of abrupt changes in the Asian summer monsoon since the last deglaciation. The Holocene 13, 465.

National Statistical Office of Mongolia 2004. Mongolian Statistical Yearbok 2003. Ulaanbaatar.

Naumann, S. 1999. Spät- und postglaziale Landschaftsentwicklung im Bajan Nuur Seebecken (Nordwestmongolei). Die Erde 130: 117-130.

Owen, L. A., Windley, B. F., Cunningham, W. D., Badamgarav, J., Dorjnamjaa D., 1997. Quaternary alluvial fans in the Gobi of southern Mongolia: evidence for neotectonics and climate change. Journal of Quaternary Science 12: 239-252. 
Owen, L. A., Richards, B., Rhodes, E. J., Cunningham, W. D., Windley, B. F., Badamgarav, J., Dorjnamjaa, D. 1998. Relic permafrost structures in the Gobi of Mongolia: age and significance. Journal of Quaternary Science 13: 539-547.

Pachur, H., Wünnemann, B., Zhang, H. 1995. Lake Evolution in the Tengger Desert, Northwestern China, during the Last 40,000 Years. Quaternary Research 44: 171-180.

Peck, J. A., Khosbayar, P., Fowell, S., Pearce, R., Ariunbileg, S., Hansen, B., Soninkhishig, N. 2002. Mid to Late Holocene climate change in north central Mongolia as recorded in the sediments of Lake Telmen. Paleogeography, Paleoclimatology, Paleoecology 183: 135153.

Peng, Y., Xiao, J., Nakamura, T., Liu, B., and Inouchi, Y. 2005. Holocene East Asian monsoonal precipitation pattern revealed by grain-size distribution of core sediments of Daihai Lake in Inner Mongolia of north-central China. Earth and Planetary Science Letters 233: 467479.

Prins, M. A., Postma, G., Cleveringa, J., Cramp, A., Kenyon, N. H. 2000. Controls on terrigenous sediment supply to the Arabian Sea during the late Quaternary: the Indus Fan. Marine Geology 169: 327-349.

Prokopenko, A. A., Khursevich, G. K., Bezrukova, E. V., Kuzmin, M. I., Boes, X., Williams, D. F., Fedenya, S. A., Kulagina, N. V., Letunova, P. P., Abzaeva, A. A. 2007. Paleoenvironmental proxy records from Lake Hovsgol, Mongolia, and a synthesis of Holocene climate change in the Lake Baikal watershed. Quaternary Research 68: 2-17.

Rahmstorf, S., 2003. Timing of abrupt climate change: A precise clock. Geophys. Res. Lett. 30, 171 174.

Rickettsa, R.D., Johnsona, T.C., Browna, E.T., Rasmussenb, K.A., Romanovskyc, V.V., 2001. The Holocene paleolimnology of Lake Issyk-Kul, Kyrgyzstan: trace element and stable isotope composition of ostracodes. Palaeogeography, Palaeoclimatology, Palaeoecology 176, 207 227

Scheffer, F., Schachtschabel, P. 2002: Lehrbuch der Bodenkunde. 15. Auflage. Heidelberg; Berlin: Spektrum Akademischer Verlag.

Schettler, G., Liu, Q., Mingram, J., Stebich, M., Dulski, P. 2006. East-Asian monsoon variability between 15000 and 2000 cal. yr BP recorded in varved sediments of Lake Sihailongwan (northeastern China, Long Gang volcanic field). The Holocene 16: 1043-1057.

Schlütz, F. 2000. Palynological investigations in the Turgen-Kharkhiraa mountains, Mongolian Altay. Berliner geowissenschaftliche Abhandlungen A: 85-90.

Schlütz, F., Lehmkuhl, F., 2007. Climatic change in the Russian Altai, southern Siberia, based on palynological and geomorphological results with implications on teleconnections and human history since the middle Holocene. Vegetation History and Archaeobotany 16, 101118. 
Schlütz, F., Miehe, G., Lehmkuhl, F., 2007. Zur Geschichte des größten alpinen Ökosystems der Erde: Palynologische Untersuchungen zu den Kobresia-Matten SE-Tibets. Berichte der Reinhold-Tüxen-Gesellschaft 19, 23-36.

Schwanghart, W., Schütt, B., Walther, M. 2008. Holocene Climate Evolution of the Ugii Nuur Basin, Mongolia. Advances in atmospheric sciences 25: 986-998.

Singer, S., Avery, D., 2005. The Physical Evidence of Earth's Unstoppable 1,500-Year Climate Cycle. NCPA Policy Report No. 279, 1-27.

Stebich, M., Mingram, J., Han, J., Liu, J., 2009. Late Pleistocene spread of (cool-) temperate forests in Northeast China and climate changes synchronous with the North Atlantic region. Global and Planetary Change 65, 56-70.

Stuiver, M, Polach, H. A., 1977. Discussion reporting 14C data. Radiocarbon 19, 355-363

Tarasov, P. 2000. Holocene vegetation and climate changes in Hoton-Nur basin, northwest Mongolia. Boreas 29: 117-126.

Tomkins, J., Lamoureux, S., Antoniades, D., Vincent, W. 2005. Long-term water balance variability in Lake A, northern Ellesmere Island.

van Geel, B., Buurman, J., Brinkkemper, O., Schelvis, J., Aptroot, A., van Reenen, G., Hakbijl, T., 2003. Environmental reconstruction of a Roman Period settlement site in Uitgeest (The Netherlands), with special reference to coprophilous fungi. Journal of Archaeological Science 30, 873-884.

Vánky, K., 1994. European smut fungi. Fischer, Stuttgart.

Vassallo, R., Ritz Jean-Francois; Braucher, Braucher, R., Carretier, S. 2005. Dating faulted alluvial fans with cosmogenic 10Be in the Gurvan Bogd mountain range (Gobi-Altay, Mongolia): climatic and tectonic implications. Terra Nova 17: 278-285.

Walther, M. 1999. Befunde zur jungquartären Klimaentwicklung rekonstruiert am Beispiel der Seespiegelstände des Uvs Nuur-Beckens (NW-Mongolei). Die Erde 130: 131-150.

Walther, M., Wünnemann, B., Tschimeksaichan, A. 2003. Seen und Paläoseen in der Mongolei und Nordwestchina. Petermanns Geographische Mitteilungen 147: 40-47.

Wang, W., Feng, Z., Lee, X., Zhang, H., Ma, Y., An, C., Guo, L. 2004. Holocene abrupt climate shifts recorded in Gun Nuur lake core, northern Mongolia. Chinese Science Bulletin 49: 520526.

Wang, W., Ma, Y., Feng, Z., Meng, H., Sang, Y., and Zhai, X. 2009. Vegetation and climate changes during the last 8660 cal. a BP in central Mongolia, based on a high-resolution pollen record from Lake Ugii Nuur. Chinese Science Bulletin 54: 1579-1589.

Weninger, B., Jöris, O., 2008. A ${ }^{14} \mathrm{C}$ age calibration curve for the last $60 \mathrm{ka}$ : the Greenland-Hulu U/Th timescale and its impact on understanding the Middle to Upper Paleolithic transition in Western Eurasia. Journal of Human Evolution 55, 772-781. 
Wünnemann, B., Pachur, H. J., Jijun, L., Hucai, Z. 1998. Chronologie der pleistozänen und holozänen Seespiegelschwankungen des Gaxun Nur / Sogo Nur und Baijian Hu, Innere Mongolei, Nordwestchina. Petermanns Geographische Mitteilungen 142: 191-206.

Wünnemann, B., Chen, F., Riedel, F., Zhang, C., Mischke, S., Chen, G., Demske, D., Ming, J. 2003. Holocene lake deposits of Bosten Lake, southern Xinjiang, China. Chinese Science Bulletin 48: 1429-1432.

Yang, X., Rost, K. T., Lehmkuhl, F., Zhenda, Z., Dodson, J. 2004. The evolution of dry lands in northern China and in the Republic of Mongolia since the Last Glacial Maximum. Quaternary International 118-119: 69-85. 


\title{
Chapter 4
}

\section{High resolution pollen record from lake Orog Nuur, southwestern Mongolia: An evidence for climate history during the last $50 \mathrm{ka}$}

\author{
Waheed Murad, Frank Schlütz, Thomas Felauer, Stefen Mischke, Frank Lehmkuhl
}

\begin{abstract}
High resolution pollen and non pollen palynomorphs records from the sediments of lake Orog Nuur, located in the semiarid Gobi-Altai transition zone in the valley of lakes, was used to reconstruct vegetation and climate history during late Quaternary. This paper provides a record of climate change for this key region located on the margin of summer monsoon and westerlies. The palynological results indicate that the pollen of Artemisia and Chenopodiaceae dominate the whole profile during the last 50 ka cal BP. Seven major episodes of climate change are reconstructed in the record in response to palaeovegetation. Artemisia steppe desert prevailed between 49.5 and $44.7 \mathrm{ka}$ cal BP, indicating relatively warm (interstadial) and semi humid conditions correlating to Marine Oxygen Isotope stage 3 (MIS 3). Relatively dry and cool climate is dated between 44.7 to $23.2 \mathrm{ka}$ cal BP corresponding to Marine Oxygen Isotope stage 2 (MIS 2). It is followed by a rise of temperature with semi arid conditions between 23.2 and $22.7 \mathrm{ka}$ cal BP. This interval indicates the initiation of glacier retreat during the early kataglacial stage (late glacial times). The aridity of the climate was still in progress from $22.7 \mathrm{ka}$ cal BP till the late Holocene. From about $18.9 \mathrm{ka}$ cal BP, xeromorphic taxa increased in abundance, indicating that the conditions became arid and cold. The further decrease in precipitation and changes in the vegetation towards desert are reflected by the increase in the frequency of Chenopodiaceae and Ephedra shrubs from about $11 \mathrm{ka}$ cal BP.
\end{abstract}

More high resolution palaeovegetation and palaeoclimate data is needed to observe short lived events.

Key words: Late Quaternary, pollen, vegetation and climate history, Gobi-Altai

\section{Introduction}

Mongolia is a part of the arid to semiarid Asian region. This region is controlled by the Asian monsoon and the North Atlantic Oscillation (NAO) associated westerlies (Visbeck, 2002; Vandenberghe et al., 2006; Wang et al., 2009). These westerly winds affect the northern and western part of Central Asia and bring moisture to the Mongolian and Gobi Altai of southwestern Mongolia (Lehmkuhl and Haselein, 2000). Herzschuh (2006) proposed that Mongolia represents a transitional zone between the circulation system of summer monsoon and westerlies whereas Chen et al. (2008) stated that the westerlies are a dominating climate system for Mongolia. The geographical location of 
Mongolia and sedimentary records from this region would be a central key to understand past vegetation and climate changes, owing to the mid-latitude westerlies.

The variations in the intensity of the Mongolian High Pressure System (MHPS) in southern Mongolia during late Quaternary times (Owen et al., 1997) draw attention of palaeoecologists. The MHPS has a strong control on the regional climate of Central Asia and drives strong westerlies in the Gobi desert and adjacent regions (Owen et al., 1997; Herzschuh, 2006). In order to understand the interacting history of NAO, MHPS and Asian monsoon climate systems, a detailed reconstruction of late Quaternary palaeoenvironment including past vegetation and climate change in the southern Mongolia is urgently needed.

Several multi-proxy studies have been carried out during the last decade in northwestern and central Mongolia (Grunert et al., 2000; Peck et al., 2002; Fowell et al., 2003; Wang et al., 2004; Feng et al., 2007; Prokopenko et al., 2007; Schlütz et al., 2008; Rudaya et al., 2009; Wang et al., 2009, 2011). Most of these studies are focused only on Holocene vegetation and climate history. These records brought contradictory ideas about Holocene vegetation and climate change and their driving forces. Therefore, more work is emphasized to assess the stability of Holocene and late Quaternary vegetation and climate reconstruction. Pollen records from lakes in the arid and semi arid regions of Mongolia are one of the best proxies for vegetation history and environmental response to the global climate change.

In general it has to be considered that studies on late Quaternary vegetation and climate in Mongolia are still rare and are mostly based on poorly dated pollen records (Gunin et al., 1999). In this paper, a detailed reconstruction of vegetation and climate changes during the late Quaternary is presented by a first high-resolution pollen record from lake Orog Nuur (ONW) in southwestern Mongolia.

\section{Regional setting}

\subsection{Geography}

Mongolia is situated in the northern part of Central Asia and has an area of more than 1,500,000 $\mathrm{km}^{2}$, with an average population density of less than two people per $\mathrm{km}^{2}$ (Rudaya et al., 2009; Dulamsuren et al., 2010). It stretches 1,259 km from North to South and 2,392 km from East to West (Fig. 4.1). It has a net work of the Hangai and Hentii Mountains in the North and Khangai Mountains in central Mongolia. The Mongolian Altai lies in the West and the Gobi Altai is in the Southeast of the country (Johnson et al., 2006).

\subsection{Current climate}

The continental climate of Mongolia receives low precipitation and is far away from the Oceanic influences. The mean annual country wide precipitation is only $230 \mathrm{~mm}$ and about $90 \%$ of the 
precipitation is returned to the atmosphere through evapotranspiration. Only $3 \%$ of the total annual precipitation is potentially available as soil moisture. Mean annual precipitation decreases from the Northwest to the Southeast. The annual highest precipitation values, exceeding $600 \mathrm{~mm}$, is recorded locally in the Hovsgol region of northwestern Mongolia while the Southeast Gobi desert receives the lowest annual precipitation of about $50 \mathrm{~mm}$ (Batjargal, 1997; Ma et al., 2008). The summer temperature is high and consequently high moisture deficit occurs during the vegetation period. The

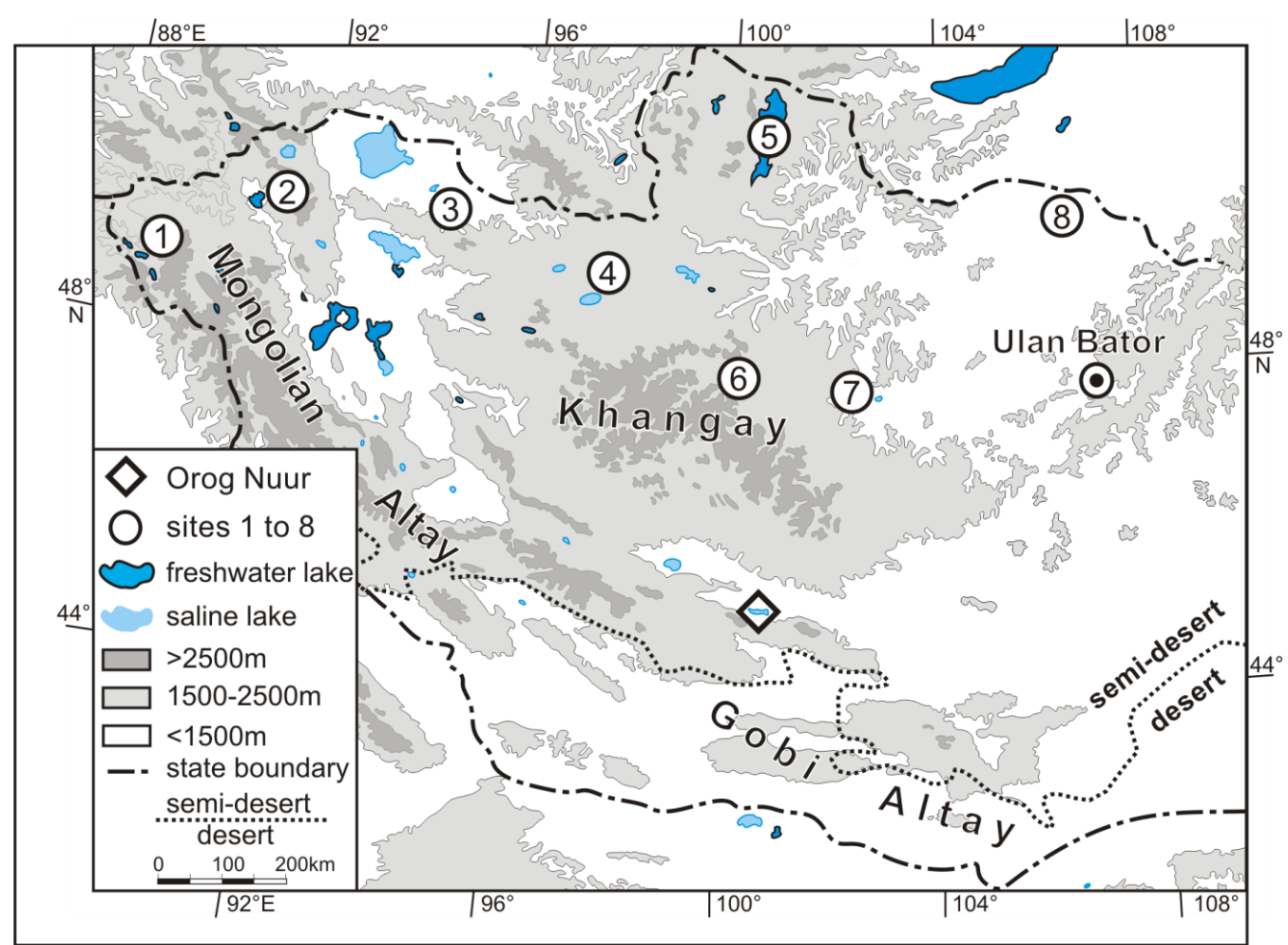

Fig. 4. 1. Map of Mongolia with investigation sites mentioned in the text and the transition line from desert to semi-desert (Artemisia steppe). Sites mentioned in the text are: 1. Hoton Nuur (Rudaya et al., 2009) 2. Archit Nuur (Gunin et al., (eds.) 1999) 3. Bayan Nuur (Grunurt et al., 2000) 4. Telmen Nuur (Fowell et al., 2003; Peck et al., 2002) 5. Hovsgol Nuur (Prokopenko et al., 2007) 6. Daba Nuur (Gunin et al., (eds.) 1999) 7. Ugii Nuur (Wang et al., 2009; Wang et al., 2011) 8. Gun Nuur (Wang et al., 2004).

mean annual temperature is about -2 to $5{ }^{\circ} \mathrm{C}$ with low average temperature of $-24{ }^{\circ} \mathrm{C}$ in January and high average temperature of $22{ }^{\circ} \mathrm{C}$ in July (Ariunsuren et al., 2009). The climate becomes drier and warmer from the Northwest to the Southeast. Strong winds, with relative low air humidity and very low precipitation, are blowing during the spring time. A fierce dust and sand storms are observed during the early afternoon hours (Tuvdendorzh and Myagmarzhav, 1985). 


\subsection{Current vegetation}

The major part of Mongolia covers the steppe and forest-steppe zones. The Mongolian steppe represents one of the largest contiguous unaltered grasslands in the world (Bedunah et al., 2006; Ma et al., 2008). More than 70\% of Mongolia's forest is covered by Larix sibirica (Gunin et al., 1999). Forests are mostly found in the northern and eastern slopes of high mountains. Grasslands dominate the sun exposed southern and western slopes, whereas steppe vegetation covers the plains; such areas are classified as forest steppe. Steppes also occur on sun exposed slopes of the mountain taiga, north of the forest steppe belt (Dulamsuren et al., 2005). The distribution of major vegetation zones is controlled by variations in altitude, temperature, rainfall distribution and soils of Mongolia. Based on these different climatic and environmental factors, the vegetation of Mongolia follows north-south gradient with alpine tundra (3\%) in the North, followed by mountain taiga (4\%), mountain steppe and forest steppe (25\%), grass steppe (26\%), desert steppe (27\%) and desert (15\%) in the South (Dulamsuren et al., 2005; Bedunah et al., 2006; Johnson et al., 2006).

\subsection{Study site}

Lake Orog Nuur is located at $45^{\circ} 2^{\prime} 60 \mathrm{~N}$ longitude and $100^{\circ} 42^{\prime} 0 \mathrm{E}$ latitude in the valley of Gobi lakes (Fig. 4. 2). The studied lake currently covers an area of approximately $129 \mathrm{~km}^{2}$ and is situated at about $1280 \mathrm{~m}$ in elevation. The climatic conditions in the lake region have winter temperatures below $20{ }^{\circ} \mathrm{C}$ and summer temperatures exceeding $15^{\circ} \mathrm{C}$. Mean January temperature of Bayankhongor at 1900 m elevation is $-18.3{ }^{\circ} \mathrm{C}$ and mean July temperature is $16.3^{\circ} \mathrm{C}$. The mean annual precipitation is usually $<150 \mathrm{~mm}$, exceeding $400 \mathrm{~mm}$ in the surrounding higher mountain areas of the valley (Academy of Sciences of Mongolia and Academy of Sciences of USSR, 1990; Komatsu et al., 2001; Lehmkuhl and Lang, 2001; Yang et al., 2004).

The valley is bounded by the Khangai Mountains to the northeast of the study site and the Altai Mountains to the southwest. The largest mountainous range of Mongolia, the Mongolian Altai, lies in the north-western part of the valley. The valley has a net work of many other lakes namely Boon Tsagaan Nuur, Taatsyn-Tsagaan Nuur and Ulaan Nuur. Lake Orog Nuur is fed by the river Tüin Gol from the Khangai mountain range (Komatsu et al., 2001; Lehmkhul and Lang, 2001; Yang et al., 2004). The valley and its surrounding mountain ranges comprise a wide variety of terrestrial and an aquatic habitats but very little is known about the vegetation and climate history of the region. The highest peaks of the Khangai mountain range is covered by Salix (willow), Potentila fruiticosa, Betula (birch), Pinus sibirica (Siberian stone pine) and Larix (larch). The lower slopes and plains in the northern part of the valley are located in window shadow and has dry desert climate. These slopes contain a mixture of high mountains and steppe vegetation whereas the plains are characterized by desert steppe with such as Chenopodiaceae, Artemisia absinthium and Poaceae. The plains are dissected deeply by small rivers originating from Khangai mountain range and enter to Orog Nuur. Sedges and forb-sedges communities are growing on flood plains. In the meadow steppe, cushion 
plants with Kobresia and Carex form the major vegetation types of the Mongolian Altai. Its north facing slopes are covered by very sparse patches of Larix stands but the southwestern slopes have small forest fragments of Larix, Pinus sibirica and Picea (spruce) species (Gunin et al., 1999; Miehe et al., 2007).

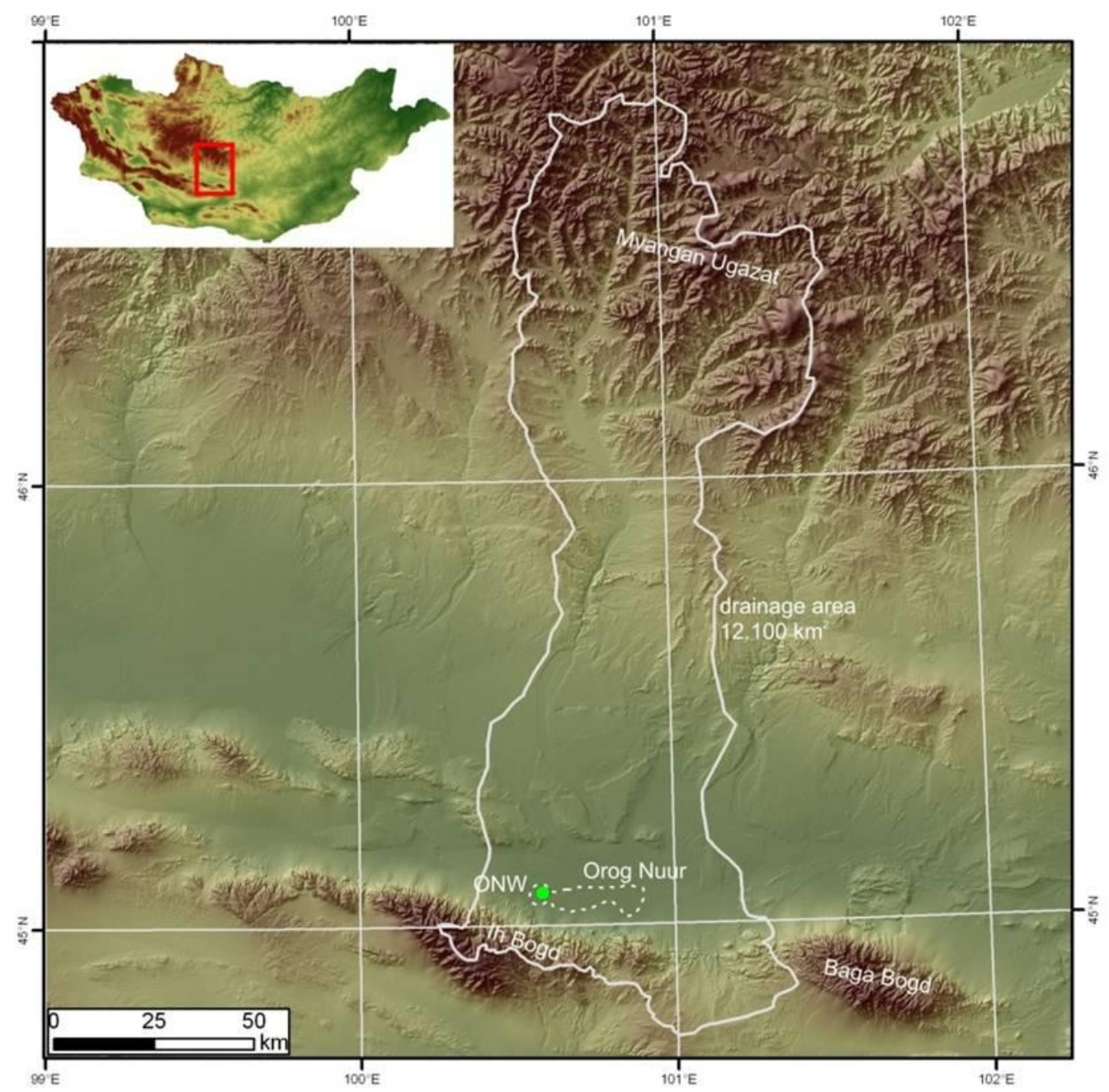

Fig. 4. 2. Map of Mongolia showing the investigation site (Orog Nuur)

The southern part of the valley is limited by tectonic escarpment of the Gobi Altai with gently inclined plains, sandy hills and intermittent Orog Nuur. Desert steppe taxa such as feather grass (Poaceae) - onion (Allium polyrrhizum) at inclined plains, wormwood (Artemisia) - dwarf bushes in sandy hills and Reed-halophytes are common plant communities near Orog Nuur. Semi fixed stands with single Haloxylon (Chenopodiaceae) trees are observed along Orog Nuur. Such a landscape feature reflects that the lake was formerly occupying a very large area and is now desiccating (Gunin et al., 1999). The intermountain basins of Gobi Altai are dominated by desert steppe such as Stipa species, Anabasis brevifolia and Allium polyrrhizum. At high altitude between 2300-2700 m the vegetation changed to mountain steppe like Stipa krylovii, Artemisia frigida and Agropyron cristatum. The Betula 
and Salix forests are bordered by a narrow belt of meadow steppe. Betula is found occasionally, pointing the replacement of forest by meadow steppe (Miehe et al., 2007).

Due to water deficit the density of human population in the valley is very low and mostly employed in cattle ranching (Dgebuadze, 1995). Despite very harsh conditions many pastoral nomads find a livelihood with their herds of camels, sheep and goats in these semi desert regions. Desert feather grasses and various types of pea shrubs provide grazing to livestock. The wild camel and the saiga antelope which is found here are some of the rarest species in the world (Onon et al., 2004).

\section{Materials and methods}

A 1333-cm-long sediment core was drilled in the dried out western part of the lake Orog Nuur (ONW). Sediment samples of 1 or $2 \mathrm{~cm}^{3}$ were taken for pollen analyses at 5 to $10 \mathrm{~cm}$ intervals along the core. In total 123 samples were obtained and treated with $\mathrm{KOH}, \mathrm{HCl}, \mathrm{HF}$ and acetolysis. The pollen grains were extracted with standard techniques (Erdtman, 1960; Moore et al., 1999). Before processing Lycopodium spores were added as exotic marker to calculate the pollen concentration $\left(\right.$ grains $/ \mathrm{cm}^{3}$ ) and pollen influx (grains $/ \mathrm{cm}^{2} / \mathrm{yr}$ ) as well as spores and charcoal particles. The suspensions were sieved in an ultrasonic bath through a $1.5 \mu \mathrm{m}$ mesh and stored in glycerin.

At least 400 pollen grains, excluding Cyperaceae, aquatic pollen and spores, were counted in each pollen sample. However, pollen concentration in few samples was low, but the number of counted pollen reaches at least 200 per sample. A total of 50 pollen and 40 spore types were identified. Pollen clumps, denoting immature pollen grains sticking together, were also observed as palaeoecological parameter (Schlütz and Lehmkuhl, 2007). Pollen and spore types were identified with available literature (Vanky, 1994; Moore et al., 1999; Van Geel et al., 2003; Beug, 2004) and the reference collection of the Department of Palynology and Climate Dynamics in Göttingen. The identified taxa were grouped into Arboreal plants (AP), pollen and spores indicating humid conditions, grazing, soil erosion and aquatic environment.

Amaranthaceae/Chenopodiaceae $(\mathrm{A} / \mathrm{C})$ ratios were calculated for the pollen record. $\mathrm{A} / \mathrm{C}$ ratio in arid and semi arid areas of Asia help to distinguish steppe and desert vegetation based on pollen analyses and used it as a moisture indicator (El-Moslimany, 1990). This approach is based on the observation that higher Chenopodiaceae percentages characterize desert plants while higher Artemisia percentages point to steppe vegetation (Herzschuh et al., 2006a).

The software $\mathrm{C} 2$ version 1.5.1 was used to plot a percentage diagram of the selected palynological data (Juggins, 2007). The pollen and spore taxa are arranged according to their ecology and chronological sequence. The pollen and spore types that appeared in more than 3 samples throughout the record or having values above $0.50 \%$ are displayed in the pollen diagram. 


\section{Chronology}

The age depth model is based on eight bulk samples obtained for AMS ${ }^{14} \mathrm{C}$ dates (Tab. 4.1). All the bulk samples were determined at the Accelerator Mass Spectrometry (AMS) laboratory of the University of Erlangen, Germany. The ages were calibrated with online program CalPal (http://www.calpal-online.de/CalPal2007-HULU; Weninger and Jöris, 2008). The temporary desiccating lake should be in an isotopic equilibrium with the atmosphere by intense $\mathrm{CO}_{2}$ interchange. The low amounts of $\delta^{13} \mathrm{C}$ point to a predominantly terrestrial origin of the dated carbon as remarkable contributions of water plants to the dated material could be identified by higher $\delta^{13} \mathrm{C}$ values (Herzschuh et al 2005; Stuiver and Polach 1977). Keeping in view the aforementioned facts, all dating results seem to be more or less free of the reservoir effect. Therefore the age depth model represents an interpolation of the eight AMS dates and an assumed recent surface age (Fig. 4.3). The age inversion at $1192 \mathrm{~cm}$ and $1272 \mathrm{~cm}$ can be caused by the limit of the AMS method and the increased deviation of the measured ages.

\begin{tabular}{|l|l|l|l|l|l|}
\hline Depth [cm] & Lab. No & $\begin{array}{l}14 \mathrm{C} \text { age and } \\
\text { error [yr. BP] }\end{array}$ & $\delta^{13} \mathrm{C}[\%$ ] & $\begin{array}{l}\text { Calibrated } \\
\text { age and SD } \\
\text { [cal. yr. BP] }\end{array}$ & material \\
\hline 94 & ERL-15622 & $12581 \pm 103$ & $-25,4$ & $12973 \pm 323$ & bulk sample \\
\hline 199 & ERL-15623 & $13242 \pm 85$ & $-24,2$ & $14223 \pm 413$ & bulk sample \\
\hline 271 & ERL-15624 & $17733 \pm 149$ & $-25,4$ & $19215 \pm 354$ & bulk sample \\
\hline 392 & ERL-15625 & $17713 \pm 180$ & $-24,5$ & $19192 \pm 379$ & bulk sample \\
\hline 571 & ERL-15626 & $19738 \pm 179$ & $-23,8$ & $21670 \pm 348$ & bulk sample \\
\hline 778 & ERL-15627 & $21501 \pm 217$ & $-24,2$ & $23714 \pm 444$ & bulk sample \\
\hline 1192 & ERL-15628 & $46103 \pm 2281$ & $-25,4$ & $48072 \pm 3111$ & bulk sample \\
\hline 1272 & ERL-15629 & $40429 \pm 1340$ & $-25,92$ & $42241 \pm 1147$ & bulk sample \\
\hline
\end{tabular}

Tab. 4.1. Results of the AMS ${ }^{14} \mathrm{C}$-datings and their calendric age-conversion (calibration) with $1 \sigma$ standard deviation (SD) using "CalPal-online" (Weninger and Jöris 2008).

\section{Results and interpretation}

\subsection{Pollen analyses}

Seven pollen zones (ONW 1-7) are recognized based on variations in the pollen stratigraphy and the deduced palaeoecological changes (Fig. 4.4). Artemisia and Chenopodiaceae are the most common pollen which occurs throughout the diagram. Both pollen taxa together constitute more than $65 \%$ per sample, exceeding up to $90 \%$ in zone ONW 3 and ONW 5. Ephedra shows high frequency in the upper two zones. Poaceae and Liguliflorae have a constant existence of ca. 4-7\% through the whole record. Caryophyllaceae, Brassicaceae and the Hippophaë-type pollen gradually disappear to missing in pollen zone ONW 6 and ONW 7 respectively. Arboreal pollen such as Quercus, Nitraria, Salix and the Pinus Haploxylon-type occur regularly in low percentages $(<1 \%)$. The green algae Botryococcus and Pediastrum are recorded frequently in zones ONW 3 and ONW 5 where as Volvocaceae and Sparganium dominate in the upper two zones. Mandibles of Chironomids are mainly found in the 
sediment samples of ONW 3. Brief characteristics of the ONW pollen zones from bottom to top are given below.

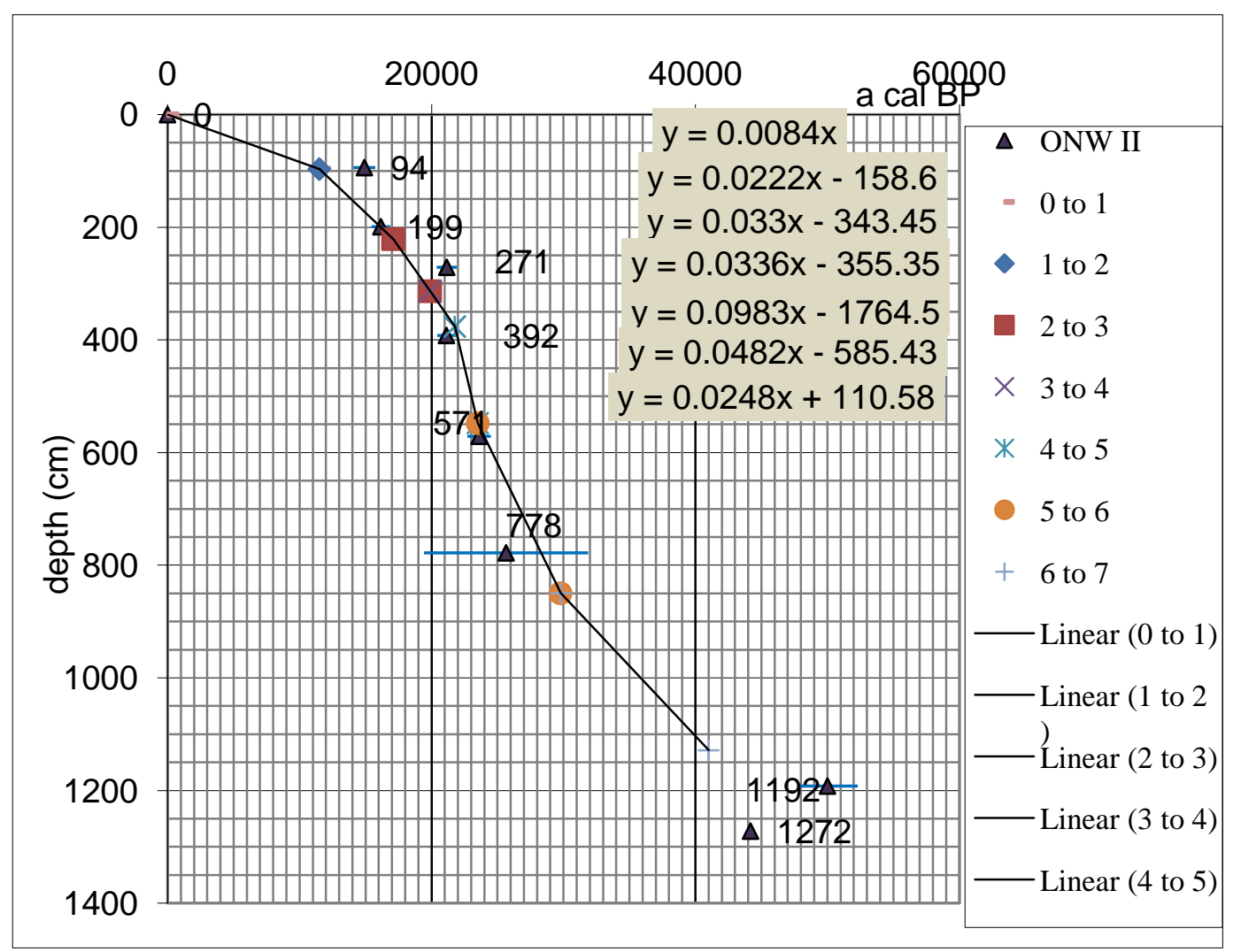

Fig. 4. 3. Age-depth model of lake Orog Nuur.

\subsubsection{Zone ONW $1(1333$ - $1222 \mathrm{~cm}, 49.5$ - 44.7 ka cal BP): semi humid Artemisia steppe}

High Artemisia $(71 \%)$ and minimum Chenopodiaceae $(9 \%)$ pollen percentages are recorded during this zone. Artemisia/Chenopodiaceae ratios (A/C ratios) are around 8 . The pollen proportion of Poaceae (3\%), Brassicaceae (3\%), Caryophyllaceae (2\%) and Thalictrum (1\%) are found relatively high. Arboreal pollen such as the Hippophä̈-type, Picea and Quercus occurs in frequencies up to $2 \%$. The pollen of Liguliflorae and Apiaceae constitute (1-2\%). The Sporormiella-type spores exist with low percentage value, lower than $1 \%$.

The pollen data indicate that the landscape was covered by Artemisia steppe, suggesting sub desert and warm conditions. The relative high frequency of the aforesaid herbaceous taxa shows that these species have grown along the springs near the lake. Heliophilous shrubs or small trees of Hippophaë have grown at some favourable habitats of the landscape beside the temporal rivers (Hilbig, 1995; Grubov, 2001). The increase of Quercus and Picea at the beginning of the zone suggests the transport of these pollen from Mongolian Altai (northwestern Mongolia) through westerlies or denote a short precipitation spell near the Orog Nuur lake. The pollen of grazing weeds like Liguliflorae and 
Apiaceae (1\%) and spores of coprophilous ascomycetes such as the Sporormiella-type (Van Geel et al., 2003) infer to the existence of wild herds.

\subsubsection{Zone ONW $2(1222-1133 \mathrm{~cm}, 44.7$ - 41.2 ka cal BP): semi arid Artemisia steppe}

Artemisia (57\%) still dominates the pollen assemblages. Chenopodiaceae is found in small amounts (14\%) and $\mathrm{A} / \mathrm{C}$ ratios are about 4 . The frequency of Ephedra (up to 5\%) is slightly higher in the upper samples of the core. Liguliflorae (4\%) and the Matricaria-type (8\%) pollen increase. Pollen influx values are very low. The frequency of herbaceous pollen such as Poaceae (4\%), Brassicaceae (2\%) and Caryophyllaceae (2\%) remains similar as in the previous zone. Pollen clumps (2\%) generally increase while Artemisia pollen clumps alone indicate marked peaks up to $11 \%$. The frequency of fungal spores (the Glomus-, Delitschia- and Sporormiella-type) and the concentration of the green algae Botryococcus and Pediastrum slightly increase. The concentration of charcoal increases at the end of the zone.

The decrease of $\mathrm{A} / \mathrm{C}$ ratios compared to previous zone suggests a marked decrease of moisture. Artemisia with a relative gain of Ephedra shrubs reflects desert steppe vegetation (Herzschuh et al., 2006a; Zhao et al., 2007). The high values of the insect transported Matricaria-type suggests that the water level was low with Asteraceae growing near the drilling site. The pollen concentration decreased under semi desert climatic conditions. Poaceae and Caryophyllaceae fluctuate regularly with clear maxima, suggesting climatic instability. This is consistent with the existence of pollen clumps that reveals a strong disturbance of the vegetation as a result of climatic variation (dry/cold events) or shortening of the growing season and /or grazing impact (Schlütz and Lehmkuhl, 2007). The low values of Pediastrum and Botryococcus suggests low lake levels (Jiang et al., 2006; Medeanic and Correa, 2010; Zhao et al., 2007) and a cooler climate (Kramer et al., 2010; Jankovska'and Koma'rek, 2000). The high input of Glomus in the upper samples of the zone reveals soil erosion under dry conditions and supports the notion of thin vegetation cover that is certified by the high concentrations of charcoal (fires). Owing to extreme environment, grazing indicating pollen (Liguliflorae) and fungal spores (the Delitschia- and Sporormiella-type) further expose the pressure of wild herbivores on vegetation in the catchment area of the lake. The presence of grazing indicating pollen and fungal spores might give the strength to the suggestion of Komatsu et al. (2001) about the initial human entry into the area prior to 40,000 years ago and possibly as early as the last interglacial (ca. 125,000 B.P.).

\subsubsection{Zone ONW $3(1133-515 \mathrm{~cm}, 41.2$ - 23.2 ka cal BP): semi humid Artemisia steppe}

Artemisia shows its highest values exceeding up to $85 \%$. Chenopodiaceae is about $12 \%$ and the resulting $\mathrm{A} / \mathrm{C}$ ratios spans to 7 . The frequency of herbaceous pollen shows a little change to the values of the previous zones. Tree pollen such as Nitraria, Salix, the Hippophä̈- and Pinus Haploxylon-type occur in low frequencies $(<1 \%)$. The concentration of Pediastrum and Botryococcus oscillate regularly with well marked maxima. Smut fungi such as the Thecaphora-type (2\%) and mycorrhizal fungus like 


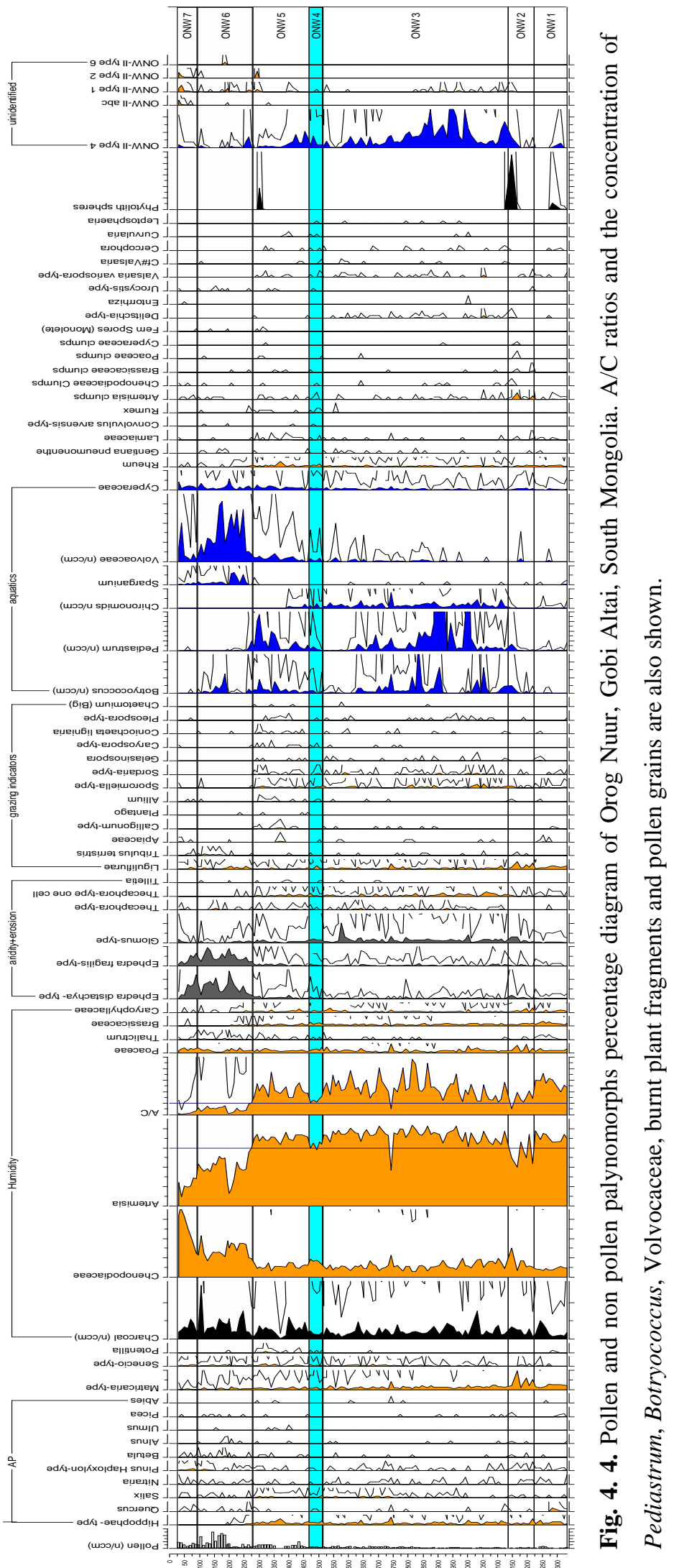


the Glomus-type (3\%) attain highest frequencies. The ascospores of coprophilous fungi such as Gelasinospora, Sordaria-, Pleospora-, Delitschia- and the Sporormiella-type appear with slightly higher values (1\%). The mandibles of Chironomids have their maximal frequency (3\%).

The dominance of Artemisia with a smaller representation of herbaceous pollen led to the establishment of steppe vegetation, reflecting sub desert but cold conditions in the research area. Increase in $\mathrm{A} / \mathrm{C}$ ratios point to an increase of moisture conditions. Arboreal plants like Nitraria might have grown on sandy wet areas near the lake whereas the Salix, and Hippophaë along the banks of temporal rivers (Hilbig, 1995; Grubov, 2001). Pine pollen seems to transport from the nearby Khangai mountains. The highest input of Pediastrum attests high lake levels (Jiang et al., 2006; Kramer et al., 2010; Medeanic and Correa, 2010; Zhao et al., 2007). The sporadic presence of Botryococcus reveals cold lake conditions (Jankovska' and Koma'rek, 2000). The relative high values of the Thecaphoraand Glomus-type suggest soil erosion in sub desert conditions. The increase in coprophilous spores especially the Sporormiella-type is an indication of dung produced by herbivores (Cugny et al., 2010). The maxima of Chironomids mandibles designate that enough food (aquatic plants) was available for herbivores.

\subsubsection{Zone ONW $4(515$ - $469 \mathrm{~cm}, 23.2$ - 22.7 ka cal BP): semi arid Artemisia steppe}

Artemisia pollen (63\%) decreases compared to previous zone but still dominates while Chenopodiaceae (16\%) increase slightly. The A/C ratios drop to 4 . Poaceae (4\%), Brassicaceae (3\%) and Caryophyllaceae (2\%) pollen are comparatively high. The Hippophaë-type pollen shows maximum values (3\%). The concentration of Pediastrum and Botryococcus is very low. The fungal spore Glomus-type is showing the same values as in zone ONW 3.

The comparative low A/C ratios suggest decrease in climate humidity. The pollen data imply Artemisia steppe with dry and warm conditions. The herbaceous pollen might have grown at high altitude with better growing conditions. Hippophaë shrubs have grown beside the lake. The lake level seems to be low reflected by the extremely low values of green algae.

\subsubsection{Zone ONW 5 (469 - $280 \mathrm{~cm}, 22.7$ - 18.9 ka cal BP): semi humid Artemisia steppe}

This zone contains a high proportion of Artemisia pollen (70\%) compared to zone ONW 4. Chenopodiaceae occurs at values of around $12 \%$ and $\mathrm{A} / \mathrm{C}$ ratios are about 6 . The frequency of the Hippophäe-type (3\%) is similar to the pervious zone. A slight increase has been observed in Pediastrum, Botryococcus and Volvocaceae. Grazing indicator pollen and spores are present with low frequency (usually <1\%) and include Liguliflorae, Apiaceae, Plantago, Allium, the Calligonum- and Potentilla-type as well as Coniochaeta ligniaria, the Pleospora- and the Caryospora-type.

The high $\mathrm{A} / \mathrm{C}$ ratios indicate steppe vegetation with relative humid climatic conditions. The comparative high precipitation supported the growth of Hippophä shrubs. The relative increase of the green algae such as Pediastrum (high water level) and Botryococcus confirms (cold) moderate cool 
climate while Volvocaceae attest eutrophic to mesotophic lake conditions (Kramer et al., 2010) and high organic productivity due to stronger input of nutrients to the lake. This input of nutrients might be enhanced by herbivore animals as reflected by the existence of grazing indicating pollen and spores.

\subsubsection{Zone ONW $6(280-92 \mathrm{~cm}, 18.9$ - $11.0 \mathrm{ka}$ cal BP $)$ : relative dry Artemisia desert-steppe}

Pollen of Artemisia (38\%) declines and Chenopodiaceae (29\%) attains a higher frequency in this zone. The A/C ratios decrease to values of $\sim 1$ whereas the Ephedra distachya- (13\%) and Ephedra fragilis-type (10\%) increase. Pollen concentration is high. Arboreal pollen such as Quercus, Alnus and Betula occur occasionally. The frequency of grazing indicating pollen and spores like Liguliflorae and Thecaphora-type, respectively, is comparatively high. Tribulus terrestris appear with its highest frequency in the upper samples of the zone. Sparganium with its local maxima (4\%) appear for the first time. Volvocaceae attains highest concentration. The spores of green algae such as Pediastrum and Botryococcus almost disappear.

The low A/C ratios and highest Ephedra values point probably a mixed patches of Artemisia desert-steppe and Chenopodiaceae desert with Ephedra shrubs. These features may illustrate the onset of drier and colder conditions in the study area. High Chenopodiaceae and high pollen concentration reflect regional vegetation cover around the lake and attest extreme climatic conditions (Grubov, 2001; Shen et al., 2005; Chen et al., 2006). The sporadic occurrence of Quercus, Alnus and Betula contemplate that these pollen transported with westerlies from the high mountain ranges of northwestern Mongolia as a result of strong pressure gradient. Tribulus terrestris, Liguliflorae and the Thecaphora-type are indicative of herbivores. The appearance of Sparganium might indicate that the core site is near the lake shore and lake desiccation is observed (Jiang et al., 2007) on the onset of last glacial period. The highest concentration of Volvocaceae and lowest concentration of Pediastrum and Botryococcus might indicate lake water alkalinity. Pediastrum and Botryococcus prefer an environment with low pH values and acidic water bodies (Kramer et al., 2010; Hermann, 2010). Low $\mathrm{pH}$ can be obtained when concentrations of free carbon dioxide are relatively high. High concentrations of $\mathrm{CO}_{2}$ occur in cold water bodies and at low photosynthetic activity (Kramer et al., 2010). It is assumed that Pediastrum and Botryococcus could not survive any more in high $\mathrm{pH}$ of lake water, might be conducive for Volvocaceae.

\subsubsection{Zone ONW 7 (92 $-25 \mathrm{~cm}, 11.0$ - 3.0 ka cal BP): Arid Chenopodiaceae desert}

Chenopodiaceae attains maximum values of the record (50\%) whereas Artemisia has minimum values (22\%). The A/C ratio declines to $<1$. The frequency of Ephedra pollen (18\%) is as high as in the previous zone. Arboreal pollen like the Pinus Haploxylon-type occurs in low proportion (1\%) while the Hippophäe-type pollen is missing. Poaceae (4\%) pollen increases while the pollen

proportion of Sparganium and the concentration of Volvocaceae decrease. Pediastrum and Botryococcus are completely missing. 
The low A/C ratios denote a saline Chenopodiaceae desert (Cour et al., 1999) with Ephedra shrubs growing in the rock cleavages after the soil cover was eroded (Schlütz and Lehmkuhl, 2007) This points to very extreme (arid) environment than the previous zone. The low proportion of the Pinus Haploxylon-type (1\%) might indicate cooling phase or transported from the Khangai mountains due to low vegetation cover. The relative high value of Poaceae with the low pollen proportion of the aquatic plant Sparganium indicates shallow water and the lake level was near the core site to support the regional abundance of the grasses and aquatic flora. Low concentration of Volvocaceae determines low input of nutrients to the lake and thus low lake productivity in a very dry climate (Kramer et al., 2010). Owing to very arid (low A/C ratio) and cold (high Ephedra shrubs values) conditions, Hippophaë-type pollen, the green algae Pediastrum and Botryococcus disappear and do not exist anymore.

\section{Discussion}

The pollen analyses from the sediments of Orog Nuur interpret vegetation and climate variations during the late Quaternary from southwestern Mongolia (Tab. 4. 2). Artemisia and Chenopodiaceae are the major plants of steppe, semi-desert, and desert vegetation of Mongolia (Hilbig, 1995; Gunin et al., 1999; Fowell et al., 2003). El-Moslimany (1990) applied the A/C ratio to arid and semi arid areas of Asia in order to distinguish steppe and desert vegetation based on pollen analyses and used it as a moisture indicator. This approach is based on the observation that higher Chenopodiaceae percentages characterize desert plants, indicating pronounced aridity, while higher Artemisia percentages point to steppe vegetation (Herzschuh et al., 2006a). It was reported that $\mathrm{A} / \mathrm{C}$ ratios of $<0.5,0.5$ to 1 and $>1$ represent a typical desert community, steppe-desert and typical steppe vegetation respectively (Zhao et al., 2007) in the arid and semi arid regions of China. Cour et al. (1999) identified that the saline desert (western Taklimakan), montane desert (Kunlun), and montane steppe or sub-desert (Karakorum) were respectively represented by $\mathrm{A} / \mathrm{C}$ ratio of $<1,1$ to 2 and $>2$. Our fossil pollen analyses have also shown a significant potential of using A/C ratios during the last $56 \mathrm{ka}$ cal BP. The late Quaternary pollen record of Orog Nuur has been used to infer the vegetation and climate changes of the last $56 \mathrm{k}$ BP.

The results of the initial pollen zone ONW 1 (49.5 - $44.7 \mathrm{ka}$ cal BP) indicate steppe vegetation and suggest semi humid and warm climate. Sun et al. (1997) also implied warm-temperate and sub humid climate between 54.5 to $46.2 \mathrm{ka}$ cal BP from loess plateau in China.

The humid phase is followed by relatively short climate deterioration of semi desert and cool conditions (ONW 2). Similar mirror image of cool conditions has presented by Swann et al. (2005) from 43.2 untill 39 ka BP from lake Baikal, south east Siberia based on diatoms and geochemical analyses. 


\begin{tabular}{|c|c|c|c|c|}
\hline $\begin{array}{c}\text { ONW } \\
\text { zones }\end{array}$ & $\begin{array}{l}\text { Time period } \\
\text { (Ka cal. } \\
\text { B.P.) }\end{array}$ & Vegetation derivations & Climate & $\begin{array}{l}\text { Duration } \\
\text { (ka) }\end{array}$ \\
\hline 7 & $11.0-3.0$ & $\begin{array}{l}\text { Ephedra shrub dominated } \\
\text { Chenopodiaceae desert }\end{array}$ & (cold-)arid & 8.0 \\
\hline 6 & $18.90-11.0$ & $\begin{array}{l}\text { Ephedra shrub dominated } \\
\text { Chenopodiaceae desert }\end{array}$ & $\begin{array}{l}\text { semi-arid } \\
\text { (cold) }\end{array}$ & 7.9 \\
\hline 5 & $22.70-18.90$ & $\begin{array}{l}\text { Artemisia desert-steppe with Pediastrum } \\
\text { and Botryococcus }\end{array}$ & $\begin{array}{l}\text { semi-humid } \\
\quad(\text { cool })\end{array}$ & 3.80 \\
\hline 4 & $23.20-22.70$ & Artemisia desert-steppe & $\begin{array}{l}\text { semi-arid } \\
\text { (warm) }\end{array}$ & 0.50 \\
\hline 3 & $41.25-23.20$ & $\begin{array}{l}\text { Artemisia desert-steppe with green algae } \\
\text { Pediastrum and Botryococcus, erosion } \\
\text { high }\end{array}$ & $\begin{array}{l}\text { semi-humid } \\
\text { (cold) }\end{array}$ & 18.05 \\
\hline 2 & $44.70-41.25$ & $\begin{array}{l}\text { Artemisia desert-steppe with Ephedra } \\
\text { shrubs, Glomus-type, erosion }\end{array}$ & semi-arid (cool) & 3.45 \\
\hline 1 & $49.50-44.70$ & Artemisia desert-steppe & $\begin{array}{l}\text { semi-humid } \\
\text { (warm) }\end{array}$ & 4.8 \\
\hline
\end{tabular}

Tab. 4. 2. Synopsis of vegetation and climate evolution at Orog Nuur, valley of Gobi lakes, South Mongolia.

A change from semi desert to sub humid climatic conditions is observed between 41.2 to $23.2 \mathrm{ka}$ cal BP (zone ONW 3). Such vegetation change represents a signal of semi humid and cold climatic conditions. This is consistent with the findings from palaeoenvironmental records of lake Baikal, western China and western Mongolia (Chen and Bowler, 1986; Liu, 1991; Lehmkuhl and Haselein, 2000). Most of the high lake level periods in lake basins of Mongolia and northwestern China have been dated to the interstadial of last glaciation (Marine oxygen isotope stage 3; MIS 3) at about 40-30 ka (Lehmkuhl and Lang, 2001). Hövermann and Süssenberger, (1986) used the term "Anaglacial” for the beginning of the last glacial cycle, characterized by wet and cold conditions. Chen and Bowler, (1986) inferred lake expansion between $~ 40$ to $25 \mathrm{ka}$ from the lacustrine sediments of Qaidam Basin, northern Tibet. Liu (1991) recognized freshwater conditions and humid climate between 38.6 to 28.7 ka from Qarhan salt lake, Qaidam Basin, China. Lehmkuhl and Haselein (2000) reported humid and cold conditions between 32-24 ka cal BP from western China and western Mongolia. Humid climate is recorded between 40 and $23 \mathrm{ka}$ by Yang et al. (2004). Pachur et al. (1995) recorded humid/cool conditions from $\sim 39$ to $23{ }^{14} \mathrm{C}$ ka, followed by drier conditions, on the basis of palaeoshore-lines and the geochemistry of Ostracoda in lacustrine sediments in the Tengger Desert, north of the Qilian Mountains where as Owen et al. (1997) suggested similar humid conditions between 40 to $23 \mathrm{ka}$ based on observation of alluvial fans in the Gobi desert, Mongolia and correlated the drying trend in central China to changes in sedimentalogical analyses in alluvial fans in the Gobi -Altai.

The time period from 23.2 to $22.7 \mathrm{ka} \mathrm{BP}$ is characterized by warm and dry conditions. Lehmkuhl and Haselein (2000) characterize it as warm period with the initiation of glacier retreat of Qaidam lake, 
China and called it the early stage of the so called "Kataglacial" (24-15 ka cf. Hövermann and Süssenberger, 1986, quoted from Lehmkuhl and Haselein, 2000). This is also consistent with the findings of Chen and Bowler (1986) that reported the warm and dry period between 24 and $21 \mathrm{ka}$ and called this as stage of evaporation. The slight difference in age period might be due to the regional differences in humidity for the dry lands in western China and Mongolia (Yang et al., 2004).

The warm and dry conditions were followed by semi humid and cool conditions between 22.7$18.9 \mathrm{~K}$ cal B.P. Wang et al. (1990) reported high water levels between 22 to $18.5 \mathrm{ka}$ due to high precipitation from different lakes of western Tibet. Fang (1991) suggested the existence of high water level around $18 \mathrm{ka}$ is a subject of special discussion (Lehmkuhl and Haselein, 2000).

In general, dry and cold climate prevailed after 18.9 ka cal B.P. (Fig. 4). The conditions remained arid and cold during the late Pleistocene (18.9-11.0 ka cal BP), becoming hyperarid after 11.0 ka cal B.P in our findings. Similar dry and cold (Chen et al., 1997; Johnsen et al., 2001; Yang et al., 2004) conditions were reported from different parts of monsoonal central Asia. This corresponds to Heinrich 1 event recorded from North Atlantic region (Bond et al., 1992). This interval is supported by the results of Quaternary palaeoenvironmental changes on the Tibetan plateau and adjacent areas (western China and Mongolia by Lehmkuhl and Haselein (2000) while Kramer et al. (2010) inferred similar dry interval between 17.7- $11.5 \mathrm{ka}$ cal B.P. from Naleng lake, Tibetan plateau, China. They reconstructed hyperarid climatic conditions of the evaporate stage between 15 to $9 \mathrm{ka}$. . Based on multi proxy study of sediments, Shen et al. (2005) attest arid and cold climate from 18.2 and 14.1 ka cal B.P from Qinghai lake area, China whereas Hövermann and Süssenberger (1986) reported a dry and cold interval between 14 to $10 \mathrm{ka}$.

It is generally accepted that the Marine Oxygen Isotope Stage 2 (MIS 2) including the last glacial maximum (LGM) was dry and cold in unglaciated areas of Siberia and central China (Komatsu et al., 2001).

The most dry and severe cold interval was recorded between 11.0 to 3.0.ka cal BP. in our lake archive. The palaeoenvironmental reconstruction derived from the Juyanze palaeolake also suggest desert vegetation, low lake levels and dry conditions of the Alashan Plateau, China during early midHolocene (10,700-5400 cal yr BP, Herzschuh et al., 2006b). The pollen record from Lop Nuer in eastern Tarim Basin of western China suggests a desert environment for the entire Holocene (Yang et al., 2004).

\section{Conclusion}

The palynological study from the sediments of Orog Nuur reveals the first high resolution lake archive from the valley of lakes, southwestern Mongolia. The region is located on the margin of summer monsoon and westerlies. The results of this investigation show reconstructed vegetation and climate history during late Quaternary. We conclude that the Orog Nuur located at the Gobi-Altai transition, is highly sensitive to climate and landscape change. 
Our findings emphasize the need of further detailed studies of well selected lake archives of the climatically sensitive area of Mongolia to reconstruct its complex spatial climatic pattern currently controlled by the combined influence of westerlies and the monsoon system (Yang et al., 2004).

Generally warm (interstadial) and semi humid conditions prevailed between 49.5 and $44.7 \mathrm{ka}$ cal BP., correlating to Marine Oxygen Isotope stage 3 (Lehmkuhl and Haselein, 2000). It is followed by relatively dry and cool climate from 44.7 to $23.2 \mathrm{ka}$ cal BP corresponding to Marine Oxygen Isotope stage 2. Increase in temperature with semi arid conditions was observed between 23.2 and $22.7 \mathrm{ka} \mathrm{cal}$ $\mathrm{BP}$, indicating the initiation of glacier retreat during the late glacial times. The aridity of the climate becomes more arid from $22.7 \mathrm{ka}$ cal BP till the late Holocene. Xeromorphic taxa increased in abundance at about $18.9 \mathrm{ka}$ cal BP, indicating that the conditions became arid and cold. The further decrease in precipitation and changes in the vegetation towards desert are reflected by the increase in the frequency of Chenopodiaceae and Ephedra shrubs from about $11 \mathrm{ka}$ cal BP to point hyperarid climatic conditions. More high resolution palaeovegetation and palaeoclimate data is needed to observe short lived events.

\section{Acknowledgments}

This research work is a contribution to the project "Late Pleistocene, Holocene and ongoing geomorph dynamics in the Gobi Desert; South Mongolia" (LE 730/16-1). The authors acknowledge the German science foundation (Deutsche Forschungsgemeinschaft, DFG). We wish to thank Higher Education Commission (HEC), Pakistan, Kohat University of Science and Technology (KUST), Pakistan for financial support for palynological analyses and radiocarbon dating. We sincerely thank the Mongolian Academy of Sciences (Prof. D. Dorjgotov, A. Tschimegsaichan and Serd-Yanjiv Narangerel) for support in the field work.

\section{References}

Academy of sciences of Mongolia and Academy of sciences of USSR., 1990. National Atlas of the people's republic of Mongolia. Ulaan Baatar: Moscow.

Ariunsuren, P., Damiran, D., Stevens, P., 2009. Results of assessment of the current status of degree of disturbance of the desert-steppe rangelands of western Mongolia. In: Proc. Soils and Crops conference. Saskatoon, SK: Canada.

Batjargal, Z., 1997. Desertification in Mongolia. Proceedings of an international workshop on range land desertification. Agricultural Research Institute. RALA Report No. 200.

Bedunah, D.J., McArthur, E.D., Fernandez, G., Maria, C., 2006. Rangelands of Central Asia: Proceedings of the conference on transformations, issues and future challenges; Salt lake city, UT. Proceeding RMRS-P-39.Fort Collins, CO: U.S. Department of Agriculture, Forest Service, Rocky Mountain Research Station. 
Beug, H.J., 2004. Leitfaden der Pollenbestimmung für Mitteleuropa und angrenzende Gebiete, Pfeil Verlag, München.

Bond, G., Heinrich, H., Broecker, W., Labeyrie, L., McManus, J., Andrews, J., Huon, S., Jantschik, R., Clasen, S., Simet, C., Tedesco, K., Klas, M., Bonani, G., Ivy, S., 1992. Evidence for massive discharge of icebergs into the North Atlantic Ocean during the last glacial period. Nature 360, 245-249.

Chen, K., Bowler, J.M., 1986. Late Pleistocene evolution of salt lakes in the Qaidam Basin. Qinghai Province, China. Palaeogeography, Palaeoclimatology, Palaeoecology 54, 87-104.

Chen, F., Bloemendal, J., Wang, J., Oldfield, F., 1997. High-resolution multi-proxy climate records from Chinese loess: evidence for rapid climatic changes over the last $75 \mathrm{kyr}$. Palaeogeography, Palaeoclimatology, Palaeoecology 130, 323-335.

Chen, F.H., Chen, B., Zhao, Y., Zhu, Y., Madson, D., 2006. Holocene environmental change inferred from high resolution pollen records, Lake Zhuyeze, arid China. Holocene 16, 675-684.

Chen, F., Yu, Z., Yang, M., Ito, E., Wang, S., Madsen, D., Haung, X., Zhao, Y., Sato, T., Birks, H., Boomer, I., Chen, J., An, C., Wunnemann, B., 2008. Holocene moisture evolution in arid central Asia and its out-of-phase relationship with Asian monsoon history. Quaternary Science Reviews 27, 351-364.

Cour, P., Zheng, Z., Duzer, D., Calleja, M., Yao, Z., 1999. Vegetational and climatic significance of modern pollen rain in north western Tibet. Review of Palaeobotany and Palynology 104, 183204.

Cugney, C., Mazier, F., Galop, D., 2010. Modern and fossil non-pollen palynomorphs from the Basque mountains (western Pyrenees, France): the use of coprophilous fungi to reconstruct pastoral activity. Vegetation History and Archaeobotany 19, 391-408.

Dgebuadze, Y., 1995. The land/inland-water ecotones and fish population of lake Valley (West Mongolia). Hydrobiologia 303, 235-245.

Dulamsuren, C., Hauck, M., Mühlenberg, M., 2005. Ground vegetation in the Mongolian taiga foreststeppe ecotone does not offer evidence for the human origin of grasslands. Applied Vegetation Science 8, 149-154.

Dulamsuren, C., Hauck, M., Leuschner, C., 2010. Recent drought stress leads to growth reductions in Larix sibirica in the western Khentey, Mongolia. Global Change Biology16, 3024-3035.

El-Moslimany, A.P., 1990. Ecological significance of common non arboreal pollen: Examples from dry lands of the Middle East. Review of Palaeobotany and Palynology 64, 343-350.

Erdtman, G., 1960. The acetolysis method. Svensk Botanisk Tidskrift 54, 561-564.

Fang, J.Q., 1991. Lake evolution during the past 30,000 years in China and its implications for environmental change. Quaternary Research 36, 27-60. 
Feng, Z., Zhai, X., Ma, Y., Huang, C., Wang, W., Zhang, H., Khosbayar, P., Narantsetseg, T., Liu, K., Rutter, N., 2007. Eolian environmental changes in the northern Mongolian plateau during the past 35,000 years. Palaeogeography, Palaeoclimatology, Palaeoecology 245, 505-517.

Fowell, S.J.B., Hansen, C.S., Peck, J.A., Khosbayar, P., Ganbold, E., 2003. Mid to late Holocene climate evolution of the lake Telmen Basin, north central Mongolia based on palynological data. Quaternary Research 59, 353-363.

Grubov, V., 2001. Key to the vascular plants of Mongolia. Vol. 1+2. Science publication, Enfield.

Grunert, J., Lehmkuhl, F., Walther, M., 2000. Paleo-climatic evolution of the Uvs Nuur Basin and adjacent areas (western Mongolia). Quaternary International 65-66, 171-192.

Gunin, P.D., Vostokova, E.A., Dorofeyuk, N.I., Tarasov, P.E., Black, C.C., 1999. Vegetation dynamics of Mongolia. Geobotany 26, 233-238.

Hermann, M., 2010. Palaeoecological reconstruction of the late Oligocene Maar lake of Enspel, Germany using lacustrine organic walled algae. Palaeobiology and Palaeoenvironments 90, 29-37.

Herzschuh, U., Zhang, C., Mischke, S., Herzschuh, R., Mohammadi, F., Mingram, B., Kürschner, H., Riedel, F., 2005. A late Quaternary lake record from the Quilian Mountains (NW China): evolution of the primary production and the water depth reconstructed from macrofossil, pollen, biomarker, and isotope data. Global and Planetary Change 46, 361-379.

Herzschuh, U., Winter, K., Wunnemann, B., Li, S., 2006a. A general cooling trend on the central Tibetan plateau throughout the Holocene recorded by the lake Zigetang pollen spectra. Quaternary International 154-155,113-121.

Herzschuh, U., Kurschner, H., Mischke, S., 2006b. Temperature variability and vertical belt shifts during the last $50000 \mathrm{yr}$ in the Qilian Mountains (NE margin of the Tibetan Plateau), China. Quaternary Research 66,133-146.

Herzschuh, U., 2006. Palaeo-moisture evolution in monsoonal central Asia during the last 50,000 years. Quaternary Science Reviews 25,163-178.

Hilbig, W., 1995. The vegetation of Mongolia. SPB Academic Publishing, Amsterdam.

Hövermann, J., Süssenberger, H., 1986. Zur Klimageschichte Hochund Ostasiens. Berliner Geogr. Studien 20, 173-186.

Jankovska, V., Koma'rek, J., 2000. Indicative value of Pediastrum and other coccal green algae in palaeoecology. Folia Geobotanica 35, 59-82.

Jiang, W.Y., Guo, Z.T., Sun, X.J., Wu, H.B., Chu, G.Q., Yuan, B.Y., Hattée, C., Guiot, J., 2006. Reconstruction of climate and vegetation changes of lake Bayanchagan (Inner Mongolia): Holocene variability of the East Asian monsoon. Quaternary Research 65, 411-420.

Jiang, Q., Shen, J., Liu, X., Zhang, E., Xiao, X. 2007. A high-resolution climatic change since Holocene inferred from multi-proxy of lake sediment in westerly area of China. Chinese Science Bulletin 52, 1970-1979. 
Johnsen, S.J., Dahl-Jensen, D., Gundestrup, N., Steffensen, J.P., Clausen, H.B., Miller, H., MassonDelmotte, V., Sveinbjšrndottir, A.E., White, J., 2001. Oxygen isotope and palaeotemperature records from six Greenland ice-core stations: Camp Century, Dye- 3, GRIP, GISP2, Renland and North GRIP. Journal of Quaternary Science 16, 299-307.

Johnson, D., Sheehy, D., Miller, D., Damiran, D., 2006. Mongolian range lands in transition. Sécheresse 17 (1-2), 133-141.

Juggins, S., 2007. C2 Version 1.5 User Guide. Software for ecological and palaeoecological data analysis and visualization. University of New castle upon Tyne, UK.

Komatsu, G., Brantingham, P., Olsen, J., Baker, V., 2001. Paleoshore line geomorphology of Böön Tsagaan Nuur, Tsagaan Nuur and Orog Nuur: The Valley of Lakes, Mongolia. Geomorphology 39, 83-98.

Kramer, A., Herzschuh, U., Mischeke, S., Zhang, C., 2010. Late Quaternary environmental history of the south-eastern Tibetan plateau inferred from the lake Naleng non-pollen palynomorph record. Vegetation History and Archaeobotany 19, 453-468.

Lehmkuhl, F., Lang, A., 2001. Geomorphological investigations and luminescence dating in the southern part of the Khangay and the valley of the Gobi lakes (central Mongolia). Journal of Quaternary Science 16 (1), 69-87.

Lehmkuhl, F., Haselein, F., 2000. Quaternary Palaeo-environmental change on the Tibetan plateau and adjacent areas (western China and western Mongolia). Quaternary International 65-66, 121145.

Liu, T., 1991. Salt lakes and eolianites in the Qaidam Basin. INQUA 1991 Beijing; Excursion Guide book III.

Ma,Y., Liu, K., Feng, Z., Sang, Y., Wang, W., Sun, A., 2008. A survey of modern pollen and vegetation along a south-north transect in Mongolia. Biogeography 35, 1512-1532.

Medeanic, S., Correa, I., 2010. Climatic changes in the coastal plain of the Rio Grande do Sul state in the Holocene: palynomorphs evidences. Pan-American journal of aquatic sciences 5 (2), 287 297.

Miehe, G., Schlütz, F., Miehe, S., Opgenoorth, L., Cermak, J., Samiya, R., Jäger, E., Wesche, K. 2007. Mountain forest islands and Holocene environmental changes in central Asia: A case study from the southern Gobi Altay, Mongolia. Palaeogeography, Palaeoclimatology, Palaeoecology 250, 150-166.

Moore, P.D., Webb, J.A., Collinson, M.E., 1999. Pollen analysis. Blackwell, Oxford, 2nd. ed.

Onon, Y., Odonchimeg, N., batnasan, N., 2004. Wild life issues in Mongolia. WWF Mongolia program office.

Owen, L.A., Windley, B.F., Cunningham, W.D., Badamgarav, J., Dorjnamjaa, D., 1997. Quaternary alluvial fans in the Gobi of southern Mongolia: evidence for neo tectonics and climate change. Journal of Quaternary Science 12, 239-252. 
Pachur, H.J., Wünnemann, B., Zhang, H., 1995. Lake evolution in the Tengger Desert, Northwestern, during the last 40,000 years. Quaternary Research 44, 171-180.

Peck, J.A., Khosbayar, P., Fowell, S.J., Pearce, R.B., Ariunbileg, S., Hansen, B.C., Soninkhishig, N., 2002. Mid to late Holocene climate change in north central Mongolia as recorded in the sediments of lake Telmen. Palaeogeography, Palaeoclimatology, Palaeoecology 83, 135-153.

Prokopenko, A.A., Khursevich, G.K., Bezrukova, E.V., Kuzmin, M.I., Boes, X., Williams, D.F., Fedenyn, S.A., Kulagina, N.V., Letunova, P., Abzaeva, N., 2007. Paleoenvironmental proxy records from Lake Hovsgol, Mongolia and a synthesis of Holocene climate change in the lake Baikal watershed. Quaternary Research 68, 12-17.

Rudaya, N., Tarasov, P., Dorofeyuk, N., Solovieva, N., Kalugin, I., Andreev, A., Diekmann, B., Riedel, B., Tserendash, N., Wanger, M., 2009. Holocene environments and climate in the Mongolian Altai reconstructed from the Hoton-Nur pollen and diatom records: a step towards better understanding climate dynamics in central Asia. Quaternary Science Reviews 28 (5-6), 540-554.

Schlütz, F., Lehmkuhl, F., 2007. Climatic change in the Russian Altai, southern Siberia based on palynological and geomorphological results with implications for climatic teleconnections and human history since the middle Holocene. Vegetation History and Archaeobotany 16, 101118.

Schlütz, F., Dulamsuren, C., Wieckowska, M., Mühlenberg, M., Hauck, M., 2008. Late Holocene vegetation history suggests natural origin of steppes in the northern Mongolian mountain taiga. Palaeogeography, Palaeoclimatology, Palaeoecology 261, 203-217.

Shen, J., Liu, X., Wang, S., M, Ryo., 2005. Palaeoclimatic changes in the Qinghai lake area during the last 18,000 years. Quaternary International 136, 131-140.

Stuiver, M., Polach, H. A., 1977. Discussion reporting 14C data. Radiocarbon 19, 355-363.

Swann, G.E.A., Mackay, A.W., Leng, M.J., Demory, F., 2005. Climatic change in central Asia during MIS 3/2: a case study using biological responses from lake Baikal. Global and Planetary Change 46, 235-253.

Sun, X., Song, C., Wang, F., Stunt, M., 1997. Vegetation history of the loess plateau of China during the last 100,000 years based on pollen data. Quaternary International 37, 25-36.

Tuvdendorzh, D., Myagmarzhav, B. (eds)., 1985. Atlas of the climate and ground water resources in the Mongolian people's republic. GUGMS, Ulaan Bator.

Van Geel, B., Buurman, J., Brinkkemper, O., Schelvis, J., Aptroot, A., van Reenen, G., Hakbijl, T., 2003. Environmental reconstruction of a roman Period settlement site in Uitgeest (Netherlands) with special reference to coprophilous fungi. Journal of archaeological Science $30,873-883$.

Vanky, K., 1994. European smut fungi.Gustav Fischer Verlag,Stuttgart. New York. 
Vandenberghe, J., Renssen, H., Huissteden, K., Nugteren, G., Konert, M., Lu, H., Dodonov, A., Buylaert, J., 2006. Penetration of Atlantic westerly winds into central and East Asia. Quaternary Science Reviews 25, 2380-2389.

Visbeck, M., 2002. The ocean's role in Atlantic climate variability. Science 297, 2223-2224.

Wang, F., Cao, Q., Liu, F., 1990. The recent changes of lakes and drainage system in the South piedmont of the West Kunlun Mountain, China. Quaternary Sciences 4, 316-325.

Wang, W., Feng, Z., Lee, X., Zhang, H., Ma, Y., An, C., Guo, L. 2004. Holocene abrupt climate shifts recorded in Gun Nuur lake core, northern Mongolia. Chinese Science Bulletin 49, 520-526.

Wang, W., Ma, Y.Z., Feng, Z.D., Meng, H.W., Sang,Y.I., Zhai. X.W. 2009. Vegetation and climate changes during the last $8660 \mathrm{cal}$. a BP in central Mongolia based on a high resolution pollen record from lake Ugii Nuur. Chinese Science Bulletin 54 (9), 1579-1589.

Wang, W., Ma, Y.Z., Feng, Z.D., Narantsetseg, T., Liu, K.B., Zhai, X., 2011. A prolonged dry midHolocene climate revealed by pollen and diatom records from lake Ugii Nuur central Mongolia. Quaternary International 229: 74-83.

Weninger, B., Jöris, O., 2008. A ${ }^{14} \mathrm{C}$ age calibration curve for the last $60 \mathrm{ka}$ : the Greenland-Hulu U/Th timescale and its impact on understanding the middle to upper Paleolithic transition in western Eurasia. Journal of Human Evolution 55, 772-781.

Yang, X., Rost, K.T., Lehmkuhl, F., Zhenda, Z., Dodson, J., 2004. The evolution of dry lands in Northern China and in the republic of Mongolia since the last glacial maximum, Quaternary International 118-119, 69-85.

Zhao, Y., Yu, Z., Chen, F., Ito, E., Zhao, C., 2007. Holocene vegetation and climate history at Hurleg lake in the Qaidam Basin, north west China. Review of Palaeobotany and Palynology 145, $275-288$. 


\section{Chapter 5}

\section{Supplementary Study (unpublished)}

\section{Vegetation and climate history of Olgoy Nuur, central Mongolia during late Glacial to Holocene based on pollen records}

\section{General comments}

This chapter is written in the style of a manuscript but preliminary results are presented here due to the unavalaibility of optically stimulated luminescence (OSL) dating analyses. The samples of the core (Lake archive of Olgoy Nuur) are still under study for OSL dating by Alexendra Hilgers, Institute of Geography, University of Cologne. The abstract, discussion and conclusion about this manuscript will be written after the completion of dating analyses. The sediments of Olgoy Nuur are collected from three different sites rather than a single core. The lower two zones i.e. OLG U (Olgoy bottom) and OLG O (Olgoy top) in pollen diagram (Fig.5.1) indicate the results of two different sites and roughly covers late Glacial age. The difference in time duration between the samples of top and bottom sampling site is currently unknown. The upper two zones (OLG 1a and OLG 1b) are showing the analyses of sediment samples of a third site of Olgoy Nuur (OLG 1) and it roughly determine the transition stage from Pleistocene to early Holocene.

\section{Introduction}

High-resolution pollen records of the sediments are very essential from climatically sensitive regions like Mongolia to understand the vegetation history, climate changes and their controlling mechanisms. Few research studies have been carried out in different parts of Mongolia to reconstruct the climate changes during the transitional period from the late Glacial to Holocene and disputes still remain regarding the vegetation history and climatic stability (Tarasov et al., 1999, 2000; Feng et al., 2007). It is also to be mentioned here that most of the palaeoecological surveys conducted in Mongolia are restricted to the Holocene. Wang et al. (2009) proposed that a mid-Holocene optimum have prevailed in Ugii Nuur, central Mongolia. The same approach of mid Holocene optimum (wet and warm) is also revealed from the pollen, lacustrine and eolian recods from Hoton Nuur (Tarasov et al., 2000) and Gun Nuur (Wang et al., 2004; Feng et al., 2005) northern Mongolia. Contrary to this approach, Peck et al. (2002) and Fowell et al. (2003) reported a dry mid-Holocene climate (7110 and $4390 \mathrm{cal}$ a BP) shown by low lake level and high pollen based aridity index. A dry mid-Holocene climate is also reconstructed by Feng et al. (2005) from Mongolian plateau where as pollen and diatom records from lake Hovsgol documented a warm and dry climate between 6000 and 3500 cal a BP (Prokopenko et al., 2007). Wang et al. (2011) also suggested a prolonged mid-Holocene drought prevailing extensively in the central-east Asian arid and hyper-arid areas based on temperature and climate indices inferred 
from pollen and diatom records of Lake Ugii Nuur, central Mongolia. It is worthy to note here that all these previous studies present asynchrous results. Therefore, more work is needed to assess the stability of Holocene and reconstruct the vegetation history and climate change during the transitional period from the late Glacial to Holocene.

To further improve our understanding of the transitional period from the late Glacial to Holocene, we present a high-resolution pollen record from the Olgoy Nuur (OLG) lake to retrieve the vegetation history variations and associated climate changes during the late Quaternary. The study site seem to be one of the most sensitive areas to climate changes due to its location at the transition zone of dry steppe and forest steppe vegetation. It is expected that the regional reconstruction will be very helpful in overall understanding of climate changes of central Mongolia. It should be noted that our archive would facilitate our understanding of the controlling mechanisms during the transition from the late glacial to the Holocene.

\section{Regional setting}

The Olgoy Nuur lies in the foothill piedmont at the southern flank of the Hangai Mountains in the valley of Gobi lakes. The valley is $500 \mathrm{~km}$ long, $150 \mathrm{~km}$ wide and has an average elevation of 1000 $1400 \mathrm{~m}$. The valley of Gobi lakes is characterized by an extreme continental climate with cold and dry winters. The summers are hot and arid. The mean annual temperature is $2{ }^{\circ} \mathrm{C}$ to $6{ }^{\circ} \mathrm{C}$ but can vary from $-16{ }^{\circ} \mathrm{C}$ in January to $20{ }^{\circ} \mathrm{C}$ in July. The mean annual precipitation is about $250 \mathrm{~mm}$ (Tuvdendorzh and Myagmarzhav, 1985; Finch, 1996).

The modern zonal vegetation around the Olgoy Nuur is dominated by Poaceae (Stipa species, Cleistogenes Squarrosa steppes), Artemisia frigida and Chenopodiaceae. The Poaceae dominated steppe is divided in to dry steppes and humid meadows. The dry steppe includes Stipa species, Kochia prostrate and Salsola ruthenica on sunny and drier slopes. The meadow steppes contain Stipa species and Carex species (Cyperaceae) in lake shore wetlands (Tuvdendorzh and Myagmarzhav, 1985; Hilbig, 1995).

\section{Materials and methods}

Sediment samples of $1-2 \mathrm{~cm}^{3}$ were taken at every $10 \mathrm{~cm}$ interval from the sediment samples of the cores OLG 1 and OLG top where as at $20 \mathrm{~cm}$ interval from core OLG bottom. All the pollen samples were processed in the laboratory using $\mathrm{KOH}, \mathrm{HCl}, \mathrm{HF}$ and acetolysis with standard palynological procedure (Erdtman, 1960; Moore et al., 1999). Two tablets of Lycopodium spores were added to each sample for calculating pollen concentration (pollen grains $/ \mathrm{cm}^{3}$ ), pollen influx (pollen grains $/ \mathrm{cm}^{2} / \mathrm{yr}$ ) and charcoal. The suspensions were sieved in an ultrasonic bath through a $1.5 \mathrm{um}$ mesh and glycerin was used for storage and preparation of microscopic slides.

The preservation was not so good and the palynomorphs percentage was very low to count a total of 400 pollen grains in every sediment sample. In total 19 pollen taxa and 12 spore types were identified 
in the 32 sediment samples. The pollen percentages were calculated on the bases of pollen sum in every sample. The sum of pollen counts was excluding the pollen of Cyperaceae and aquatics, algae and fungal spores. Pollen sum in few samples was high up to 350 pollen. The immature pollen grains sticking together, denoting pollen clumps, were also observed as palaeoecological parameter (Schlütz and Lehmkuhl, 2007). Pollen and spore types were identified with the help of available literature (Beug, 2004; Moore et al., 1999; Van Geel et al., 2003; Vanky, 1994) and on reference collection at the Department of Palynonlogy and Climate Dynamics, Göttingen. The pollen and spores percentage diagram was plotted using the software C2 version 1.5.1 (Juggins, 2007). In diagram, all the taxa are arranged according to their ecology and chronological order.

\section{Results and interpretation}

Four stratigraphical zones are distinguished from bottom to the top based on the variations in percentage values of the palynomorph and associated fungal spores. These zones are labeled as OLG U, OLG O, OLG 1a and OLG 1b (Fig. 5.1). The brief description of the zones is summarized below:

\section{Zone OLG U (5 samples): Artemisia steppe, semi humid and warm conditions}

This zone contains high proportion of Artemisia (51\%) followed by Chenopodiaceae (26\%). The Artemisia / Chenopodiaceae ratios (A/C ratio) are $>2$. The pollen frequency of Poaceae (10\%), Thalictrum (4\%) and Quercus (5\%) are found relatively high. The fungal spore of Sporormiella-type occure in high frequency $(4 \%)$

The high $\mathrm{A} / \mathrm{C}$ ratio of $>2$ and the relative high values of Poaceae and Thalictrum represent the establishment of meadow steppe vegetation and attest better growing (warm and humid) climatic conditions which allow the Quercus trees to grow at some favorable habitats on the landscape. The occurrence of fungal spore such as Sporormiella-type at relative high values point to grazing impact during this zone.

\section{Zone OLG O (5 samples): Forest steppe or meadow steppe, humid and cold conditions}

Both Artemisia (16\%) and Chenopodiaceae (10\%) show a simultaneous decrease while Poaceae (42\%), Cyperaceae (29\%) increase sharply. The A/C ratio is $\sim 1$. Thalictrum pollen remains more or less same as in previous zone. The pollen proportion of Ephedra distachya- (12\%), Ephedra fragilistype (11\%) and Pinus Haploxylon-type (8\%) increase. Pollen concentrations decrease sharply. The concentration of green algae such as Pediastrum (60\%) and Botryococcus (53\%) and fungal spores like Glomus-type (108\%) occur at relatively high values. Dung related fungal spores such as Diporotheca, Podospora- and Sordaria-type attain their highest values. The proportion of smut fungi such as the Thecaphora- and Tilletia-type is also high. The concentration of charcoal has maximal frequency. 


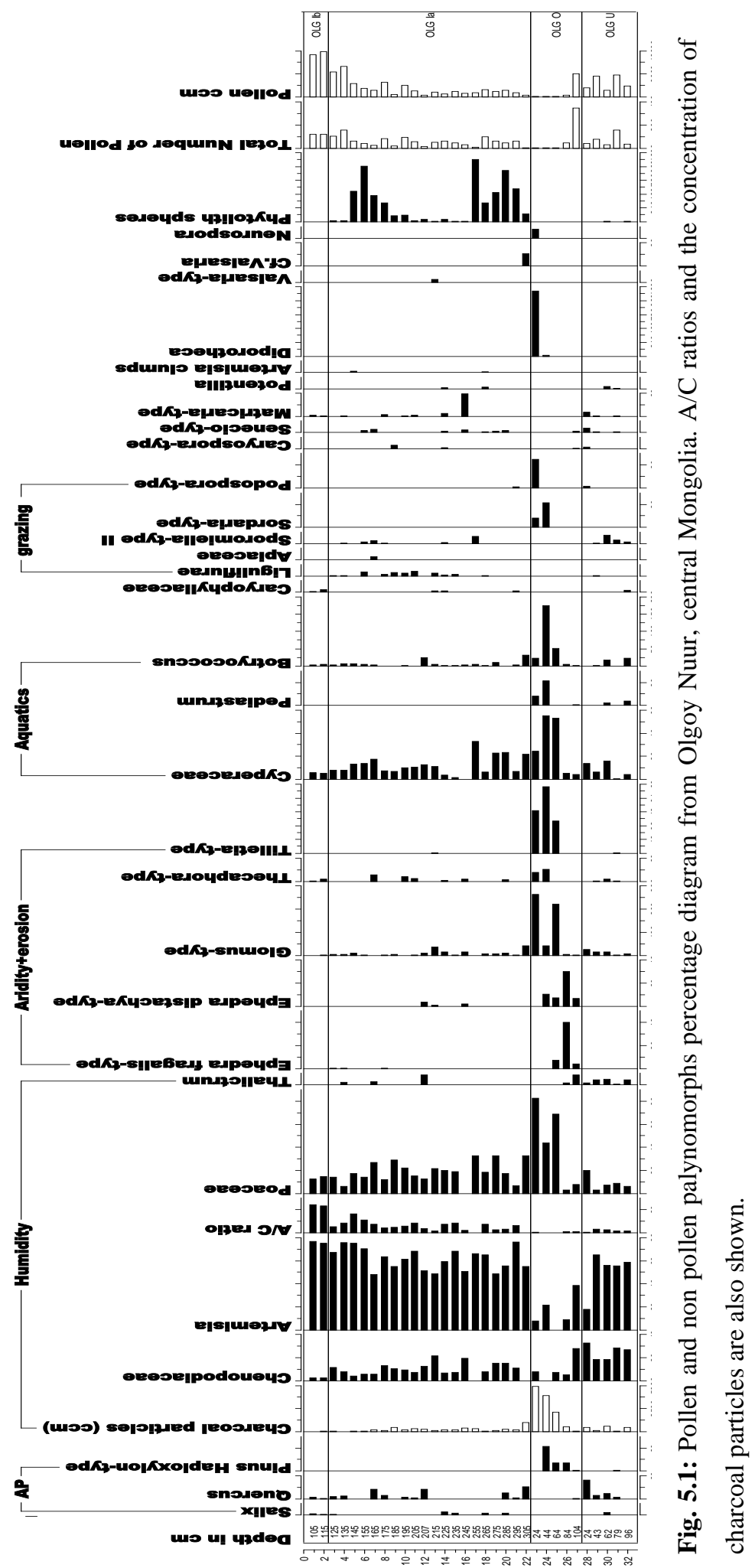


The simultaneous decrease of Chenopodiaceae and Artemisia indicate cold but humid conditions (Jiang et al., 2007). This is consistent to the notable increase in Poaceae, Cyperaceae and the relatively high mean values of Thalictrum, documenting humid forest steppe or meadow steppe around the lake. The highest percentages of Ephedra and Pinus Haploxylon-type imply cold conditions around the study site. The increase of Ephedra shrubs might be due to a strong seasonality of precipitation in response to winter and summer insulation contrast (Zhao et al., 2007). The increase of Pediastrum also shows a humid phase (Zhao et al., 2007; Kramer et al., 2010) whereas Botryococcus is known to tolerate cold conditions (Rull et al., 2008). Owing to winter and summer insulation contrast, extreme cold and high precipitation the pollen production is decreased. The mycorrhizal fungus (Glomus-type) is erosion indicator. Due to soil erosion the minerogen input is expected into the lake due to uneven high precipitation in very cold cold conditions. The view of soil erosion is also supported by the high input of smut fungi such as Thecaphora- and Tilletia-type (Kramer et al., 2010. The relative increase of Diporotheca, Podospora- and Sordaria-type at the end of the zone indicate grazing activities. The contrasting humid and cold conditions led to thin vegetation cover, further affected by severe fires (charcoal).

\section{Zone OLG 1a (20 samples): Artemisia steppe, semi desert and dry conditions}

A significant spike is noted in the frequency of Artemisia (62\%) while Chenopodiaceae (10\%) is as same as in earlier zone, leading to high A/C ratio of $>6$. There is a gradual decrease in Poaceae (19\%) relative to previous zone. Tree pollen such as Quercus (3\%) and Salix (1\%) occurs in low proportion. The frequency of grazing weeds and spores such as Liguliflorae and the fungal spores such as the Sporormiella- and Thecaphora-type may reach up to $2 \%$. The concentration of phytoliths achieves highest values.

The high A/C ratio reflects the establishment of Artemisia steppe and attests relative dry conditions. Quercus and Salix have grown at some favourable sites at water banks under semi desert conditions. Liguliflorae (2\%) and the fungal spores such as Sporormiella-type and Thecaphora-type point to grazing impact.

\section{Zone OLG 1b (2 samples): Artemisia steppe, humid but warm conditions}

Artemisia $(77 \%)$ pollen attains maximum frequency while Chenopodiaceae (3\%) drops to its minimum percentage, leading to very high $\mathrm{A} / \mathrm{C}$ values of 24. Caryophyllaceae, Cyperaceae and Poaceae occur at relative high values. Pollen concentration is very high. The very high $\mathrm{A} / \mathrm{C}$ ratios and the gradual increase in herbaceous pollen document steppe vegetation established during humid and warm conditions. 


\section{Acknowledgments}

The research work is a contribution to the project "Late Pleistocene, Holocene and ongoing geomorpho dynamics in the Gobi Desert., South Mongolia" (LE 730/16-1). The authors acknowledge German Research Foundation (Deutsche Forschungsgemeinschaft, DFG) for financial support. The project is partially funded by Higher Education commission (HEC), Pakistan, Kohat University of Science and Technology, Kohat (KUST), Pakistan for radiocarbon dating and Palynological analysis. We sincerely thank to the Mongolian Academy of Sciences (Prof. D. Dorjgotov, A. Tschimegsaichan and Serd-Yanjiv Narangerel) for extending support during the field work.

\section{References}

Beug, H.J., 2004. Leitfaden der Pollenbestimmung für Mitteleuropa und angrenzende Gebiete, Pfeil Verlag, München.

Erdtman, G., 1960. The acetolysis method. Svensk Botanisk Tidskrift. 54, 561-564.

Feng, Z.D., Wang, W.G., Guo, L.L., Li, X.Q., Ma, Y.Z., Zhang, H.C., An, C.B., 2005. Holocene climate changes in the Mongolian Plateau: preliminary results. Quaternary International 136, 25-32.

Feng, Z., Zhai, X., Ma, Y., Huang, C., Wang, W., Zhang „H., Khosbayar, P., Narantsetseg, T., Liu, K., Rutter, N., 2007. Eolian environmental changes in the Northern Mongolian Plateau during the past 35,000 years. Palaeogeography, Palaeoclimatology, Palaeoecology 245, 505-517.

Finch, C., 1996. Mongolia's wild heritage. Mongolian Ministry for Nature and the Environment. Hong Kong: Avery Press.

Fowell, S.J.B., Hansen, C.S., Peck, J.A., Khosbayar, P., anbold, E., 2003. Mid to late Holocene climate evolution of the Lake Telmen Basin, North Central Mongolia based on palynological data. Quaternary Research 59, 353-363.

Hilbig, W.,1995. The vegetation of Mongolia. SPB Academic Publishing, Amsterdam.

Jiang, Q., Shen, J., Liu, X., Zhang, E., Xiao, X. 2007. A high-resolution climatic change since Holocene inferred from multi-proxy of lake sediment in westerly area of China. Chinese Science Bulletin 52, 1970-1979.

Juggins, S., 2007. C2 version 1.5.1 User Guide. Software for ecological and palaeoecological data analysis and visualization .University of New castle upon Tyne, UK. 
Kramer, A., Herzschuh, U., Mischeke, S., Zhang, C., 2010. Late Quaternary environmental history of the south-eastern Tibetan plateau inferred from the lake Naleng non-pollen palynomorph record. Vegetation History and Archaeobotany 19, 453-468.

Moore, P.D., Webb, J.A., Collinson, M.E., 1999. Pollen analysis. Blackwell, Oxford, 2nd. ed.

Peck, J.A., Khosbayar, P, Fowell, S.J., Pearce, R.B., Ariunbileg, S., Hansen, B.C.S., Soninkhishing, N., 2002. Mid to late Holocene climate change in north central Mongolia as recorded in the sediments of lake Telmen. Palaeogeography, Palaeoclimatology, Palaeoecology 183, 135-153.

Prokopenko, A.A., Khursevich, G.K., Bezrukova, E.V., Kuzmin, M.I., Boes, X., Williams, D.F., Fedenyn, S.A., Kulagina, N.V., Letunova, P., Abzaeva, N., 2007. Paleoenvironmental proxy records from lake Hovsgol, Mongolia, and a synthesis of Holocene climate change in the lake Baikal watershed. Quaternary Research 68, 12-17.

Rull, V., Jose', A. Lo'pez, S., Teresa, V. 2008. Contribution of non-pollen palynomorphs to the paleolimnological study of a high-altitude Andean lake (Laguna Verde Alta, Venezuela). Journal of Paleolimnology 40, 399-411.

Schlütz, F., Lehmkuhl, F., 2007. Climatic change in the Russian Altai, southern Siberia, based on palynological and geomorphological results, with implications for climatic teleconnections and human history since the middle Holocene. Vegetation History and Archaeobotany 16, $101-118$.

Tarasov, P.E., Peyron, O., Guio, J., Brewer, S., Volkova, V.S., Bezusko, L.G., Dorofeyuk, N.I., Kvavadze, E.V., Osipova, I.M., Panova, N.K., 1999. Last Glacial Maximum climate of the former Soviet Union and Mongolia reconstructed from pollen and plant macrofossil data. Climate Dynamics 14, 227-240.

Tarasov, P.E., Volkova, V.S., Webb, T., III, Guiot, J., Andreev, A.A., Bezusko, L.G., Bezusko, T.V., Bykova, G.V., Dorofeyuk, N.I., Kvavadze, E.V., Osipova, I.M., Panova, N.K. and Sevastyanov, D.V., 2000. Last Glacial Maximum biomes reconstructed from pollen and plant macrofossil data from Northern Eurasia. Journal of Biogeography 27, 609-620.

Tuvdendorzh, D., Myagmarzhav, B. (Eds.), 1985. Atlas of the climate and ground water resources in the Mongolian People's Republic. Ulaan Baatar. 
Van Geel, B., Buurman, J., Brinkkemper, O., Schelvis, J., Aptroot, A., van Reenen, G., Hakbijl, T., 2003. Environmental reconstruction of a roman Period settlement site in Uitgeest (Netherlands), with special reference to coprophilous fungi. Journal of archaeological Science $30,873-883$.

Vanky, K., 1994. European smut fungi. Gustav Fischer Verlag, Stuttgart. New York.

Wang, W., Feng, Z., Lee, X., Zhang, H., Ma, Y., An, C., Guo, L. 2004. Holocene abrupt climate shifts recorded in Gun Nuur lake core, northern Mongolia. Chinese Science Bulletin 49, 520-526.

Wang,W., Ma Y.Z., Feng, Z.D., Meng, H.W., Sang,Y. I., Zhai. X.W., 2009. Vegetation and climate changes during the last 8660 cal. a BP in central Mongolia based on a high resolution pollen record from lake Ugii Nuur. Chinese Science Bulletin 54 (9), 1579-1589.

Wang, W., Ma Y.Z., Feng, Z., Narantsetseg, T., Liu, K., Zhai, X., 2010. A prolonged dry midHolocene climate revealed by pollen and diatom records from Lake Ugii Nuur in central Mongolia. Quaternary International ( In press).

Zhao, Y., Yu, Z., Chen, F., Ito, E., Zhao, C., 2007. Holocene vegetation and climate history at Hurleg Lake in the Qaidam Basin, northwest China. Review of Palaeobotany and Palynology 145, 275-288. 


\section{Chapter 6}

\section{Supplementary Studies (Unpublished)}

\section{MASTER KEY FOR POLLEN GRAINS IDENTIFIED FROM BAYAN TOHOMIIN NUUR, OROG NUUR AND OLGOY NUUR, MONGOLIA}

LIST OF TABLES

1

+ Grains with air sacs.

Table I

- Grains without air sacs.....

2

$2+$ Pollen grains with no distinct porus or colpus, some having colpi like grooves (Ephedra).

Table II

- Pollen grains either with porus or colpus or with both.....

\section{3}

+ Porate (sulcate) or colporate pollen grains................ 4

- Colpate pollen grains............................................... Table III

4

+ Colporate pollen grains.

Table IV

- Porate pollen grains................................ 5

$5+$ Monoporate and monosulcate pollen grains......

Table V

- Tri to hexazonoporate and periporate pollen grain.

Table VI

Table I saccate (vesiculate)

$1+$ Pollen bisaccate, large and more than 80 um, angular transition between body and bladder, the wall opposite the bladder is very thick and uneven, proximal part of the exine (crest) more than $5 \mathrm{um}$ in thickness...............

- Pollen bisaccate, less than 80 um in size, proximal part of the exine less than 5 um in thickness.

+ Smooth transition between Bladder and body wall, more than 75 um in size, no clear constriction between air sac and body of the grain.

- Pollen less than 75 um, there is distinct constriction Between air sac and body of the grain.

$3+$ Abrupt transition between structure of air sacs and that of the wall of the body, colpus membrane dotted 
- Smooth transition between structure of air sac and that of the wall of the body, colpus membrane smooth

Pinus Diploxylontype

\section{Table II polyplicate and inaperturate}

$1+$ Grain with meridional groves (Longitudinal ridges) and polyplicate.....

2

- Grain without meridional groves (Longitudinal ridges).

3

$2+$ Groves few (usually 3-8) and branched.

Ephedra distachyatype

- Groves many (usually more than 10) with straight edges and un branched....

Ephedra fragilis-type

$3+$ Grain reticulate, sculpturing elements arranged in a reticulate pattern of muri, lumina variable in size and shape.

- Grain psilate, Gemmate or scabrate.

Potamogeton pictinatus-type 4

+ Grain gemmate, microgemmate or with minute granules or having mixture of all these but not clavate or baculate....

- Grain pear shaped, heteropolar with thin areas (Lacunae), one of the lacunae usually forms a rudimentary pore at broad end.

Cyperaceae

+ Gemmae scattered, deciduous, grains commonly two slits, smaller than 50 um in size

Juniperus

- Grain circular but mostly crumpled or split in the manner of Juniperus, larger than 50 um in size.

Larix

\section{Table III colpate (tricolpate and polycolpate)}

$1+$ Tricolpate pollen grain

2

- Stephanocolpate ( polyzonocolpate) grain

Mentha

$2+$ Grains rugulate-striate or reticulate-rugulate

3

- Grains other than above type............................... 4

$3+$ Distinctly striate grain, striae meridional

Acer- type

- Reticulate-rugulate or eureticulate grains.

Brassicaceae

4

+ Grain clavate (Intectate), clavae free and variable.

Ilex 
- Grains having no clavae...

$5+$ Columellae dimorphic,sparse thick columellae Irregularly arranged among numerous

fine columellae.

- Columellae monomorphic

$6+$ Columellae branched, tectum is perforated and Grains psilate

- Columellae unbranched, grains reticulate, echinate, verrucate or aerolate

+ Grains aerolate, colpus long sunkun with acute ends

- Grains reticulate, echinate or verrucate

8

+ Tectum reticulate with smooth muri, furrows are straight and narrow,some time hexacolpate.

- Tectum verrucate or echinate

9

+ Tectum verrucate

- Tectum echinate,columellae of same length all over the surface and infra reticulate.

10

+ Verrucae rounded, columellae appear as white dots in high focus

- Verrucae elongated and unequally distributed.

Table IV colporate pollen grain

1

+ Grain fenestrate.

- Grains non fenestrate

2

+ Pollen grain hexazonocolporate or polycolporate

- Pollen grain tricolporate.

$3+$ Grain hexazonocolporate, psilate-scabrate-echinate, one porus per colpus, operculum as broad as the intercolpium.

- Grain polycolporate, ectocolpus long narrow with acute ends.

$4+$ Pollen grain psilate, scabrate, echinate or verrucate.

- Pollen grain micro reticulate, striate, striate reticulate,
Ranunculus acristype

6

Convolvolus

7

Myricaria germanica

8

Lamiaceae

9

10

Papaver rhoeas-type

Anemone-type

Quercus

Liguliflorae

2

3

4

Sanguisorba officinalis

Nitraria 5 
striate regulate.

+ Columellae branched, tectum echinate.

- Columellae unbranched, tectum may be echinate, psilate to scabrate-verrucate

+ Tectum echinate or verrucate, membrane rough, true columellae visible under tectum.

- Psilate or scabrate grain....

7

+ Mesocolpium convex, colpi long curving round the margin.

- Mesocolpium without such characteristics.

8

+ Endoaperture is 8 shaped, colpi sunken or enrolled.

- Having no such colpi and endoaperture.

9

+ Tectum densely punctuate, finely scabrate, sexine as thick as nexine

- Psilate or scabrate, rarely rugulate, exine has out thick and inner thin layer, pori oblong, colpus wider in middle and narrow at both ends, the margins of pori are irregular.

+ Grain elliptic, oblate-spheriodal, prolate, sub prolate with costae.

- Grain pea nut shaped with internal thickening (costae) surrounding a porus

11

+ Striate-rugulate.

- Micro reticulate or striate reticulate

12

+ Striate-rugulate exine pattern, branched striae.

- Striate-rugulate, striae without branching.

13

+ Operculate colpi

- Non operculate colpi

14

+ Micro reticulate grain, pori lolongate, sometimes tetra colporate

- Striate reticulate grain.

$15+$ Colpi with acute ends, membrane granular, exine tectate.
10

Senecio-type

6

Matricaria-type

7

Hippophae-type

8

Solanum nigrum-type

9

Rheum-type

Artemisia

11

Apiaceae

12

14

Sorbus-type

13

Potentella-type

Gentiana pneumonenthe-type

Rumex-type

15

Haplophyllum 
- Outline margin micro wavy, having pronounced margo, reticulation (both muri and lumina) decrease in size near the furrow.

Salix

Table V monoporate and monocolpate

$1+$ Grain bilaterally symmetrical, monosulcate (Monocolpate).

Allium-type

- Grain radially symmetrical, porate

2

$2+$ Porus indistinct, without operculum and annulus

3

- Circular porus with a distinct annulus, grain tectate, scabrate, psilate.

Poaceae

$3+$ Grain often crumpled, spinulate-punctate or echinate, porus more or less circular and very small.

Lemna

- Grain surface micro reticulate, tectate perforate.

Sparganium-type

Table VI tri-hexaporate and polyporate

$1+$ Pollen grain tri-hexa zonoporate

2

- Pollen grain periporate................................... 6

$2+$ Trizonoporate, vestibulate pori, vestibular conical with slanting sides than cylindrical ...

Betula

- Tetra-hexazonoporate, echinate or scabrate to regulate...

3

+ Tetra-pentazonoporate, psilate, scabrate to rugulate

4

- Tetra-hexazonoporate, echinate, pori slightly

Protruding and shallow.

Ulmus

$4+$ Scabrate to rugulate pollen, pori with distinctive Lines of thickening (acri) joining the pori in both hemispheres.

Alnus

- Psilate pollen, pori without distinctive lines of thickening (acri)

5

+ Annulus protruding, more thick and distinct

Myriophyllum spicatum-type

- Annulus flattened and indistinct...

Myriophyllum verticellatum-type

6

+ Distinct annulus always present

7 
- Distinct annulus or operculum may or may not be present.............................................. 9

$7+$ Grain with differentiated annulus around porus............ 8

- Pori appear sunken and surrounded by fine, short, regularly arranged columellae forming a diffuse

Allisma-type

8

+ Tectum perforate, reticulate or reticulate scabrate............... Caryophyllaceae

- Tectum non perforate, microechinate.................... Chenopodiaceae

$9+$ Tectum coarsely reticulate (almost having no tectum)

Tribulus terristris

- Tectum micro-echinate, scabrate or verrucate............. 10

$10+$ Porus margins flattend, porus membrane with cavities (varts), pori may be in slightly sunken areas giving the grain a dimpled appearance.

Thalictrum

- Porus margins clearly defined, more or less rounded in shape, pore not sunken.

Plantago-type 


\section{Chapter 7}

\section{Synthesis}

The southern Mongolia is situated in the triangle of the Mongolian High Pressure System (MHPS), the North Atlantic Oscillation (NAO) associated westerlies and Asian summer monsoon. Its geographical location is of interest for palaeo-vegetation and palaeo-climate studies and is considered to be very important to vegetation and climate changes. In order to know more about the late Quaternary vegetation and climate history, two lake archives (Bayan Tohomiin Nuur and Orog Nuur) were investigated. The BTN and ONW lake sediments provide records to improve the understanding of the palaeo-vegetation history and palaeo-climate development of the region during the last $50 \mathrm{ka} \mathrm{cal}$ BP.

The lake BTN is situated at about $1280 \mathrm{~m}$ elevation in the semiarid to arid Gobi Altai in southern Mongolia. This lake occupies a small catchment area of $1750 \mathrm{~km}^{2}$ with a flat surface and ephemeral streams. It is mostly dry during the year due to low precipitation and high evaporation. However, it has a remaining swamp area in the center which is fed by ground water from the surrounding alluvial fans. The studied site is located at the transition zone between the Gobi desert and the desert-steppes of southern Mongolia. Therefore, it is an archive very sensitive to vegetation and climate changes. Due to its unique geographical location and small catchment area, the lake sediments provide a peculiar record of the past local and regional developments of vegetation and climate (chapter 1 and 2).

The sediments of BTN were analysed for pollen, non-pollen palynomorphs, geochemistry and ostracod studies. These multidisciplinary high resolution analyses of the BTN revealed a detailed history of continental vegetation, climate dynamics and environmental change in high continental Asia during the last $15 \mathrm{ka} \mathrm{cal} \mathrm{BP} \mathrm{(chapter} 2$ and 3). The interdisciplinary analyses presented the first high resolution lake archive of Gobi desert.

Four semi-arid phases (Artemisia steppe) were interceded by short arid spells (Chenopodiaceae desert). The high values of the Glomus-type $(10-20 \%)$, high concentrations of titanium and high rubidium/strontium ratios in arid phases indicate a stronger terrigenous input into the lake due to sparse vegetation in the ctchment area of the lake. This is in coincident to the expansion of Ephedra shrubs which can be related to barren grounds. The first reconstructed phase at about 15.3 to $12.3 \mathrm{ka} \mathrm{cal} \mathrm{BP}$ is characterized by a relatively dry Artemisia desert-steppe with Chenopodiaceae desert and correlates to the late glacial stadials known from Northern Europe and north-east China as phases of forest reestablishment and increased delta ${ }^{18} \mathrm{O}$ values in ice cores from Greenland. This late glacial warm period lasted in NE-China until $12.5 \mathrm{ka}$ cal BP. It is followed by a pronounced climatic deterioration (12.3 -11.1 ka cal BP) of about 1200 years. This first arid phase indicates that the climate during the late glacial changed from wet towards more dry conditions equivalent to the Younger Dryas which is represented by a forest decline in north-east China and is considered a dry phase in mainy regions of Central Asia lasting from about 12.8 to $11.5 \mathrm{ka}$ cal BP. The delay of the Younger Dryas period of 
about 400 years might be attributed to uncertainities in the age-depth model. An early short and slight climatic deterioration at around 13.5 ka cal BP may reflect the Oldest Dryas period (13.9-13.8 ka cal BP) in north-east china. The first arid phase is followed by the rise in temperature and precipitation, marking the onset of the Holocene with prevailing relatively humid conditions. The humid period of the Holocene lasted until about $3.8 \mathrm{ka}$ cal BP, interrupted by arid oscillations at $8.6-7.6 \mathrm{ka}$ cal BP and $4.9-4.5 \mathrm{ka} \mathrm{cal}$ BP. The relatively humid conditions during the Holocene may coinside with the onset of higher effective moisture in continental Asia at around $11.5 \mathrm{ka}$ cal BP due to an abrupt intensification of the westerlies and summer monsoon system. The phase of climate amelioration during the early Holocene is replaced by a short arid spell between $8.6-7.6 \mathrm{cal}$ BP. This phase shows a climate shift from cold and dry conditions to warm and dry conditions as reflected by a gradual vegetation succession from Ephedra shrubs to Chenopodiaceae desert and can be correlated to the 8.2 ka event. The dry early Holocene is superceded by a wet middle Holocene. The climate amelioration at about $7.6 \mathrm{ka}$ cal BP marks the onset of middle Holocene. This abrupt chang to moister conditions exist till $4.9 \mathrm{ka} \mathrm{cal} \mathrm{BP}$. The most stable and relatively moist conditions (Artemisia steppe) occurred in the middle Holocene from 6.3 to 4.9 ka ca BP which represents Holocene climate optimum in the Gobi Altai, Mongolia. These correlations point to a climatic synchronicity with the northern hemisphere and most probably a stronger moisture input by the westerlies caused the mentioned Holocene climate optimum. Nevertheless, a combined influence of westerlies and the summer monsoon caused a quite humid phase just before the Holocene optimum, while bordering areas in the north and south were dry. The Holocene climate optimum in the Gobi Altai was suddenly replaced by an arid and cold spell at about $4.9 \mathrm{ka}$ cal BP might be due to the weakening of monsoonal influence in Central Asia since $7 \mathrm{ka}$ cal BP. The abrupt shift from semi-arid and moist to arid and cold climate is in consonance with a recorded minimum summer rainfall and the regional moisture deficit at about $4.9 \mathrm{ka}$ cal BP in NEChina. The geochemical record infers that the aridity in southern Mongolia increased after $3.8 \mathrm{ka}$ cal BP accompanied by the strengthening of aeolian processes, dune remobilization and lake desiccation. Pollen of trees, shrubs, grazed weeds and spores of coprophilous and plant infecting fungi are present only in low quantities. Fossil eggs of the intestinal parasite Trichuris are reported for the first time from Mongolia.

The results of this investigation show a general consistence with palaeoclimatic data from surrounding regions of Central Asia. Due to a different initiation and characteristic of climatic events as well as different regional influences within central Asia, a comparison to short term climatic changes in Mongolia and China is not always possible. The overall high correlation with superregional climate dynamics seems to be a peculiarity of the BTN record, while most of the Mongolian archives stress small-scale differences obscuring outreaching commonalities to some extent. We can conclude that the small catchment area of the BTN, its location at the transition from desert to semi-desert and the shallow character of the lake led the sediments of the BTN to become a highly sensitive and representative archive for climate and landscape change. 
The lake Orog Nuur (ONW) covers an area of approximately $129 \mathrm{~km}^{2}$ in a region on the margin of summer monsoon and westerlies in southwestern Mongolia. Lake ONW is located in the semiarid Gobi-Altai transition zone in the valley of lakes at about $1280 \mathrm{~m}$ elevation (chapter 4). The geochemical, granulometric, palynological and ostracod analyses from lake sediments of ONW have proved to serve as good archives for the reconstruction of vegetation and climate history. Such multiproxy studies are essential to reconstruct the vegetation and climate change and possibly the human impact during the past. However, we presented here the palynological results only. The research work on the geochemical and ostracod data is still in process and will be compiled soon.

High resolution pollen and non pollen palynomorph records from the sediments of lake ONW was used to reconstruct vegetation and climate history during the last $50 \mathrm{ka} \mathrm{cal} \mathrm{BP.} \mathrm{Our} \mathrm{findings} \mathrm{provide}$ the first pollen and spores evidences of the late Quaternary period for this semiarid region under the control of cobined influence of westerlies and Asian summer monsoon. The palynological results show seven major phases of climate change in response to the palaeovegetation analyses. Artemisia steppe desert prevailed between 49.5 and $44.7 \mathrm{ka}$ cal BP, indicating warm (interstadial) and semihumid conditions correlating to marine Oxygen Isotope stage 3. It was followed by a short semiarid and probably cool spell at about $44.7 \mathrm{ka}$ cal BP. The successive climate change from semiarid and cool climate to relatively humid and cold climate between 41.3 to $23.2 \mathrm{ka}$ cal BP corresponds to marine Oxygen Isotope stage 2. This is consistent with the findings from palaeoenvironmental records of lake Baikal, western China and northwestern Mongolia. Generally a humid and cold climate is recorded on the basis of palaeoshore-lines, geochemistry of Ostracoda in lacustrine sediments and on observation of alluvial fans in Inner Mongolia and Mongolia. Increase in temperature was observed at 23.2 and $22.7 \mathrm{ka}$ cal BP, marking the initiation of glacier retreat during the late glacial times. The warm and relatively dry period between 24 and $21 \mathrm{ka}$ was recorded from western China and called this as stage of evaporation. The slight difference in age period might be due to the regional differences in humidity for the dry lands in western China and Mongolia. It was followed by relatively humid and cool conditions from 22.7 to $18.9 \mathrm{ka}$ cal $\mathrm{BP}$, ratifying high precipitation and high lake levels at about $18 \mathrm{ka}$ from western Tibet. The high lake level at about $18 \mathrm{ka}$ is a subject of special discussion for palaeoecologists. It was followed by arid period of the climate lasted until late Holocene. Arid and cold indicating pollen (Chenopodiaceae and Ephedra shrubs) increases in abundance at about $18.9 \mathrm{ka}$ cal BP till about $11 \mathrm{ka}$ cal BP and point to hyperarid climatic conditions.

When we compare our results of both lake archives (BTN and ONW), they present complementary approaches to palaeo-climate knowledge. The multiproxy study of the BTN represents regular alterations of arid and semiarid conditions from late Glacial to late Holocene. The first arid phase correlates with the Younger Dryas and the second one with the 8.2 ka event. Relatively dry early Holocene is followed by a mid-Holocene climatic optimum. Such a high consistency of different climate data indicate superregional climate pattern of Central Asia. The palynological results of ONW 
indicate relatively arid and cold conditions during late Pleistocene to late Holocene rather than regular alterations of different climate pattern. The overall arid condition is the peculiarity of the ONW. Keeping in mind the difference in the locations of the both lake archives (BTN and ONW) to the summer monsoon, our findings emphasize to investigate the landscape development in detail to explore the contradictory results of climate change. Further studies about the vegetation and climate dynamics of continental Mongolia are needed to see the combined influence of westerlies and the monsoon system. The future research projects should concentrate on Gobi desert because it represents a transitional zone between the circulation systems of westerlies associated North Atlantic oscillation (NAO), Asian summer monsoon and the Mongolian High Pressure System (MHPS). Moreover, the available palaeo-climate data is not sufficient to understand the contradictory insight of palaeoenvironmental changes in the desert and semi desert region of continental Mongolia.

Continuation of further palaeoclimate studies would enhance the understanding of the past environmental changes and to get a projected view for future environmental change. The study would be helpful to observe short lived events and detect the complex spatial pattern climate history of Central Asia. 


\section{APPENDIX I \\ LIST OF IDENTIFIED POLLEN, FUNGAL SPORES, FERN SPORES, ALGAE AND ZOOLOGICAL REMAINS FROM LAKE SEDIMENTS OF BAYAN TOHOMIIN NUUR, OROG NUUR AND OLGOY NUUR, MONGOLIA}

- Morphological characteristics of pollen, fern spores, fungal spores, algae and zoological remains are described with the help of published literature (Faegri, K. and Iversen, J., 1989; Moore et al., 1999; Beug, 2004; Smith, 1986; Vanky, 1994; Van Geel et al., 2003, Van Gell presentation in international palynological congress, 2008; Bell, 2005)

- Photographs were sketched from the prepared slides of sediment samples by using Axiostar Plus (Zeiss) microscope (40x/0.65 resolution) and Moticam 2300 digital camera (3.0 M Pixel)

- All photographs are without scale

- All pictures are taken from fossil material, therefore, type slides and relevant literature should be studied for a careful identification

- It was not possible to sketch photograph of every pollen, fungal spore, fern spore, algae and zoological remains. Photographs of most common types are presented here 
Table A: List of identified pollen and fern spores

\begin{tabular}{|c|c|c|}
\hline Pollen type & General Morphology & $\begin{array}{l}\text { Photo } \\
\text { No. }\end{array}$ \\
\hline Chenopodiaceae & $\begin{array}{l}\text { Polypantoporate (periporate), psilate- scabrate, tectate, tectum without perforations, } \\
\text { micoechinate, each porus with differentiated annulus, usually with }>40 \text { pori }\end{array}$ & $1 \mathrm{a} / \mathrm{b} / \mathrm{c}$ \\
\hline Artemisia & $\begin{array}{l}\text { Globular, } 3 \text { lobed circular from polar view, tricolporate, psilate, regulate (having } \\
\text { spinules) or scabrate, exine has inner and outer layers, outer thicker than inner, pores } \\
\text { oblong, calpus wider in middle and narrow at both ends, pori margins ruminate or } \\
\text { irregular }\end{array}$ & $2 \mathrm{a} / \mathrm{b} / \mathrm{c}$ \\
\hline Matricaria-type & Echinate to verrucate, tricolporate, membrane rough, columellae visible under tectum & $3 \mathrm{a} / \mathrm{b} / \mathrm{c} / \mathrm{d}$ \\
\hline Poaceae & $\begin{array}{l}\text { Spheriodal to suboblate, monoporate, pore surrounded by annulus and operculum, } \\
\text { psilate, scabrate, tectate }\end{array}$ & $4 \mathrm{a} / \mathrm{b} / \mathrm{c}$ \\
\hline Betula & $\begin{array}{l}\text { Psilate or scabrate, trizonoporate (pori in equatorial zone), vestibulate pori, vestibulae } \\
\text { conical with slanting sides }\end{array}$ & $5 \mathrm{a} / \mathrm{b}$ \\
\hline Thalictrum & $\begin{array}{l}\text { Polypantoporate (periporate), spheriodal, apolar, microechinate, pori margins flattend, } \\
\text { pores membranes with cavities, no annulus, pori in slightly sunken areas giving the } \\
\text { grain a dimpled appearance }\end{array}$ & $6 \mathrm{a} / \mathrm{b}$ \\
\hline Haloxylon-type & $\begin{array}{l}\text { Pantoporate (periporate), pori usually 6-12, spheriodal, pore plate and tectum } \\
\text { scabrate }\end{array}$ & $\ldots$ \\
\hline Plantago & $\begin{array}{l}\text { Round with a thin cobbly wall, with network of irregular verrucae, pantoporate } \\
\text { (periporate), apolar, tectum aerolate or scabrate, operculate or non operculate annulus }\end{array}$ & 7 \\
\hline Caryophyllaceae & $\begin{array}{l}\text { Polypantoporate (periporate), apolar or isopolar, spheriodal to prolate spheriodal, } \\
\text { reticulate or reticulate scabrate, grain with clear annulus, tectate, radially symmetrical }\end{array}$ & $8 \mathrm{a} / \mathrm{b} / \mathrm{c}$ \\
\hline Brassicaceae & Tricolporate, reticulate, trilobate & 9 \\
\hline Pinus Diploxylon-type & $\begin{array}{l}\text { Vesiculate (saccate), inaperturate, abrupt transition between structure of air sac and } \\
\text { that of the wall of the grain body, colpus membrane dotted }\end{array}$ & $10 \mathrm{a} / \mathrm{b}$ \\
\hline Pinus Haploxylon-type & Vesiculate (saccate), inaperturate, colpus membrane smooth & $11 \mathrm{a} / \mathrm{b}$ \\
\hline Picea & $\begin{array}{l}\text { Bisaccate (vesiculate), inaperturate, usually } 75 \mathrm{um} \text {, smooth transition between } \\
\text { bladder and body }\end{array}$ & $12 \mathrm{a} / \mathrm{b}$ \\
\hline Abies & $\begin{array}{l}\text { Bisaccate, inaperturate, usually }>80 \mathrm{um} \text {, angular transition between bladder and } \\
\text { body, wall opposite the bladder is uneven and thin }\end{array}$ & $\ldots$ \\
\hline Ulmus & $\begin{array}{l}\text { Tetra-penta-hexazonoporate,echinate, pori slightly protruding, suprareticulte } \\
\text { reticulum or softly regulate }\end{array}$ & $13 \mathrm{a} / \mathrm{b}$ \\
\hline Ephedra distachya-type & $\begin{array}{l}\text { Oval shape, polyplicate, inaperturate, longitudinal ridges (groves or colpi) few (3-8) } \\
\text { and branched }\end{array}$ & $14 \mathrm{a} / \mathrm{b}$ \\
\hline Ephedra fragilis-type & $\begin{array}{l}\text { Oval shape, polyplicate, inaperturate, longitudinal ridges (groves or colpi) many } \\
\text { (more than 10) and unbranched }\end{array}$ & $15 \mathrm{a} / \mathrm{b}$ \\
\hline Rheum & $\begin{array}{l}\text { Isopolar, radially symmetrical, tricolporate, tectum densely punctuate, finely scabrate, } \\
\text { sexine as thick as nexine }\end{array}$ & $16 \mathrm{a} / \mathrm{b} / \mathrm{c}$ \\
\hline Nitraria & $\begin{array}{l}\text { Prolate (circular), polycolporate,striate, ectocolpus long, narrow with acute ends, } \\
\text { sexine thinner than nexine }\end{array}$ & $17 \mathrm{a} / \mathrm{b} / \mathrm{c}$ \\
\hline Salix & $\begin{array}{l}\text { Spheriodal to subspheriodal or prolate, tricolporate, finely reticulate or striate } \\
\text { reticulate, outline margin microwavy having clear margo with SEM, reticulation of } \\
\text { both muri and lumina decreases in size near the furrows }\end{array}$ & $18 \mathrm{a} / \mathrm{b}$ \\
\hline Convolvulus & $\begin{array}{l}\text { Suboblate or oblate-spheriodal,tectum perforated, psilate, trizonocolpate, columellae } \\
\text { branched, nexine thinner than sexine }\end{array}$ & $19 \mathrm{a} / \mathrm{b}$ \\
\hline
\end{tabular}




\begin{tabular}{|c|c|c|}
\hline Rumex-type & Oblate-spheriodal to prolate, micro reticulate, tri-tetracolporate, pores lolongate & 20 \\
\hline Senecio-type & Subprolate, tricolporate, echinate, columellae branched, spines with conical base & $21 \mathrm{a} / \mathrm{b}$ \\
\hline Liguliflorae & Fenestrate, echinate, lophate, tricolporate & $22 \mathrm{a} / \mathrm{b}$ \\
\hline Limonium & Oblate-spheriodal, reticulate tectum with regular pattern of muri, tricalpate & $23 \mathrm{a} / \mathrm{b}$ \\
\hline Alnus & $\begin{array}{l}\text { Oblate, scabrate to rugulate, stephanoporate, usually } 4-5 \text { pori in equatorial plane with } \\
\text { distinctive lines of thickening (acri) joining the pori in both hemispheres }\end{array}$ & 24 \\
\hline Hippophae & $\begin{array}{l}\text { Trizonocolporate, mesocolpium convex, colpi long, curving round the margin, } \\
\text { circular-elliptic endopori,each porus has a constriction to the colpus, festigia } \\
\text { prominent, psilate to scabrate-verrucate }\end{array}$ & $25 \mathrm{a} / \mathrm{b}$ \\
\hline Tribulus terrestris & $\begin{array}{l}\text { Spheriodal, or oblate spheriodal, pantoporate, coarsely reticulate, porus circular with } \\
\text { or without annulus }\end{array}$ & $26 \mathrm{a} / \mathrm{b}$ \\
\hline Calligonum-type & Grain symmetric, ispoalr, tricolpate, reticulate-faveolate & $27 \mathrm{a} / \mathrm{b}$ \\
\hline Myriophyllum spicatum & $\begin{array}{l}\text { Psilate, grain oblate, stephanoporate, usually } 4 \text { or } 5 \text { pores sometimes } 3 \text {, pores } \\
\text { meridionally elongated with endexinous annuli, equatorial limb regular, pores } \\
\text { equidistant, annulus distanct and produding }\end{array}$ & $28 \mathrm{a} / \mathrm{b}$ \\
\hline $\begin{array}{l}\text { Myriophyllum } \\
\text { verticellatum }\end{array}$ & $\begin{array}{l}\text { Psilate, grain oblate, stephanoporate, usually } 4 \text { pores sometimes } 3 \text { or } 5 \text {, pores } \\
\text { meridionally elongated with endexinous annuli, equatorial limb regular, pores } \\
\text { equidistant, annulus externally flat and not protuding }\end{array}$ & 29 \\
\hline $\begin{array}{l}\text { Polygonum aviculare- } \\
\text { type }\end{array}$ & $\begin{array}{l}\text { Grain elliptic or rectangular-obtuse, columellae unbranched, tricolporate, psilate - } \\
\text { scabrate }\end{array}$ & $\ldots$ \\
\hline Sparganium-type & $\begin{array}{l}\text { Grain reticulate, heterobrochate, monoporate, pore small and distinct, no annulus, } \\
\text { diameter less than half that of the margin }\end{array}$ & $30 \mathrm{a} / \mathrm{b}$ \\
\hline Allium-type & $\begin{array}{l}\text { Grain more or less circular, monad, monosulcate (monocolpate) or monosulcate- } \\
\text { operculate, sulcus narrow at the equator and widens at the poles, sulcus ends blunt, } \\
\text { broad and rounded, heteropolar,bilaterally symmetrical }\end{array}$ & $31 \mathrm{a} / \mathrm{b}$ \\
\hline $\begin{array}{l}\text { Gentiana pneumonentha- } \\
\text { type }\end{array}$ & $\begin{array}{l}\text { Grain elliptic and slightly pointed at the poles, about } 30 \mathrm{um} \text {, trizonocolporate, pori } \\
\text { distinct, striate- regulate, striae short and meridional }\end{array}$ & $\ldots$ \\
\hline Apiaceae & $\begin{array}{l}\text { Pea nut shaped, tricolporate, costae (internal thickenings) surround a porus, striate, } \\
\text { rugulate or psilate }\end{array}$ & $\ldots$ \\
\hline $\begin{array}{l}\text { Potamogeton pectinatus- } \\
\text { type }\end{array}$ & $\begin{array}{l}\text { Spheriodal, inaperturate, apolar, radially symmetrical, tectum coarsely reticulate with } \\
\text { irregular pattern of muri, lumina variable in size and shape }\end{array}$ & 32 \\
\hline Anemone-type & $\begin{array}{l}\text { Trizonocolpate, tectum proceses more or less irregular in distribution, verrucate, } \\
\text { verrucae rounded, columellae monomorphic and appear as white dots in high focus, } \\
\text { tectum is smooth, densely perforate }\end{array}$ & $\ldots$ \\
\hline Cyperaceae & $\begin{array}{l}\text { Pear shaped, inaperturate, psilate, appear as infolded spheres with double edges of } \\
\text { the folds thickened, heteropolar having thin areas (lacunae) }\end{array}$ & 33 \\
\hline Genista group & $\begin{array}{l}\text { Tricolporoidatae, circular to rhomboic-obtuse, suprareticulate or faveolate, porus } \\
\text { indistinct with a ruptured area at the equator }\end{array}$ & $\ldots$ \\
\hline Haplophyllum & $\begin{array}{l}\text { Isopolar, monad, radially symmetrical, tricolporate, colpi with acute ends, membrane } \\
\text { granular, striate, or striate -reticulate }\end{array}$ & $\ldots$ \\
\hline cf. Ilex & $\begin{array}{l}\text { Spheriodal to prolate, trizonocolpate, clavate, clavae free, small clavae scattered } \\
\text { beneath the large ones }\end{array}$ & 34 \\
\hline Juniperus & $\begin{array}{l}\text { Inaperturate, gemmate sculpture, apolar, surface unevenly granular, grain commonly } \\
\text { split }\end{array}$ & $\ldots$ \\
\hline Lamiaceae & $\begin{array}{l}\text { Prolate or sub-spheriodal, tricolpate or hexacolpate, stephanocolpate, reticulate, } \\
\text { furrows straight and narrow, muri smooth, } 35-50 \mathrm{um}\end{array}$ & $\cdots$ \\
\hline
\end{tabular}




\begin{tabular}{|c|c|c|}
\hline Larix & Spheriodal, inaperturate, psilate & $\ldots$ \\
\hline Lemna & $\begin{array}{l}\text { Spheriodal, apolar, monoporate, tectum spinulate-punctate or scabrate, pores circular } \\
\text { and small }\end{array}$ & $\ldots$ \\
\hline Mentha-type & $\begin{array}{l}\text { Spheriodal to prolate, Staphanocolphate, usually } 6 \text { colpi, reticulte, columellae } \\
\text { restricted to muri, muri not beaded }\end{array}$ & $35 \mathrm{a} / \mathrm{b}$ \\
\hline Myricaria germanica & $\begin{array}{l}\text { Sub-prolate, tricolpate, colpus long and sunken with acute ends, aerolate, trilobed in } \\
\text { polar view }\end{array}$ & $\ldots$ \\
\hline Papaver rhoeas-type & $\begin{array}{l}\text { Trizonocolpate, echinate, columellae of the same length all over the surface, } \\
\text { infrareticulate }\end{array}$ & $\ldots$ \\
\hline Potentilla-type & Tricolporiadate, striate & 36 \\
\hline Quercus & $\begin{array}{l}\text { Prolate, trizonocolpate, scabrate to verrucate with elements of various size, verrucae } \\
\text { elongated and unevenly distributed, tectum without perforations }\end{array}$ & $\ldots$ \\
\hline Ranunculus acris-type & $\begin{array}{l}\text { Trizonocolpate, microechinate, colpi usually wide and granulate, columellae } \\
\text { dimorphic; sparse thick columellae irregularly arranged among numerous fine } \\
\text { columellae }\end{array}$ & $\ldots$ \\
\hline Sanguisorba officinalis & $\begin{array}{l}\text { Oblate-globular, hexazonocolporate, one porus per colpus, tectae operculum, } \\
\text { operculum as broad as the intercolpium, psilate-scabrate-echinate }\end{array}$ & $\ldots$ \\
\hline Solanum nigrum-type & Tricolporoidatae,triate, vallae fine and without dense structure, perforations distinct, & $\cdots$ \\
\hline Sorbus-type & Subprolate - suboblate, regulate-striate, striae branched, trizonocolporate & $\ldots$ \\
\hline Acer-type & Tricolpate, striate or striate rugulate, striae meridional, exine perforated & $\ldots$ \\
\hline Alisma- type & $\begin{array}{l}\text { Polypantoporate, tectum perforate, intrareticulate, pori appear sunken (exine thinner at } \\
\text { the porus edge compared to the mesoporium), sunken porus is surrounded by fine and } \\
\text { short columellae forming a diffuse annulus, porus membrane granulate }\end{array}$ & $\ldots$ \\
\hline Monolete spore & Grain bean shaped, psilate, monocolpate & 37 \\
\hline Polypodium & Grain bean shaped, verruculose, monocolpate & 38 \\
\hline Pterdium (trilete spore) & Spore psilate, triangular-obtuse with concave sides, trilete scar with short arms & 39 \\
\hline
\end{tabular}

\section{Table B: List of identified fungal spores, algae and zoological remains}

\begin{tabular}{|c|c|c|}
\hline Fungus/Alga type & General Morphology & $\begin{array}{l}\text { Photo } \\
\text { No. }\end{array}$ \\
\hline Alternaria-type & Psilate to scabrate, spores $2-10$ born on a stalk with abeaked apical cell & $40 \mathrm{a} / \mathrm{b} / \mathrm{c}$ \\
\hline Glomus-type & spore globose, occur isolated or in clusters, variable in size & $41 \mathrm{a} / \mathrm{b}$ \\
\hline Cercophora-type & $\begin{array}{l}\text { Ascospores } 13-27 \times 6-14 \mathrm{um} \text {, truncated at the basal side and tapering at the apical } \\
\text { end, sub-apical pore is } \sim 0.7 \mathrm{um} \text { in diameter }\end{array}$ & $42 \mathrm{a} / \mathrm{b}$ \\
\hline Thecaphora-type & Basidiospores, occur in groups of cells, pore is $\sim 3 \mathrm{um}$, surface has a protuberance & $43 \mathrm{a} / \mathrm{b}$ \\
\hline Gelasinospora-type & $\begin{array}{l}\text { Ascospores ellipsoid, spore surface black ornamented with evenly hyline pits, spore } \\
\text { walls thick }\end{array}$ & $44 \mathrm{a} / \mathrm{b}$ \\
\hline Leptosphaeria & Ascospores ellipsoidal, septate, usually $4-5$ celled, subapical cell large in size & $45 \mathrm{a} / \mathrm{b}$ \\
\hline Drechslera-type & $\begin{array}{l}\text { Spores may be straight, slightly curved, club-shaped, cylindrical, or elliptical, } \\
\text { smooth or warty, occur individually, thick walled, the septa between cells appear to } \\
\text { be incomplete (pseudosepta) }\end{array}$ & $\ldots$ \\
\hline Chetomium & $\begin{array}{l}\text { Ascospores one celled, lemon shaped, light brown, 6-12 ×4-9 um, somewhat } \\
\text { flattened in one plane }\end{array}$ & $\ldots$ \\
\hline Cladosporium-type & $\begin{array}{l}\text { Spores smooth or minutely rough, sometime with warty wall, occur in long } \\
\text { branching chains, spherical, barrel-like or lemon-shaped }\end{array}$ & $46 \mathrm{a} / \mathrm{b}$ \\
\hline
\end{tabular}




\begin{tabular}{|c|c|c|}
\hline Caryospora-type & $\begin{array}{l}\text { Ascospores usually two celled, sometime with additional septa, ellipsoid, cells } \\
\text { rounded at apices,smooth }\end{array}$ & $47 \mathrm{a} / \mathrm{b}$ \\
\hline $\begin{array}{l}\text { Caryospora callicarpa- } \\
\text { type }\end{array}$ & $\begin{array}{l}\text { Ascospores usually two celled, sometime with additional septa, ellipsoid, cells } \\
\text { rounded at apices, striate }\end{array}$ & $48 \mathrm{a} / \mathrm{b}$ \\
\hline Tilletia-type & Spores globose, sculpture has anastomosing grooves & $49 \mathrm{a} / \mathrm{b}$ \\
\hline Podospora-type & $\begin{array}{l}\text { Ascospores one celled, ellipsoidal, smooth brown, } 39-48 \times 16-23 \text { um, pore is } \\
\text { protruding directly below the apex and } \sim 2 \text { um in diameter, pore is surrounded by } \\
\text { annulus, basal end is bluntly conical }\end{array}$ & 50 \\
\hline Sporomiella-type & $\begin{array}{l}\text { Ascospores three to many septate, septa transverse to oblique, smooth, brown, every } \\
\text { cell has elongated germ slit extending the entire length of the cell, } 14-21 \times 11-17 \mathrm{um} \text {, }\end{array}$ & $51 \mathrm{a} / \mathrm{b}$ \\
\hline Diporotheca & $\begin{array}{l}\text { Ascospores biseptate, fusiform, brackish brown or light brown, both ends truncate } \\
\text { having a germ pore }\end{array}$ & $52 \mathrm{a} / \mathrm{b}$ \\
\hline Coniochaeta ligniaria & Ascospores one celled, ellipsoid, brown, bilaterally flattened, with long germ slit & 53 \\
\hline Valsaria-type & $\begin{array}{l}\text { Uniseptate ascospores, } 42 \times 22 \text { um inclusive of the velum which forms longitudinal } \\
\text { ribs and an equatorial ring around the septum }\end{array}$ & $54 \mathrm{a} / \mathrm{b}$ \\
\hline Entorrhiza & Globose or subglobose teliospore, smooth to finely or coarsely verrucate & 55 \\
\hline Pleospora-type & $\begin{array}{l}\text { Ascospores ellipsoid or oblong, brown, muriform, } 7 \times 2-3 \text {-septate, ascoma wall cells } \\
\sim 10 \text { um in diameter }\end{array}$ & 56 \\
\hline Xylariaceae & $\begin{array}{l}\text { Ascospores ellipsoidal, one celled with long itudinal germ slit, perithecia embedded } \\
\text { in stroma }\end{array}$ & 57 \\
\hline Curvularia & Sopre crescent shape, psilate having mostly five cells & $58 \mathrm{a} / \mathrm{b}$ \\
\hline Pithomyces chartarum & $\begin{array}{l}\text { Spores brown, barrel shaped, somewhat roughened, several celled with cell divisions } \\
\text { running both horizontally and vertically, colourless }\end{array}$ & 59 \\
\hline Hypocopra-type & $\begin{array}{l}\text { Ascospores flattened on one side, ellipsoidal in other view, surrounded by a } \\
\text { gelatinous sheath }\end{array}$ & $\cdots$ \\
\hline Delitschia-type & $\begin{array}{l}\text { Ascospores dark, ellipsoidal, mainly two celled with longitudinal straight or sinuous } \\
\text { germ slit }\end{array}$ & $60 \mathrm{a} / \mathrm{b}$ \\
\hline Sordaria-type & $\begin{array}{l}\text { Ascospores one celled, ellipsoidal, } 16-31 \times 10-17 \mathrm{um} \text {, apical pore } 1.5 \mathrm{um} \text {, wall } \\
\text { around apical pore is thick and dak, basal pore of the pore is flattened }\end{array}$ & 61 \\
\hline Trichodelitschia-type & Ascospores two celled, dark, each cell having a polar germ pore & $\cdots$ \\
\hline Arnium-type & $\begin{array}{l}\text { Ascospores one celled, ellipsoidal, } 86 \times 30-36 \text { um with } \sim 1.5 \text { um wide pore at both } \\
\text { ends }\end{array}$ & 62 \\
\hline $\begin{array}{l}\text { Munkovalsaria/Montagnul } \\
\text { a }\end{array}$ & Ascospores fusiform, reddish brown, 1-septate, both ends pointed & $\ldots$ \\
\hline Neurospora-type & $\begin{array}{l}\text { Ascospores ellipsoidal, non septate, brown with two protruding apical pores, } \\
\text { contains longitudinal grooves }\end{array}$ & 63 \\
\hline Urocystis & Ustilospore subglobose, ellipsoid, ovoid or angular, verruculose & $\cdots$ \\
\hline Pediastrum & $\begin{array}{l}\text { Coenobium circular in outline, cells irregular or polygonal, cell wall granular, } \\
\text { marginal cells have two lobes, ending by long narrow hyline abrupt processes }\end{array}$ & 64 \\
\hline Volvocaceae & Each cell round with S-like-split-opening, colourless, having rough surface & 65 \\
\hline Botrycococcus & $\begin{array}{l}\text { Yellow brown to yellow colonies, cells elongated,obviate or cylindrical, enclosed by } \\
\text { a muscilage, sometimes apical ends of cells emerged from the muscilagenous cups }\end{array}$ & 66 \\
\hline Chironomids & Mandibles of invertebrates & $67 \mathrm{a} / \mathrm{b}$ \\
\hline Trichuris & Egg cuticle of parasitic Nematodes & 68 \\
\hline Foraminefera & $\begin{array}{l}\text { Rhizopod cells composed of a series of increasing size chmbers.there are 6-8 } \\
\text { chambers in one convolution }\end{array}$ & 69 \\
\hline
\end{tabular}


Table C: List of unknown pollen, fungal spores, algae and zoological remains. Most of them occure very rarely (one to two times) and not included in the diagrams. The supposed names of fungal spores start with letter $\mathrm{T}$ are based on matching with the spores type reported by Van Gell, 2008 (slide presentation in international palynological congress, Bonn). ONW is a supposed name stand for Orog Nuur

\begin{tabular}{|c|c|c|c|}
\hline Supposed Name & Photo No. & Supposed Name & Photo No. \\
\hline T 1032 & 70 & Unknown 2 & 98 \\
\hline T 1042 & $71 \mathrm{a} / \mathrm{b}$ & Unknown 3 & 99 \\
\hline T 1045 & 72 & Unknown 4 & 100 \\
\hline Т 1051 & 73 & Unknown 5 & $101 \mathrm{a} / \mathrm{b}$ \\
\hline T $1058 \mathrm{~A} 1$ & 74 & Unknown 6 & 102 \\
\hline T $1061 \mathrm{~A}$ & 75 & Unknown 7 & 103 \\
\hline T $1061 \mathrm{D}$ & 76 & Unknown 8 & 104 \\
\hline ONW-II-ab & 77 & Unknown 9 & 105 \\
\hline ONW-II-abc (cf. Spirogyra) & 78 & Unknown 10 & 106 \\
\hline ONW-II-type 1 & $79 \mathrm{a} / \mathrm{b}$ & Unknown 11 & 107 \\
\hline ONW-II-type 2 (cf.Rotatoria & 80 & Unknown 12 & 108 \\
\hline egg) & & Unknown 13 & 109 \\
\hline ONW-II-type $\quad 3$ (cf.Rotatoria & $81 \mathrm{a} / \mathrm{b}$ & Unknown 14 & 110 \\
\hline egg) & & Unknown 15 & 111 \\
\hline ONW-II-type $\quad 4$ (cf.Rotatoria & $82 \mathrm{a} / \mathrm{b}$ & Unknown 16 & 112 \\
\hline egg) & & Unknown 17 & 113 \\
\hline ONW-II-type 5 & $83 \mathrm{a} / \mathrm{b}$ & Unknown 18 & 114 \\
\hline ONW-II-type 6 & 84 & Unknown 19 & 115 \\
\hline cf.Taniola rudis & 85 & Unknown 20 & 116 \\
\hline cf.Lembosina & 86 & Unknown 21 & 117 \\
\hline cf. Phoma glomerata & 87 & Unknown 22 & 118 \\
\hline cf. Ascobolus & 88 & Unknown 23 & $119 \mathrm{a} / \mathrm{b}$ \\
\hline cf. Geoglosum & 89 & Unknown 24 & 120 \\
\hline cf. Microsporum & 90 & Unknown 25 & 121 \\
\hline cf. Fusicladum & 91 & Unknown 26 & 122 \\
\hline cf. Puccinia teletospore & $92 \mathrm{a} / \mathrm{b}$ & Unknown 27 & 123 \\
\hline cf. Tetraporina & 93 & Unknown 28 & 124 \\
\hline cf. Meliola & $94 \mathrm{a} / \mathrm{b}$ & Unknown 29 & 125 \\
\hline cf. Cerebella/Stemphyllum & 95 & Unknown 30 & 126 \\
\hline cf. Acrodictys globulosa & 96 & Unknown 31 & $127 \mathrm{a} / \mathrm{b}$ \\
\hline \multirow[t]{2}{*}{ Unknown 1} & $97 \mathrm{a} / \mathrm{b}$ & Unknown 32 & $128 \mathrm{a} / \mathrm{b}$ \\
\hline & & Unknown 33 & 129 \\
\hline
\end{tabular}


Plate 1: Showing pollen from 1a to 10b

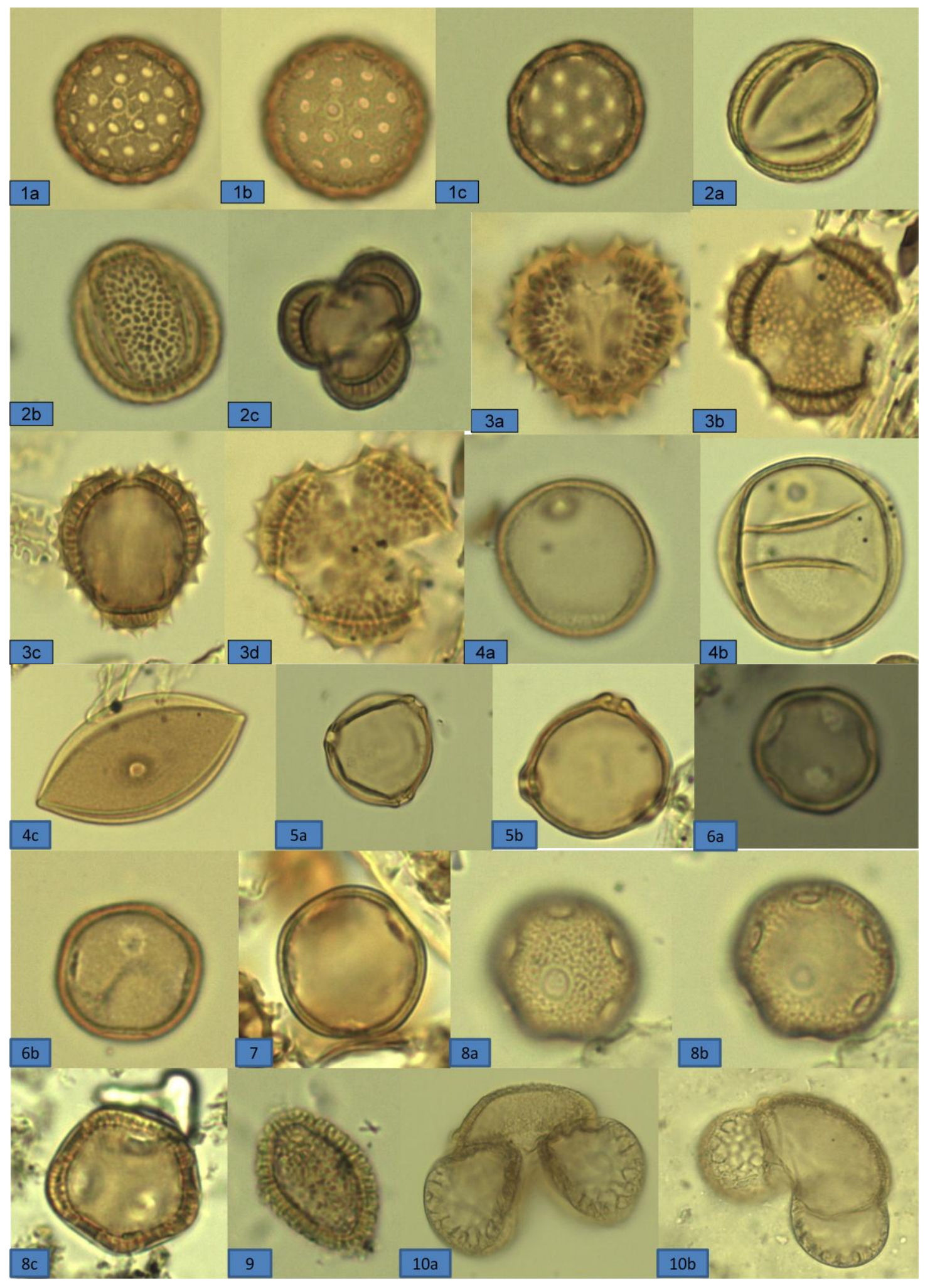


Plate 2: Showing pollen from 11a to 25a

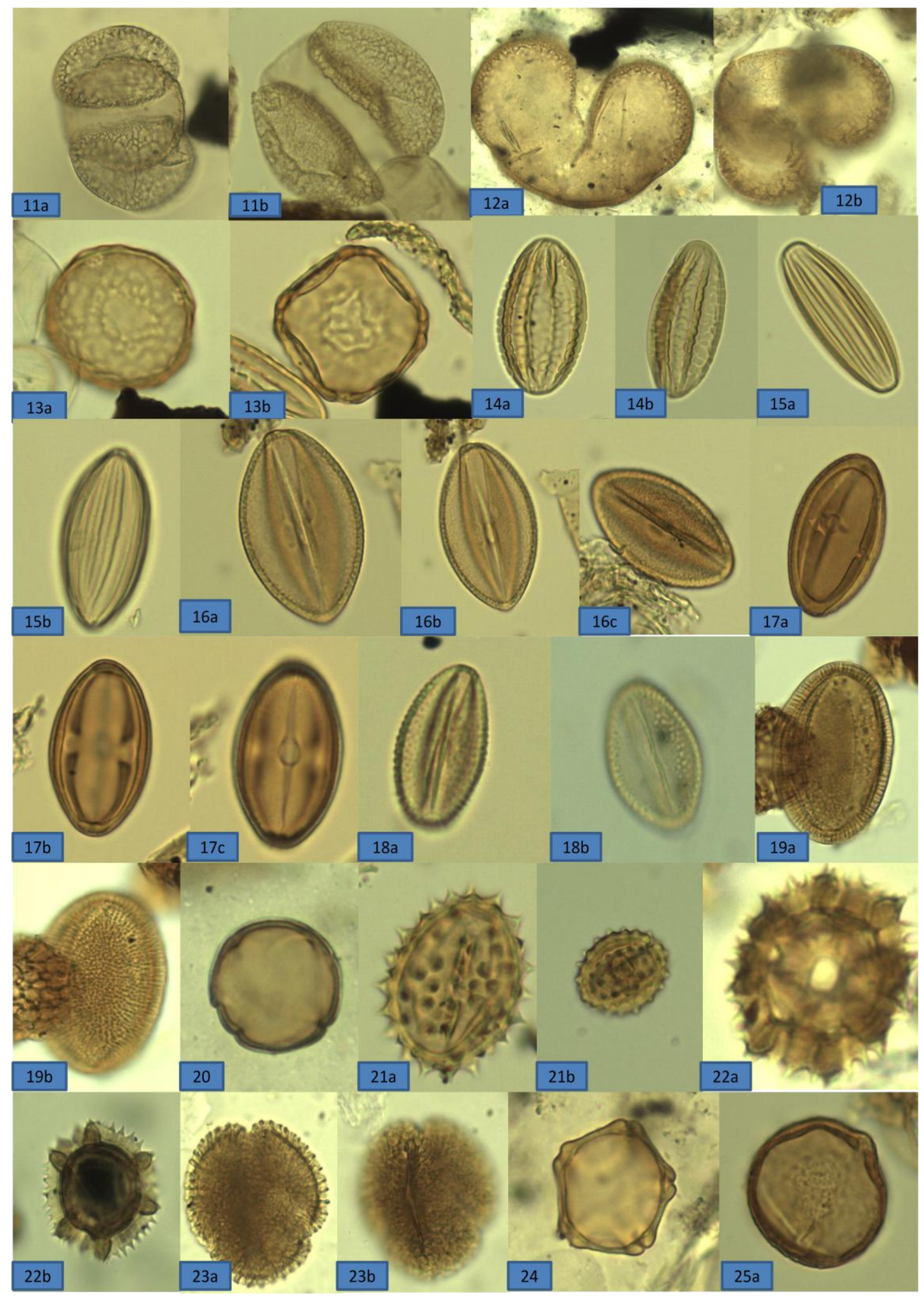


Plate 3: Showing pollen, fern spores and fungal spores from 25b to 42a

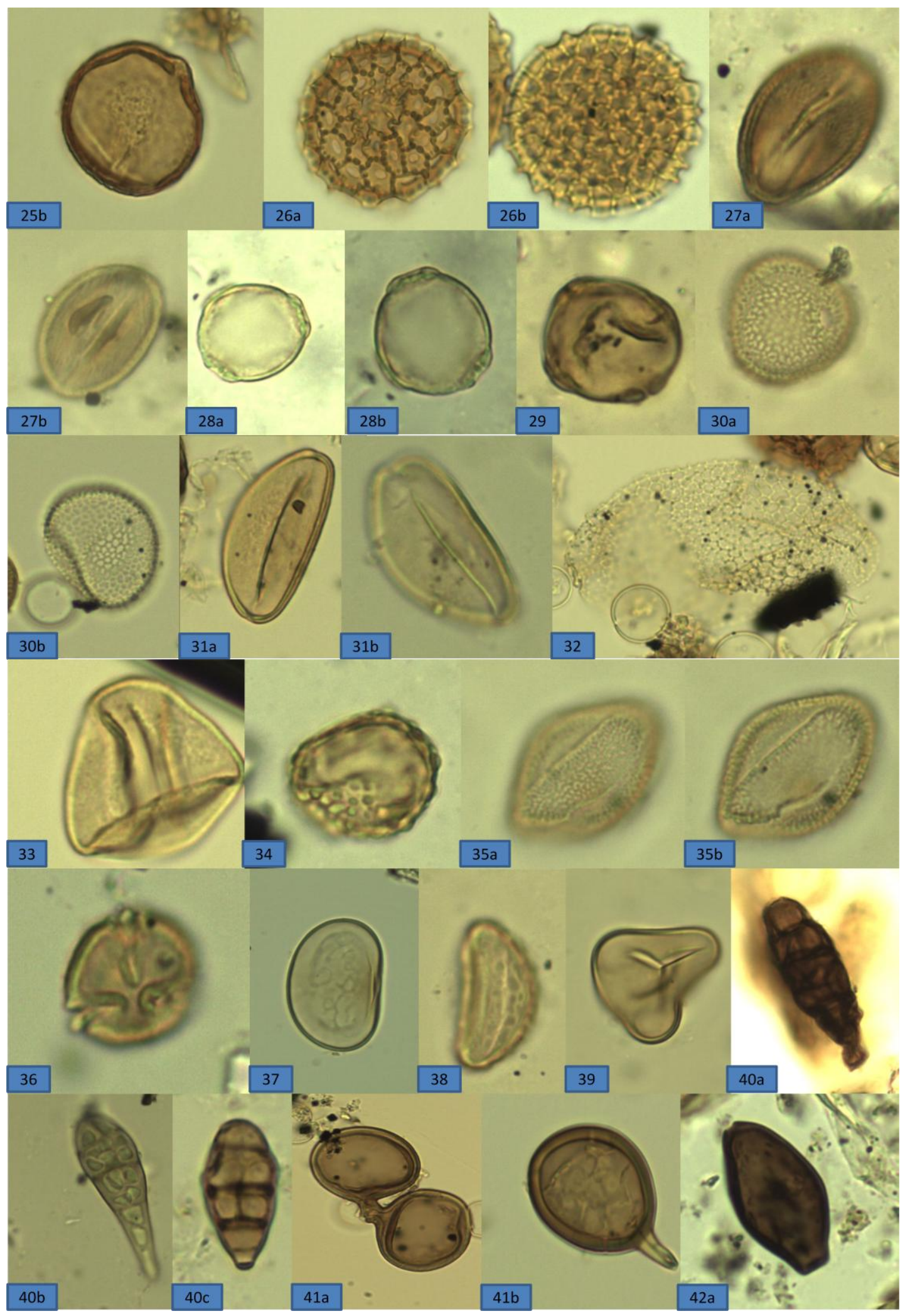


Plate 4: Showing Pollen fungal spores from 42b to 60b

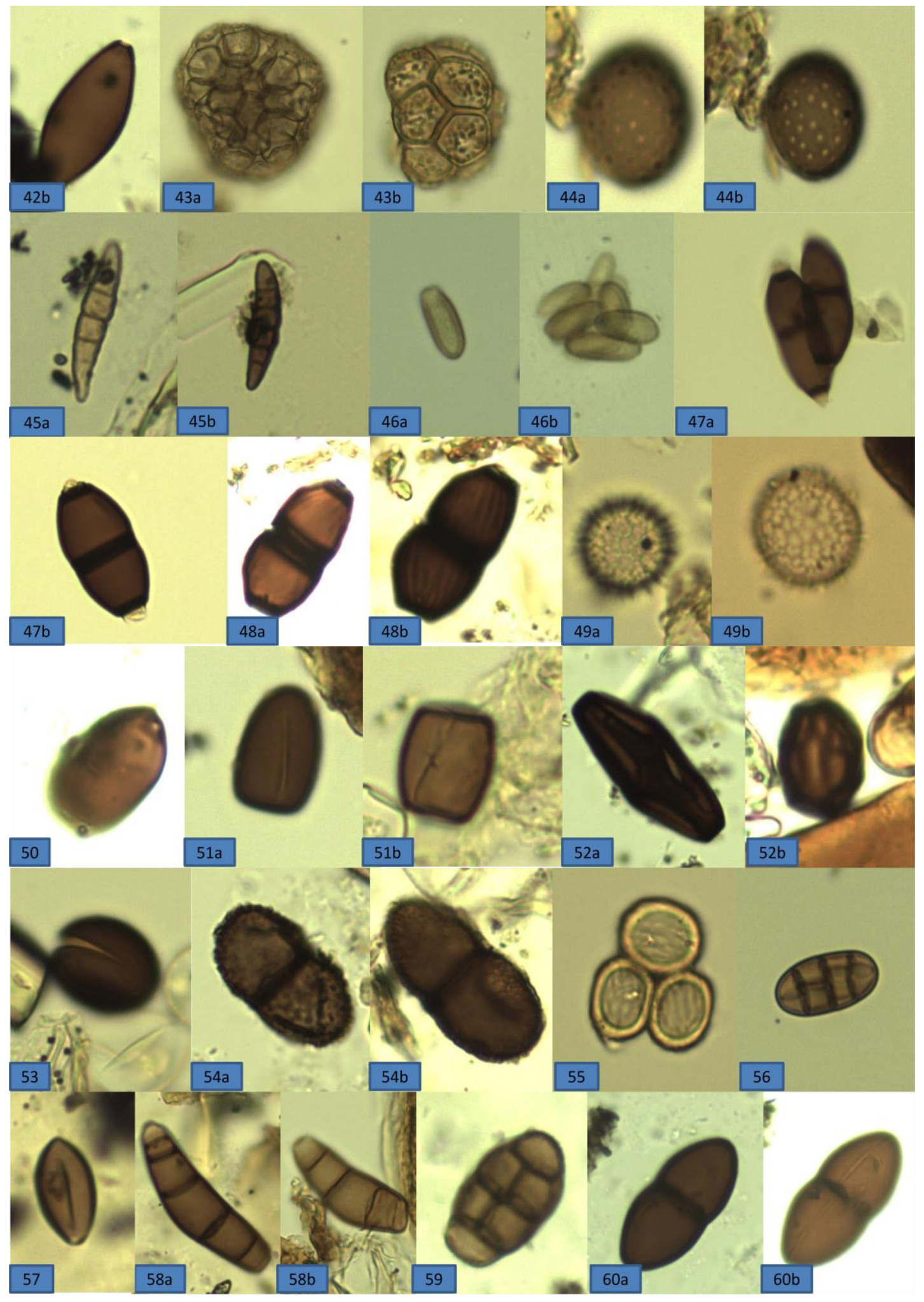


Plate 5: Showing fungal spores, algae, zoologicalremains and some unknown taxa from 61 to 85

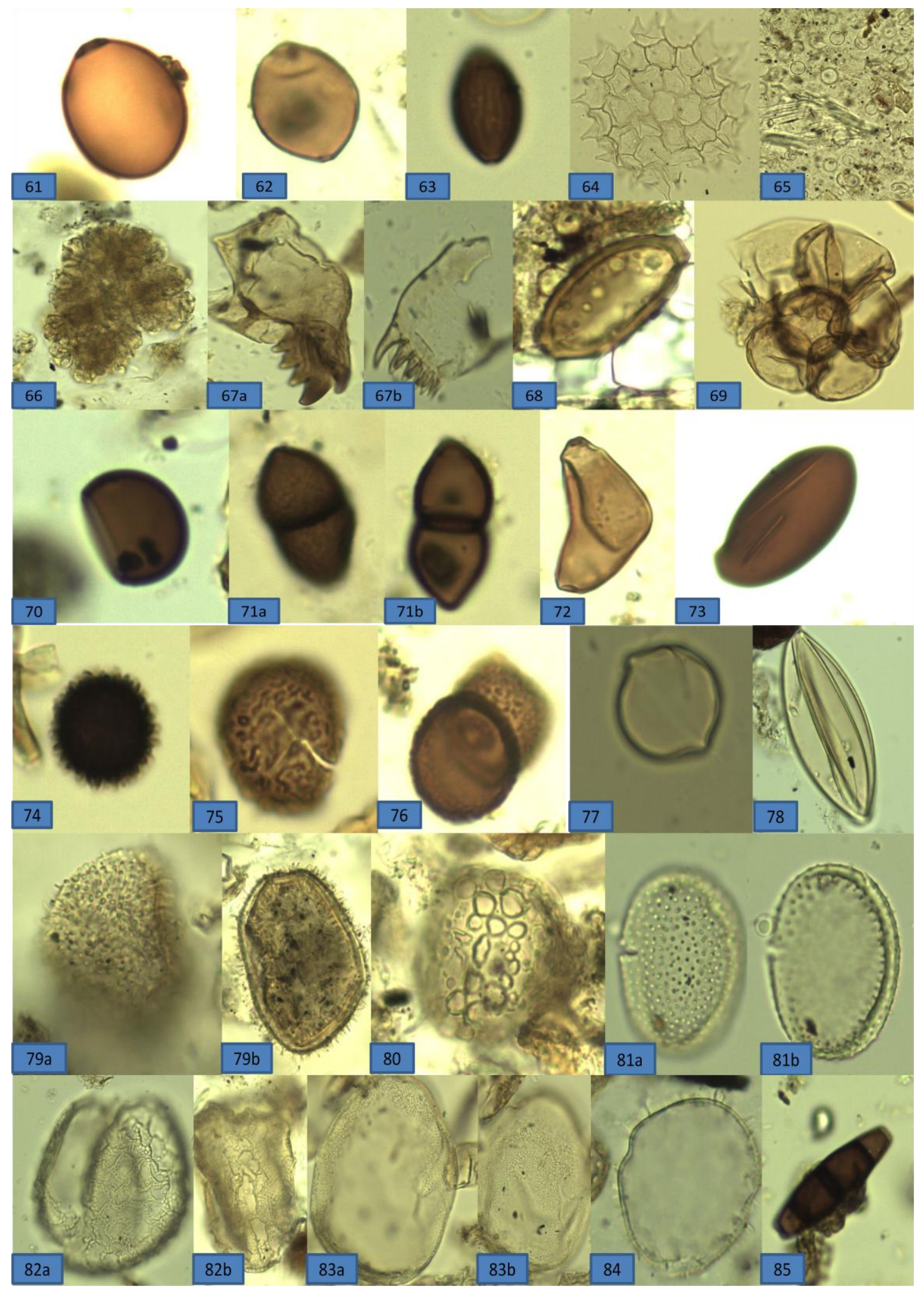


Plate 6: Showing unknown pollen, fungal spores, algae and zoologicalremains from 86 to 129

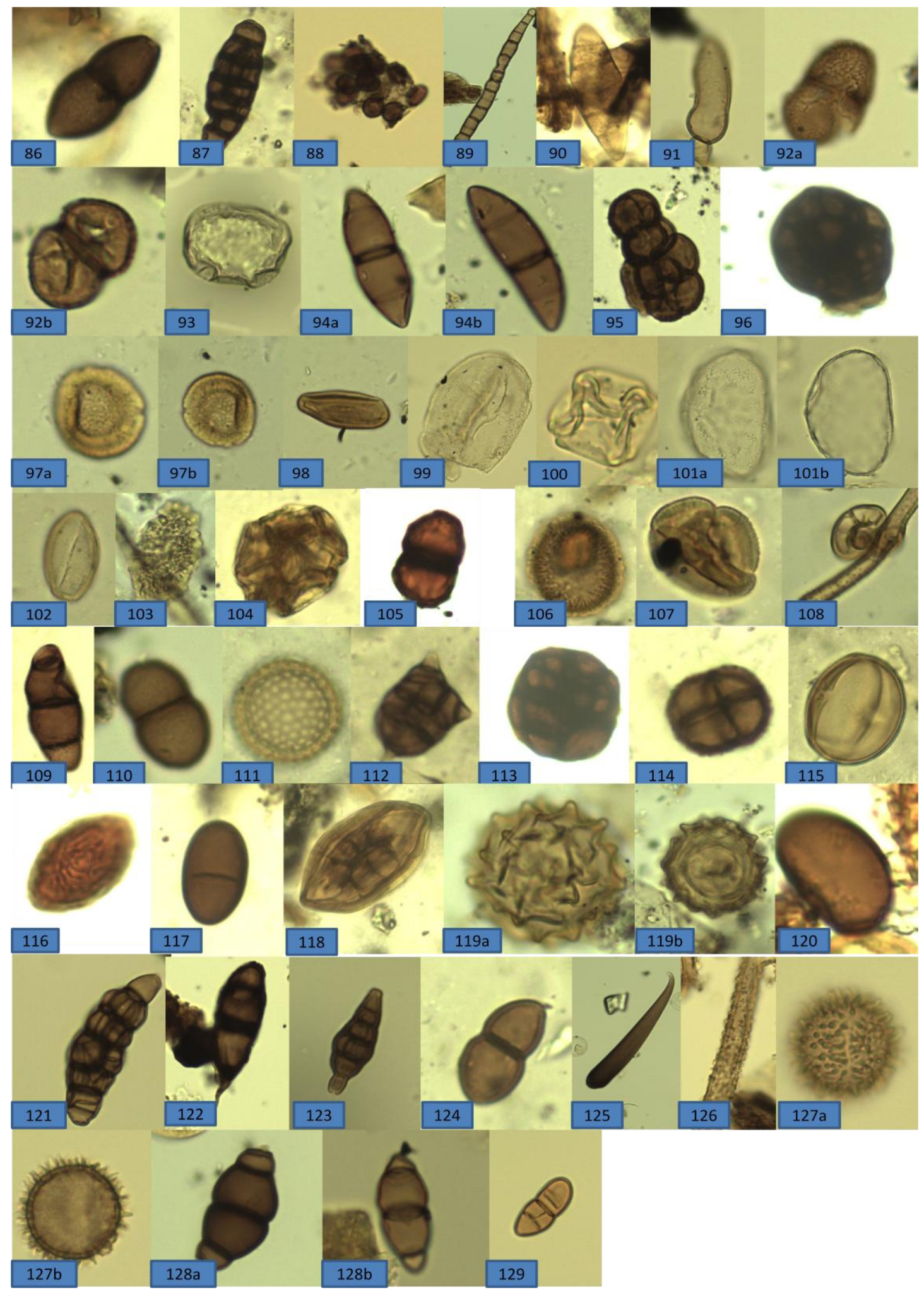




\section{APPENDIX II}

COMPLETE LIST OF POLLEN AND SPORES DIAGRAMS 


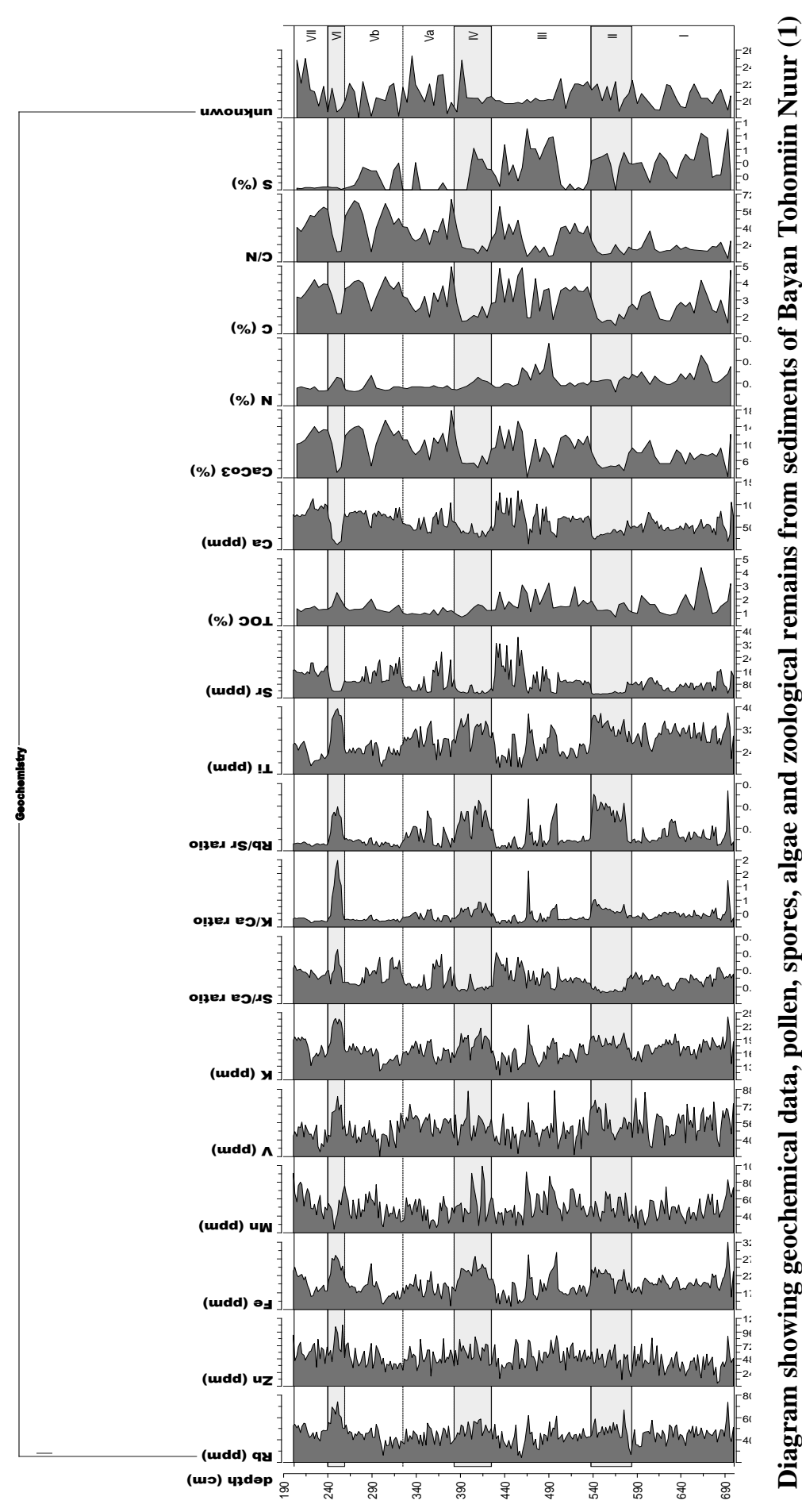




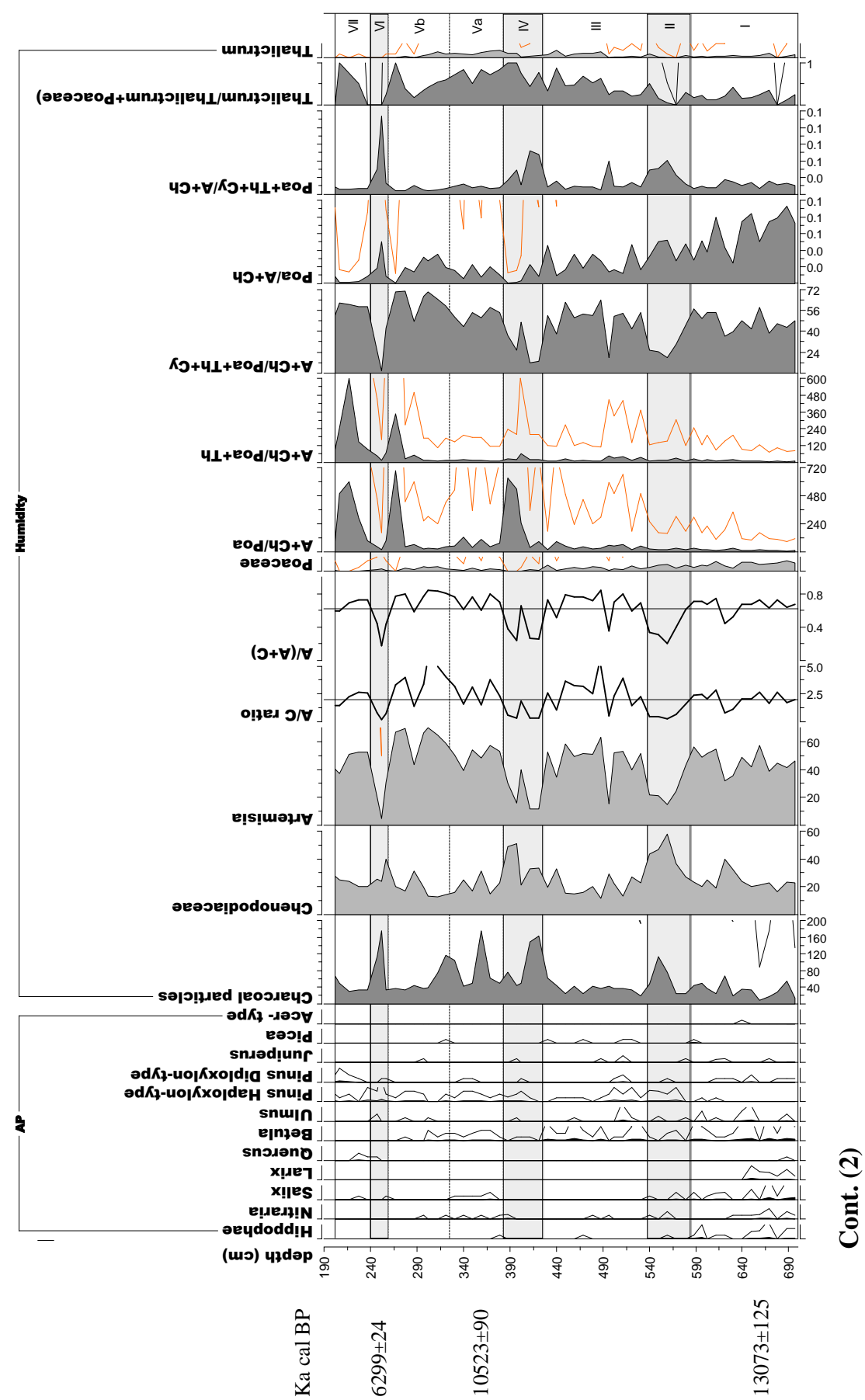




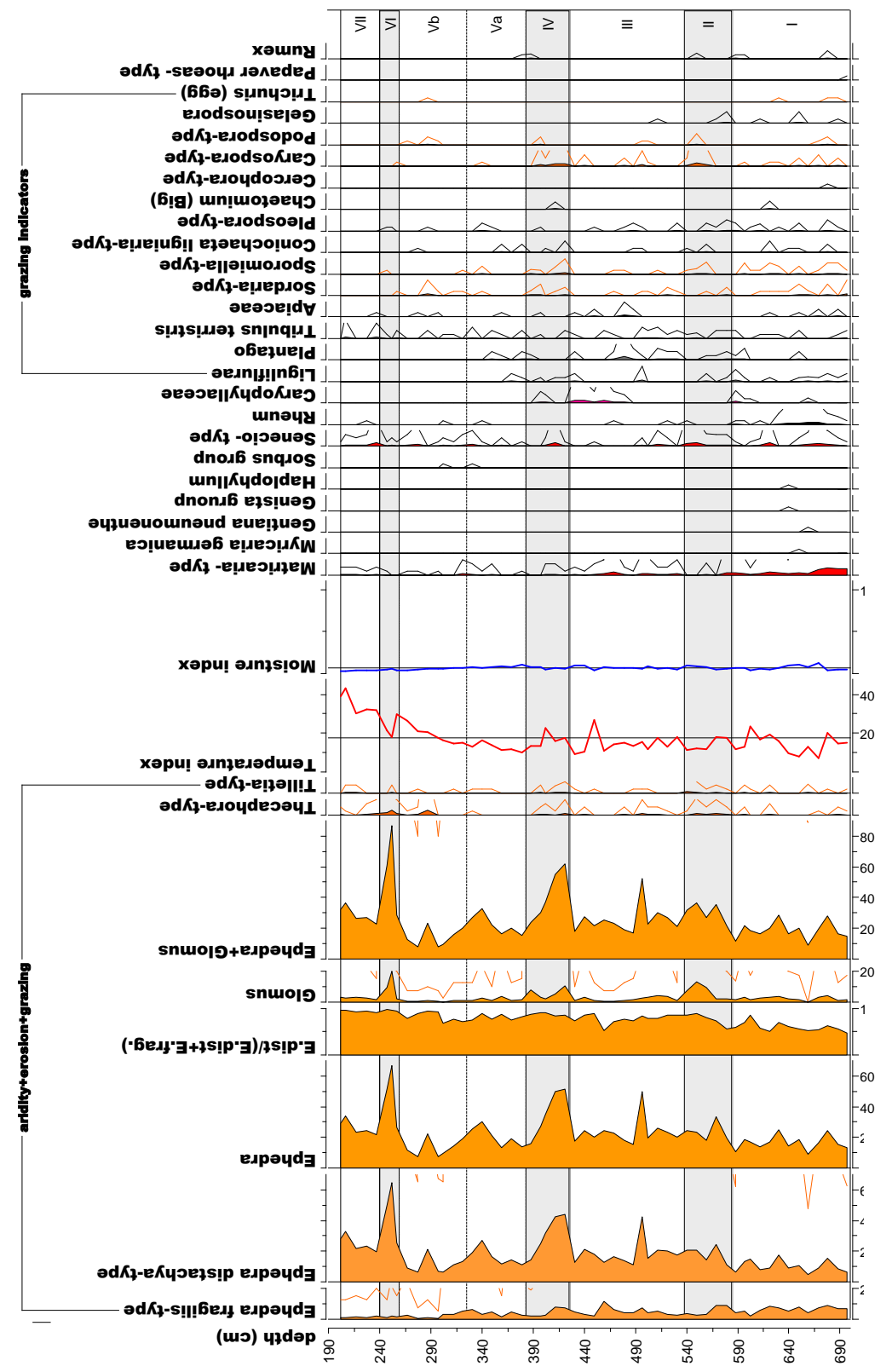

ฮิ 


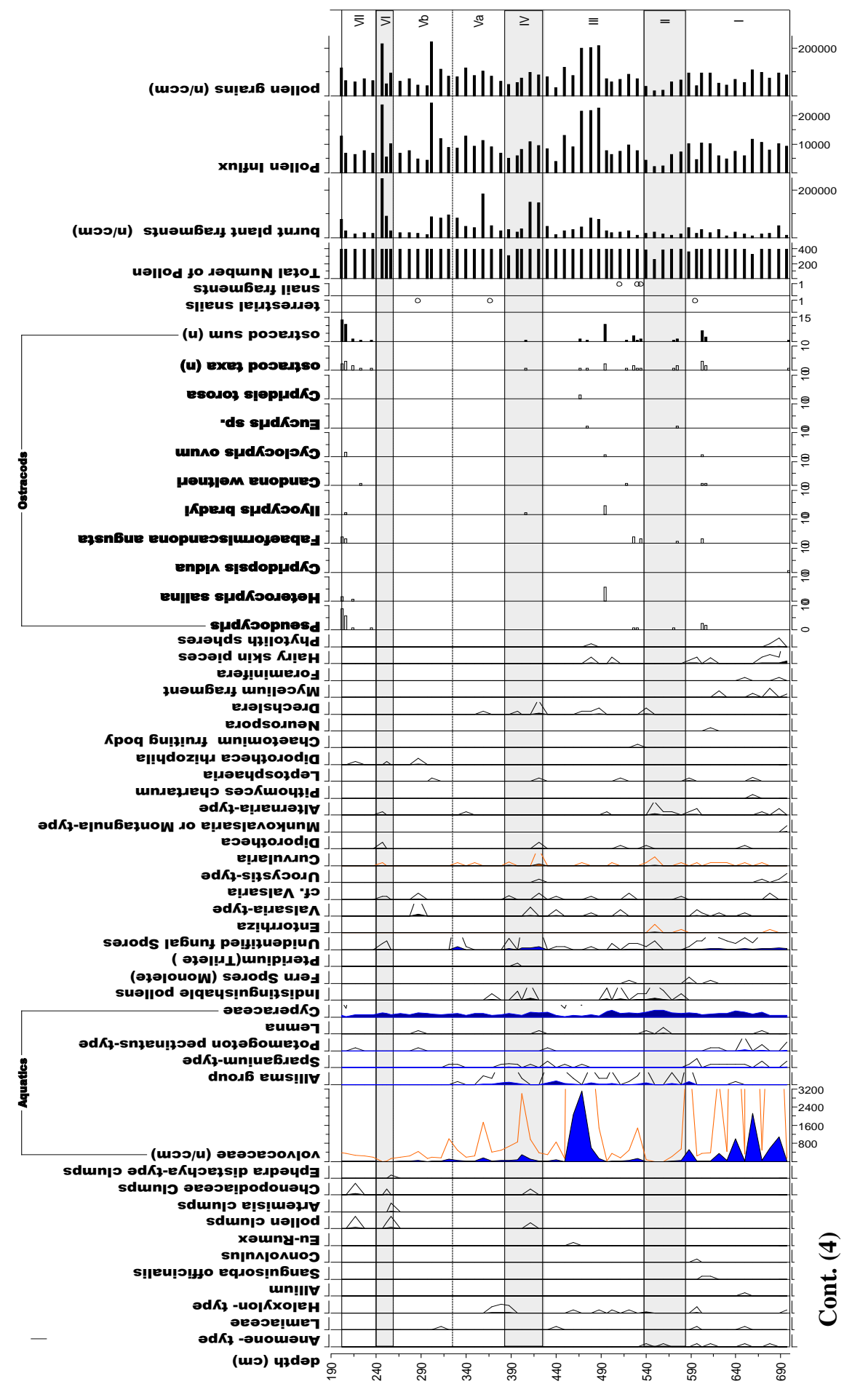




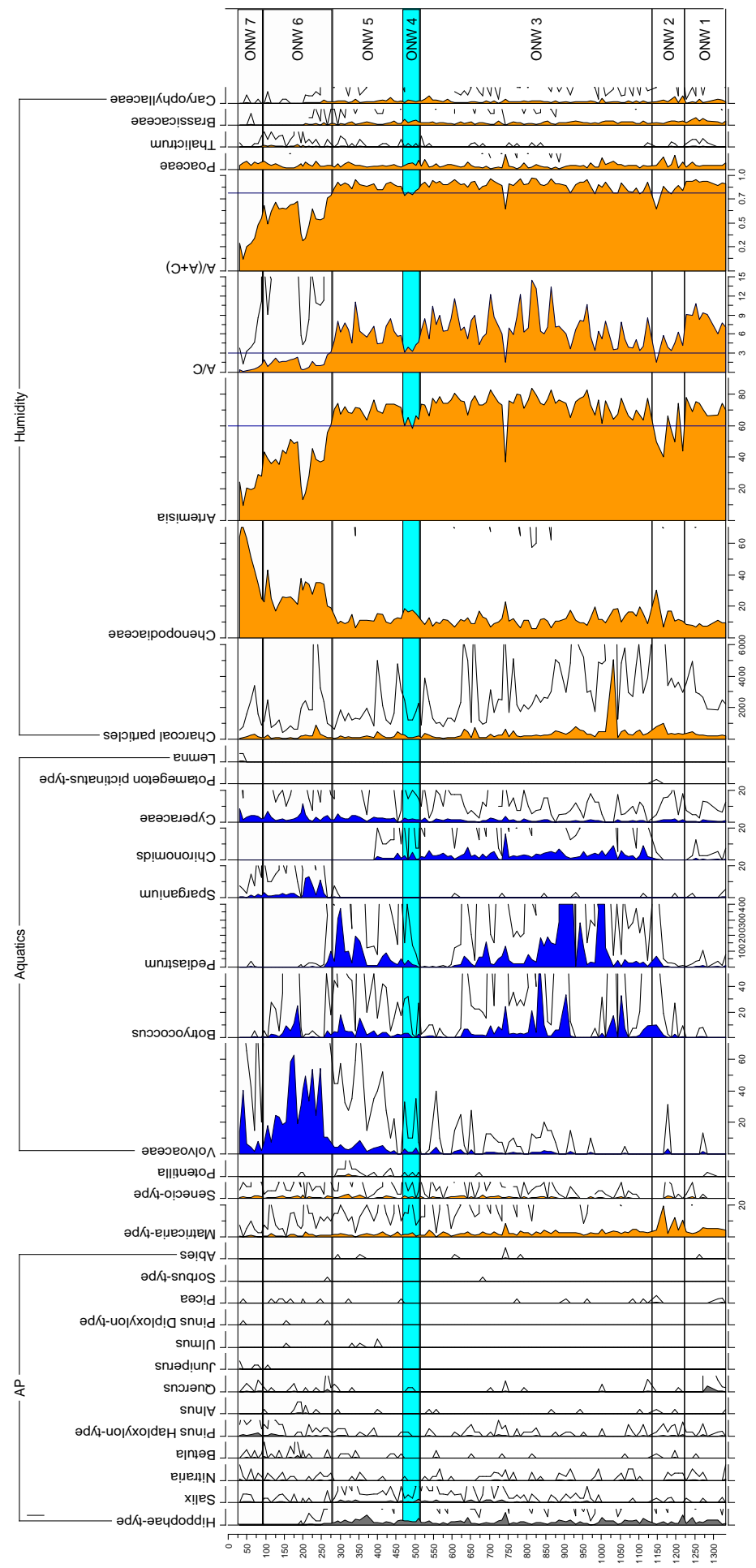

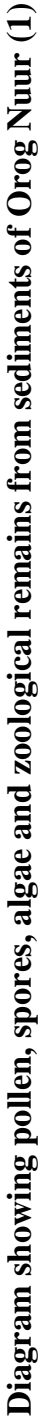




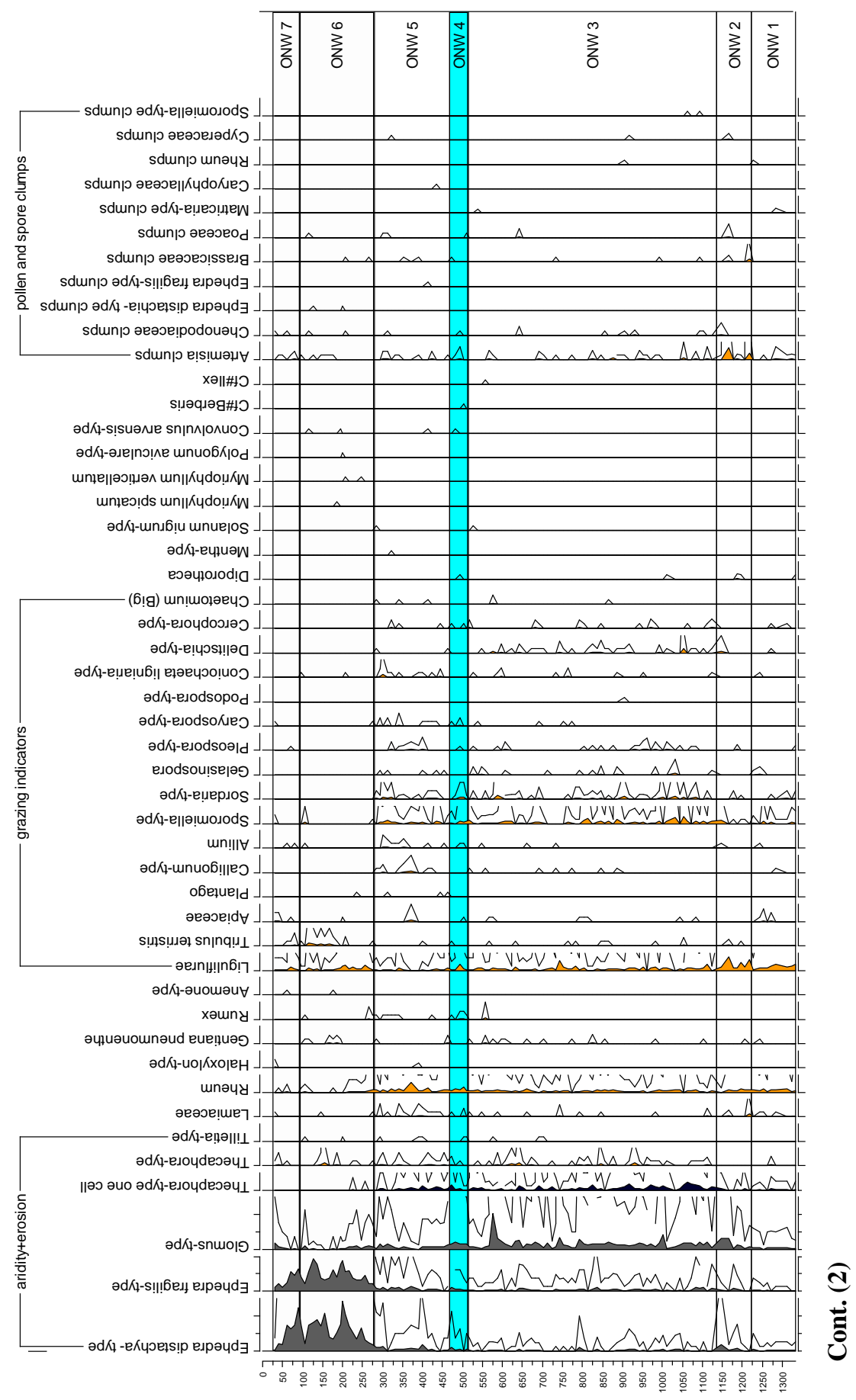




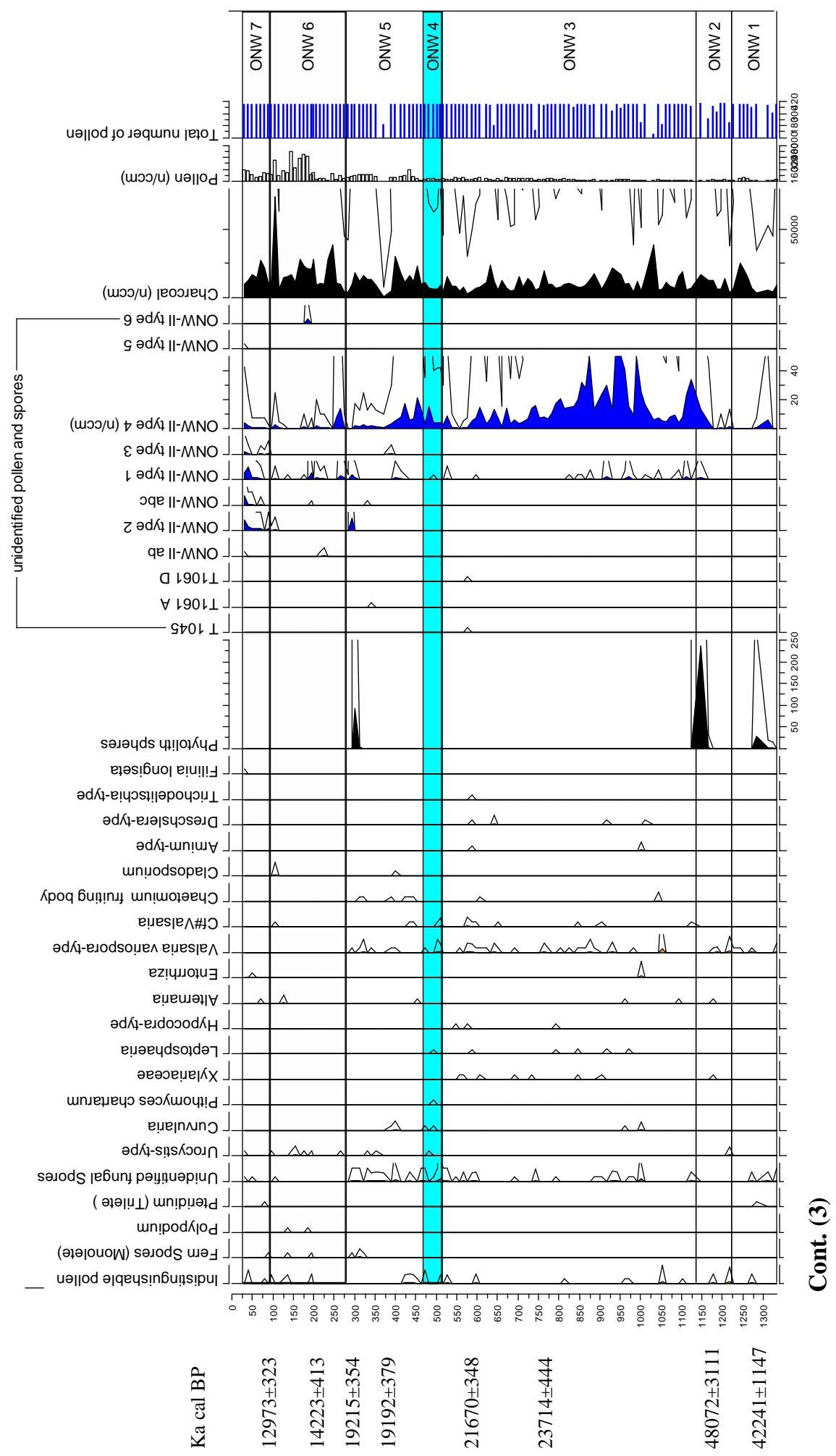




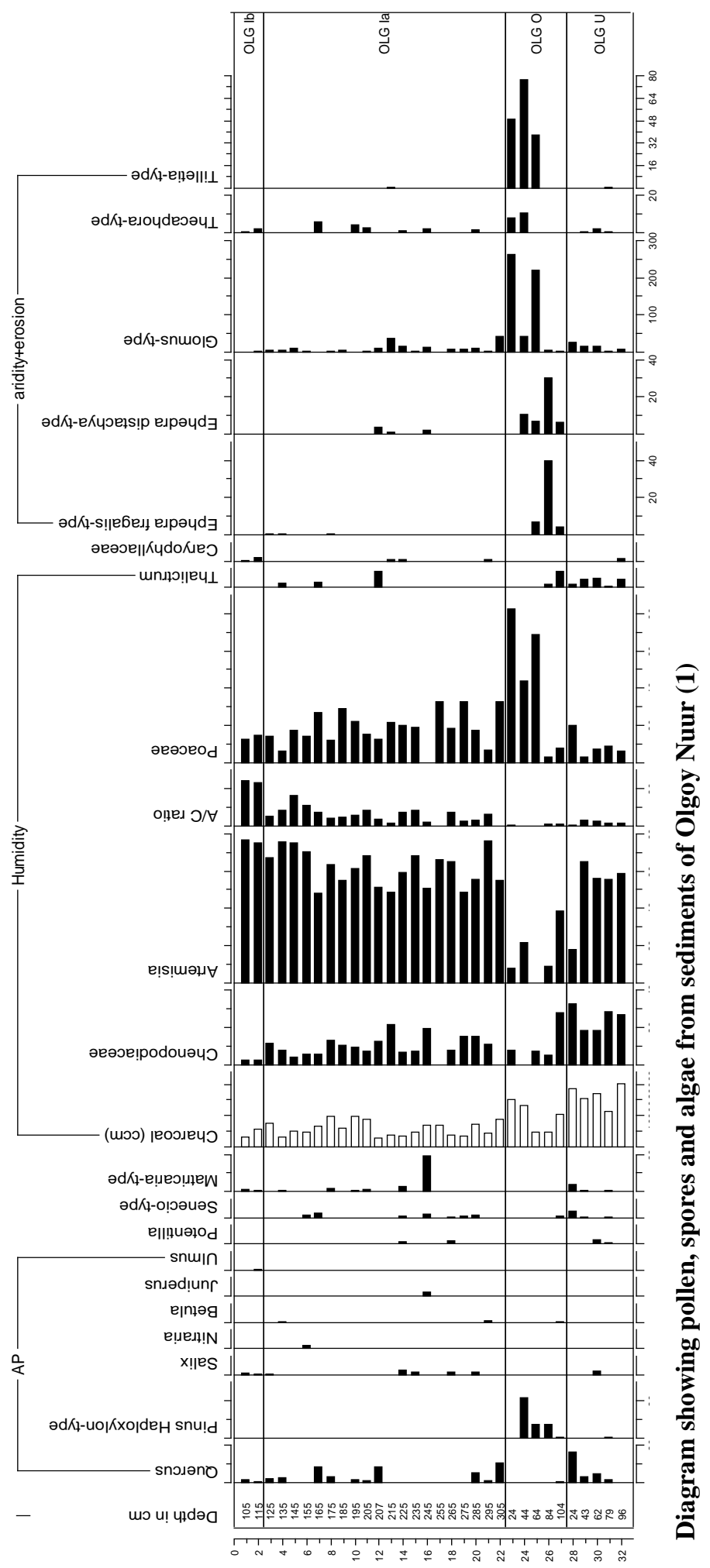




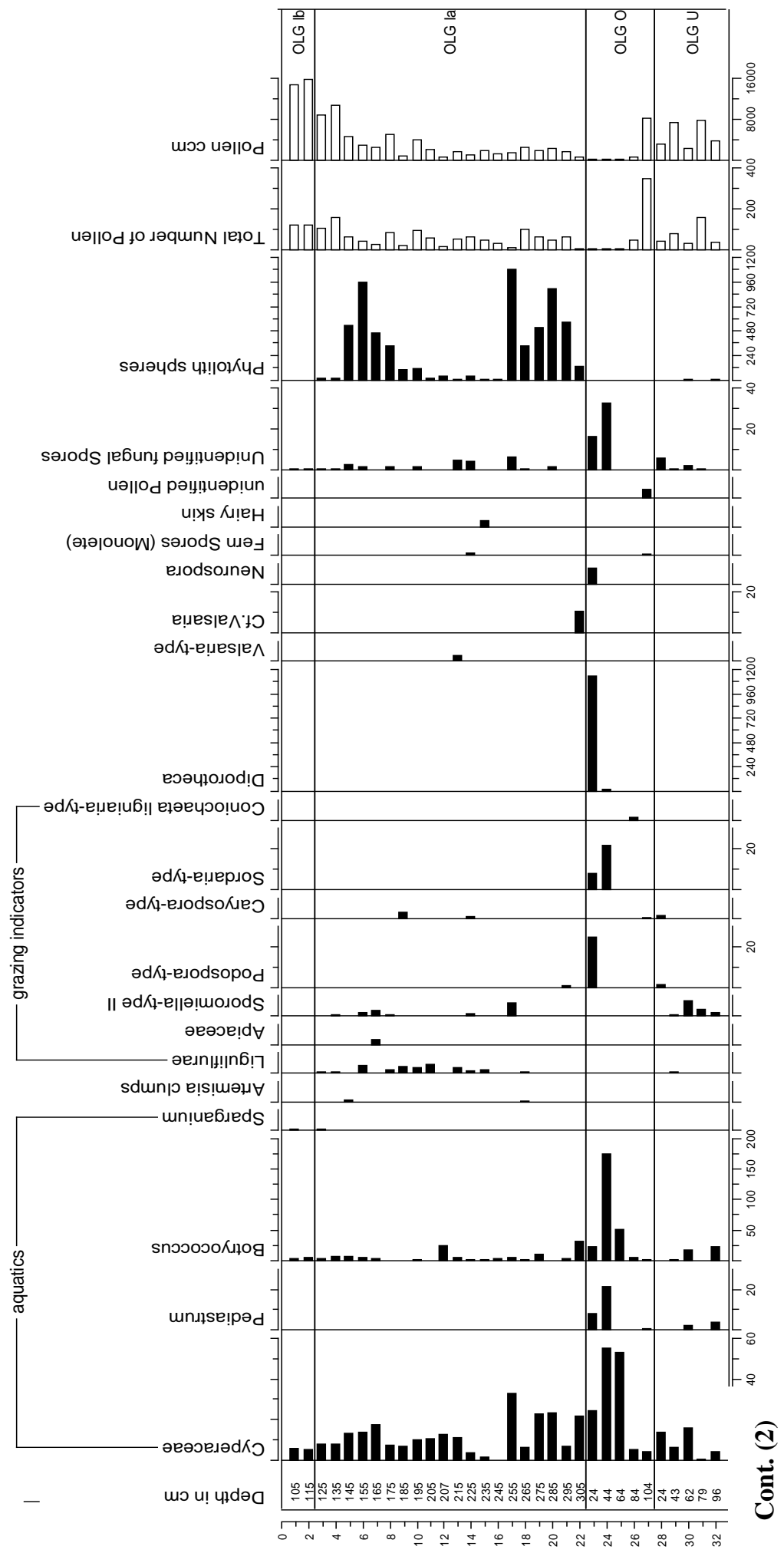

